

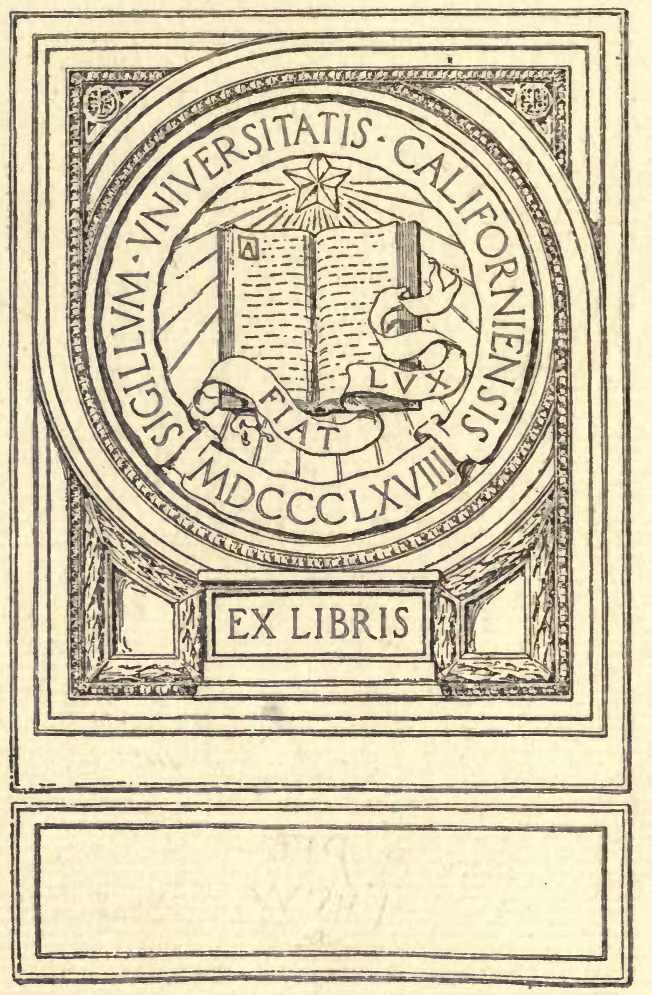



THIS EDITION IS LIMITED TO

I,200 COPIES

OF WHICH THIS IS

No. 717 




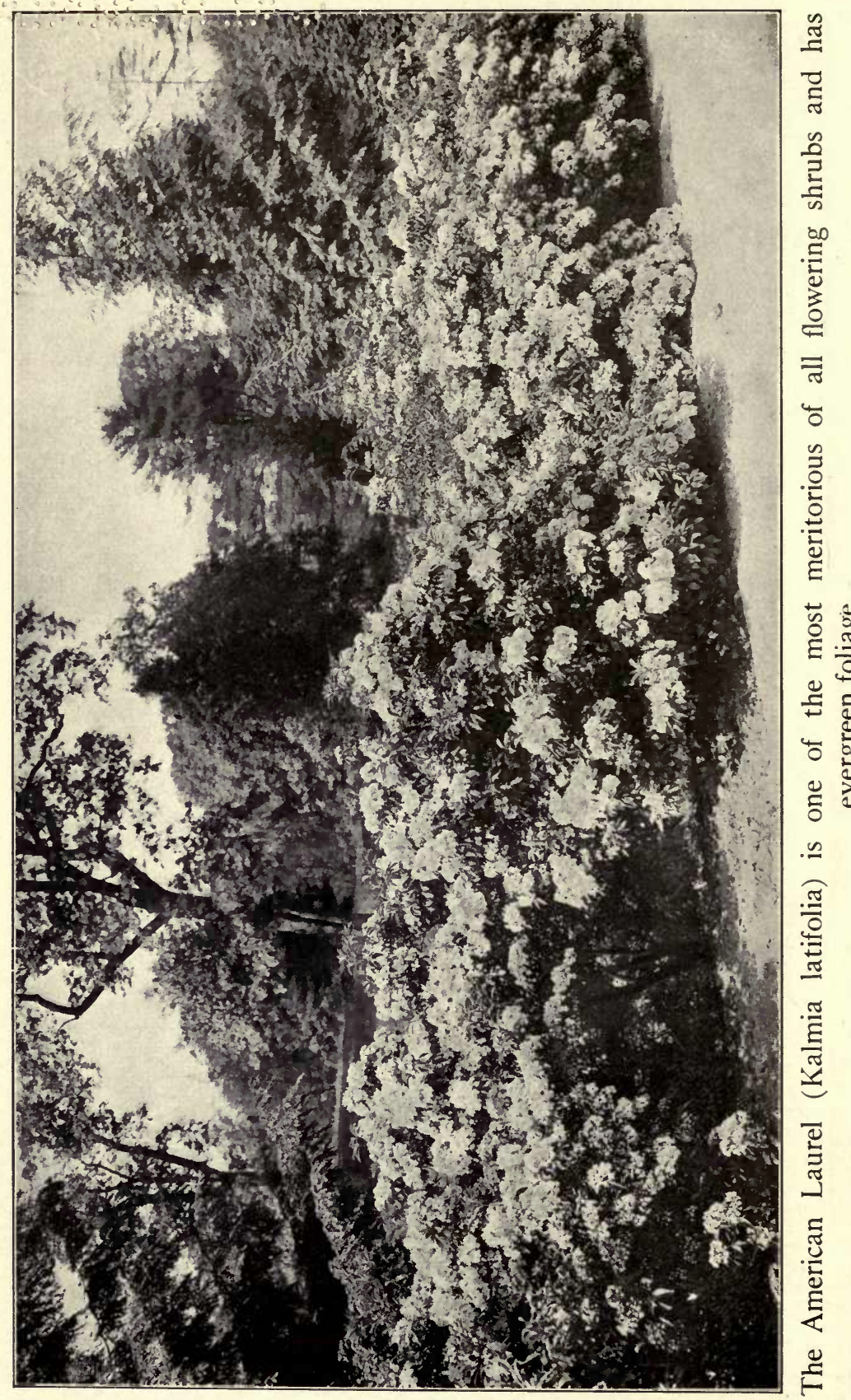




\section{ARISTOCRATS OF THE GARDEN}

BY

ERNEST H. WILSON, M.A., V.M.H. AUTHOR OF "A NATURALIST IN WESTERN CHINA"

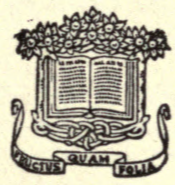

\section{ILLUSTRATED}

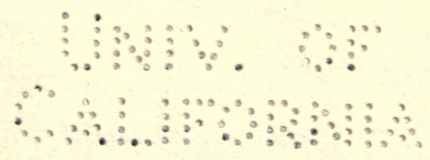

GARDEN CitY

NEW YORK DOUBLEDAY, PAGE \& COMPANY I9I7 
Copyright, 1916, 1917, by Doubleday, Page \& Company

All rights reserved, including that of translation into foreign languages, including the Scandinavian

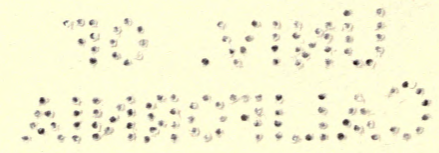




\section{CONTENTS}

I. The Story of the Modern Rose. . . 3

II. "Consider the Lilies" . . . . . 19

III. Midseason Flowering Trees and Shrubs 36

IV. The Best of the Hardy Climbing Shrubs 55

V. Ornamental Fruited Trees and Shrubs 78

VI. The Glory of the Autumn . . . . 101

VII. The Best Hardy Conifers . . . . 113

VIII. Broad-Leaved Evergreens for Northern Gardens . . . . . . . . . 138

IX. New Chinese Trees and Shrubs for the Pacific Slope and Other Favored Regions . . . . . . . . . 153

X. Early Spring-Flowering Trees and Shrubs . . . . . . . . . 175

XI. Japanese Cherries and Asiatic Crabapples . . . . . . . . . 195

XII. In "Lilacdom" . . . . . . . 213

XIII. New Herbaceous Plants from China . 230

XIV. "Hardy" Rhododendrons . . . . 244

XV. The Story of the Davidia . . . . 275

Epilogue . . . . . . . . . . 296 Index . 301 



\section{LIST OF ILLUSTRATIONS}

The American Laurel (Kalmia latifolia) is one of the most meritorious of all flowering shrubs . . . Frontispiece

FACING PAGE

The Sargent Rose, shell pink, raised at the Arnold Arboretum by Jackson Dawson . . . . . . . . . . . 3

Lilium Sargentiae has pure white flowers . . . . . . $\quad 19$

Among the later flowering trees the native American Gordonia altamaha is one of great interest . . . . . 36

Clematis montana, var. rubens is an attractive vine with rose colored flowers

The Snowberry (Symphoricarpos racemosus) is deservedly popular.

The barks of many trees have highly decorative values

As a lawn tree and for ornamental planting generally the concolor Fir is the most beautiful of conifers

101

The flowers of Yucca flaccida make this a valuable evergreen for most gardens

138

As a practical substitute for Ivy the broad-leaved, climbing Evonymus (E. radicans, var. vegetus) is an excellent evergreen vine

The Chinese Pistach Tree thrives in dry regions

The Magnolias are among the most notable spring flowering trees and shrubs

175

Why are Crabapples so little grown? They are hardy, most floriferous, and grow on almost any soil

The common Lilac is known in a great number of varieties .

Senecio clivorum has Aster-like flowers three to five inches in diameter

Primula pulverulenta has flower scapes fully a yard tall

Rhododendron caucasicum is hardy and produces in profusion its flowers of rose-red, white within

Davidia involucrata, appropriately called the Dove Tree, is indeed remarkable. 

ARISTOCRATS OF THE GARDEN 



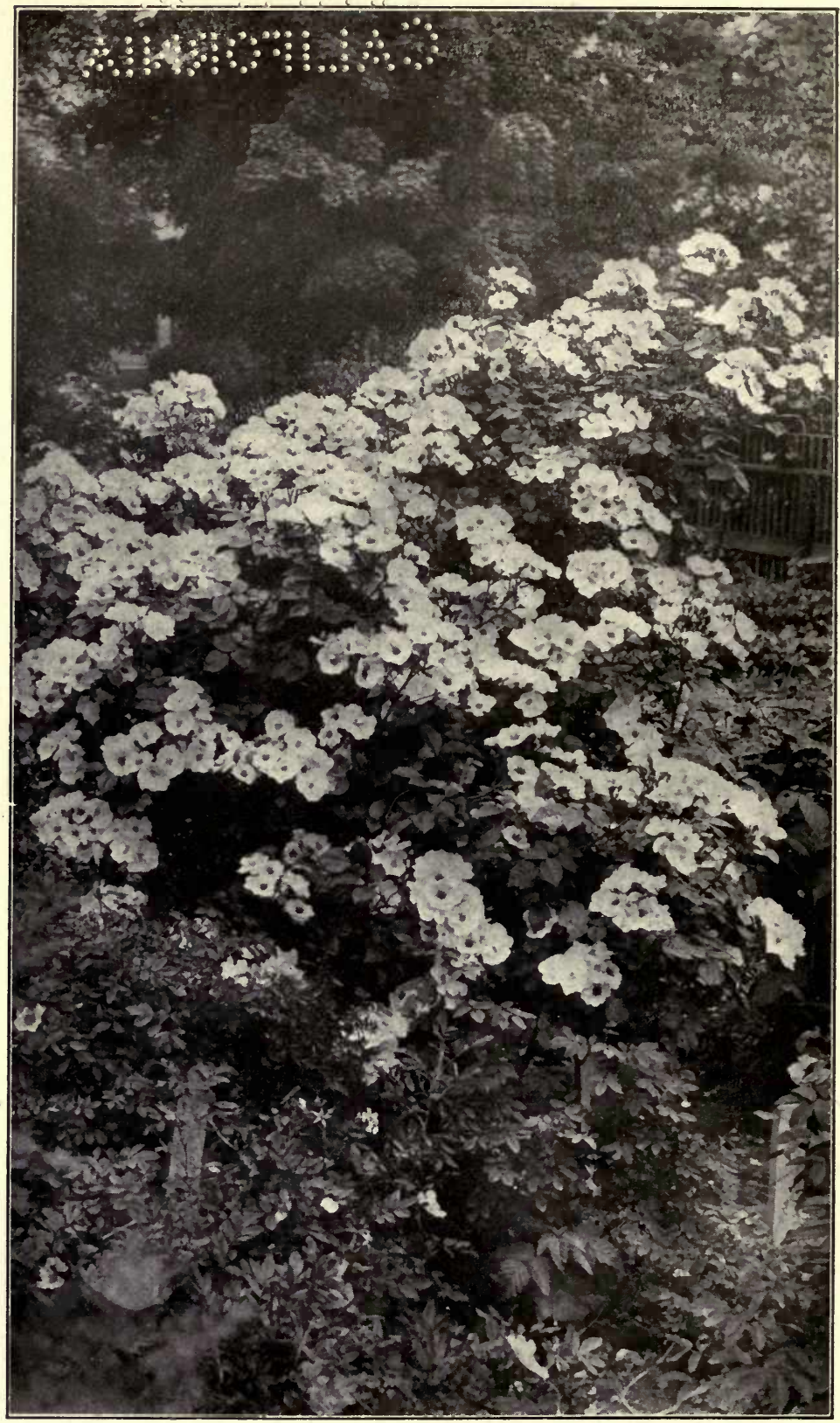

The Sargent Rose, shell pink semi-double flowers, raised at the Arnold Arboretum by Jackson Dawson, combines the qualities of Crimson Rambler and Baroness Rothschild H. P. 


\section{ARISTOCRATS OF THE GARDEN}

\section{CHAPTER I}

\section{THE STORY OF THE MODERN ROSE}

THIS UNIVERSAL FAVORITE COMING OUT OF THE EAST IS THE PRODUCT OF BUT A FEW SPECIES-LATENT POSSIBILITIES YET BEFORE THE ROSE LOVER

7 HE establishing of a trading factory at Canton, in southern China, by the English East India

Company toward the close of the seventeenth century, would appear to have very little-if, indeed, anything - to do with the development of modern horticulture in general and the Rose in particular. But as a matter of fact it has had a great deal to do with both, and garden lovers generally (though they may not know it) owe a big debt to the directors and officers of that grand old Company. The Company met with great opposition from the Chinese and others and it was a century before it fully established itself in China. Nevertheless, in the earliest days of its career there, an officer of the Company sent to England some dried plants, among them two Roses, 
known nowadays botanically as Rosa multiflora var. cathayensis and $R$. laevigata, and these were mentioned by Plukenet in his Almagestum in 1696 . Toward the end of the eighteenth century, despite the Napoleonic wars and the fact that each vessel was armed and often had to do battle against foes, the captains of the EastIndiamen, as the Company's ships were called, used to carry home plants which they, or the factory officials at Canton, found growing in the gardens of the Chinese.

These plants found their way into the gardens of the Company's directors and their friends and from hence into the Royal Gardens, Kew, and elsewhere. To these agencies we owe our earliest varieties of Chrysanthemums, Camellias, Moutan Peonies, China Primrose, China Azaleas, and, what here concerns us chiefly, the first plants of the China Monthly, Tea, and Rambler Roses-parents of the modern Rose.

Early in the eighteenth century India received through the same source many plants including these and other Roses. It is important to remember this since one of these, the China Monthly Rose (Rosa chinensis), was afterward erroneously considered to be native of India and became generally known as the Bengal Rose. This Rose and its var. semperflorens were introduced by the French into the Isle of 
Bourbon, doubtless from India, during the eighteenth century.

The Bengal Rose was known to Gronovius in 1704, and came into cultivation in Haarlem in 1781, having probably been introduced by Dutch East-Indiamen. But, preoccupied with their Tulips and other bulbous plants the Dutch have done little toward developing the modern Rose. In 1789, Sir Joseph Banks introduced it into England and, chronologically, our story here begins.

In 1789, the Crimson China Monthly (Rosa chinensis, var. semperflorens), through the captain of an English East-Indiaman, came into the possession of Gilbert Slater, Esq. In 1804, Thomas Evans sent from China to England through the same agency the first Rambler Rose (Rosa multiflora, var. carnea). In 1809, Sir Abraham Hume received from China through a similar agency the first Tea-scented Rose, which had double pink flowers and was christened Rosa odorata. And, to complete the independent activities of the English East India Company, between 1815 and 1817 Charles Francis Greville, Esq., received from China a Rambler Rose (Rosa multiflora, var. platyphylla) which enjoyed lasting popularity under the name of Seven Sisters and by which name it will be remembered by many readers of these pages. 
Meanwhile, in 1792, Lord Macartney brought back with him from China a Rose $(R$. bracteata) which was styled the Macartney Rose and which is now naturalized in some of our warmer states.

Another Chinese Rose-the Cherokee Rose-the date of whose introduction into this country is unknown, is also naturalized widely in the warmer states and received its earliest name ( $R$. laevigata) in 1803, from Michaux who firmly believed it to be native of this country.

In 1796, Rosa rugosa, native of Japan, Korea, and extreme northeastern Asia, was introduced into England by Messrs. Lee and Kennedy.

These new and amazing plants from China quickly attracted the attention of patrons of horticulture in England and men were despatched to China expressly to send home all the novelties they could find; and, intermittently, from the commencement of the nineteenth century down to the present day, ardent collectors have been busily employed, but this wonderfully rich country is not yet exhausted of its floral treasures! One of the first of these collectors-William Kerr-sent home in 1807 the double whiteflowered Banksian Rose (Rosa Banksiae). In 1824, John Damper Parks sent home the double yellowflowered Banksian Rose (R. Banksiae, var. lutea) and 
a semi-double yellowish Tea Rose ( $R$. odorata, var. ochroleuca). In 1825, the Small-leaved Rose ( $R$. Roxburghii, better known as $R$. microphylla) with double reddish flowers blossomed for the first time in Messrs. Colville's Nursery in London.

We have already mentioned that China Roses were introduced into India in the eighteenth century and that some of them toward the end of that century were introduced into the French Isle of Bourbon, south of the equator, where we learn they thrived amazingly and produced new forms.

From Mauritius in 1810, Sweet introduced into England the Fairy Rose ( $R$. chinensis, var. minima); this I consider to be merely a variant of var. semperflorens, the Crimson Monthly Rose. About 1819, from the Isle of Bourbon, the Rose Edward reached France, and, crossed with the French Rose ( $R$. gallica), gave rise to the Hybrid Bourbon Roses. This Rose Edward is of much interest; long ago it was cultivated in Calcutta and it is obviously a Hybrid China. The specimen I have seen strongly suggests $R$. chinensis $\times R$. centifolia as its parentage.

The China Monthly Rose ( $R$. chinensis) crossed with the French Rose ( $R$. gallica) gave rise to the Hybrid China Roses. The Hybrid China and the Hybrid Bourbon crossed with the Damask Rose ( $R$. 
damascena) gave rise to the Hybrid Perpetual or Remontant Roses. The Hybrid Perpetual crossed with the Tea Rose ( $R$. odorata) gave rise to the Hybrid Tea Roses which to-day are the dominant class of Roses. Lastly, Rosa chinensis crossed with the Musk Rose (R. moschata) gave rise to the Noisette Roses, a beautiful class which, unfortunately, has gone out of favor.

But to return to the collectors: In 1846, Robert Fortune sent from China to England the yellow-buff Fortune Rose ( $R$. odorata, var. pseudoindica), a Teascented Rose rather similar to the var. ochroleuca and widely known under the name "Beauty of Glazenwood." In 1850, he sent home from China a Rose with relatively large double white flowers supposed to be a cross between the Banksian and Cherokee Roses and which was named Rosa Fortuneana. In 1886, the Wichuraiana Rose (R. Luciae) was introduced into Brussels from Japan. In 1878, Prof. R. Smith sent from Japan to a Mr. Jenner in England a Rose which the recipient named The Engineer in compliment to the profession of its donor. In course of time this Rose came into possession of a nurseryman named Gilbert who exhibited some cut flowers of it under the above name in 1890 , and received an Award of Merit from the Royal Horticultural Soci- 
ety. Soon afterward Messrs. Chas. Turner, of Slough, purchased the stock and changed the name to Crimson Rambler. This Rose is generally assumed to be a hybrid between Rosa multiflora and some China Monthly Rose, but to me this view is untenable. I do not think it has any China Monthly blood in it at all. It has long been cultivated in China and I consider that, like the Seven Sisters Rose, it is a sport from the common, wild pink-flowered China Rambler ( $R$. multiflora, var. cathayensis). These various Chinese Roses were introduced from Chinese gardens where they have been cultivated from time immemorial and their wild prototypes were not discovered, much less introduced, until comparatively recently.

The true Rambler Rose ( $R$. multiflora) is a native of Japan and has single white flowers in large panicles. This was sent to Lyons, France, from Japan in 1862, by Monsieur Coignet, an engineer. The pink-flowered Chinese variety has only just been dignified by a distinctive name. In 1888, General Collett discovered, in the Shan Hills of Upper Burmah, a Rose with white, pale yellow, or buff flowers six inches across and this was named Rosa gigantea. He introduced it into Europe and it thrives wonderfully on the Riviera but in England it flowers sparingly. This 
Rose is common in Yunnan, southwest China, and has given rise to a race of double-flowered Roses which are cultivated for ornament by the Chinese in that region. This Giant Rose is very fragrant and I believe it to be the prototype and parent of the Teascented Roses so long cultivated by the Chinese. The prototype of the China Monthly Rose (Rosa chinensis, var. spontanea) was first found growing wild in 1885 , by A. Henry, in the province of Hupeh, central China, and in this same region the wild form of the Banksian Rose with single white flowers is extraordinarily abundant; so also is the Cherokee Rose; and further west, in Szechuan, the prototype of the Small-leaved Rose (R. Roxburghii) is one of the most common wayside shrubs.

The genus Rosa is confined to the Northern Hemisphere and its members are found scattered over the cool and warm temperate and the sub-tropic regions of Asia, Europe, and North America. Some of them are found in northern Africa but no species is endemic there. It is an exceedingly difficult genus to classify and botanists differ greatly in the estimate of the number of species. One botanist asserts that all may be included under three species; in the Index Kewensis more than five hundred species are enumerated. In the Arnold Arboretum Herbarium twenty- 
six species are recognized as indigenous in North America; and of these virtually only one ( $R$. setigera), the Prairie Rose, has been utilized by the hybridist to date, and this but sparingly. However, it is well to mention that a double-flowered form of Rosa virginiana, the Rose d'Amour, has been known since 1768, and quite recently Rosa humilis has been crossed with Rosa rugosa.

Except in gardens devoted to forming collections of plants, species of Rose, with a few exceptions, are rarely cultivated and it is trite to say that Roses as ordinarily understood are "made," not discovered wild. In other words, they are the product of the gardeners' skill. I would I could take the readers of this work to the mountain fastnesses of central and western China, and to certain remote parts of Japan and there introduce him to the wild types - the raw material-from which have been evolved our "Killarneys," "American Beauty," "Mrs. Chas. Russell," "Lady Hillingdon," "Caroline Testout," "Mrs. George Shawyer"; our "Rambler" and "Wichuraiana" hybrids and innumerable others, and his or her astonishment would be profound. Truly it hardly seems credible that the Roses of to-day had such lowly origins.

The French Rose ( $R$. gallica), Provence Rose 
( $R$. provincialis), and Cabbage Rose ( $R$. centifolia) are said to be the only Roses known to Pliny, and it must be confessed that the distinctions between these socalled species are not obvious. From earliest times in the Occident, down to the end of the eighteenth century, the Roses so much extolled by ancient writers and by our ancestors were either wild species native of Persia, Asia Minor, and Europe, or garden forms derived therefrom. These would include, in addition to those aforementioned, the White Rose ( $R$. alba), the Musk Rose ( $R$. moschata), the Damask Rose ( $R$. damascena), the Cinnamon Rose ( $R$. cinnamomea), the Moss Rose (R. centifolia, var. muscosa), Sweet Briar ( $R$. eglanteria), Sulphur Rose ( $R$. hemisphaerica), Austrian Briar (R. foetida), and the Austrian Copper ( $R$. foetida, var. bicolor).

About the end of the eighteenth century the Ayrshire Roses were originated from $R$. arvensis, and early in the nineteenth century the Boursault Roses were developed, through crossing the Alpine Rose (R. pendulina) with $R$. chinensis, and the Scotch Briars from $R$. spinosissima. Virtually all have disappeared from general cultivation in the gardens of Europe and North America. And all the species of Rose indigenous in North America, Europe, and Asia Minor have fallen into disfavor and are no longer used 
by the Rose hybridist with the exception of those which have yellow flowers.

In Bulgaria and other parts of the Balkan Peninsula, and on a small scale in parts of India, the French, Cabbage, and Damask Roses are extensively cultivated for the preparation of Attar of Roses. But as garden Roses the old have given place to the new, and the gardens of to-day are resplendent with the products of the China, Tea, Rambler, and Wichuraiana Roses, natives of China and Japan.

New garden Roses are originated by the hybridizing of different species, varieties, and forms, and as sports from existing forms as in the case of "White Killarney" and many others. They are raised by means of seeds, cuttings, layering, budding, and grafting, but it is no part of my purpose to enter into these details. The object here is to tell of what has been, to show the source of what is, and to hint of what may yet be evolved.

Of the vast array of Rose species not more than two dozen have in the past history of the Rose been employed in the breeding of garden Roses. Thus, leaving completely aside the innate tendency to variation on the part of Roses of to-day, it is obvious that Rose breeders and specialists have still a wide untrodden field in which to experiment. It cannot 
be expected that every species will be found useful in the advancement of the Rose, yet at the same time only experiment, long continued, can decide which are useful or useless. Be it remembered that our present-day Roses owe their principal origin to forms cultivated, we know not how long, by the flowerloving Chinese. The prototypes of the China and Tea Roses have single flowers, and blossom but once a year. When these forms gave rise to "monthly blooming" Roses, or how the latter originated is unknown. Possibly, it was some erratic sport or maybe it was due to a radical change in environment caused by the removal of the parent plants to a region where the seasons were less fixed or winter unknown. However, be this as it may, a Rose with a decided tendency toward perpetual blooming was the most marked advance in the genus, from a garden viewpoint, that had occurred up to that time. How modern hybridists have taken advantage of this variation needs no comment.

All Rose breeders have their ideals, but in striving after size, form, color, freedom of blossom and of habit, after good foliage, hardiness, constitution, keeping qualities of the flowers and the like, fragrance should not be lost sight of. We want Roses good in all points. We want fragrant Roses in increasing 
quantities. We want a Rambler Rose with purewhite flowers as large and as freely produced as in the Crimson Rambler. Also we want yellow Ramblers, yellow Hybrid Perpetuals, more yellow Hybrid Teas and Tea Roses.

Where can we look for these yellow Roses? Now, of wild Roses with clear yellow flowers there are only known six species: the Simple-leaved Rose ( $R$. persica), Austrian Briar (R. foetida), Sulphur Rose (R. hemisphaerica), Mrs. Aitchison's Rose (R. Ecae) -all natives of Asia Minor and Persia to central Asia (Austrian Briar is also found in the Crimea)Father Hugh's Rose (R. Hugonis), and Lindley's Rose (R. xanthina) natives of northern China. The latter, though named in 1820 from a Chinese drawing and long cultivated in Peking where double and singleflowered forms occur, was only introduced to cultivation in April, 1908, by F. N. Meyer of the U. S. Department of Agriculture. Father Hugh's Rose was raised at Kew in 1899. The others have been known for a long period and some have been and still are being used by Rose breeders. The Double Sulphur or Yellow Provence Rose has been known since the seventeenth century. The Yellow Persian was brought from Persia in 1838, by Sir Henry Willock, and is presumably a form of $R$. foetida. The 
Harison Rose is either a form of this or more probably a hybrid between it and $R$. spinosissima. All these Roses will doubtless play an important part in the future, but, personally, I am of the opinion that the yellow and buff-colored forms of Rosa odorata, var. gigantea are the Roses that will be found of greatest value in the evolution of the yellow Roses of the future. The rampant growth and sparseness of blossom may be urged against them, but who can say how much these characters may be modified under cultivation and by the hybridist? Forms of the Scotch Rose ( $R$. spinosissima) have nearly yellow flowers, but the only other really yellow Roses known are $R$. Banksiae, var. lutea and the single-flowered $R$. Banksiae, var. lutescens, neither yet known in a wild state.

Wild Roses are pretty and charming plants, yet it cannot be claimed that their beauty transcends that of other groups of wild flowers. Nevertheless, the Rose holds a unique place in the thought and estimation of civilized man. In poetry and prose its beauty has been extolled far and wide in many tongues. The old Persian poet, Omar Khayyam, in the eleventh century, sang its praises and a Damask Rose now grows on his grave and also on that of his first English translator, Edward Fitzgerald. 
The Rose is the one flower whose name is common to the polyglot people of this land. In English, French, German, Danish, and Norwegian its name is Rose; in Italian, Spanish, Portuguese, Russian, and Latin it is Rosa; in Swedish it is Ros, in Dutch Roos, in Bohemian Ruze, in Hungarian Rozsa and in Greek Rhodon. Is not this both remarkable and significant? It is the national flower of one great race, but it is loved by all and is the monopoly of no one race nor creed. In one internecine war it was used as an emblem by opposing factions. In this country's Civil War the Cherokee Rose was often planted as a memorial on the graves of fallen heroes by their surviving comrades. And to-day, the sight of the white flowers of this Rose wells up from the heart of many a veteran scenes of carnage and strife and brings back memories of comrades laid to rest beneath its shade.

In this and other lands the Rose has societies devoted to encouraging its advancement, and rightly so. But in some ways the Rose of al flowers least needs the help of special societies. It is the one flower which for some inscrutable reason has never lost its popularity and by this same token never will.

The story of the Modern Rose is a story of progress and as such holds a peculiar fascination over all. 
The Near East gave the first fruits to the West; the Far East in due course added its bounty. Europe began the improvement, and soon this country took up a share. The peoples of Asia, Europe, and North America have evolved the Modern Rose. With the rapid advance in the science of hybridizing and the introduction of species and forms from far and near new races will be evolved and new eras in the development of the Rose will arise. The story here briefly sketched is but the prelude to the full story of the Rose which the future will gradually unfold. 


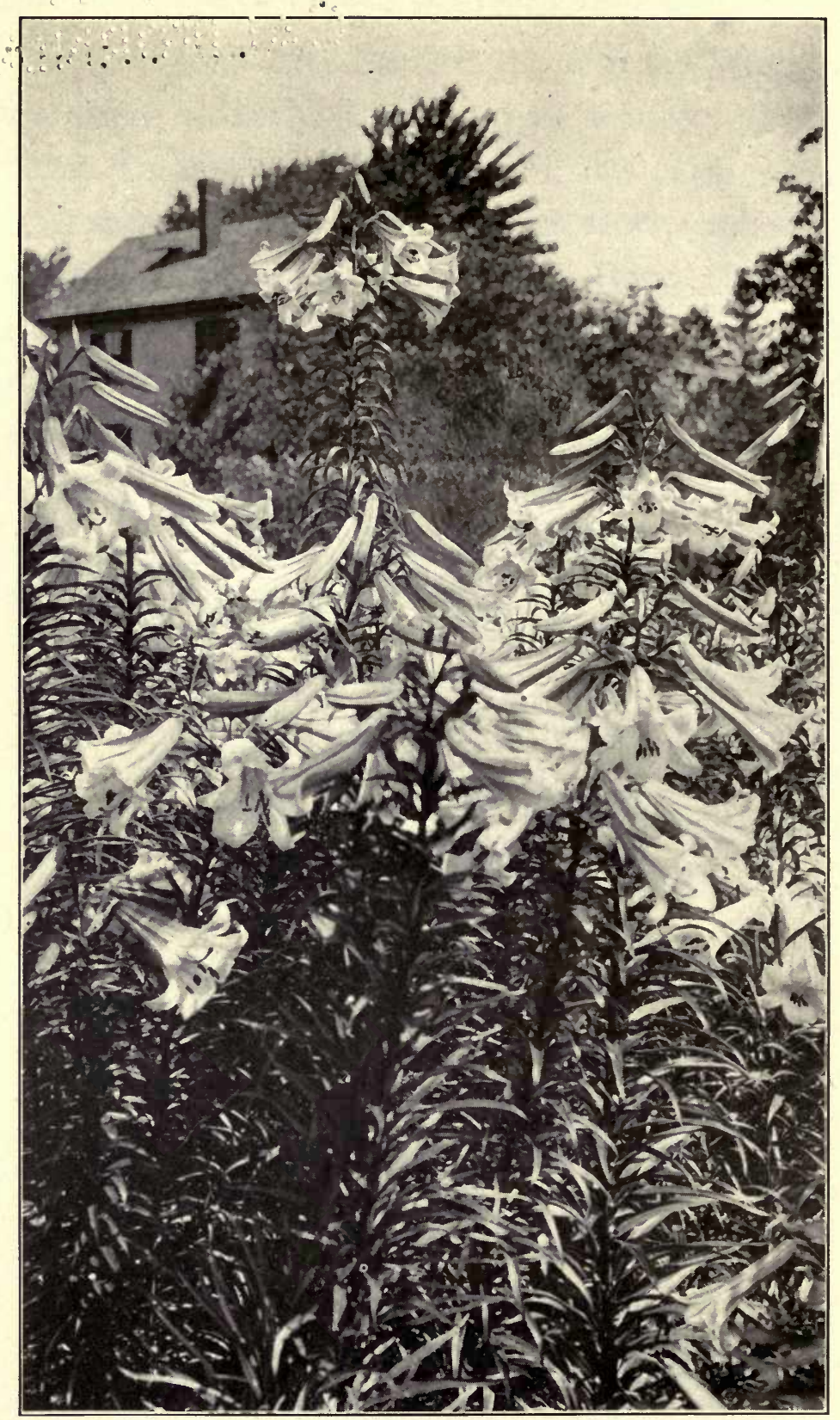

Lilium Sargentiae has pure white flowers and is quite hardy in Northern gardens 


\section{CHAPTER II \\ "CONSIDER THE LILIES"}

COMMON ERRORS OF BELIEF IN THE REQUIREMENTS OF THESE SUPERB FLOWERS-A DOZEN SPECIES THAT ARE REALLY HARDY

$\mathbf{I}$

$\mathrm{N}$ A recipe for jugged hare some one once made the sage remark "First catch your hare!" This Lilies it may be altered to "First secure healthy bulbs." In the matter of the hare every epicure cannot go forth with dog and gun and hunt his game; neither can every lover of the Lily journey forth to distant regions and dig a stock of bulbs. Both, perforce, must resort to the dealer and depend upon his knowledge and honesty, or on their own judgment.

As one who has hunted the Lily on cliff and dale, on mountain-slope and alpine moorland, and through woodland and swamp in many remote parts of China and the Thibetan borderland, and from the extreme south of Japan northward through that pretty country to Saghalien and the lonely shores of the Okhotsk Sea, I propose here to consider, cursorily, how Lilies grow. No class of herbs is more widely 
known or more highly appreciated; on no class of plants is more money annually spent (I had almost written wasted); and with no class of flowers do amateurs succeed less. The Lily growers who have achieved outstanding success can be counted on one's fingers, and nurserymen have failed as completely as have amateurs.

Some species, like the Tiger Lily (L. tigrinum,) succeed almost everywhere and often under the most unfavorable conditions. Others, like the Madonna Lily (L. candidum), thrive amazingly in unexpected places where they receive no thought or attention. The Madonna Lily is the glory and pride of many a cottager's garden in the south of England yet often on the "squire's estate" near by neither skill nor care can induce it to happily make itself at home. David Harum opined that "a reasonable amount of fleas is good for a dog-they keep him from brooding on being a dog." How far the Lily enthusiast can apply this philosophy to his own particular troubles depends upon the individual and is very much a moot point.

However, a good many of these troubles are directly or indirectly of his own seeking although he may be quite unconscious of the fact. It would be absurdly fallacious to contend that with knowledge and care every Lily-lover can successfully cultivate any kind 
of Lily that pleased his fancy, but knowledge and care will teach what particular kinds can successfully be grown and in time convince the enthusiast that he must be content with a limited number. Such knowledge may be of slow growth and painfully acquired but such we value most.

Now, in passing, let us devote a few moments to considering the noblest of all the Lilies-L. auratum, the "Golden-rayed Lily of Japan." How many millions of bulbs of this Lily have been imported; how many thousands of purchasers have been disappointed; how many letters protesting, or seeking advice, have been penned? This wonderful Lily flowered first in this country in 1862 , in the garden of Francis Parkman, the historian, at Jamaica Plain, Mass., having been received from Japan through Mr. F. Gordon Dexter. In July, 1862, it flowered in England, for the first time in Europe, with Messrs. Veitch, from bulbs sent from Japan by their collector, John Gould Veitch.

The Japanese eat the bulbs of Lilium auratum and several other species, but for its beauty they do not esteem it or any other true Lily-they never did. But in due time, after intercourse was established between Japan and western nations, largely through the vigorous action in 1853-54, of Commodore Perry 
of the U. S. Navy, the Japanese discovered that Lily bulbs could be sold for much money, so they began ransacking their country in quest of these bulbs. In those early days we are told the Yama-juri, or Mountain Lily (L. auratum), grew abundantly in the volcanic ash and detritus which form the slopes of sacred and sublime Mount Fuji. To-day it still grows there but in decreasing numbers; yet it is even now the most common wild Lily in Japan. In the volcanic deposits throughout the province of Idzu it is abundant and near by on the small island of Oshima, whose central part is an ever active volcano, grows in quantity the broad-leaved auratum (L. auratum, var. platyphyllum).

For western markets the dealers demand Lily bulbs of certain sizes. After a few years the Japanese discovered that the supply of wild bulbs meeting the necessary requirements was virtually exhausted, but they quickly found that in rich, moist farm land, in one or at most two years, they could grow the small bulbs culled from the mountain slopes and moorlands into large saleable bulbs and, incidentally, that the larger the bulb the higher its market value. Then began in Japan the growing of Lily bulbs for the western markets and here commenced the troubles of would-be cultivators in the Occident of Lilium auratum. In 
books on Lilies one reads "Lilium auratum grows in porous, open soil largely composed of volcanic detritus overlaid by a deep carpet of woodland soil." The first part of this statement is true but the "deep carpet of woodland soil" is pure fiction.

In Japan there is much poor and hungry soil but none more so than the slopes of august Fuji and the volcanic deposits of the Idzu province. Around Matsushima, a beauty spot in northern Japan, I saw this Lily wild in quantity growing among coarse grass and shrubs on low hills and hillocks of pure, gray sandstone. In western Japan, in the province of Uzen, I also met with it growing wild on gravelly banks and hillsides among small shrubs and coarse grasses. It is the open, porous soil, and not the rich humus, that this Lily luxuriates in. Leafsoil it loves in common with all Lilies, but it wants no unaërated acid peat and it loathes raw nitrogenous manures. True, bulbs transferred from their natural haunts to fields and cultivated like potatoes increase rapidly in size but the constitution of the plant is undermined and it becomes a prey to fungoid diseases.

There is a minimum size to every kind of Lily bulb below which it cannot produce strong, flowering stems. This size varies according to the particular species, but in every case a firm, solid bulb of moderate 
size will be found more healthy and will give results more satisfactory than a large, loose, and flabby bulb. Purchasers who make mere size their standard of value often defeat the object they have most closely in view. I examined some bulbs of the wild $L$. auratum and found them only about a couple of inches in diameter though they bore heads of from three to six flowers and, also, were absolutely free of any sign of disease. Later, I asked one of the largest and perhaps the best-informed Japanese grower of Lilies why he did not dig and sell these wild bulbs since they were so healthy and vigorous. With a smile he answered: "My dear sir, I tried it once and found that neither in Europe nor America could a purchaser be found for bulbs so small!"

Of the genus Lilium, to which all true Lilies belong, about eighty species are known. All are confined to the waste places of the Northern Hemisphere and more than half of them are indigenous in China and Japan. The genus ranges through the temperate and subtropic regions from eastern North America to California and through eastern Asia, the Himalayas, and Siberia to the extreme limits of western Europe. It is absent from the plains of the middle west of North America and from central Asia, and there are other considerable gaps in the field of distribution. Two 
species are found within and confined to the tropics, viz., L. philippinense in the Philippine Islands, and $L$. neilgherrense on the Neilgherry Hills in southern India. In this wide domain species of Lilium are found under diverse conditions and a moment's reflection should convince us of the futility of attempting to cultivate in any one garden all the species obtainable. Botanists, chiefly on the shape of the flowers, divide Lilies into five groups, viz.-

I. Flowers strongly recurved and suggestive of a Turk's cap, a familiar example being the Tiger Lily (L. tigrinum).

II. Flowers large and funnel-shaped as in the common Easter Lily ( $L$. longiflorum).

III. Flowers like a saucer or shallow basin as in the Golden-rayed Lily of Japan (L. auratum).

IV. Flowers erect as in the Umbellate Lily ( $L$. umbellatum).

V. Leaves broad and heart-shaped as in the Giant Lily (L. giganteum).

For horticultural purposes a much more simple classification may be invoked. For gardens in cool temperate regions Lilies may be divided into two broad groups:

(A.) Hardy Lilies of which L. tigrinum, L. regale, and L. Henryi may serve as examples. 
(B.) Not Hardy, of which may be cited L. longiflorum, L. sulphureum, and L. nepalense.

Again, they may be divided into Swamp Lilies which would include nearly all the American species, and Dry-land Lilies which would include most of the species of China and Japan. With almost equal propriety these groups might be styled humus-loving and loam-loving respectively.

Also, we might divide Lilies into shade-loving kinds, as for example, L. giganteum, and sun-loving such as $L$. regale. But, not to waste time it may be laid down as a law that in the average garden situated in the temperate parts of North America, only such species of Lily as are perfectly hardy withstand sun, and, call for moderately dry land, have any chance of becoming successful denizens. For such gardens swamp Lilies, woodland Lilies, and alpine Lilies, with a few exceptions, may be ruled out entirely.

Most species of Lilies detest lime; to many it is a deadly poison; to none, so far as we know, is lime essential; but some, like $L$. candidum, L. martagon, and L. testaceum, are apparently indifferent to its presence in the soil.

All Lilies demand good drainage. When one thinks of swamp Lilies this statement may sound un- 
scientific. But dig up a few of these Lilies and note carefully the exact conditions under which they grow. It will be found that the bulb rests on a stone or a piece of rock, or in a tuft of firm sod, or nestles in gritty sand. The roots are in wet mud or may even hang free in the water; but the bulb is so placed that water cannot stagnate immediately under and around it, and in winter it is fairly dry.

A few swamp Lilies like the native L. superbum and the Panther Lily (L. pardalinum) of California may be grown without difficulty among Rhododendrons; but for those requiring more moisture, if their culture be attempted, it is a good plan to invert a flower-pot at the requisite depth, place the bulb on the upturned base and surround it with silver- or gritty river-sand.

Sun-loving Lilies, although the upper part of their stems are fully exposed and their blossoms flaunt in the sun, really require a certain amount of protection from the direct rays in the early stages of their growth. Lilies are not desert plants, and the most sun-loving among them are never found in areas where no other plant grows. True, some of them are denizens of semi-arid regions but they are ever associated with grasses or twiggy shrubs, among and through which their young shoots are upthrust and which break the sun's direct rays. Some species like the Regal Lily 
(L. regale, better known under the erroneous name of L. myriophyllum), can withstand much desiccation but these in a natural state have their foil of herbs and scrub.

Journey in thought with me, for a moment or two, westward until "west" becomes "east" although we still chase the setting sun. Across this continent, across that broad ocean misnamed "Pacific," to Shanghai, the gate of Far Cathay; onward and westward up the mighty Yangtsze River for eighteen hundred miles, then northward, up its tributary the Min, some two hundred and fifty miles to the confines of mysterious Thibet; to that little-known hinterland which separates China proper from the hierarchy of Lhassa; to a wild and mountainous country peopled mainly by strange tribesfolk of unknown origin; to a land where Lamaism, Buddhism, and Phallism strive for mastery of men's souls; to a region where mighty empires meet. There in narrow, semi-arid valleys down which thunder torrents, and encompassed by mountains composed of mudshales and granites whose peaks are clothed with snow eternal, the Regal Lily has its home. In summer the heat is terrific, in winter the cold is intense, and at all seasons these valleys are subject to sudden and violent windstorms against which neither man nor beast can make headway. There, in June, by the 
wayside, in rock-crevices by the torrent's edge, and high up on the mountainside and precipice this Lily in full bloom greets the weary wayfarer. Not in twos and threes; but in hundreds, in thousands, aye, in tens of thousands. Its slender stems, each two to four feet tall, flexible and tense as steel, overtopping the coarse grass and scrub and crowned with one to several large, funnel-shaped flowers more or less winecolored without, pure white and lustrous on the face, clear canary-yellow within the tube and each stamen tipped with a golden anther. The air in the cool of the morning and in the evening is laden with soft, delicious perfume exhaled from each bloom. For a brief season this lonely, semi-desert region is transformed by this Lily into a veritable fairyland.

Since we have, figuratively, traveled so far to see one Lily in its home surroundings, let us in the same manner journey a hundred miles or so farther and to the southwest, and there, in valleys clothed with coarse grasses and low shrubs and under conditions but little less severe than the preceding and in equal abundance, we find Mrs. Charles S. Sargent's Lily ( $L$. Sargentiae) reigning supreme. Westward some few miles and on the margin of shrubberies at eight thousand feet above sea level and on the very edge of the Thibetan grasslands grows Mrs. Bayard Thayer's Lily 
(L. Thayerae). There are other Lilies which we have not time to consider but on our homeward journey let us pause for a moment in the geographical heart of China, in the region of the famous Yangtsze Gorges, and visit the haunt of the Orangeflowered Speciosum (L. Henryi). Inland a few miles from the riverine city of Ichang, on formations of conglomerate and hard carboniferous limestones, at the edge of woods and among tall shrubs we find here a few and there many of Henry's charming Lily.

From these distant regions came the bulbs of these Lilies, and I count it a privilege to have been the fortunate discoverer of two, the introducer of three, and the medium through which the fourth (L. Henryi) first became common in cultivation. I could tell of others equally beautiful were any good purpose to be served and I mention these four not for personal reasons but to direct attention to the conditions under which they grow wild and to emphasize that, though sun-loving and capable of withstanding much desiccation both from the action of sun and frost, they grow naturally among protective herbs and shrubs. These herbs and shrubs afford protection in two ways: in spring they screen from the sun's direct rays the young flower-stem of the Lily after it emerges from mother earth; in the autumn the fallen leaves of the shrubs 
and the dying culms of the herbs form a protective mulch which as it decays becomes a nourishing food.

This brief sketch of the conditions under which certain Lilies grow wild enables us to deduce certain facts of cultural importance. In the first place, Lilies should be planted among Ferns, or dwarf shrubs such, for example, as Lavender, wild Roses, Deutzias, Indigoferas, Lespedezas, Comptonia, Vacciniums, Ericas, Calluna, native Azaleas, Rhododendrons and, where climate admits, shrubby Veronicas and Olearias.

Planting Lilies among shrubs is no new idea; twenty-five years or more ago it came into vogue. Some one achieved great success through planting Lilies among Rhododendrons and the cry went forth that this was the solution of the Lily grower's troubles-plant Lilies among Rhododendrons! It is quite true that a number of species like $L$. pardalinum, L. superbum, L. speciosum, L. Hansonii (and I have also seen $L$. auratum) do well under such conditions. Also it is true that Rhododendrons require peat and here is the rub. All Lilies love leafsoil but a great many detest peat. I have seen L. Henryi grow ten feet tall in loam and leafsoil and continue to thrive for many years. I have seen this Lily disappear completely in two seasons when planted in pure peat. Plant Lilies among shrubs, but let the class of 
shrubs depend upon whether the particular species of Lily loves loam or humus. For my own part I would keep away from peat except for swamp Lilies and use fibrous loam, sand, and leafsoil, the latter in increasing proportion as to species that grow naturally in fairly open country, thickets, or woods.

Another and very obvious deduction is the importance of mulching. In every garden much ground is bare of vegetation and fully exposed to the sun and elements. In spring, as the frost disappears, an inspection will show that this ground is fissured and furrowed in many directions and any kind of bulb which had been planted in such bare soil is often more or less exposed. This may be avoided and much benefit bestowed on all bulbs by covering them in autumn with a mulch of rotted leaves or exhausted manure.

Strictly speaking, a bulb is a bud just as much so as the winter-bud of a Hickory or Horsechestnut, but with this difference: its scales are fleshy storehouses of starch and other food reserves instead of merely dry and chaffy protective scales, and roots are emitted from the base. These basal roots anchor the bulb and supply it with water and certain food salts. If we examine Lilies like L. Henryi, L. auratum, and $L$. regale we find that the underground part of the 
flowering stem bears masses of roots. These help to feed the growing stem and prevent undue exhaustion of the bulb. After flowering this root system assists in the rehabilitation of the bulb. Roots emitted from the stem above the ground quickly perish. An appreciation of these facts shows the necessity of deep planting. The bulbs of all stem-rooting Lilies (and the majority are such) should be planted twice their own depth down. That is to say, a bulb three inches high should have six inches of soil covering it and so on in proportion. The importance of deep planting is not sufficiently understood, but go and dig up a few Lily bulbs from their native haunts and it will be found they are usually deeper down than twice their height.

The majority of Lilies are at rest, or nearly so, during the winter months but all kinds benefit from planting as early in the fall as is possible.

The Madonna Lily ( $L$. candidum) is an exception in several ways. In the first place, it resents moving. When this has to be done it should be undertaken not later than six weeks after flowering as the resting period of this Lily is unusually short. Again, it should be noted that this Lily has a mass of broad basal leaves independent of the flowering stem and it is these leaves with the assistance of the roots that 
build up the bulb. This Lily should have the top of its bulb only just covered with soil. It prefers rather stiff loam in a situation fully exposed to the sun but it will grow in dry and hungry limestone soils. Bulbs grown in the south of England are the best though the majority of dealers still insist that French-grown bulbs are superior.

From this cursory consideration of the conditions in which Lilies grow wild in various parts of the world a few facts of cardinal importance to the Lily lover may be deduced. In the first place, since Lilies inhabit the waste places of the Northern Hemisphere it is obvious that they are unaccustomed to rich food. For this reason even stable manure should not be used in their culture and artificial fertilizers are absolutely inimical. All Lilies grow naturally in places where each autumn they receive a mulch of fallen leaves. Leafsoil and not manure is the requisite essential. Nearly all grow in well-drained situations and good drainage is absolutely necessary to ensure success. Lilies of the swamp, woodland, and alpine meadow are with rare exceptions difficult to cultivate. Those which grow among shrubs and herbs more or less exposed to the sun are less exacting and in this class is found the majority of the sorts amenable to cultivation in ordinary gardens. 
It is not possible to lay down any hard and fast rules, but good, sound bulbs and a common-sense attention to a few elementary details are the essentials. Several kinds of Lilies present no more difficulties under cultivation than do Narcissi and Tulips; nevertheless in most gardens to maintain Lilies in good health new soil or removal to a new site is necessary every few years.

The following species will be found to thrive and give satisfaction in any and every garden in temperate climes with the sine qua non that sound bulbs only be planted: L. tigrinum, L. umbellatum, L. Hansonii, L. pardalinum, L. superbum, L. candidum, L. croceum, L. Henryi, L. regale, L. Sargentiae $L$. auratum, L. speciosum, L. testaceum, and L. Thayerae. 


\section{CHAPTER III}

\section{MIDSEASON FLOWERING TREES AND SHRUBS}

LITTLE REALIZED OPPORTUNITIES FOR FLOWERS IN THE SUMMER TIME-WHAT OUR PARKS AND GARDENS MIGHT EASILY DISPLAY

HE geographical area of the United States of America is so immense and the climate is 1. so diversified that there is ample room in which to accommodate out of doors all the kinds of woody plants known from the Northern and Southern hemispheres outside of the tropics. In California the trees and shrubs of the temperate regions of the Southern Hemisphere thrive amazingly, and it is probable that in this state alone a greater variety of woody plants can be successfully grown in the open ground than in any similar area in the world. I mentioned the Southern Hemisphere, but it should be added that the trees and shrubs of China, Japan, the Himalayas, southern Europe, the Caucasus, and the Mediterranean region of northern Africa are equally at home in California.

In contrast it may be stated that in the Arnold 36 

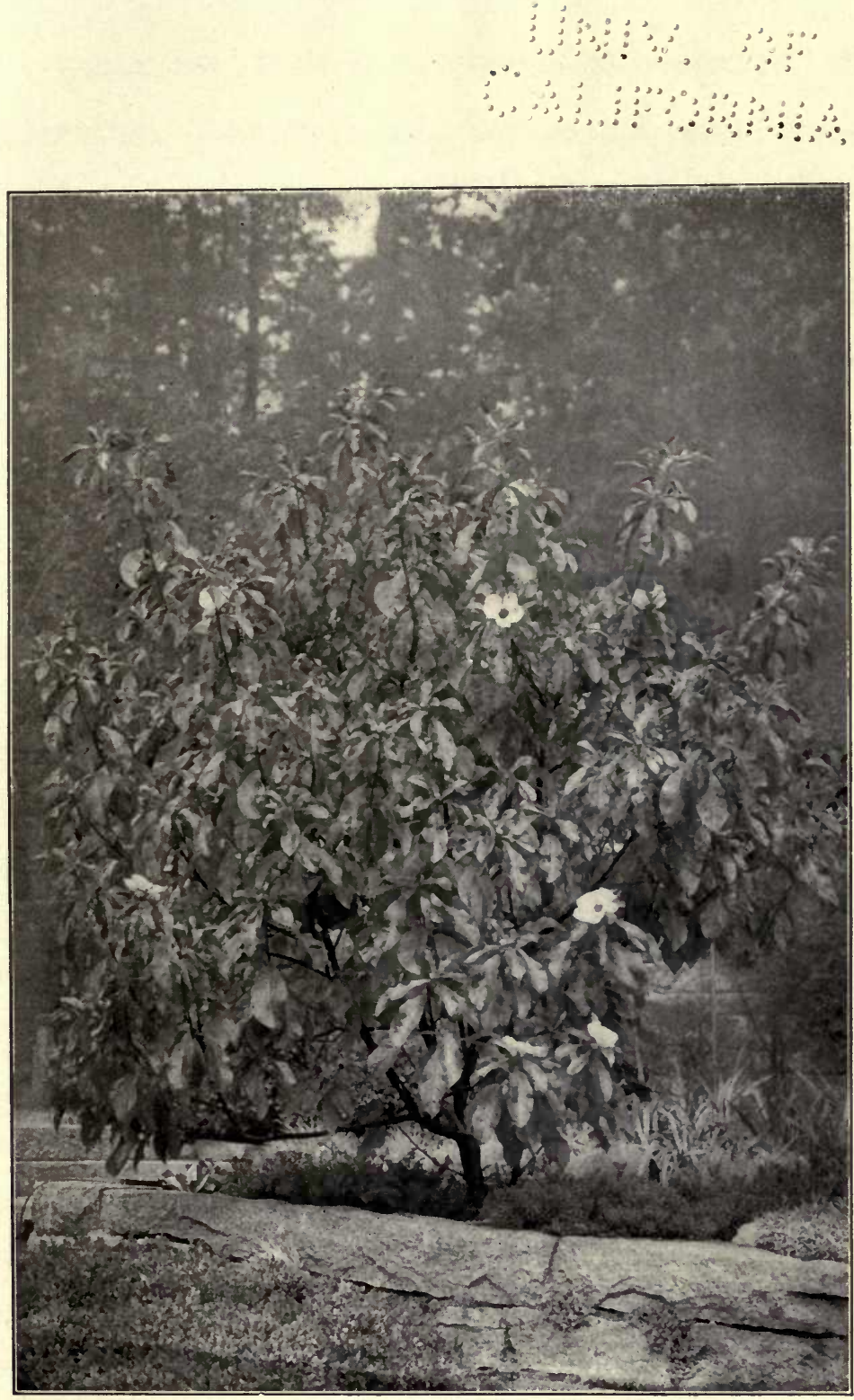

Among the later flowering trees the native American Gordonia altamaha is one of great interest. The white flowers appear in August and September 
$40 \quad y+y^{2}$

tat 
MIDSEASON FLOWERING TREES AND SHRUBS 37 Arboretum, Boston, Mass., it has not been found possible to cultivate successfully any tree or shrub native of the Southern Hemisphere. Many of the trees native of Europe thrive indifferently here and virtually no exotic broad-leaved evergreen will withstand the vagaries of this austere New England climate.

The United States of America is a land of extremes but the horticultural possibilities are well-nigh illimitable. The day will dawn when throughout the length and breadth of this land there will be country homes and their attendant gardens. Much pioneer work has been done and progress is being made but the consummation of these efforts is with the future.

Though paradoxical, it is none the less true, that the very size of this country and the diversity of its climate simplify in general, and at the same time complicate in detail, the efforts of those who treat of horticultural matters. Statements of a general nature may be absolutely true yet utterly misleading unless duly qualified. For example, I might assert that several species of Eucalyptus and Acacia are perfectly hardy and quick-growing trees in the United States of America and recommend their being extensively planted in parks and gardens. To the people of California such a statement would be 
accepted as demonstrably true. To the people of Massachusetts it would seem ridiculous nonsense!

Therefore, in writing on horticultural matters, and especially on those which are strongly influenced by climate, it is necessary that one specify to what particular part of a country his statements are intended to apply. It is unfortunate that one's efforts must be circumscribed, but the controlling factors are beyond human restraint. In the case of these pages it must be remembered that they have definite reference mainly to gardens in the temperate parts of eastern North America. The scope is broad, but details are necessary; and it is climate that controls these details since the plants I write of are recommended for the embellishment of parks and outdoor gardens.

Eastern North America is singularly rich in native species of ornamental flowering trees and shrubs, and in spring and early summer the waysides and woodlands are everywhere gay with conspicuous flowers. About midsummer this wealth of blossom ceases in so far as woody plants are concerned, and tallgrowing herbs in meadow and swamp, in thicket and forest-glade, proudly flaunt their multicolored flowers. Even in cold New England, Nature so economizes that there are very few weeks in the whole year when absolutely no flowers are to be found out of doors. 
MIDSEASON FLOWERING TREES AND SHRUBS 39 Taking a lesson from Dame Nature every well-ordered garden should be so stocked that a succession of flowers be maintained.

At summer resorts the gardeners' efforts are largely directed toward the growing of plants which blossom from the beginning of July to mid-September. Herbaceous perennials, tender herbaceous exotics, and certain bulbous plants, together with a few shrubs such as Rose of Sharon (Hibiscus syriacus), the Hardy Hydrangea (Hydrangea paniculata), and the Tender Hydrangea or Hortensia ( $H$. opuloides, commonly known as $H$. hortensis), and $H$. opuloides, var. otaksa are utilized to produce the necessary display of flowers. Without being critical it may be said that there is a sameness in the floral displays of most summer gardens which is varied only by design and quantity. There is no particular reason for being dissatisfied, but, among woody plants which flower during this season a much greater variety could advantageously be grown and much beauty and charm added thereby. The number though relatively small is much greater than many suppose. Some of these plants are natives of eastern North America, a good many are indigenous in China and Japan, whilst others hail from various parts of Europe and temperate Asia. Some of these I now propose to discuss in brief detail. 
During the early part of July the Lindens (Tilia), the largest genus of summer-flowering trees, put forth their fragrant, honey-laden, pendent blossoms. The native Sweet Bay (Magnolia glauca) with cupshaped white flowers is also in blossom, and in wet seasons a second crop of flowers appears on Magnolia cordata. This medium-sized native tree has beautiful cup-shaped yellow flowers and its history is more than ordinarily interesting. It was originally discovered by the elder Michaux in the neighborhood of Augusta, Georgia, some time between 1787 and 1796, and by him (or his son) introduced into France. The trees now in cultivation are derived from these original introductions of Michaux. All efforts to rediscover this Magnolia failed until about two years ago when Mr. Louis A. Berckmans accidentally "happened" upon it in a dry wood some eighteen miles south of Augusta. Michaux describes it as a tree from forty to fifty feet tall, but the recent discoveries are bushes from four to six feet tall.

From the middle to the end of July the Sourwood or Sorrel Tree (Oxydendrum arboreum), another American tree, is in flower. A native of the Appalachian Mountains where it grows thirty feet and more tall, this member of the Heath family is quite hardy in Massachusetts where it commences to blossom when 
only a few feet high. The white, urn-shaped flowers are produced in great profusion in terminal, spreading and slightly drooping compound clusters and last for a long time. The bright green leaves have a pleasant acidulous taste and turn in the autumn bright scarlet. The Sourwood is apparently free of disease and is not subject to insect pests; it is perfectly hardy and well deserves a place in every garden.

Of the several hardy exotic trees which flower in July and August at least three merit wider recogninition, viz. - the Varnish Tree (Köelreuteria paniculata), the Pagoda Tree (Sophora japonica), and the Acanthopanax (Kalopanax ricinifolium).

The Köelreuteria is native of northern China and was introduced into Petrograd from the neighborhood of Peking some time between 1740 and 1756 . It was introduced in 1763, into England by Lord Coventry, presumably from Petrograd. Though known in cultivation for more than a century and a half it is far from being as generally planted as its beauty warrants. It is a small tree from twenty to thirty feet tall with spreading branches, large, shining green, pinnately, divided leaves, and erect much-branched panicles, a foot and more high, of numerous bright yellow flowers which are followed by bladder-like top-shaped fruits. In the color of its flowers Köelreuteria is unique among 
midseason flowering trees. It is much cultivated in Peking gardens and will withstand heat and drought as well as cold. In the semi-arid valleys of western China another and closely allied species (K. apiculata) is common and is now in cultivation in western gardens.

The Sophora is allied to the Locust tree but, fortunately unlike the latter, it is not subject to attacks of boring insects. Its specific name notwithstanding, Sophora japonica is indigenous in China and is only known as a cultivated tree in Japan, having been introduced by Buddhist priests perhaps a thousand years ago. In China this tree is widely dispersed and in the extreme west is very common in rocky and sandy semi-arid valleys. It is a very hardy tree, from sixty to eighty feet tall, and has a dense widespreading oval or flattened crown, and toward the end of July and in August every branchlet terminates in an erect branching cluster of creamy-white flowers which are followed by slender, curiously constricted saponaceous pod-like fruits.

This Sophora flowered first under cultivation near Paris in 1779, having been raised from seeds sent from Peking by Father d'Incarville, a Jesuit priest, about 1747. On sandy soil in the Royal Gardens, Kew, where it was received from Paris through J. Gordon in 
1753 , this tree thrives remarkably and some magnificent specimens may be seen there. Here in Boston, Mass., there are growing several fine old trees. In the park in which stands the Temple of Heaven at Peking there is a grand old avenue of this tree. The individuals are large, with deeply furrowed dark gray bark and in winter they are singularly Oak-like in general appearance. In temple grounds in Japan fine specimen trees are occasionally met with. In China the flowers of the Sophora are used in preparing a yellow dye for silk.

The Kalopanax is a member of the Ivy family and is one of the noblest trees of the cool temperate regions. It occurs wild, scattered through the moist forests from the extreme south to the limits of northern Japan. It is most abundant in Hokkaido, in Korea, and also in central and western China where it is a valuable timber tree. This tree grows to a large size and in Japan specimens eighty feet tall with a trunk from fifteen to twenty feet in girth are not rare. In old trees the bark is gray and deeply furrowed, the branches thick and spreading to form a flattened or rounded crown. In young trees the branches are erect-spreading and both they and the trunk are armed with scattered, short, stout spines. The dark green leaves on long stalks are very like those 
of the Castor-oil plant (Ricinus) and to this resemblance the tree owes its specific name. In late July and in August each branchlet bears a broad, flat compound cluster of white flowers which are rapidly followed by shin ng black Elderberry-like fruits. The large and handsome palmate leaves give this tree a tropical appearance yet it is perfectly hardy and quick-growing. In the Arnold Arboretum may be seen two trees each thirty-five feet tall, raised from seeds collected in Japan by Professor Sargent in 1892. These trees flower and fruit each year and have done so for several years past. This Kalopanax thrives in ordinary garden soil but prefers a moist situation. As far as is known it is not attacked by any insect or disease. As a lawn tree or as a specimen tree by side of water it is unsurpassed and also it ought to be used for street planting. In Hokkaido this tree is known as the "Sen," and the wood, which is white with a fine grain, is exported to China for railway ties and to Europe for making shop-fittings, panels, and office furniture. Another Japanese tree, Stewartia pseudocamellia, a member of the Camellia family, also blossoms about the end of July and is much too rare in gardens. In the moist forests of the Nikko region this tree is abundant and is easily recognized by its perfectly smooth gray-brown bark; the branches are 
ascending and form a narrow head. The flowers are saucer-shaped, white with a mass of yellow stamens; they are very freely produced and the tree is strikingly ornamental. Its eastern North American relative. $(S$. pentagyna) which is native of the southern Appalachian region, is a tall shrub with larger, more cup-shaped flowers which appear about mid-July. Both these Stewartias are hardy as far north as Boston. A near and equally hardy relative of these is Gordonia altamaha, one of the most beautiful and most interesting of late-flowering American plants. It is a shrub from fifteen to twenty feet high with obovate-oblong leaves and pure white cup or saucer-shaped flowers with conspicuous yellow stamens which are produced from August to late September. It was discovered in the region of the Altamaha River, in Georgia, by John Bartram, in 1765, and introduced by his son William into England in 1774, but all plants now in cultivation are from his second collection in 1778. No one has seen this plant wild since 1790 .

Other late-flowering trees worthy of a place in gardens are Rhus javanica (better known as $R$. Osbeckii or $R$. semialata), Clerodendron trichotomum, and C. trichotomum, var. Fargesii, all three native of China and Japan. Unfortunately the two Clerodendrons are not hardy as far north as Boston, Mass. 
Of shrubs there is quite a variety which blossom during the midseason. By the middle of July the last of the Buckeyes (Aesculus parviflora) is in flower. This native of the southeastern states is a broad, round-topped, much-branched shrub from six to ten feet high, and every branchlet terminates in long, narrow, erect spikes of small white flowers in which the stamens are long exserted. This shrub requires good soil and a moist situation, and is well suited for planting in large masses or as a single specimen.

The Pepperbush (Clethra), of which three species are hardy in the Arnold Arboretum, is perhaps the most beautiful group of native shrubs which flower from mid-July. The most common is Clethra alnifolia, a denizen of swamp borders and moist places in the neighborhood of the coast from Maine to Florida. As usually seen it is a bush from four to six feet tall, with white, fragrant flowers borne in erect, terminal compound clusters. Unfortunately the leaves are often disfigured by attacks of red spider. A second species (C. tomentosa) is native of Florida and flowers two or three weeks later than the preceding from which it differs chiefly in the covering of white hairs on the lower surface of the leaves. The third (C. acuminata) is an inhabitant of the forests of the southern Ap- 
palachian Mountains and is a less desirable garden plant. A fourth species (C. canescens), hardy in the vicinity of Boston, hails from Japan and exceeds in beauty any of the American kinds, but unfortunately it does not readily make itself at home with us. The inflorescence is larger than in the American species and the plant grows to a greater size. As I write I have in mind a fine specimen fully fourteen feet high, which is growing on a windswept corner in a garden at Winchester, Mass. Every year each branchlet of this bush terminates in large clusters of fragrant white flowers. In Japan this Pepperbush is widely distributed and in moist forests is often a tree forty feet tall with a smooth gray-brown trunk five feet and more in girth.

At midseason the Spiræas are all past but their place is well taken by the closely allied genus Sorbaria which is distinguished by its pinnate leaves and terminal compound panicles of flowers. Five species are hardy in the Arnold Arboretum and thrive in ordinary garden soil. The best results are obtained by planting them in rich loam in a moist place, and by the side of a pond or stream their grace and beauty are seen to best advantage. They are excellent subjects for the wild garden and to develop their full beauty they must have plenty of room. One of the 
finest of these Sorbarias is S. arborea, a very common shrub in central and western China whence I introduced it into the Arnold Arboretum and elsewhere. On the Chino-Thibetan borderland this plant is very abundant and grows from fifteen to twenty feet high and as much through, and bears in profusion much-branched arching panicles often two feet long of pure-white flowers. From the extreme northwestern Himalayas came S. Aitchisonii, with smooth shoots and pale green leaves and even larger masses of flowers than the preceding which it resembles in size and habit. In Hokkaido and Saghalien the well-known S. sorbifolia is a shrub from three to five feet tall with erect shoots which terminate in rigidly upright wide-branched panicles eighteen inches high. I retain a vivid recollection of the picture this shrub presented during August in Saghalien. There, on the margins of grassy swamps and swampy woodlands and by the side of streams and ponds, this plant luxuriates in great abundance; its pyramids of white flowers with their prominent stamens, reared on rigid stems three to five feet tall and subtended by numerous large deep green leaves, presented a never-to-be-forgotten spectacle in that lonely, silent land.

The other two species ( $S$. assurgens from western China and S. stellipila from northern Japan) are also 
well worth growing. A sixth species (S. Lindleyana) from the Himalayas is not hardy with us.

Three species of Adam's Needle (Yucca flaccida, native of the southern Appalachians, Y. filamentosa from Stone Mountain, Georgia, and Y. glauca, native of the eastern slopes of the Rocky Mountains) are hardy in the Arnold Arboretum. With their spearlike leaves these plants are interesting at all seasons and when in flower there are few if any subjects more beautiful. The tall, branching inflorescence and nodding white flowers, in the daytime more or less top-shaped, expand on moonlight nights when they attract the moths which effect the fertilization of the flowers.

Of shrubs with yellow flowers there are several, all native of southern Europe, the Caucasus, and Asia Minor, which blossom in July. Most interesting among these are Cytisus nigricans, C. capitatus, and Genista tinctoria, var. elata, all three good garden plants unfortunately too rarely seen in American gardens. The Bladder Sennas (Colutea arborescens and C. cilicica) flower in July, and C. orientalis, which flowers earlier is covered with large, thin-walled inflated pods which are tinged with pink and are very ornamental.

The yellow shrubby Cinquefoil (Potentilla fruti- 
$\cos a$ ), its variety parvifolia and the white-flowered variety Veitchii, blossom in early and late summer and do well in sunny situations. A St. John's Wort (Hypericum patulum, var. Henryi), a newcomer from western China which grows from two to three feet tall and bears large deep yellow flowers, is also worthy of note. With blue or bluish flowers two shrubby species of Clematis ( $C$. heracleaefolia from northern China, C. stans from Japan) bloom during this midseason. Of each there are several varieties and the flowers are more or less tubular in shape. These plants grow about three feet tall and behave much as do herbaceous perennials. Another beautiful little plant with blue flowers unfortunately not hardy around Boston is Caryopteris incana (better known as C. Mastacanthus), a native of Japan and China.

The largest group of midseason shrubs has flowers of pink, red, and purple. Belonging to the Pea family the most beautiful are Indigofera and Lespedeza. Of the first named $I$. Kirilowii, with bright rose-pink flowers, hails from Korea and northern China, and I. decora, with white flowers, from Japan and northern China. Both are low, sub-shrubby plants with twiggy shoots and bright green pinnate leaves and large, lovely flowers on long, erect racemes. They commence to blossom in late June and continue to do so 
for a couple of months. Another species, I. Gerardiana from the Himalayas, has rose-colored flowers but it is a less valuable plant for northern gardens. A fourth and new introduction from central China is I. amblyantha. This is an erect, little-branching shrub from five to six feet tall with erect racemes of pink or rose-red colored flowers. It is a pleasing plant and remarkable inasmuch as the racemes continue to elongate and produce blossoms from late June until the frosts appear.

Of Lespedeza the hardiest are L. bicolor, L. formosa, and $L$. crytobotrya, all three twiggy, floriferous shrubs.

A very charming subject much too infrequently met with in gardens is Callicarpa japonica. This plant has opposite leaves and from the axil of each and every one arise short-stalked flattened clusters of pinkish flowers. These are quickly followed by masses of small, round, rose-purple fruits which last until the frosts come and which, as the generic name indicates, are very beautiful.

A comparatively new and highly desirable plant is Elsholtzia Stauntonii, introduced in 1905, into the Arnold Arboretum by Mr. J. G. Jack from near the Great Wall of China north of Peking. This is almost a herbaceous plant and may be treated as such. It 
has terminal and lateral, more or less erect racemes of rose-purple flowers with long, exserted stamens and is most attractive.

As a group with lilac, rose, and vinous-purple flowers the most valuable recent addition to midseason shrubs is unquestionably Buddleia Davidii (more generally known as $B$. variabilis) and its varieties, and these are fast winning well-deserved popularity in this country under the name of Summer Lilac. They are inhabitants of central and western China where they are essentially fluviatile plants though here and there they ascend moist herb or shrub-clad slopes. They are scarcely hardy as far north as Boston, Mass., but cuttings of half-ripe wood inserted under glass in autumn root readily and these if planted out early in June will make large bushes and flower profusely in August and September. A rich, loamy soil, full sunshine, and an abundant water supply are the essentials. Grown in this manner I have measured the tail-like inflorescence over thirty inches long. In the Garden Magazine, April, 1916, appeared an illustrated article on these plants so there is no need even for the introducer to enter into further details concerning them. But as an expression of opinion perhaps I may be allowed to say that my own favorite is the var. magnifica which is distinguished by its 
relatively large, intense violet-purple flowers with the edge of the petals crinkled and slightly recurved. And, further, I do vigorously protest against the absurd name of "Butterfly Bush" which some dealers would fain foist upon us as a popular name for these shrubs.

As finality is impossible I must omit details on some of the more generally known midseason flowering shrubs such as Veronica augustifolia, its varieties and hybrids, Ceanothus hybridus and others, Abelia grandiflora, Amorpha canescens and certain other plants, yet I must have a word or two on those favorite low-growing shrubs, the Ling and Hardy Heaths. People other than those of Scotch descent have a warm affection for these charming little shrubs and there is no valid reason why this fondness should not be indulged. Ling and Heaths are sunloving plants and their successful culture demands that they be planted in open situations fully exposed to the sun. A moist, sandy soil in which peat is liberally admixed are the other requisites, and the plants thrive better in shallow than in deep soils. The hardiest of the Heaths are Erica carnea and its variety alba which commence to blossom in early spring as the snow and frosts disappear. The Cornish Heath, E. vagans and its varieties alba, grandiflora, and rubra, 
and the Ling (Calluna vulgaris) of which there are more than a dozen varieties, are almost equally hardy and commence to flower in July and continue in blossom until the late autumn. Other Heaths like E. Mackaii, E. stricta, E. Tetralix, E. cinerea (Downy Heath) and Doböecia polifolia (Irish Heath) are not hardy as far north as Boston, Mass., but they will probably thrive south of New York City. 
$\frac{1}{4}$

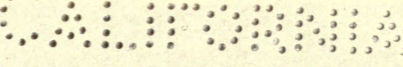




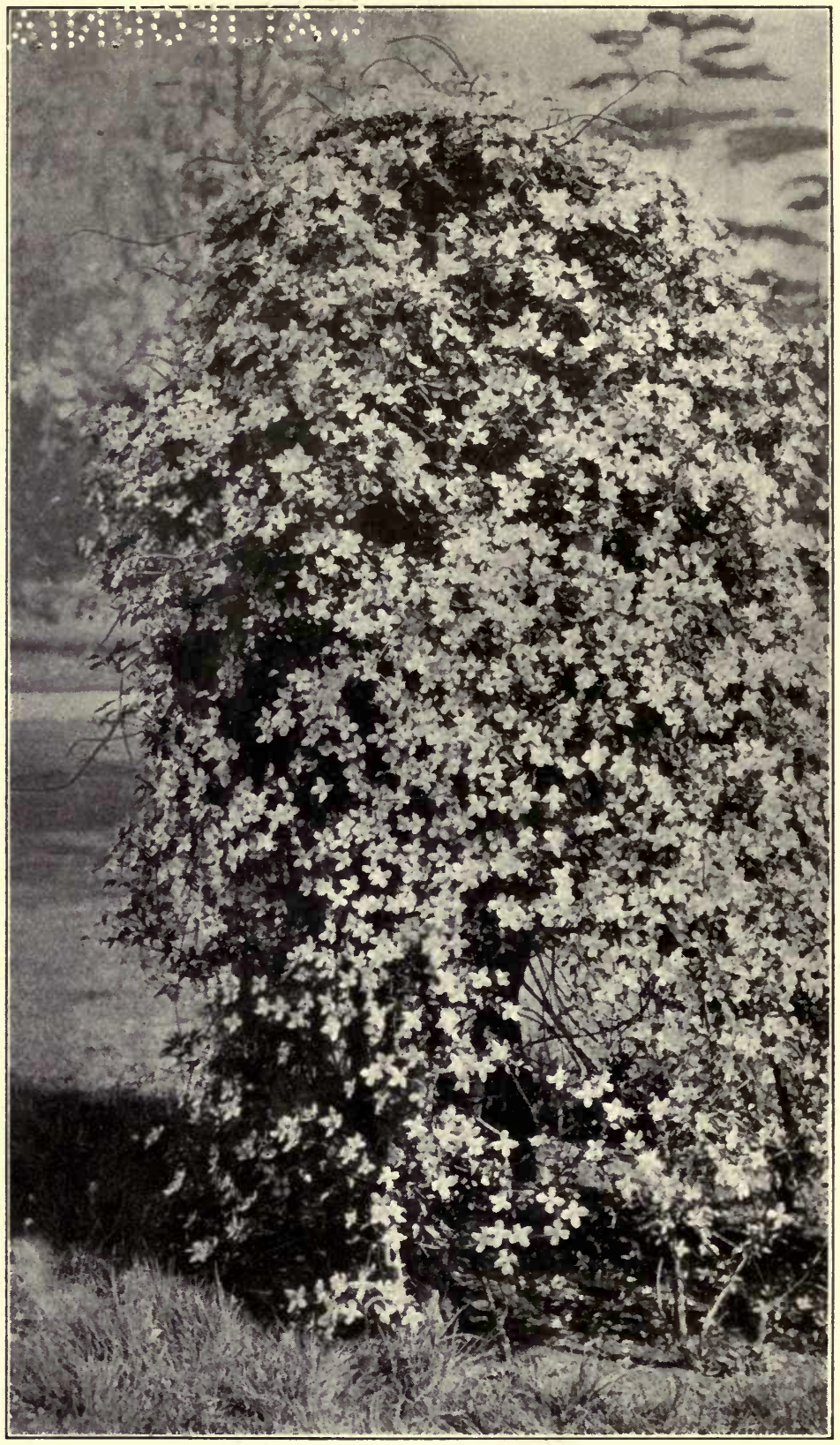

Clematis montana $\cdot v a r$. rubens, about three inches across, is an attractive vine with rose colored flowers. It is not quite hardy in New England 


\section{CHAPTER IV}

\section{THE BEST OF THE HARDY CLIMBING SHRUBS}

PERMANENT VINES FOR TRELLIS AND WALL THAT WILL GIVE A SUCCESSION OF FLOWER TO LATE FALL

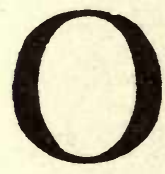

NE of the fundamental properties of the living substance of plantsand animals (protoplasm) is irritability or sensitiveness - the power of responding to external stimuli. The class of plants under consideration here owes its origin to this peculiar property, and the most casual among us may derive both pleasure and instruction from observing this irritability in operation. Twining stems and other organs specially adapted for the purpose of assisting plants to climb are very sensitive to contact. Further, if the necessary contact or external stimulus be denied the growth of many climbing plants is retarded. For example, when the young shoots of Pole Beans commence to elongate and cast round as it were (nutate) for some support every gardener and farmer knows that poles must be affixed or the crop of beans will be a failure. In the forests 
and thickets where climbing plants grow wild their associate plants are seized upon and forced to assist these climbers in rearing themselves against gravity toward the sunlight.

A majority of our hardy woody climbers, for example Wistaria, Actinidia, Celastrus, climb by means of twining stems. In a number the stems coil in a definite direction and refuse absolutely to be cajoled into twining in any other direction. For example: the shoots of a common European Woodbine (Lonicera Caprifolium) twine from right to left (clockwise), those of the Dutchman's Pipe (Aristolochia durior) twine from left to right (counter-clockwise). The why of this is outside our immediate discussion but that it is fact may be proven by all who will take the trouble to examine these plants.

Another large group climbs by means of tendrils which are specially modified organs. In the Grapevine (Vitis) an abortive inflorescence developed from the side of the shoot opposite the leaf is the specially adapted climbing organ. The closely allied Boston Ivy (Parthenocissus tricuspidata) has the free ends of the tendril flattened into discs which firmly adhere to walls and rocks. In Smilax the stipules are modified to form tendrils. In Clematis the stalk of the leaf and leaflets serves the purpose. In another group to 
which belongs Ivy (Hedera Helix), Climbing Hydrangea (Hydrangea petiolaris) and Evonymus radicans, short roots are freely emitted everywhere on the stem on the side away from the light and these adhere tenaciously to the object affording support. In the Trumpet-flower (Campsis) the shoots twine somewhat and also emit roots but only from definite localized points. Other plants like certain Roses climb or cling by means of hooked prickles.

These facts are not merely interesting in themselves but are of direct practical importance to all who wish to enjoy in their gardens climbing plants since they indicate clearly the nature of the support needed by each group.

It is the fashion nowadays to erect in the immediate vicinity of the house a heavy, massive structure of masonry or wood and style it euphemistically a pergola. As to its merits as an architectural feature I have no criticism to offer. In lands of perennial sunshine like southern California, Arizona, and other dry southern states, such arbors clothed with climbing plants dowered with ample foliage afford welcome relief and serve as cool and delightful retreats from the hot sun's rays. But in northern lands such structures, if intended primarily for the accommodation of climbing plants, would certainly look more attractive 
and be equally serviceable if constructed on a less massive scale. To my mind the dominant features in any and every garden should be the living plants themselves, and structures erected for their accommodation should be subordinate to the requirements of the plants. As an illustration, some friend invites us to view his or her Rambler Roses. Now it is the Roses we admire and it is intended that we should admire them, and not the structure on which they cling, no matter how costly or architecturally beautiful this structure may happen to be. Simplicity combined with mechanical stability should be the sine qua non of all structures intended for the accommodation of climbing plants in the garden or the immediate precincts of the house.

Neat posts made of reinforced concrete and firmly inserted fifteen to eighteen feet apart in the ground with stout copper or galvanized wire run through make a lasting trellis which if ten feet high will serve for all the perfectly hardy stem and tendril-climbing plants. Climbers so planted display their beauty to the best advantage and this arrangement will form an excellent screen to the garden or it may be so affixed as to form an avenue or arbor. Note, however, that it is said those "perfectly hardy" for be it remembered that on a trellis the plants are fully exposed to the 
elements and especially to the strong winds and draughts which are far more trying than low temperatures. Under the lee of a stone fence is the ideal site for planting climbers of all sorts and a far greater number will thrive under such conditions than on a trellis. Hook-climbers and many stem-climbers do well and look most effective if planted among or on top of large boulders where they can develop into a dense tangle. On such rocks if planted at the base root-climbers and those which have discs at the ends of their tendrils do well. Root-climbers also thrive on the north and west sides of buildings and likewise on trees. If climbers be planted with the intention of their ascending and wandering over trees it should be borne in mind that sooner or later it means the death of the tree by strangulation and suffocation.

Climbing plants are found nearly all over the world. They are especially abundant in the tropics where they form a most striking feature in the forests. They are also plentiful in moist forests of the temperate regions of both hemispheres but they are absent from alpine and arctic regions. Broadly speaking, it may be said that they occur everywhere where trees and large shrubs grow and the more moist the climate the more exuberant their growth. Always they grow in association with other woody plants which afford 
them not only means of support but protection from cold, chilling draughts. In eastern North America there are many native climbers of great beauty and ornamental value and the variety available for the embellishment of gardens situated in cold northern districts is much greater than many suppose. A selection of these I now propose to pass in brief review.

Unquestionably the most beautiful of all climbers hardy in cool temperate regions is Wistaria, everywhere so deservedly popular and widely cultivated. Now the name Wistaria was given in 1818 , by the American botanist, Nuttall, to an American plant (W. frutescens), which had been in cultivation in England since 1724, as Glycine frutescens, in honor of an American physician Dr. Caspar Wistar, Professor of Anatomy in the University of Pennsylvania. In 1818, John Reeves, an officer of the English East India Company, sent from Canton, China, to England, a climber which received the name Glycine sinensis. In 1825 , De Candolle, a Frenchman, correctly referred this plant to Nuttall's genus Wistaria. To-day, and for many decades past, Wistaria and Wistaria sinensis have been synonymous in the popular mind. Indeed, comparatively few people know that here in eastern North America there are native species of Wistaria, so 
completely has their oriental relative surpassed them in popular appreciation.

The Chinese Wistaria is native of the eastern part of China and is not completely hardy as far north as Boston, Mass. It requires some protection and this is usually afforded by planting it against houses. Even then in severe winters the flower buds get killed.

In scenes of Japanese gardens and temple grounds and in Japanese paintings and embroideries most people are familiar with a Wistaria having very long racemes of flowers. This plant is known generally as Wistaria multijuga but is really only a garden form of the common wild Wistaria of Japan (W. floribunda) and correctly should be called $W$. floribunda, var. macrobotrys. The type is abundant on the margins of moist woods and thickets and especially by the side of streams, ponds, and ditches virtually all over Japan and has racemes of pale purple flowers one and one-half feet long. In Japanese gardens forms with white and pinkish flowers with racemes two and two and one-half feet long are cultivated, and also a purple-flowered form with racemes which I myself have measured sixty-four and one-half inches long! These plants are always grown by the side of ponds and streams and the stems trained to form an arbor, and it is unlimited water 
supply during the time of flowering that accounts for the phenomenally long racemes. Did we in New England attempt to cultivate this plant in the Japanese manner I fear King Frost would play sad havoc and the results would be less satisfactory than those we at present achieve. But farther south the plan would doubtless succeed, and even in the north some simple means of providing the plants with an abundant water supply as the flower buds expand could be found.

The Japanese Wistaria was introduced into Europe about 1870-2, but seeds were received in this country by Samuel Parsons of Flushing, Long Island, in March, 1862, from Dr. George R. Hall. It is hardier than its more widely known Chinese relative and therefore deserves to be more generally cultivated in the north. The flowers are slightly smaller and open rather later but are fragrant and equally beautiful. The white, purple, and pinkish forms are equally hardy and may be grown in the manner as the Chinese species usually is or on a trellis. There is also a form with ugly double purple flowers. This was first cultivated in this country in the garden of Francis Parkman, the historian, at Jamaica Plain, Mass., in 1862, having been received from Japan through Mr. F. Gordon Dexter. 
The Japanese Wistaria is erratic in the matter of flowering and if raised from seeds decades may pass before any flowers appear. Grafts from flowering plants should be used in propagating and by this means plants only three to four feet tall will blossom.

One of the most vigorous, hardy, and popular of all stem-climbers is Actinidia arguta, a native of Japan, which has glossy green leaves with red stalks and small, saucer-shaped white flowers with numerous stamens and black anthers. There are two forms of this and all other species of Actinidia, one with purely male flowers and another with perfect flowers. The latter bears fruits which are edible and which may be made into a preserve. Two other hardy Japanese species of Actinidia ( $A$. kolomikta and $A$. polygama) are in cultivation and in these a varying number of the foliage leaves are white passing to pinkish and increase the attractiveness of these plants. Unfortunately cats have a strong partiality for $A$. polygama, clawing and tearing it into shreds, and good examples are rarely seen. Those desiring to grow this climber must protect it from cats by wire netting. The handsomest of all the Actinidias and one of the most beautiful of all climbers is $A$. chinensis and it is much to be regretted that this valuable new plant is not hardy so far north as Boston, Mass. It is a vig- 
orous grower with large leaves varying in shape from nearly round to ovate and pointed, and large white, changing to buff-yellow, deliciously fragrant flowers. The shoots and leaves when young are covered with crimson hairs which add much to the beauty of the plant. The fruits are rounded to oval, from one and onehalf to two inches long, russet-colored and more or less hairy. The skin of the fruit is very thin and the flesh is green, sweet, and pleasant to the palate, and is excellent for dessert or for making a preserve. In the south and west there is a future for this Actinidia not only as an ornamental but also as a fruit-bearing climber. Although discovered in China by Robert Fortune in 1846, it was not introduced until 1900, when I first sent seeds to England.

A comparatively new, hardy, and very beautiful plant is Tripterygium Regelii, with brown, spotted stems, bright green leaves, and large clusters of small white flowers which are followed by curious, winged fruits. It is native of Japan and Korea and so also are Schisandra chinensis, Akebia lobata, and A. quinata. These are hardy stem-climbers with good foliage, rather inconspicuous flowers, and ornamental fruits. Very free-flowering climbers in June are Periploca graeca from southeastern Europe and $P$. sepium from northern China which have glossy green 
leaves and curious purplish flowers with recurved petals with horn-like outgrowths at the base. The Chinese plant is the hardier. The Supple-Jack (Berchemia scandens) from the southeastern states and its Japanese relative $B$. racemosa are hardy and have neat, deep green prominently veined leaves, small greenish flowers, and bunches of red changing to shining black fruits.

The native Waxwork (Celastrus scandens) and its relatives $C$. articulata and $C$. flagellaris from northeast Asia and Japan are good trellis plants but they are seen to best advantage as a tangle on and over large rocks. The first two have the male and female flowers on different plants but in C. flagellaris, which has little hooks at the base of the leaf-stalk that assist it to climb, the sexes are on the same individual. In the autumn when laden with yellow fruit which opens and exposes the seeds with their brilliant orange-scarlet coverings, there are few plants of equal beauty. If branches be cut just as the fruits commence to open and placed in vases without water the ornamental value is retained throughout the winter. The best of the three species is $C$. articulata.

For planting against low walls and on rocks the Matrimony-vines (Lycium chinense and L. halimifolium) are very useful and in late summer and 
autumn when laden with their conspicuous scarlet fruits they are very attractive.

A very beautiful twining plant but one not always easily established is Polygonum baldschuanicum from central Asia. It grows eight to twelve feet tall and produces masses of white flowers which change to pink with age. Its near relative $P$. multiflorum, from China and Japan, is a much more vigorous grower with larger clusters of flowers but it is not nearly so hardy and cannot be grown out of doors as far north as Boston, Mass.

Among the American species of Honeysuckle there are several good hardy climbers but the best is Lonicera Heckrotti, a hybrid of unknown origin. From the middle of June until the early frosts appear this plant is in blossom. The flowers which are borne in clusters, are deep rose color without and pale yellow within and though fragrant only in the evening they are very beautiful. Very vigorous growers are $L$. flava and L. glaucescens, with yellow flowers; L. prolifera (better known as $L$. Sullivantii) with yellowish flowers; and $L$. sempervirens with scarlet flowers; L. hirsuta has hairy leaves and flowers with a yellow tube and orange-red lip; and the hybrid L. Brownii and its form fuchsioides have wine-colored flowers. The European Honeysuckles or Woodbines, (L. Per- 
iclymenum of which there are several varieties one of which var. belgica, known as the Dutch Honeysuckle, is continuous blooming) and L. Caprifolium are or ought to be well-known favorites. Hall's semi-evergreen Japan Honeysuckle (L. japonica, var. Halliana) needs no comment and even more beautiful is the Chinese variety (L. japonica, var. chinensis) with red-colored young shoots and leaves. The Chinese name for this plant, Chin-yin-hwa, i. e., Gold and Silver flower, is singularly appropriate. Many of these Honeysuckles are very subject to the attacks of a black aphis and they can only be kept in good condition by careful spraying with an antidote early in the season as the leaves unfold.

The Trumpet-flower (Campsis radicans, better known as Tecoma radicans), a native of Missouri and Texas to Virginia, is a common and much appreciated climber. The variety praecox and the hybrid $C$. hybrida are also valuable plants, but these are in size and beauty of flowers surpassed by their Chinese relative $C$. chinensis, though unfortunately it is much less hardy. In the Chinese plant the flowers are orange-scarlet and the shade is more pleasing than that of the American kinds. All are vigorous growers with shining green divided leaves and they climb by means of tufts of roots emitted from the stem oppo- 
site the base of the leaf stalks. Closely allied to this is the Cross-vine (Anisostichus capreolatus, better known as Bignonia capreolata) so abundant in the southeastern states, and which has large trumpetshaped flowers orange-yellow within the tube, dark scarlet without. This plant which climbs by means of tendrils which have discs at the ends, is not hardy around Boston though with care it can be kept alive.

A root-climber that should be in every garden is the Climbing Hydrangea ( $H$. petiolaris). It is perfectly hardy and does well on walls with a north or west exposure, on buildings and on trees, and bears at the ends of short lateral branches flat clusters eight to ten inches across of white flowers. The leaves are of good size, deep green in color and the plant is not subject to insect attacks or disease. This climber is abundant in the moist forests of Japan and was introduced into the Arnold Arboretum in 1876. I have seen in the forests of northern Japan and in Hokkaido trees from seventy to eighty feet tall covered with masses of flowers of this Hydrangea and a most fascinating picture they presented.

A smaller growing Japanese climber and even more beautiful than the preceding but unfortunately less easy to establish, is Schizophragma hydrangeoides. It is very like the Climbing Hydrangea in foliage and 
habit but the inflorescence on the outside has pure white ovate bracts instead of four-partite sterile flowers. This plant does well at Newport, R. I., but is difficult to procure. The name appears in most catalogues of nursery stock but the plant supplied under this name is almost invariably the Climbing Hydrangea.

Clematis has more variously colored flowers than any other genus of hardy climbers. There are species with white, blue, pink, scarlet, claret-red, and yellow flowers and their flowering season is from the early summer until autumn. They are excellent subjects for trellises, low walls and arbors but it should be remembered that these plants are fond of lime. The large star-shaped flowers of the Japanese C. patens, and $C$. florida which also grows in China, and the Chinese C. lanuginosa; the European C. Viticella, their various colored garden forms; and the Jackmani hybrids which are mixtures of all three, captivate the attention wherever seen and all garden lovers desire to possess them. The white flowered $C$. montana from eastern Asia is an old favorite. A variety of this ( $C$. montana, var. rubens) with rosecolored flowers from two and one fourth to three inches across and dark foliage, which I had the pleasure of introducing to cultivation in 1900 , is acclaimed by 
garden-lovers to be one of the most beautiful of all the Clematis. Around Boston it has not proved completely hardy; but at Newport, R. I., some good examples may be seen. The white-flowered $C$. Fargesii and the summer-blooming C. montana, var. Wilsonii with large fascicles of flowers are also desirable plants. In June blossoms C. tangutica, which has pale green leaves and lovely clear yellow top-shaped flowers, and is a native of northwestern China; also the scarletflowered $C$. coccinea from Texas. Another hardy species from northern China is C. glauca. This and its variety akebioides have bronzy yellow obconical flowers which are produced in August. In early September the Japanese C. apiifolia is a billowy mass of small white flowers and its well-known fellow countryman, C. paniculata, is quite indispensable. This list could easily be extended but it includes the best and most easily grown kinds which supply a succession of flowers over the full period of summer.

Of climbing plants with handsome leaves no class exceeds in vigor and beauty the Grapevines (Vitis). Many beautiful species are native of this country, but the noblest of all is $V$. Coignetiae from northern Japan. This Vine has broad heart-shaped leaves of enormous size and much substance, dark green and netted above with a felt of brown hairs on the under- 
side and in autumn they change to scarlet and crimson. It is the most vigorous of Hardy Vines and in the moist forests of northern Japan climbs to the tops of trees sixty feet and more tall, and in the thickets, glades, and on the margins of woods and swamps, makes an impenetrable jungle. The fruit is jet black, globose and edible and the plant is one to which breeders of new fruits might well turn their attention. This climber is very common in the colder parts of Japan and I shall long remember its exuberant growth and vivid autumn coloring as I saw it around Lake Towada in early October, 1914.

Another equally hardy species but less vigorous and with smaller leaves is $V$. amurensis from eastern Siberia. From China, western gardens have recently received a number of new and ornamental species of Vitis and in England they have become very popular. Unfortunately they have not proved quite hardy in this country as far north as Boston, Mass. but there is ample room to the south on this Atlantic seaboard not to mention the Pacific slope. Perhaps the most beautiful of these newcomers is $V$. Davidii (more usually called $V$. armata) and its variety cyanocarpa (better known as Veitchii), which have prickly shoots and large glossy metallic green, heartshaped pointed leaves pale on the underside and 
changing in the autumn to scarlet and crimson. Other good sorts are V. reticulata, $V$. betulifolia, $V$. pentagona, $V$. Piasezkii with variously incised and lobed leaves, V. flexuosa, var. parvifolia (commonly known as var. Wilsonii) with small lustrous metallic green leaves and $V$. Romanetii with bristly shoots.

Temperate North America is remarkably rich in species of Vitis and in the Arnold Arboretum no fewer than fourteen are perfectly hardy on the trellises. All are good and it is not easy to make a selection. Among the handsomest are $V$. cinerea, $V$. bicolor, and V. Doaniana. The first-named grows wild on the river banks of the Mississippi Valley from Illinois to Kansas and Texas. It is a most vigorous plant with leaves dark green above, ashy gray below and, like the young shoots, clothed when they unfold with a felt of gray hairs. The second species is native of the northern and middle states and is equally vigorous and has large deeply lobed leaves which are dark green above and bluish green below. The third is a comparatively new plant, native of the Texas Panhandle but is quite hardy and fast growing with large rather pale bluish-green leaves of very firm texture. Other beautiful Vines are the Summer Grape ( $V$. aestivalis) with the leaves rusty-brown on 
the under side; the Frost Grape ( $V$. cordifolia) with thin light green leaves; the Sugar Grape (V.rupestris) with small, shining metallic green leaves and reddish shoots; and V. labrusca, the common Fox Grape of New England. For covering trellises and walls the native Grapevines are invaluable and their merit deserve the widest recognition.

Three most widely grown climbers are the native Virginia Creepers (Parthenocissus vitacea, $P$. quinquefolia) and the Boston Ivy ( $P$. tricuspidata, better known as Ampelopsis Veitchii) a native of China and Japan, and all three are remarkable for the brilliant autumn colors of their leaves. The hardiest of the trio is $P$. quinquefolia, which in nurseries is usually sold under the name of Ampelopsis Englemanii. This is hardy as far north as Ottawa, Canada, and clings to walls and buildings by means of discs at the ends of the tendrils. There are several varieties, the best, known as San Paulii, is common in Illinois and Missouri. In Europe $P$. quinquefolia is little known and there $P$. vitacea passes for it. This, however, is a very different plant and will not cling to walls but with its shining green leaves and rich autumn tints it is a splendid plant for trellis-work. Two other beautiful but less hardy species from China are $P$. Henryana, which has a white stripe down the centre 
of each lobe of the leaf, and $P$. Thomsonii with reddish leaves claret-purple on the underside.

In foliage the most delicate and attractive and in fruit among the most beautiful of all climbers is Ampelopsis aconitifolia and its variety palmiloba. The leaves are finely dissected and the fruit which is freely produced changes as it ripens from yellow to blue and pale purple. The closely allied $A$. humulifolia, $A$. micans, $A$. heterophylla and $A$. brevipedunculata, all from China, have clear turquoise blue fruits. A remarkable species is $A$. megalophylla, a new-comer also from China, with much divided leaves a yard across.

Among the Birthworts (Aristolochia) are several hardy climbers well worth growing for the sake of their foliage; mention may be made of $A$. tomentosa and $A$. durior (better known as $A$. sipho) whose curious flowers gave origin to its vernacular name of Dutchman's Pipe, natives of eastern North America, and their relatives $A$. moupinensis from western China and A. Kaempferi from Japan. The flowers of these plants though not conspicuous are very interesting and their fertilization is effected by flies.

The Moonseeds too have fine foliage, and their curiously ridged and curved seeds are enclosed in fleshy blue-black fruits. Three species are hardy, 
viz: the Canadian Moonseed (Menispermum canadense), eastern Siberian ( $M$. dauricum), and the Chinese (Sinomenium acutum). A closely allied twiner is Cocculus trilobus (better known as C. Thunbergii) native of China and Japan which is remarkable for the variability in shape of its leaves.

The native Greenbriers (Smilax rotundifolia and $S$. hispida), with their Japanese relative $S$. Sieboldii and two or three other species, are interesting as being the only hardy woody climbers in one great division of the vegetable world to which belong the Palms and Grasses and which is designated by botanists Monocotyledons.

Species of evergreen climbers are few in number in the north temperate regions and none occurs in the cold northern parts of this continent. In the Arnold Arboretum the only really hardy and satisfactory evergreen climber is the Japanese Evonymus (E. radicans) and its variety vegetus. These are rootclimbers and do well on walls and trees and like other plants of their class form a bushy growth when old enough to produce flowers. The axillary shortstalked clusters of greenish-white flowers appear in late June and are followed by white fruits which open and display in marked contrast the seeds with their orange-scarlet coverings. The type has narrowly 
ovate pointed to lance-shaped leaves; the variety vegetus obovate to broadly oval leaves rounded at the apex, dark green and (in the winter in particular) glossy. This variety, which is a better garden plant than the type, was raised in the Arnold Arboretum from seeds received from Sapporo, Hokkaido, in 1876. In both of these plants a variegated condition often appears though it is more frequent in the type. In the juvenile stage these plants have marbled leaves and look very different from the adult condition. A prostrate plant sold in nurseries as E. kewensis or $E$. minimus with small broadly oval, marbled leaves is nothing but a juvenile form of $E$. radicans, var. vegetus. It originated from seeds collected in Japan by Professor Sargent in 1892.

A new and hardy Honeysuckle (L. Henryi) from China is a welcome addition to the small list of evergreen climbers. The clustered flowers are tubular, reddish within and yellow stained red without but are not very conspicuous and these are followed by dull black fruits. The leaves are dark green of good size and substance and keep their color through the winter. This plant makes a fine tangle over rocks or on the bare ground, but is not very satisfactory on a trellis around Boston.

In milder climates south of Boston, Mass., the 
common Ivy (Hedera Helix), of which there are many distinct and striking forms, should be cultivated. This plant ranges through Europe, northern Africa and northern Asia to Japan and is extremely polymorphic. The varieties amurensis, chrysocarpa, colchica, crenata, deltoidea, rhombea and canariensis (Irish Ivy) are among the best. There are also many variegated forms and those who like such plants may indulge their fancy. The new Clematis Armandi from central China with white flowers, and its form Farquhariana with pink flowers, should be especially useful in the south and on the Pacific Slope. The three-foliolate leaves are dark polished green and the flowers each two to three inches across are freely produced in large axillary clusters. For gardens situated where a genial climate prevails I count this Clematis among the most desirable and beautiful of plants I have been privileged to introduce into cultivation. 


\section{CHAPTER V \\ ORNAMENTAL FRUITED TREES AND SHRUBS}

ABUNDANCE OF AVAILABLE MATERIAL TO GIVE BRILLIANCY AND CHARACTER TO AMERICAN GARDENS DURING FALL AND WINTER

T OVERS of woody plants who live in eastern North America enjoy certain advantages over their British compeers and for these the muchabused climate is responsible. In New England and the north generally, we are denied the wealth of hardy evergreen plants which thrive in Old England and the variety of plants which will grow out of doors is less, but there are compensations. The plants that do thrive here grow more rapidly, flower more freely, and fruit very much more profusely than they do on the opposite side of the Atlantic Ocean. Nothing strikes a horticulturist from Great Britain more forcibly than the wealth of fruit which here develops on the shrubs and trees. Such visitors find that many old and familiar plants possess a world of beauty heretofore quite unknown to them, and certain it is that all the perfectly hardy woody plants put 


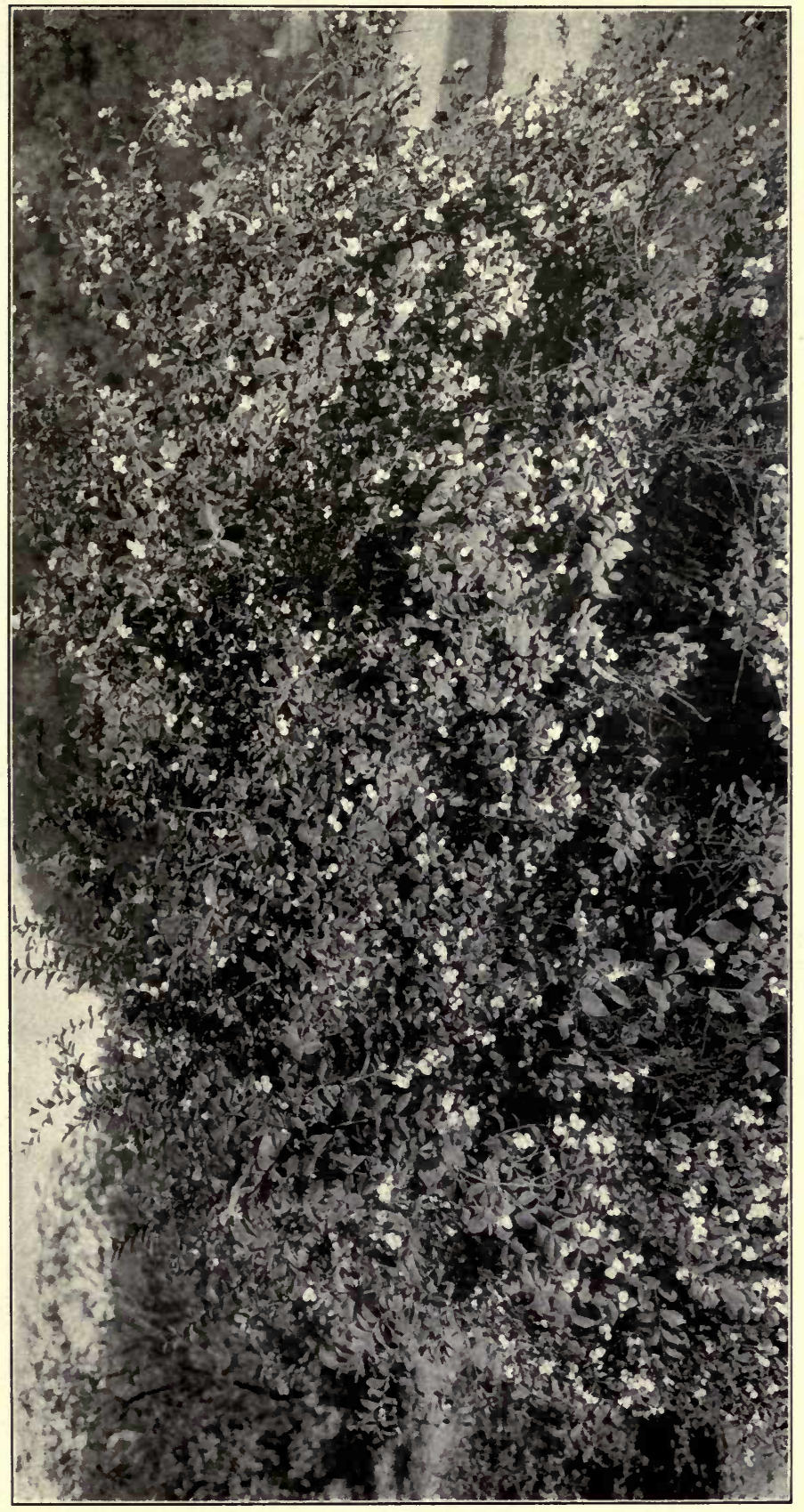

흘

․ㅗㄹ

$\stackrel{\sim}{ \pm}$

4



옹

ช

등

혹

을

$\lambda$ 플

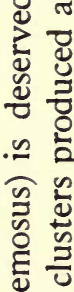

(ี)

ช

ㄴ.

E

क

(2)

닌

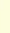

ज

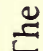



forth their maximum ornamental qualities in this climate.

The full value of trees and shrubs for their ornamental fruits is not properly appreciated at the present time, otherwise a more extensive variety would be planted. A great number, as for example: the Honeysuckles, Dogwoods, Viburnums, Crabapples, and Wild Roses, also have strikingly beautiful flowers. The utilitarian spirit has been keen on developing and cultivating trees and shrubs bearing edible fruits, but aesthetic taste has rather neglected those of purely ornamental value. We shall get round to a proper appreciation of these later, and in due time in planting our shrubberies and borders we shall inquire not merely what kind and color of flowers a woody plant has but also the color and character of its fruit. Indeed, to make sure of these facts the tendency to visit notable collections and see for ourselves will grow stronger, and less and less will garden lovers be content to accept opinion second hand. The increased love of and for gardens now happily evident in this country will not always be satisfied with the very limited variety of good shrubs and trees commonly purchasable but will insist that those who make a business of supplying these plants keep in stock an all-round selection of the most valuable and really hardy orna- 
mental woody plants. As interest and knowledge increase the intrinsic value of Arboreta will become apparent and the educational import of such institutions will receive its proper recognition from a discerning public who will duly appreciate the advantages derived from the experimental testing of the hardiness, adaptability, and ornamental qualities of all the available material which has been culled from the uttermost parts of the world.

Every flowering plant produces fruit, and in character and form the variety is infinite. In this chapter we are only concerned with such hardy woody plants as bear succulent fruits all of which on ripening assume more or less brilliant colors. In the development of the flower and in the perfecting of the fruit Nature's objective is definite. It may be set forth as an axiom that in the diversity of form among flowers Nature's endeavor is mainly to insure their fertilization through the agency of the insect world: in the perfecting of the succulent fruit it is toward making it attractive to birds so as to insure through their agency the dispersal of the seeds. Dame Nature is prodigal, but although she apparently cares nothing for the individual she lavishes endeavor on securing the perpetuation of the species and the safety of the race.

This coöperation invoked by Nature opens up 
another interesting field. Nowadays people are beginning to appreciate the feathered world and public opinion is aroused to the necessity of preserving our birds. Societies have been formed with this object in view and laws have been promulgated for the furtherance of this purpose. Far and wide the habit is spreading of fixing up boxes of various designs to serve as nesting places for our feathered friends. All this is very laudable, but something more is necessary since birds require food, and especially during the winter months, as well as houses in which to rear their young. The natural food of a great number of our useful birds is in part or wholly the fruits of plants. Therefore, whosoever plants trees and shrubs bearing succulent fruits also provides the birds with a supply of food.

The United States Department of Agriculture is giving attention to this important matter and in March, 1914, one of the investigators visited the Arnold Arboretum for the purpose of studying the plants growing there which might furnish birds with winter food. "His examination revealed the fact that fleshy fruits of the sort eaten by birds were still hanging on the branches, and in good condition, of one hundred and ten species of woody plants, and that the fruit on fifteen other species, although dry, was still 
available as bird food. Of these one hundred and twenty-five species only forty-nine are natives of the United States and only thirty of New England." I quote the Bulletin of the Arnold Arboretum, and it will be remembered that the winter of 1913-14 was one of the severest recorded for this part of the world. Among succulent fruits, black and white and all the colors of the spectrum are represented but, in contrast with flowers, the colors are usually pure. Varicolored fruits are almost non-existent although among crabapples, plums, cherries, and their kin the color may vary on different sides of the same fruit. Yellowcolored flowers are very abundant, but yellow fruits are decidedly rare among hardy northern plants. In flowers botanists do not regard mere color as of distinctive importance but with fruits in general it is of considerable and often significant value.

In eastern North America, even for the cold climate of New England, there is available a vast array of woody plants which bear succulent, bright, colored fruits. A great many are native and others have come from Europe and Asia and more especially from China and Japan. Of shrubs the most important family hardy in the northeastern part of North America is probably the Honeysuckle family which includes not only Climbing and Bush Honeysuckles but 
that beautiful group known as Viburnum and also the Snowberries (Symphoricarpos) and Elderberries (Sambucus). This family is closely followed and perhaps equalled by that of the Rose which includes trees as well as shrubs. The more important members are the Hawthorns (Crataegus), the Crabapples (Malus), the Rowan (Sorbus), Plums and Cherries (Prunus), Blackberries and Raspberries (Rubus), Cotoneaster, and the Rose itself. In these two families black and white and all the cardinal colors except green occur. Next in order may be placed the Dogwood family and the single genus Cornus has black, white, red, and blue fruits on its different species. The Gooseberry and Currants (Ribes) have not only black, white, red, yellow, purple, and wine-colored but also green or greenish fruits. The only other hardy shrub I can think of with greenish-colored fruit is the native Leatherwood (Dirca palustris). Perhaps the most popular family of berried plants is that of the Holly (Ilex) which has red, black, and yellow fruits. Then there are the Barberries with red, black, and purple fruits; the Spindle-tree (Evonymus) and Waxwork (Celastrus), which belong to the same family, have white, pink, red, and orange-colored fruits which open and display the seeds with their orange or scarlet covering. The Ivy and Rhamnus families mostly 
have black fruits; the Mulberry and its relative the Hackberry (Celtis) black, white, red, and orangecolored fruit. The Spicebush (Benzoin aestivale) has scarlet fruit and the Sassafras, black fruit seated in a scarlet-colored cup. The Elaeagnus and its allies have red or orange-red fruits; the Blueberries (Vaccinium) black, blue-black, and red fruits. The native Persimmon (Diospyros virginiana) has orangecolored and the Tupelos (Nyssa) mostly blue-black fruits. The Asiatic Corktree (Phellodendron) has black and many of the Sumachs (Rhus) red fruits. Lastly, mention may be made of Symplocos paniculata, a native of the Far East, which has clear turquoise-blue fruit.

The fourth chapter deals with climbing plants, so they are excluded from what follows and attention is concentrated on trees and shrubs. Perhaps it will conduce to clearness if we divide our subject into groups denoted by color, but it is well to remember that such grouping must often be a little arbitrary.

\section{RED FRUITS}

Under this general heading may be classed a large and attractive group whose conspicuous and handsome fruits are striking at any season but are especially so in winter. Among native trees and shrubs un- 
doubtedly the most beautiful are the Hawthorns (Crataegus) whose decorative value is not fully realized. The number of species is very great and some are low shrubs and others large trees; the fruit varies greatly in size and in the length of time it remains on the branches. In a group so large selection is onerous but the six which follow, though equalled by others, are not surpassed by any. The so-called Washington Thorn (C. cordata) is a slender tree, from twenty to thirty-five feet tall, with a small and shapely crown and clusters of small scarlet shining fruits which ripen in October and remain on the tree without much change in color until the spring. In $C$. nitida, which is a large tree with spreading slightly pendulous branches, the scarlet fruits are of medium size in drooping clusters, ripening in October and remaining on the trees until winter is far advanced. A remarkably handsome species is C. Arnoldiana with large bright crimson fruits ripening about the middle of August and falling in September. This is a small tree with ascending and spreading branches and slender very zigzag branchlets which form a broad irregular crown. Crataegus succulenta is a shrub or small tree with a broad irregular head and drooping clusters of moderately large, globose, bright scarlet fruits which ripen about mid-September and remain on the 
branches until the middle of November. Another shrub or slender tree is $C$. pruinosa with horizontally spreading branches and large, sub-globose purple-red fruits in clusters ripening late in October and remaining on the branches until about the end of November. The Cockspur Thorn (C.crus-galli) is a moderate-sized tree with rigid, spreading branches and drooping clusters of fairly large sub-globose dull red fruits which ripen late in October and remain on the branches until spring. Mention must also be made of $C$. punctata which has drooping clusters of large sub-globose fruits, dull red or bright yellow in color and which ripen and fall in October. This well-known Hawthorn is a moderately flat-topped tree with stout, straight spreading branches and is widely distributed from the St. Lawrence Valley to North Carolina and to Illinois.

The best known of the Old World Hawthorns are C. Oxyacantha and C. monogyna of which there are very many varieties and in which dull red-colored fruits predominate. A species from northern China and Mandshuria (C. pinnatifida) with red fruits is one of the best of all Hawthorns. The wild form is a medium-sized shrub with relatively small fruits, but this species has long been cultivated as a fruit tree in orchards in northern China and by cultivation it has developed into a tree with large and edible fruit. 
ORNAMENTAL FRUITED TREES AND SHRUBS 87

Closely allied to Crataegus is Sorbus Aucuparia, the Mountain Ash or Rowan-tree, and when laden with its broad flat clusters of small bright scarlet fruits has no peer among ornamental fruited trees. There are several varieties including a form with pendulous branches and another with yellow fruits. Scattered over the north temperate regions are several species closely allied to the foregoing, and in this country grows $S$. americana and its large fruited variety decora, possibly the most beautiful of all.

The Flowering Dogwood (Cornus florida), appreciated as one of the most beautiful of native trees of small size, is also strikingly handsome in the fall when laden with its scarlet teat-like fruits in close heads. The Old World Cornus mas bears red cherry-like fruits, hence its vernacular name, Cornelian Cherry. There is a variety of this (xanthocarpa) with yellow fruit.

The English Holly (Ilex Aquifolium) with its bright red berries and shining green leaves and so celebrated in poetry and folk-lore is not hardy around Boston, Mass., but farther south it may be grown and there is no more beautiful evergreen tree. Among its very numerous varieties is one (fructu-luteo) with yellow fruits. The native Holly (I. opaca) with dull green leaves is a hardier but inferior tree from an ornamental viewpoint. The native Black Alder or Winter- 
berry ( $I$. verticillata), its ally $I$. laevigata, and the Japanese $I$. Sieboldii are hardy shrubs with deciduous leaves and strikingly beautiful with their clusters of scarlet fruits. Of the Winterberry there is a variety (chrysocarpa) with yellow fruits and of $I$. Sieboldii a variety (fructu-albo) with white fruits. Closely allied to these is the Mountain Holly (Nemopanthus mucronatus), a common shrub in the swampy woods of New England, with dull crimson fruits on slender stalks and neat foliage.

A very attractive small tree is the Chinese Evonymus Bungeanus which bears in great profusion stalked clusters of pink capsules. There are several other Spindletrees with pinkish and reddish fruits, and one that ought to be in every garden is $E$. alatus, a native of the Far East. This is a large, wide-spreading shrub with corky-winged branches and red fruits, and the leaves assume in autumn intense shades of red and crimson.

The lime-loving Buffaloberry (Shepherdia argentea) and S. canadensis, and their relatives the Sea Buckthorn (Hippophae rhamnoides) and the Oleasters, of which the hardiest are Elaeagnus longipes, E. umbellata, $E$. multiflora, and $E$. angustifolia, which is a slender tree with silvery Willow-like leaves, are a group of fascinating plants worthy of the widest recognition. 
ORNAMENTAL FRUITED TREES AND SHRUBS 89

Provided they be given sufficient room to develop, no shrubs are more beautiful in fruit than the Bush Honeysuckles of which there is a great variety. The best with red fruits hails from the Old World and none is more handsome than Lonicera Morrowii, native of northern Japan. This is a fairly large growing shrub with spreading branches and bears in enormous quantities bright crimson berries which ripen in early July and remain on the branches until winter. The common Tatarian Honeysuckle ( $L$. tatarica), which ranges from southern Russia to central Asia and of which there are many varieties, still remains one of the best. Another old and valuable species is L. Ruprechtiana native of northeast continental Asia. Others are L. Xylosteum with winecolored fruits, native of Europe, Asia Minor, and western Siberia and $L$. chrysantha, with lustrous crimson fruits, from northeastern Asia. These five species have long been in cultivation in Europe and this country and have given rise to numerous hybrids more beautiful even than themselves. Among the best of these with red fruits are $L$. muscaviensis and $L$. muendeniensis. The former originated in a nursery at Muskau in Silesia from seeds received from the Petrograd Botanic Gardens and is considered to be a hybrid between L. Ruprechtiana and L. Morrowii. It 
is a large shrub twelve feet high and more in diameter with arching and spreading branches and masses of crimson fruits which ripen early in July. The latter is a mixture of $L$. tatarica, L. Morrowii, and $L$. Ruprechtiana which originated in the Botanic Garden at Muenden in central Germany. It is also a large shrub with erect-spreading branches, rather small leaves, and scarlet berries.

Smaller growing plants with spreading and drooping branches and bright scarlet fruits are L. thibetica, L. syringinantha, and its variety Wolfii from western China. Two other handsome sorts which ripen their dark scarlet fruits late in the fall are L. Maackii from northeastern Asia and its variety podocarpa from central and western China. These are large shrubs ten to fifteen feet tall and as much in diameter.

Many kinds of Barberry have red fruits but none is more handsome than the native Berberis canadensis with pendent masses of scarlet fruits. Almost equally beautiful is the allied $B$. vulgaris. The crimson fruits of the favorite $B$. Thunbergii, which are borne singly from the leaf-axils, are very attractive and so too are the racemose, salmon-red fruits of $B$. sinensis and the red fruits of the vigorous growing $B$. amurensis. A low-growing and decidedly valuable plant for rockeries in particular is the new $B$. Wilsonae from the Chino- 
ORNAMENTAL FRUITED TREES AND SHRUBS 91

Thibetan borderland, which bears globose, brilliant salmon-red fruits.

The Highbush Cranberry (Viburnum americanum) is one of the most conspicuous of red-fruited native shrubs and in this respect is more ornamental than its close allies V. Opulus from Europe and V. Sargentii from northeastern Asia. Two Japanese species ( $V$. Wrightii and V. dilitatum), both medium sized shrubs, ought to be grown for their lovely fruits. The redfruited Elderberry (Sambucus racemosa) of northern Europe and western Asia is also a desirable shrub especially for planting in moist places and by the sides of ponds. Its relative ( $S$. callicarpa) from western North America and northern Japan is, as I saw it in August, 1914, one of the finest of native shrubs in fruit.

The Old World genus Cotoneaster includes some of the most beautiful of all berried plants and many of them are suitable for rockeries. From China, which is the headquarters of the genus, gardens have recently received many valuable additions. Among the best are the low-growing $C$. horizontalis, its smallleaved variety perpusilla, C. adpressa, and the trailing C. Dammeri; of the moderate sized species, C. disticha, C. divaricata, C. hupehensis, C. multiflora, C. racemiflora, C. racemiflora, var. soongorica, C. bullata and its 
variety macrophylla. These are all perfectly hardy shrubs and worthy of a prominent place in every garden. Farther south the evergreen C. salicifolia and its varieties floccosa and rugosa ought to be grown. And so too should be the European Buisson ardent (Pryacantha coccinea), its variety Lalandii, and Chinese relative $P$. crenulata, all with bright scarlet fruits. In China the various kinds of pheasants are very partial to the fruits of these shrubs and those interested in rearing these birds should plant both Cotoneaster and Pyracantha as a source of winter food for them.

\section{ORANGE AND YELLOW FRUITS}

Only a few hardy woody plants have yellow or orange-colored fruits, and a number of these are varieties of types with red fruits, some of which mention has already been made. Among the Bush Honeysuckles are several with yellow or pale orange fruits such as Lonicera Ruprechtiana, var.xanthocarpa, L. tatarica, f. lutea, and L. minutiflora. The lastnamed is a hybrid between $L$. micrantha and $L$. Morrowii and with its translucent pale-orange fruit is one of the most beautiful of the genus. There is also a form of the European Guelder Rose (Viburnum Opulus, var. xanthocarpum) with yellow fruit, and 
ORNAMENTAL FRUITED TREES AND SHRUBS 93

also a number of species of Gooseberry and Currant (Ribes). The American Persimmon (Diospyros virginiana) has orange-colored fruits which become blackish purple when dead ripe.

But if pure yellow and orange are rare colors among fruits they are common in combination with red as in plums, peaches, apricots, cherries, and other comestible fruits. Of ornamental fruited trees and shrubs having fruits red and yellow in varying degrees and shades the most important are the Asiatic Crabapples. However, as a later chapter is devoted to these beautiful plants I refrain from entering into the subject at this time beyond remarking that in fruit they are highly ornamental and that the fruits persist on the branches until spring. Birds are remarkably fond of these fruits and every bird lover should contrive to have a few of these plants in his (or her) garden or on his (or her) estate.

\section{BLACK FRUITS}

This group in size ranks next to that of red fruits, and in many of its members the fruits as they ripen assume various shades of red before becoming finally black. Among trees the Asiatic Corktrees (Phellodendron) bear annually a wealth of shining black fruits. These are quick-growing medium-sized 
perfectly hardy trees with handsome bark, spreading branches, and large dark green pinnate leaves and they are not subject to disease or insect pests. Five species are growing in the Arnold Arboretum: $P$. sachalinense, $P$. Lavallei, and $P$. japonicum from northern Japan, $P$. amurense from northeastern continental Asia and $P$. chinense from central China.

In the Ivy family, besides Kalopanax ricinifolium described in Chapter III, there are many blackfruited plants such as the native Hercules Club (Aralia spinosa) and its Asiatic ally (A. chinensis), with much divided yard-wide leaves and broad clusters of small fruits. Also Acanthopanax sessiliflorum and A. spinosum which are large-growing shrubs with globose heads of fruit, native of northeastern Asia, and the smaller Chinese species A. Henryi. All these love a cool, moist situation. Most of the Rhamnus belong to this group and many of them like $R$. davuricus, $R$. Frangula, and the Common Buckthorn ( $R$. catharticus) fruit profusely and retain their berries far into the winter. A particularly handsome species is $R$. alpinus with large deep green strongly veined leaves and which makes a large bush.

The Canadian Elderberry (Sambucus canadensis), so abundant in moist places throughout New Eng- 
land, and its variety maxima, remarkable for its enormous flat masses of flowers, are very beautiful with their lustrous fruits and so is $S$. pubens of which there is a variety (leucocarpa) with yellowish fruits. A number of Viburnums, both native and exotic, have black fruits and many of them are desirable shrubs. Among the best of the native species are $V$. pubescens, the Arrow-wood ( $V$. acerifolium), and the Hobble Bush ( $V$. alnifolium, often called $V$. lantanoides). The last named is a lovely shrub with large leaves but unfortunately it dislikes cultivation and the same is true of its close ally, $V$. furcatum, from northern Japan. Of exotic species perhaps the best in fruit is the Japanese V. Sieboldii, a large bush or slender tree thirty feet tall, with large, prominently nerved bright green leaves and large pyramidal clusters of jet-black fruit. When it fruits freely the popular $V$. tomentosum (often called $V$. plicatum) from Japan is very beautiful. Other good sorts are the European Wayfaring Tree ( V. Lantana), its Chinese relative $V$. Veitchii, and the evergreen $V$. rhytidophyllum with remarkably long wrinkled leaves felted on the underside. Belonging to the same family are several Bush Honeysuckles with lustrous black fruits of which mention may be made of the European Lonicera nigra, the Chinese L. nervosa, 
and $L$. involucrata from western North America. The last named has jet-black fruit on a fleshy crimson receptacle.

The Privets (Ligustrum) all have black fruits and the hardiest of all and the most beautiful in fruit is the European $L$. vulgare, here and there naturalized in this section of America, and its variety foliosum. These most desirable shrubs have large shining black fruits in clusters and ought to be generally planted in the colder parts of this country in preference to their less hardy Asiatic relations which have dull-colored fruits.

Many members of the great Rose family also belong to this group and in fruit none is more beautiful than the native Chokeberry, (Aronia melanocarpa, its varieties grandifolia and elata, and $A$. atropurpurea.) Another species (A. arbutifolia) has red fruits. Among the Cotoneasters with black fruits are C. vulgaris, C. nitens, C. moupinensis, C. foveolata, C. lucida, C. acutifolia, and its variety villosula, all strong growing, free fruiting shrubs.

The Inkberry (Ilex glabra) and its Japanese relative, $I$. crenata, are two valuable and hardy evergreens with small glossy leaves and stalked black fruits.

Among Barberries most of the evergreen species such as Berberi's Julianae, B. Sargentiana, B. Gagnepainil, 
and $B$. verruculosa have black fruits. The first named is the best of the upright growing species of this group hardy around Boston, Mass., the last named, with prostrate spreading branches and small shining holly-like leaves white on the underside, is a gem for rockeries.

\section{BLOOMY BLACK AND BLUE FRUITS}

In addition to the Blueberries (Vaccinium) with edible fruits quite a number of the best native shrubs have fruits blue-black or black-purple and covered with a protective pale waxy bloom, and many of these before attaining their final hue pass through stages of red and crimson. Foremost in this class rank such Viburnums as V. Canbyi, V. dentatum, V. prunifolium, V. rufidulum, V. lentago, and V. cassinoides. All are handsome in flower, foliage, and fruit and are strong-growing shrubs which cannot be too highly praised for planting in the parks and gardens of the colder parts of this country. In the last named the fruits change from green to pure pink and finally to blue-black, and it is one of the most lovely of all shrubs.

The pinnate-leaved Barberries (Mahonia) are a charming group unfortunately not very hardy. The hardiest is the low-growing $M$. repens with grayish 
green leaves, but the most popular is $M$. Aquifolium with glossy leaves which assume fine tints in early winter; the Japanese $M$. japonica is the most vigorous grower and has the largest leaves. All have terminal bunches of beautiful grape-like fruits. The lovely Berberis stenophylla, a hybrid between two South American species, with slender arching stems and small dark green leaves and perhaps the finest of all the Barberries, is, alas! not quite hardy around Boston, Mass.

The blue-fruited Bush Honeysuckle (L. coerulea) with teat-like fruits which ripen in June is a very valuable shrub. This plant grows wild in various parts of the cold north temperate regions of both hemispheres and is very variable. The American variety (villosa) has palatable edible fruits but the Asiatic varieties altaica and graciliflora with bitter fruits are more ornamental garden shrubs.

The native Silky Cornel (Cornus Amomum) and its close relative $C$. obliqua are large-growing shrubs with blue fruits. A plant that deserves the widest recognition is Symplocos paniculata (better known as S. crataegoides) with turquoise-blue fruits. This is a large bush or slender tree and is very common in Japan, Korea, and China. It is perfectly hardy around Boston, Mass., has good foliage, small clusters of white 
flowers with conspicuous stamens, and in the autumn it fruits profusely.

\section{WHITE FRUITS}

The most attractive mempers of this group are the native Snowberry Bushes (Symphoricarpos) and the Dogwoods or Cornels (Cornus). The former are low twiggy plants with small gray-green leaves, insignificant pink flowers, and large snow-white berries. The best are $S$. racemosus and its variety laevigatus, $C$. oreophilus, C. occidentalis from the northern middle states, C. Heyeri from Colorado, and S. mollis from California. Another species, familiarly known as the Coralberry (S. orbiculatus), has red-purple fruits and is very attractive around Christmas time. Among the best of the white-fruited Cornels are the native Cornus racemosa (better known as $C$. candidissima), a twiggy shrub of moderate size; C. circinata (often called $C$. rugosa), which is a large bush or low tree with red foot-stalks to the fruits; the hybrid C. Arnoldiana, which is a fair-sized shrub; and C. stolonifera, the Old World C. alba and C. sanguinea, too well known to need description. A Bush Honeysuckle (Lonicera quinquelocularis) with white or yellowish translucent fruits in which the black seeds are clearly visible is also worthy of note. 
In the south and in California Pernettya mucronata from the Magellanic region of South America, and $P$. rupicola from Chile ought to be grown. These are low-growing bushy shrubs and of the former there are many fine garden varieties. 


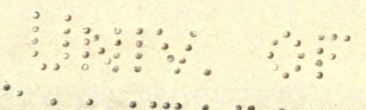
$\therefore$ a 


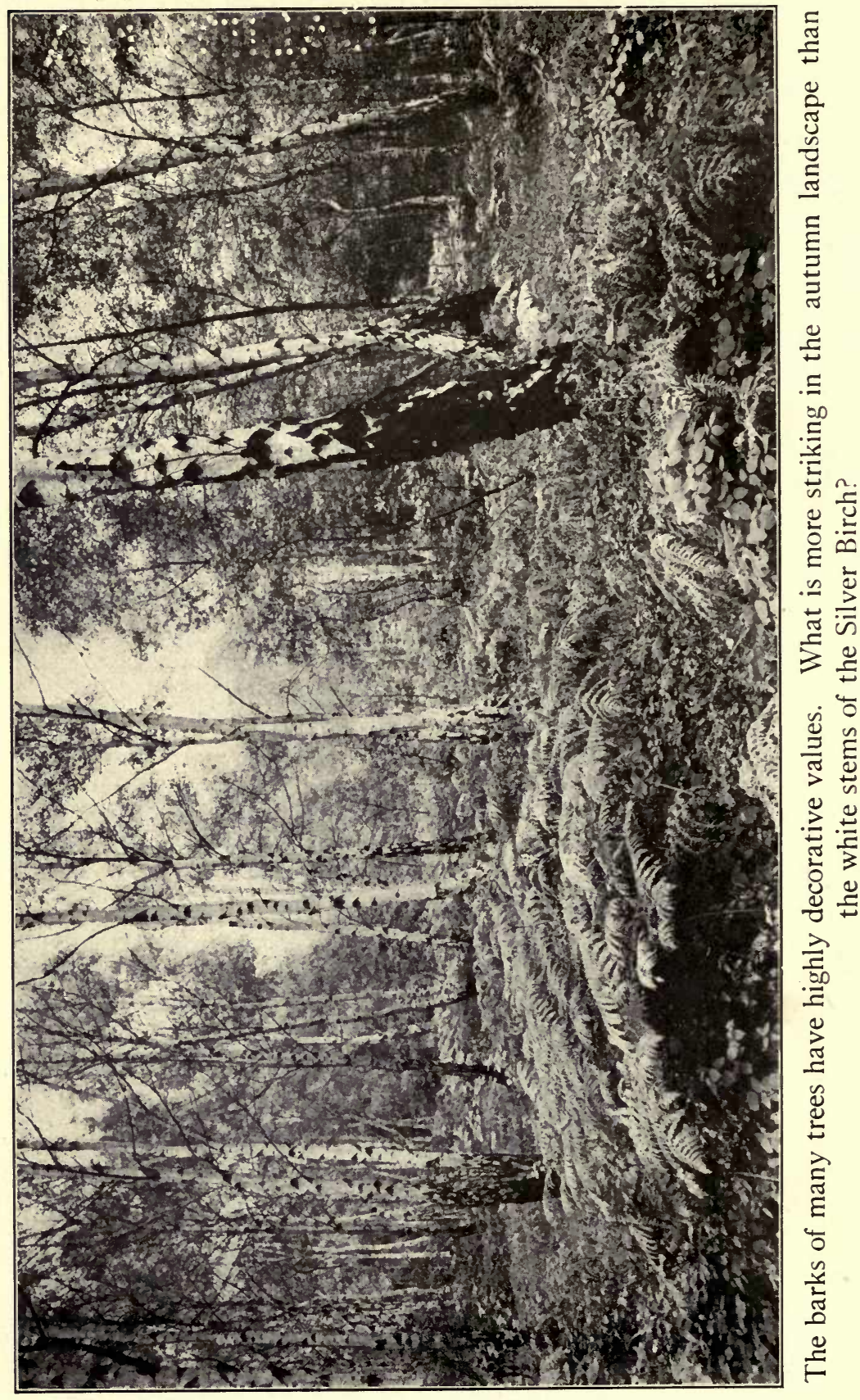




\section{CHAPTER VI \\ THE GLORY OF THE AUTUMN}

THE WONDERFUL COLORING OF THE PASSING LEAVES, AND WHAT IT MEANS

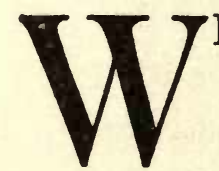

HEN the beauty of the Aster displaces that of the Goldenrod in September; when blue and purple transcend the yellow in field and border; the deep green mantle of foliage draping hill and dale, mountain and ravine, streamside and roadside, commences to show signs of portentous change. The Pines, the Hemlocks, and their kin look even darker as the contrast with their deciduousleaved neighbors becomes stronger. In the swamps about the last week of August and at the first whiff of autumn in the air the Red Maple begins to assume a purplish tint and its example is soon followed by other kinds of trees. To all of us the season of the year becomes apparent, warning signs of stern winter's approach increase rapidly and soon the whole country puts on its gayest mantle of color. The peoples of the tropics, where monsoon rains are followed by burning heat and where the young unfolding 
leaves of many forest trees are brightly colored, never enjoy the wonderful feast of color displayed in the forests and countrysides of this and other northern continental areas. They have other things of which we may envy them but autumn tints are peculiarly our own. The brightly colored Codiaeums of the tropics and our hot-houses (where they are erroneously called Crotons), beautiful as they are, do not equal the Red Maple, Sugar Maple, Sassafras, and Tulip Tree in the fall. No scene in nature is more delightful than the woods of eastern North America in the fulness of their autumn splendor.

It is a weakness of humans to crave most those things beyond their immediate reach, but the wise among us are content to enjoy those which fall within the sphere of everyday life. To revel in the splendid riot of autumn color no long journey has to be undertaken. It is at our very door. From the St. Lawrence Valley and the Canadian Lakes southward to the Alleghany Mountains there is displayed each autumn a scene of entrancing beauty not surpassed the world over. Central Europe, Japan, China, and other parts of eastern Asia have their own season of autumn color and each area has its individuality but, if they rival, they cannot surpass the forest scenes of eastern North America. 
But wherefore and why all this gay autumnal apparel? Is it the handiwork of the charming fairies and wood nymphs of our childhood beliefs and nursery days? Surely some guiding hand, some beneficent agency, some lover of mankind must have prepared the scene as the final tableau of the seasons! The talent of the Master Artist is unveiled and the picture surpasses the dreams of those who live in lessfavored areas of the world.

Those skilled in the mysteries of organic chemistry and plant physiology tell us that autumn tints are due to chemical changes associated with the storing away of food material and the discharge of certain waste products. This explanation, though matter of fact and disturbing to our youthful belief in fairies and wood nymphs, opens up a field of inquiry which must tend to enlarge our viewpoint and increase our appreciation of Nature's wonderful methods. We find that all is governed by laws which act and react in such manner as to ensure the end and object desired.

Now briefly the autumn metamorphosis is effected as follows:

At the approach of winter, leaves which cannot withstand frost cease their function as food factories; and the various food substances are conveyed from 
the leaf-blade into the woody branches or subterranean rootstock and there stored, chiefly in the form of starch, until the season of growth re-commences the following spring. The leaves from which everything useful has been transported form nothing more than a framework of cell-chambers containing merely waste products, like crystals of calcium oxalate, which are thrown off with the leaves and help to enrich the soil. But while the process of food evacuation is going on other changes take place. In many plants a chemical substance known technically as anthocyanin is produced in the leaves, and often to such an extent as to become plainly visible on the exterior. It appears red in the presence of free acids in the cell-sap, blue when no acids are present, and violet when the quantity of acids is small. In a great many leaves the bodies which contain the green coloring matter become changed to yellow granules while the evacuation of food substances is in process. Sometimes these granules are very few and anthocyanin is absent; then the leaf exhibits little outward change except losing its freshness before it falls. In others the yellow granules are abundantly developed and if anthocyanin is absent, or nearly so, the whole leaf assumes a clear yellow hue. If there is an abundance of yellow granules together with 
free acids and anthocyanin, the leaf assumes an orange color. Thus the leaf at the period of autumnal change, by the presence of these substances in a greater or lesser degree, loses its green hue and becomes brown or yellow, crimson or orange, purple or red. The play of color is greater according to the number of species and individuals associated together in a particular spot. But the greatest display of color is seen when the neighborhood is sprinkled with plants having evergreen foliage, when it often happens that a relatively small area of woodland and meadow appears decked in all the colors of the rainbow.

The most casual observer knows that all trees and shrubs do not assume tinted foliage in autumn. Some, like the Alder, the Locust (Robinia), the Elder, and most Willows, exhibit little or no change save perhaps a number of yellow leaves scattered through the green before they fall. But this group is relatively small and only adds additional contrast to the landscape. Again, plants whose leaves are covered with silky or woolly hairs or with a felted mat of hairs never present any autumn coloring, and in those in which the green color disappears the change is to pale gray and white.

In a rather large group of trees, which includes 
the Walnut, Butternut, Catalpa, Elm, Hickory, Chestnut, Horsechestnut, Linden, Buttontree, White Birch, and others, the tints are a general mixture of rusty green and yellow and under favorable circumstances occasionally pure yellow. In the Poplar, Tulip-tree, Honey-locust (Gleditsia), Mulberry, Maidenhair-tree (Ginkgo), Beech, and most of the Birches, the leaves change to pure yellow of different shades. In none of the above-mentioned groups is purple or red of any shade developed.

In favorable years the American or White Ash (Fraxinus americana) is unique in its tints, passing through all shades from a dark chocolate to violet, clear brown, and salmon but it has no reds.

The Peach, Plum, Pear, Apple, Quince, Cherry, :Mountain Ash (Sorbus), Hawthorn, Silver Maple, Wild Roses, and Brambles (Rubus) have a predominance of green with a slight or considerable admixture of purple, red, and yellow, and individuals are frequently strikingly brilliant. In another group purple, crimson, and scarlet with only a slight admixture of yellow, if any, obtains. Here belong the Tupelo, Scarlet Oak, White Oak, Poison Ivy, Virginia Creeper, Sumach, Viburnum, Sourwood, Cornel, Blueberries, and many other plants. A final group, to which belong the Red, Sugar, Striped, and Moun- 
tain Maples, Smoke-tree (Cotinus), Poison Dogwood, Sassafras, and the Shadbush or Snowy Mespilus, has variegated tints comprising all shades of purple, crimson, scarlet, orange, and yellow on the same or different individuals of the same species. Often the leaves are tinted and sometimes figured like the wings of a butterfly.

Careful observers will note that the gradations of autumn tints in all cases are in order of those of sunrise, from darker to lighter hues, and never the reverse. The brown leaves which long persist on some trees (Beech, Chestnut, and certain Oaks for example), though darker than the yellow or orange from which they often turn, are no exception since these leaves are dead and the brown is only assumed after vitality has vanished.

Some species are perfectly uniform in their colors; others, on the contrary, display a very wide range. For example, the Maidenhair-tree, the Tulip-tree, and Birch are invariably yellow; the Virginia Creeper, Sumach, and White Oak chiefly red; while Maples are of as many colors as if they were of different species. But each individual tree shows nearly the same tints every year, even as an Apple Tree bears fruit of the same color from year to year.

The Red Maple (Acer rubrum), so abundant in 
swamp and wood, roadside and on dry hilltop, is the crowning glory of a New England autumn. By the last week of August it commences to assume a purplish tint; sometimes a solitary branch is tinted, frequently the coloring process begins at the top of the tree and the purple crown of autumn is placed on the green brow of summer. Trees growing side by side are seldom alike, and in a group may be seen almost as many shades of color as there are trees. Some are entirely yellow, others scarlet, some crimson, purple, or orange, others variegated with several of these colors. Indeed, on different individuals in the Red Maple may be seen all the hues that are ever displayed in the autumn woods. The Sugar Maple (Acer saccharum), though more brilliant, has a narrower range of color and is more uniform in its tints which range from yellow and orange to scarlet.

The common Tupelo (Nyssa sylvatica) more invariably shows a mass of unmixed crimson than any other New England tree. The foliage first assumes shades of purple which change into crimson or scarlet before it falls.

The Oaks, the noblest group of trees in eastern North America, assume their autumn tints very late and are not at their zenith until after the Maples have passed. In the Scarlet, Red, and White Oaks the tints 
are ruddy, varying from reddish purple and crimson to pale red; and when at their best, after the middle of October, these trees are the most beautiful of the forests or pastures. The Black and Swamp Oaks develop imperfect shades of orange to leather-colored tints.

In the White Oak, the Beech, the Chestnut, and the Red Oak when young the leaves as they die become russet-brown and remain on the trees until the spring and give a sensation of warmth to the woods and landscape in the coldest days of winter. The period of retention varies greatly in different individuals; often the leaves are retained on the lower branches when the upper parts of the tree are bare.

In England, trees with few exceptions, such as the wild Cherries and the Beech, assume no autumn tints comparable with those of their North American relatives. Indeed, in England the most varied and brightly colored tints are found not on the native trees but on the Brambles (Rubus). Long ago European trees were planted in this section of America and some, like the Elm, Linden, and English Oak, have grown to a large or moderately large size. In autumn such trees stand out very clearly with their mantle of green foliage when the native trees present are all tints or have shed their leaves. These colonists preserve their 
green hues until late into October when finally the leaves become mottled, yellowish or brownish and fall.

Asiatic trees and shrubs cultivated here assume their wonted tints and so also do those of central Europe. The trees of Japan and China color with us rather later than the native trees and lengthen the season fully two weeks.

Whilst I have dealt primarily with trees as the principal objects of admiration in autumnal scenery, I must not omit mention of the shrubs which clothe the wayside and forest floor, or the climbers which drape both bushes and trees or form tangled thickets of themselves. It is true that there are more of these than there are of trees which do not change color materially but remain green until the fall of the leaves. But a great many do change very materially, and it is interesting to note that reds predominate in the shrubs and yellows in the trees. Reds and purples distinguish the Cornels, Sumachs, Poison Ivy, Viburnums, Virginia Creepers, Fox Grape and others, and yellow the Spicebush. Indeed, there is so small a proportion of yellow in the shrubbery that it is hardly distinguishable in the general mass of scarlet, crimson, and purple which forms so marked a contrast with the unchanged greens of many associate shrubs. In mis- 
cellaneous mixed woods, on the contrary, yellow prevails among trees.

In Japan, where an intense love of nature is innate among all classes, there prevails a custom which might well be adopted here. The beauty spots in that land are many and are justly celebrated in poetry and song: august Fuji with its perfect cone and snowy mantle; the Pineclad islets of Matsushima; the Inland Sea with its hundreds of islands clad with verdure to the water's edge; the Nikko region with its mountains and lakes, its waterfalls and woods; and hundreds of other places more or less famous, including many noted for their Maples. In October, when the woods assume their autumn splendor, children from primary and secondary schools, high schools and colleges, with their teachers and professors, make excursions of three or four days' duration to noted places and revel in the feast of color. The railways issue cheap tickets and from all the large towns and cities children, youths, and maidens journey to the mountain woods. Last autumn in the Nikko region I saw thousands of scholars-boys and girls varying from eight to twenty years of age (and a happy, orderly throng they were)-enjoying to the full the scenery, breathing in the freshest mountain air, and building up healthy minds and bodies. Their joy- 
ousness was wholesomely infectious and it was good to mingle with them. As I look back on the many pleasant experiences I enjoyed in that pretty land none gives me greater pleasure than the memories of those throngs of happy scholars in the woods and woodland paths of Nikko, Chuzenji, and Yumoto.

Autumn tints is a subject that belongs more especially to the sphere of the artist than to that of the scientist. The poet can sing their song more easily than a writer of prose can describe their beauty, but on equal plane with all the common folk can enjoy the splendor of the autumn colors. Let us then at autumn time lay aside for a brief moment the cares of daily life, break away from engrossing tasks of every kind and linger for a while among the trees and shrubs of the roadside and woodland, drink in cool draughts of fresh air, and revel in the galaxy of color that beneficent Nature so lavishly displays on every side. 


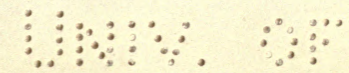

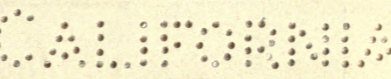




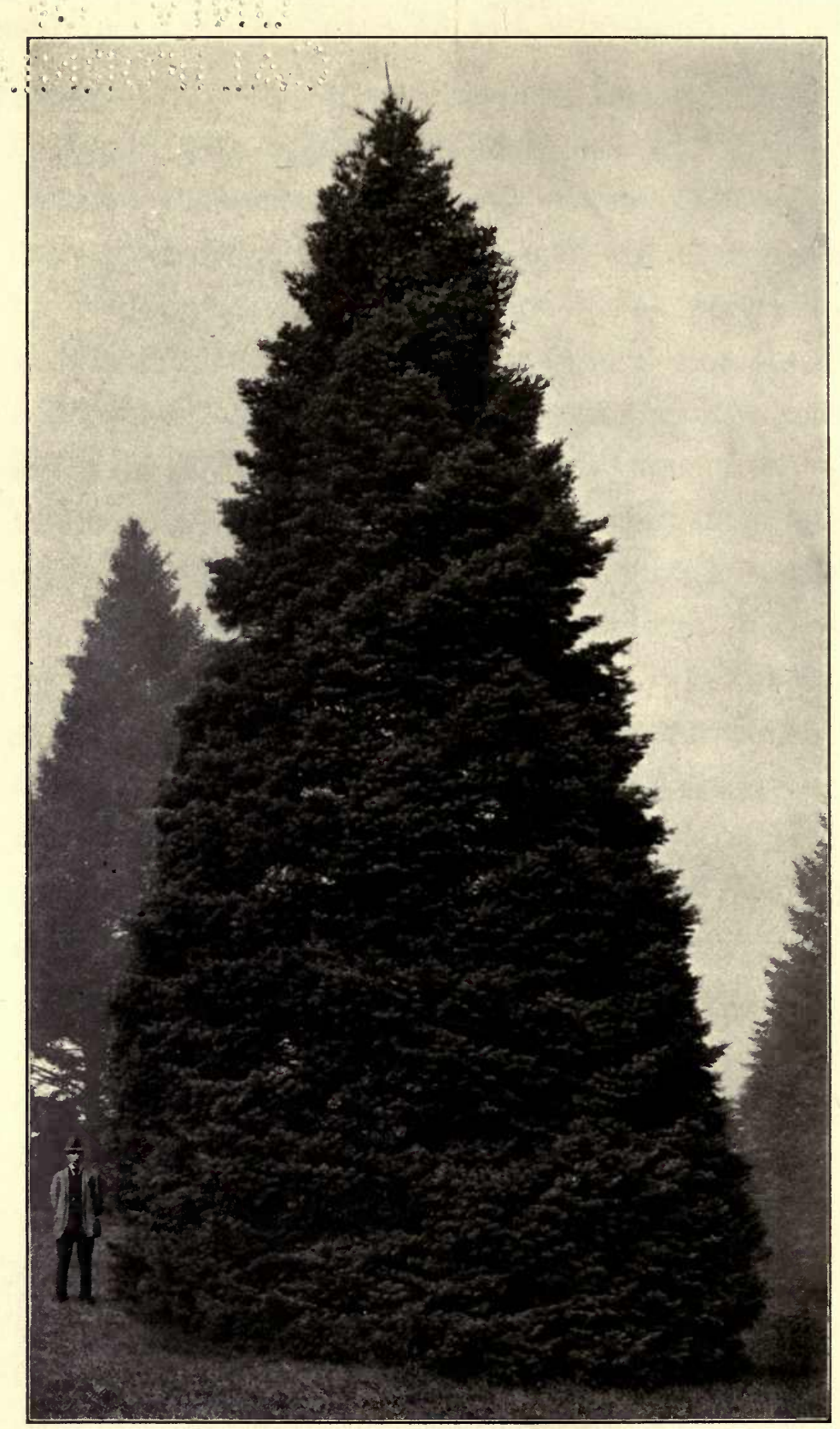

As a lawn tree and for ornamental planting generally the concolor Fir is the most beautiful of conifers, retaining its decorative form for very many years 


\section{CHAPTER VII \\ THE BEST HARDY CONIFERS}

SOME PLAIN FACTS CONGERNING CERTAIN WELL-KNOWN TREES WHICH EXPERIENCE PROVES TO BE OVERRATED. THE BEST FEW FOR GENERAL USE

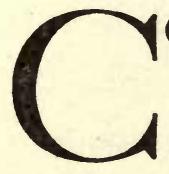

ONIFERS rank among the patriarchs of the vegetable kingdom and in their size, their beauty, and their usefulness to man they are not surpassed by any other family of trees. In a general way every one is acquainted with these conebearing plants and they are universal favorites. The family is distributed from the Arctic Circle nearly to that of the Antarctic, and its members are abundant in the temperate regions of both Hemispheres but they are rare within the tropics. One genus only, Libocedrus (Incense Cedar), is common to the Northern and Southern Hemispheres. In longevity and massiveness of bulk, the Redwoods of California (Sequoia) exceed all other trees, and in height these giant Conifers are only approached by the broadleaved Blue Gums (Eucalyptus) of Australia. With exception of the Larch (Larix), the Chinese Golden Larch (Pseudolarix), the Swamp Cypress (Taxodium) 
and its Chinese relative (Glyptostrobus), all Conifers are evergreen; and it is this character, together with their noble aspect, that makes them horticulturally of such supreme importance. No other tree or shrub gives quite the same effect or adds so much restful dignity to northern landscapes. Although the family is so universally distributed, many of its members are fastidious in their requirements and only a limited number thrive in the rigorous climate of New England, where hot dry summers and cold winters are the rule and where, in March, hot sun and drying winds by day are followed by low temperatures at night. Such conditions are most inimical; nevertheless, the White Pine (Pinus Strobus) and the Hemlock (Tsuga canadensis), two of the handsomest of coniferous trees, are native of that region, and where these thrive the lovers of evergreen trees need not lack material for their plantations.

In the early days of horticulture in this country it was customary to import from Europe nearly everything required-even trees and shrubs native of this country. On the whole this experiment has not proved a success and in the matter of hardy trees (especially Conifers) has occasioned much disappointment. However, the failures and successes of the past are, if rightly appreciated, a wholesome 
lesson to the present generation of garden lovers since the benefits are theirs to enjoy. For the work of proving what trees and shrubs, coniferous or otherwise, will thrive here we owe a lasting debt to the arboreta, to the owners of estates, and to the nurserymen who have labored in this field. Much remains to be done; but enough has been accomplished to enable us at least to avoid some of the mistakes of the past.

In the Arnold Arboretum, Boston, Mass., there is growing the largest collection of species and varieties of Conifers to be found anywhere on this continent, and for more than forty years the work of getting this collection together and developing it has been continuously maintained. In general it has been found that the Conifers of northeastern North America, the Rocky Mountains, northern, central, and southeastern Europe, Siberia, northern China and northern Japan, are hardy; that only a few of the species of western North America can be safely planted here; and that those of the southern United States, Mexico, Central America, southern China, Formosa, the Himalayas, southeastern Asia and the Southern Hemisphere in total are not hardy in New England. Furthermore, not all the varieties that are hardy thrive equally well, and many cannot with con- 
fidence be recommended for purposes of general landscape planting. The more ornamental of those which the experience of the Arnold Arboretum has proven to be adapted to this climate I now propose cursorily to mention.

As a lawn tree and for ornamental planting generally, the best Fir and one of the most beautiful of all Conifers is Abies concolor, native of the southern Rockies from Pike's Peak in Colorado to the Shasta Mountains in California where it grows two hundred and fifty feet tall. The Colorado form in particular is very hardy, though rarely found exceeding one hundred feet in height. It is a tree of moderately rapid growth, with leaves pale graygreen on both surfaces and flat-spreading branches in tabuliform tiers close set one above the other, gradually diminishing in length from the base to the summit. The outline is conical and the branches are long retained, and on trees forty years of age sweep the ground and promise to do so for many years to come.

A worthy companion to $A$. concolor is the Japanese A. homolepis, or A. brachyphylla as it is more usually called. In Japan this tree grows one hundred feet tall and has massive branches which form a broad flattened or rounded head, and such trees in aspect resemble old 
specimens of the Cedar of Lebanon. Young trees in habit resemble those of $A$. concolor, but the branches are more narrow and tapering and rather less densely arranged. The leaves are grass-green above and silvery white below. These two Firs are excellent companions, forming a striking contrast in foliage, and to admit of their full development they should be allowed a radius of not less than twenty-five feet.

In New England Abies cilicica from the mountains of Asia Minor, A. Nordmanniana from the Caucasus, and $A$. cephalonica from Mount Enos in the Grecian Archipelago are of about the same value. Seldom do they thrive equally well in the same locality, one or other usually having the advantage. In Great Britain the Cilician Fir thrives, but is rare, whereas the Nordmann Fir is unsatisfactory as it grows old. In appearance these handsome Firs are very similar, being narrow conical in outline with rigid, horizontally spreading pointed branches and leaves dark glossy green above and silvery white beneath.

Another Fir which thrives very well here is Veitch's (A. Veitchii), native of the mountains of central Japan. In a wild state this is a slender tree seldom exceeding seventy-five feet in height, with thin, short, spreading branches which form a narrow crown. In cultivation 
the branches are longer than in the wild trees and often slightly ascending. The leaves are soft to the touch, dark green above and silvery below.

The Firs delight in a cool soil and climate, but some, like $A$. concolor, are not exacting and withstand drought and dry situations very well. All are intolerant of smoke and soot and for this reason do not thrive in cities or near manufacturing centres. These remarks apply also to the Spruces, although they are slightly less exacting in these matters.

The Douglas Fir (Pseudotsuga taxifolia) is one of the loftiest and most valuable of all coniferous trees and, from a horticultural viewpoint, one of the most indispensable. It has an immense range of distribution in the western parts of North America and attains its maximum development in the wet regions bordering the Puget Sound and on the western slopes of the Sierra Nevada, where trees three hundred feet tall with trunks nine to twelve feet in diameter occur. This tree was discovered on the shores of the Nootka Sound by Archibald Menzies in 1792, during Vancouver's voyage round the world, was rediscovered by David Douglas in 1827, and introduced into England by him the following year. In the mild, moist climate of Great Britain this tree of the Pacific slope soon made itself at home and in most parts of that land it grows 
rapidly. From Britain it was introduced into eastern North America, but in the colder parts of this country it proved to be not hardy. In 1862, it was most fortunately discovered at high elevations in Colorado, and seeds from this source have given us a race of perfectly hardy and quick-growing trees. In the Arnold Arboretum trees forty years of age are fifty feet and more tall, and others about fifteen years old are eighteen to twenty-five feet tall. The lower branches of these trees sweep the ground and the others are inclined upward and have a plume-like appearance. The leaves vary from dark green to glaucous.

The uninitiated may distinguish this tree from all other Conifers by its relatively long, conical, sharppointed winter buds. Either as a lawn tree, or for avenues, or for massing, Douglas Fir is equally valuuable and it needs no recommendation.

Perhaps no Conifer has been received into popular favor more readily than the Colorado Blue Spruce (Picea pungens), and certainly none has been more extensively planted. Lately there has been some outcry against it, but as a young tree it is undeniably beautiful. It has taken very kindly to cultivation and is very hardy. One cannot object to it on the lawns of suburban gardens or even on those of country estates; but the indiscriminate manner in which it has 
been planted by the carload in groups and rows on large estates is certainly an offense against good taste. This Blue Spruce grows fairly rapidly and when young is compact, symmetrical, and handsome; but at an early age it loses its lower branches and later becomes unsightly. In the Arnold Arboretum there is growing a tree raised from seeds collected by Dr. Parry when he discovered this Spruce in 1862. This example has lost all its lower limbs and has now only a cluster of branches near the top and is very far from being an object of beauty. Authorities who have seen this Blue Spruce growing wild near the banks of streams in Colorado tell us that it naturally behaves in this manner. Those contemplating planting this tree for permanent effect will do well to bear these facts in mind.

Another tree that has been very extensively planted is the Norway Spruce ( $P$. Abies or P. excelsa). This has proved both accommodating and quick growing, but in New England, where exposed to the winds, the tops of the trees become thin and bare. Most of the older trees exhibit this failing and there seems little likelihood of it being a longlived subject on this side of the Atlantic. However, up to thirty or forty years of age it thrives. The branches are wide-spreading, with the lower 
ones bending downward and sweeping the ground and the uppermost slightly inclined upward, and all have pendent, whip-like branchlets. The leaves are dark green and the aspect of the tree, though decidedly sombre, is graceful.

For the colder parts of this country one of the best of all Spruces is the Canadian or White Spruce ( $P$. canadensis). This is one of the hardiest of all trees and is useful in ornamental and landscape planting generally, but is especially so in situations where other and less hardy coniferous trees will not grow. It is a rather small tree and in the open it is conical in outline and well furnished with branches from the ground upward. The leaves are short, green, and slightly glaucous.

Another valuable species is Engelmann's Spruce (P. Engelmannii), which hails from Colorado and has somewhat the appearance of the common Blue Spruce but the branches are shorter and flatter and the leaves smaller and less glaucous. Specimens in the Arnold Arboretum thirty-five years old are narrow, compact, symmetrical pyramids, but unfortunately they are beginning to lose their lower branches. The Serbian Spruce ( $P$. omorika), which was discovered only in 1872 , has taken kindly to cultivation here and elsewhere. It grows rapidly and the habit 
is pleasing; but, unfortunately, it is addicted to borers. The leaves are flat, lustrous green above and white beneath.

Lastly, mention must be made of the Oriental Spruce ( $P$. orientalis) which is native of the Caucasus and does very well in many parts of this seaboard. It is a tree of medium size with horizontal spreading branches, the uppermost being slightly ascending. The outline is pyramidal, broken by projecting branches. The leaves at maturity are dark lustrous green. In spring the young shoots are bright yellow and, as they lengthen, the leaves become a soft delicate green, forming a beautiful contrast to the rich coloring of the mature foliage.

In this climate most of the Spruces have weak points, a great many of them lose their lower branches at a comparatively early age, and a number of them suffer from gall-insects. On the whole, they are less satisfactory for ornamental planting than their close allies the Firs.

The common Hemlock (Tsuga canadensis) is certainly one of the finest Conifers for general planting. There are several varieties; the best of these are Sargentiana, which forms a remarkable dense flat-topped bush with pendent branches and branchlets; compacta, a densely branched bush, ovoid in 
outline; microphylla, with loose ascending branches; and pendula, with dense spreading branches pendent at the extremities.

The Carolina Hemlock ( $T$. caroliniana) is native of the Blue Ridge Mountains of north and south Carolina, and of the southern Alleghanies where it was discovered in 1850, by Professor L. R. Gibbes. It was introduced into the Arnold Arboretum in 1881, where it grows freely and gives every promise of being a most desirable and ornamental Conifer. It is a smaller but a more graceful and beautiful tree than its northern confrère.

No trees make a better windbreak than do the Pines, and on lawns and for avenues they are most effective. The native White Pine (Pinus Strobus) is one of the noblest of all Pines and needs neither introduction nor eulogy here. Its confrère, $P$. monticola from western North America, is also perfectly hardy and grows freely in this climate. So also does the Foxtail Pine ( $P$. flexilis), native of Montana, Nevada and other parts of western North America. The White Pine of the Balkan Peninsula ( $P$. peuke), which was discovered in 1839 but was not introduced until 1864, is also quite hardy and grows well in this country. It forms a narrow pyramidal tree densely branched and heavily clothed with bright green leaves. 
Another very satisfactory hardy and highly ornamental tree is the Japanese White Pine ( $P$. parviflora). This species is widely spread in Japan where it grows naturally in steep, rocky country. It is also a favorite tree in Japanese gardens, where it is kept dwarf and trimmed and is also often trained into grotesque shapes. The Japanese graft this tree on their Black Pine ( $P$. Thunbergii), whose remote relationship undoubtedly aids in checking the growth of its leaves and branches. Under cultivation in New England seedling trees and others grafted on the native White Pine are densely branched, and the branches are very long, horizontally spreading, slightly upturned at the ends and abundantly clothed with gray-green leaves. Its habit is different from that of any other Pine.

The Korean Nut Pine ( $P$. koraiensis) also grows well and promises to be a more satisfactory tree here than its ally, the Swiss P. cembra.

The Scots Pine ( $P$. sylvestris) and the Austrian Pine ( $P$. nigra) in the past have been extensively planted in this country. The former has, unfortunately, proved unsatisfactory and the Austrian Pine is inferior to the native Red Pine ( $P$. resinosa). The latter is one of the best of all Pines in this climate, where it ranks among the first half dozen of all Coni- 
fers and where it ought to be planted in preference to any of its relatives. It grows rapidly and in effect is dark and massive.

The Jack Pine ( $P$. Banksiana) and the Scrub Pine $(P$. virginiana) are low-growing species very satisfactory in cold regions. For sea-shore planting the Japanese Black Pine ( $P$. Thunbergii) is to be recommended. This Pine is very variable in habit and naturally assumes weird and picturesque shapes. It is the Pine so commonly depicted on Japanese embroideries, paintings, porcelains and other objects of Japanese art.

Those familiar with gardens in England and other countries of Europe will have noted, probably with envy, the majestic Cedars of Lebanon (Cedrus libani). No tree is more impressive in appearance and no other gives quite the same effect as this Cedar with its thick trunk, massive spreading and flattened or tabular branches, and deep green foliage. The originals of these trees were brought from the famous groves on Mt. Lebanon in Syria, and the oldest in England were planted between 1662 and 1670. The younger trees and those offered for sale by European nurserymen are descendants of these original introductions. Unfortunately, this Cedar is not hardy in New England but occasional trees may 
be seen growing in the neighborhood of New York City and Philadelphia.

The Cedar of Lebanon grows also on the AntiTaurus Mountains in Asia Minor, a region more northern and colder than that of the Lebanon Mountains; and in 1901, the Director of the Arnold Arboretum had seeds collected there and these were sown in 1902. None of the plants raised from these seeds, although planted in exposed situations, has ever suffered and some of them are now from eighteen to twenty feet tall. The experiment promises complete success and there seems every possibility of our enjoying a thriving race of Cedar of Lebanon which will withstand the winter frosts and summer droughts of New England. If this be consummated the boon conferred on our parks and gardens will be inestimable.

Neither the Atlas Cedar (C. atlantica) nor the Deodar (C. deodara) is quite hardy in New England.

The Japanese Umbrella Pine (Sciadopitys verticillata), with long, dark glossy green leaves arranged in whorls, is perhaps the most distinct of all Conifers. It is perfectly hardy and delights in a cool, moist situation. Young trees vary from narrowly to broadly conical in outline and are strikingly beautiful. In Japan this tree has a rather limited distribution 
and grows on rocky slopes mixed with Chamaecyparis obtusa (Retinispora) and other Conifers, and its narrow, plume-like crown is thrust well above its neighbors.

Under the popular but misleading name of Cedar, and to which the better name of Arborvitae should be applied, are grouped a number of valuable and decorative Conifers all of which are much alike when young. In this stage they are either spire-like, columnar, conical or narrow pyramidal in outline and have dense scale-like foliage of varying hues of green. Generally they are regarded as shrubs, but it is well to remember that some of them rank among the largest and most valuable of forest trees. For example: the Giant Arborvitae (Thuja plicata or $T$. gigantea as it is often called) of western North America, in the valley of the Columbia River grows 200 feet tall and has a trunk clean of branches for fully 100 feet. The story of this tree parallels that of the Douglas Fir. It was first discovered on the shores of Nootka Sound by Nèe, who accompanied Malaspina on his voyage round the world (1789-94) but it was not introduced until 1853, when William Lobb sent seeds to Messrs. Veitch, at Exeter, England. Plants from this source were afterward brought to eastern North America but none proved capable 
of withstanding the New England winters. Subsequently this tree was discovered in Idaho. Seeds obtained from that state have furnished us with a perfectly hardy race, which grows freely and possesses all the good qualities of an Arborvitae. The branches are close set, spreading and much ramified at the distal end; the branchlets are slender, often zigzag or curved, and the densely appressed leaves are yellowish green on the exposed side and much darker on the other.

The native Arborvitae or White Cedar ( $T$. occidentalis) is a rather small tree seldom exceeding sixty feet in height and is usually only from thirty to forty feet. The outline is narrow conical or columnar, and the foliage light to dull green. This tree is very hardy, and under cultivation a great many distinct forms have originated, some with yellow and others with white variegation, and a number are low growing and most compact in habit. The dwarf forms will be dealt with later, but it may be stated here that the forms of this tree afford the greatest variety of hardy Arborvitae that we possess.

Among the taller-growing kinds worthy of attention are: Vervaeneana, a smaller and denser tree than the type, with young branchlets deep golden yellow, changing in winter to brownish orange and 
finally to green; Wareana, denser in habit with foliage of a deeper and brighter green than the type; Wareana aurea, with bright golden-yellow branchlets during the growing season; plicata, with short branches and rigid, erect branchlets and brownish green foliage, and its forms argenteo- and aureovariegata with silver and yellow branchlets; lutea, which is pyramidal and columnar in habit with bright yellow and orange-yellow young branchlets; and pendula, with rather slender branches bending downward, tufted branchlets and green foliage.

The Chinese Arborvitae (Thuja orientalis), which is a small tree from twenty-five to thirty feet tall and columnar or pyramidal in outline, is not hardy in New England. It has been in cultivation in Europe since 1752 , and has given rise to many forms which resemble but are not superior to those of the native Arborvitae (T. occidentalis).

Another Arborvitae (Chamaecyparis thyoides), native of the swamps from Maine southward to northern Florida, is very hardy and worthy of recognition. It is a slender tree from sixty to eighty feet tall, with short, thin, spreading branches which form a spire-like crown, and very small scale-like, imbricated dull bluish green leaves, which turn rusty brown in winter. Of late years the so-called dwarf trees of Japan have 
attained wide popularity both in this country and in Europe. One of the commonest of these is an Arborvitae, usually known as Retinispora obtusa nana and correctly as Chamaecyparis obtusa, var. nana. These dwarfed trees are the outcome of Japanese gardeners' skill and this variety is of garden origin; but the type (C. obtusa) is one of the loftiest and most valuable of Japanese forest trees. At maturity it is one hundred and fifty feet and more tall, with a large clean trunk and wide-spreading branches forming a rounded or flattened crown; but in a young state the branches are slender and flat and spread horizontally; the outline is narrow pyramidal and the effect light and graceful. The leaves are dark green. This beautiful Conifer is perfectly hardy in New England and nurserymen would do well to procure a stock of seeds and raise it in quantity. In Japan it is very extensively used for reafforestation. Its close ally (C. pisifera) is equally hardy and, when young, very distinct with its ascending-spreading, rather plumose branches. At maturity, however, it is not easily distinguished from C. obtusa, which it equals in size and approximates in the value of its timber.

Like other Arborvitaes the Japanese kinds have given rise to numerous forms variegated and otherwise. Those of $C$. obtusa are all low-growing, but 
most of those of $C$. pisifera grow tall. Among the best of these are: aurea, in which the whole of the current season's growth is rich golden yellow and changes to green the following year; sulphurea, similar but of a paler hue; plumosa, very dense in habit and strictly conical in outline and with dark green leaves; plumosa albo-picta has the tips of the branchlets creamy white; in plumosa argentea nearly the whole of the young growths are creamy white and become green the following year; in plumosa aurea they are light golden yellow changing as the season advances to deep green; squarrosa is irregular in outline, densely and intricately branched, and has short, pointed, pale bluish green leaves.

Thus far I have dealt only with tall-growing Conifers but in gardens large and small there is a demand for low-growing sorts and particularly since there are so very few broad-leaved evergreens hardy in this climate. Fortunately, among Conifers there are dwarfs in great variety, some of them sports from free forms and others good species. Of the White Pine (Pinus Strobus) there is a variety (nana) which is a small, compact, roundish, bushy shrub with short slender branches and leaves shorter than in the type. The common and variable Mountain Pine of the Alps and other parts of Europe (P. montana, often known 
as $P$. pumilio or $P$. mughus) is well known and highly esteemed; but the Japanese Table Pine ( $P$. densiflora, var. umbraculifera) deserves wider recognition for it is one of the best of the low-growing Pines. This is a round or broadly oval bush with thin branches and gray-green leaves and is common in gardens in Japan, where it is known as Tanyosho. Another, and dwarfer form, is known as Bandaisho.

Among Spruces, perhaps the best dwarf is Picea Abies, var. Clanbrassiliana, a low-growing, dense and compact shrub with bright green leaves. Another good variety of this Spruce is Gregoryana, which seldom grows more than one to two feet high and is very dense in habit. Other good sorts are nana, Elwangeri, pumila, and procumbens. Of the common Blue Spruce ( $P$. pungens) there is a dwarf variety which makes a round-headed bush.

The greatest variety in dwarf or low-growing Conifers is found among the Junipers and the Arborvitaes. Among Junipers which make an excellent ground cover are J.chinensis, var. Sargentii and J. procumbens from Japan, J. squamata from China, and $J$. horizontalis common near the sea in parts of Maine and elsewhere and one of the most beautiful of all with its blue-green foliage and charming habit. As bushes, distinct and attractive in habit, $J$. chinensis, 
var. Pfitzeriana with bluish green foliage and $J$. virginiana, var. tripartita have much to recommend them.

Among the dwarf forms of the Japanese Arborvitae (commonly called Retinispora) the best are Chamaecyparis pisifera, var. filifera, with thread-like pendent branchlets, and its golden form aurea; Chamaecyparis obtusa, var. gracilis; the var. nana, one of the handsomest of all, and its form aurea. The variety leptoclada of the native Chamaecyparis thyoides is a pleasing shrub but the majority of our dwarf Arborvitae are forms of the native Thuja occidentalis. Among the best of these are umbraculifera, recurva nana, Tom Thumb, Woodwardii, Reedii and Little Gem, the last named perhaps the finest of them all.

The Junipers are usually regarded as shrubs of low growth but some are trees of some magnitude, though only two or three of these are hardy here. The common Red Cedar (Juniperus virginiana), so characteristic of open landscapes in eastern North America, needs no introduction. When young it is usually columnar in outline; the leaves vary from green to glaucous and there are numerous varieties, some of them variegated.

The Chinese Juniper (J. chinensis) is a tree from fifty to sixty feet tall at maturity, when it is broadly pyra- 
midal in outline and very densely branched. When young it varies from columnar to conical. It is perfectly hardy and may be recognized by the branchlets bearing two forms of leaves. Another valuable Juniper is $J$. rigida from Mandshuria, Korea, and Japan. This has long, needle-shaped, pungent leaves, spreading or pendent branchlets, and is columnar or narrow conical in outline. Very similar to the last named is the tree form of the Common Juniper ( $J$. communis) and its variety oblonga, with rather pendulous branchlets. Junipers often suffer from attacks of red spider and should be sprayed occasionally with some antidote.

The Larches are valuable timber trees and all have deciduous leaves, which as they unfold in the spring, are a peculiarly vivid green. The native Tamarack or Hackmatack (L. laricina), although a denizen of swamps, also grows well on dry hillsides. The European Larir. decidua and the Japanese L. Kaempferi have also proved adaptable to this climate.

A tree deserving of wider recognition in this country is the Chinese Golden Larch (Pseudolarix Kaempferi). It is perfectly hardy and very ornamental and in every way a most suitable subject for lawns and parks. The branches are long and spread horizontally; the relatively long, pea-green leaves are deciduous and assume 
in the fall clear yellow tints. In the Hunnewell Pinetum at Wellesley, Mass., there is growing a particularly fine specimen which has ripened perfect seeds. This tree is a native of eastern China south of the Yangtsze River but very little is known concerning its appearance in a wild state, notwithstanding the fact that it has been known since 1804 .

Although properly speaking not Conifers, the Maidenhair-tree (Ginkgo biloba), the Yews (Taxus), and their allies are usually associated with that family in the popular mind and for horticultural purposes may be so considered. In some respects the Ginkgo is the most interesting of living trees since it is a relic of an ancient flora which flourished during the Mesozoic Age. Fossil remains, apparently identical with the living tree, have been found in western North America, in Greenland, in the London clays of England, and elsewhere. At one time it was probably common in north temperate lands of both Old and New Worlds but to-day it no longer exists in a wild state and we owe its preservation to the religious sanctuaries of China and Japan. It is a very hardy, quickgrowing, long-lived tree, attaining a height of one hundred feet with a trunk twenty feet in girth and thrives equally well in city or countryside. Its outline is rather variable but usually it has rather long, spreading 
branches slightly inclined upward and each, when laden with foliage, somewhat plumose in appearance. The leaves are deciduous and resemble closely the leaflets of the Maidenhair Fern and in the autumn change to pure yellow before they fall. This noble tree is unlike any other and none exceeds it in beauty or dignity.

The English Yew (Taxus baccata) and its varieties brown badly during our winters and are not really hardy in Massachusetts; and the native Yew ( $T$. canadensis) of woodland swamps often suffers in the same way when planted in open situations. The Japanese Yew ( $T$. cuspidata), on the contrary, keeps its color unimpaired and is the Yew par excellence for New England gardens. An eminent authority maintains that this is the most valuable plant that Japan has contributed to New England gardens, and few, if any, will attempt to gainsay this. The foliage is blackish green and the plant is handsome on lawns and makes an excellent hedge. Most of the plants in cultivation have been raised from cuttings and only occasional examples show signs of developing into trees. When raised from seeds, however, a distinct leader is usually developed from the beginning.

In Japan this Yew has a very wide distribution and grows in moist forests in the extreme north of Hok- 
kaido. At its best it is a shapely tree fifty feet tall with a thick trunk and wide spreading branches, but on exposed mountain slopes it is reduced to a low shrub. In cultivation there is a dwarf variety (nana) with wide-spreading branches which possesses all the good qualities of the type and is most suitable for planting when low evergreen shrubs are desired. 


\section{CHAPTER VIII}

\section{BROAD-LEAVED EVERGREENS FOR NORTH- ERN GARDENS}

THE PLANTS OF THIS CLASS THAT CAN BE GROWN ARE COMPARATIVELY FEW BUT INCLUDE SOME GOOD NATIVES

N THE late autumn and throughout the winter,
the gardens of New England present a marked
contrast to those of Old England in that their habitants, save the Conifers and the Yews, are bare of leaves. There is a nakedness about our gardens which emphasizes the dreariness of the winter season. We have so few hardy, broad-leaved evergreen shrubs, and no trees; whereas in Great Britain they have many and there is a greenness and freshness about their gardens at all seasons of the year. We cannot help envying them their good fortune in being able to grow out of doors and with no trouble a wealth of plants which are ever clothed in restful green. Climate alone is responsible and since this is beyond human control, the garden lovers who live in the colder parts of eastern North America must bow to the inevitable. Tall-growing broadleaved Evergreens belong to the warm, temperate, 


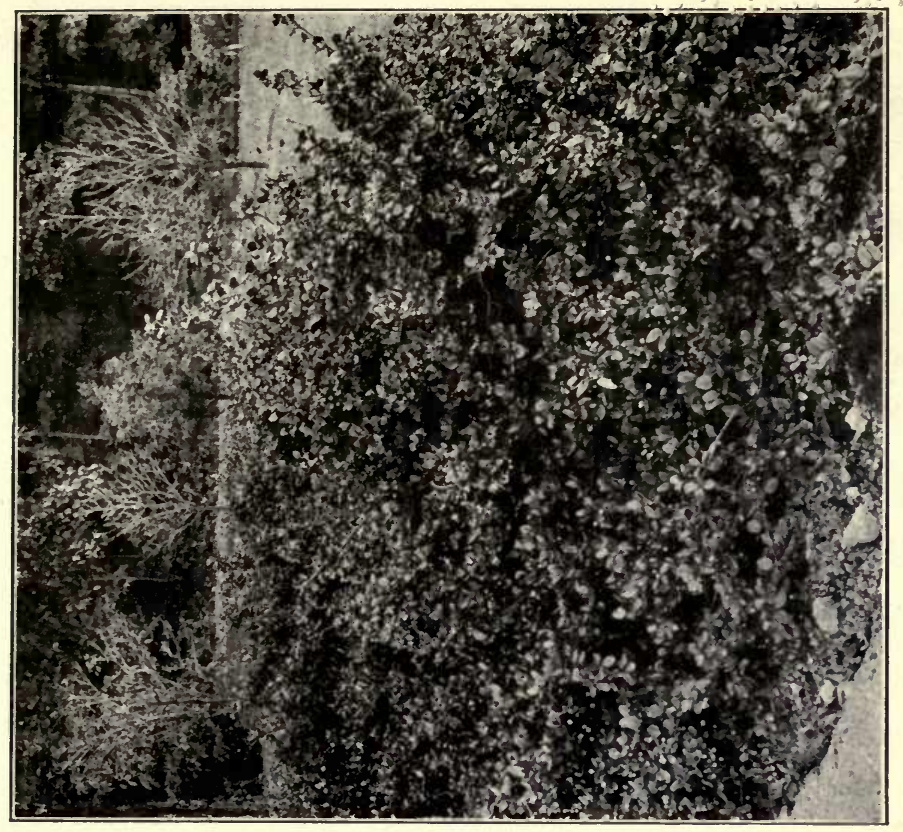

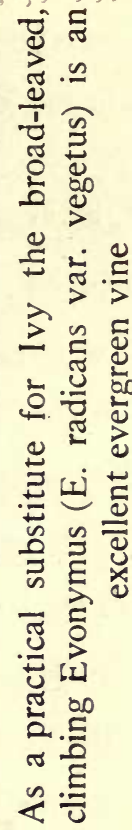

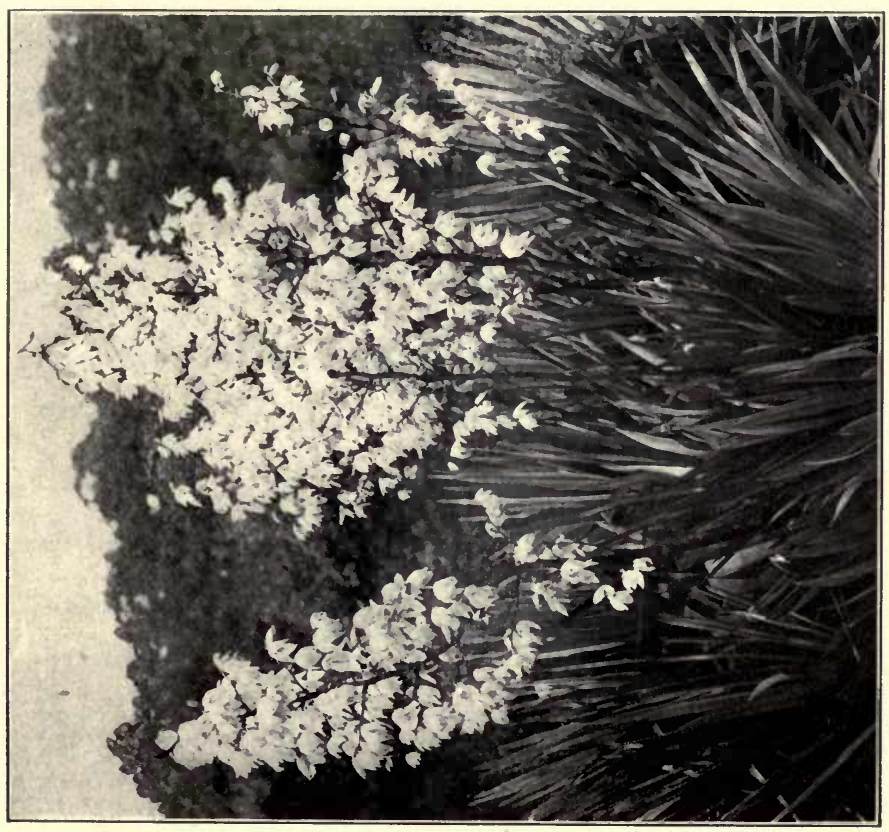

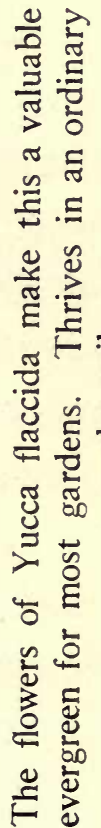


04
0 
and torrid parts of the earth and, with few exceptions, are not found in the cold, temperate, and arctic regions.

In a subsequent chapter the Rhododendrons, the noblest group of hardy broad-leaved flowering Evergreens, will be dealt with in detail, and here we may review carefully the remaining field in order to find out just what is our position in the matter of hardy broad-leaved evergreen plants. The regions of the world where possible hardy types of these subjects grow have been pretty well ransacked and the chances of New England gardens securing any notable additions are remote. China which has so bountifully supplied us with favorite flowers during the past hundred years and more, has contributed very little to our list of hardy broad-leaved Evergreens. North Japan has been fairly liberal and one or two have come to us from Europe, but the great majority are native of American soil If the whole of this country were under consideration, it would be found that more such Evergreens can be grown out of doors here than in the whole of Europe. Indeed, this is true if the Pacific Slope alone be considered, but such favored regions are outside of this purview.

In New England and southward to Washington, D. C., the case is very different and it is only after 
years of trial that gardeners learn just what plants can withstand the hot, dry summers and cold, changeable winters characteristic of these parts of eastern North America. The Arnold Arboretum is the only place in this country where data on the comparative hardiness of woody plants, covering a long period of years, is to be found. For this reason, this chapter is based on the experiences of that institution. Here and there in gardens, even in the neighborhood of Boston, Mass., a plant thrives which is not hardy in the Arnold Arboretum. Nevertheless, this Arboretum is the safest guide for all desirous of growing hardy woody plants in the colder parts of the United States of America. Very probably some reader has in his (or her) garden some broad-leaved Evergreen not mentioned here and this should be a source of joy, for the list in its extreme limits is all too scant.

We who garden in the cooler parts of eastern North America may envy those of warmer climes their variety of broad-leaved Evergreens, yet in the native Mountain Laurel (Kalmia latifolia) we possess one plant that has no superior. The foliage is good at all seasons and in mid-June the broad, dome-like clusters of bowl-shaped flowers, either pure white, or silvery to deepest pink, make a wondrous picture. Truly the Mountain Laurel is in early summer the 
glory of woodland and hill slope, and is the most beautiful of evergreen shrubs native of eastern North America. Many Asiatic Rhododendrons have larger leaves and larger and more brilliantly colored flowers, but of all the broad-leaved evergreen plants which can be grown successfully in this climate, Kalmia latifolia is the handsomest and most satisfactory. There is a variety $(a l b a)$ with pure white flowers and another (rubra) with deep pink, nearly red flowers and rather dark leaves. Between these extremes there are forms with flowers of all shades of pink and there is one (fuscata) with flowers conspicuously marked by a chocolate band. Another variety (polypetala) has the flowers segmented into narrow lobes, but this plant is not very ornamental. The variety obtusata, which rarely flowers, has broad, handsome, Rhododendronlike leaves. Lastly, there is a dwarf variety (myrtifolia) with small leaves and small clusters of minute flowers. All these varieties are sports from the wild type and have all been found on wild plants. By hybridization and selection it is highly probable that new and improved forms could be evolved. In the matter of soil and situation, the Mountain Laurel is not exacting, but it is fond of leaf mould and an autumnal mulch of leaves is beneficial. Like other members of the great Heather family, it detests lime- 
stone. This Kalmia is essentially a social plant and when massed together is most effective.

The two other Kalmias ( $K$. angustifolia and $K$. glauca) hardy in this climate are much less ornamental but are likewise evergreen. The former, familiarly known as the Sheep Laurel, is common in swampy places from Maine to Georgia and westward to Wisconsin. It is a branching shrub growing from a foot to a yard tall, and has dull olive-green leaves and clusters of crimson-pink flowers. It is popularly believed to be poisonous to sheep. The other species, known as the Pale Laurel has much the same distribution. It is a twiggy and smaller plant with flattened stems, narrow leaves with recurved edges and white on the under side and has terminal clusters of pale lilac to crimson-pink flowers. It is essentially a moisture-loving plant. Closely related to the Pale Laurel and very similar in habit, foliage, and general appearance is Andromeda polifolia. This is a low shrub from one to two feet tall, with slender stems and small clusters of pinkish urn-shaped flowers and is distributed through the cold, temperate, and subarctic regions of the Northern Hemisphere.

Another very hardy member of the Heath family is Pieris floribunda (better known as Andromeda floribunda), which opens its small, white, Heather-like 
flowers at the first burst of spring. This plant is native of the higher slopes of the southern Appalachian Mountains and is a low, broad, round-topped bush with dark green shining leaves and short, erect clusters of flowers which are fully grown in the autumn and the flower buds are white and conspicuous through the winter. Its Japanese relative ( $P$. japonica) grows taller and has larger flowers but, unfortunately, is much less hardy.

For planting in the shade of trees and more especially by the s de of woodland streams Leucothoe Catesbaei, with yard-long, arching stems, glossy green, broad, pointed leaves, and axillary racemes of small, pure white flowers, is a charming plant. It is native of the mountains of Virginia and Georgia, but is very hardy. By the side of a babbling brook in the Hemlock grove of the Arnold Arboretum it is perfectly happy and a joy to behold at all seasons of the year.

The American Holly (Ilex opaca), with its dull green leaves, is much inferior to the English Holly (I. Aquifolium), which has lustrous foliage, but it has the merit of being fairly hardy in northern Massachusetts, whereas its European relative is not. The American Holly is a large bush or small tree and has red fruit. It delights in a cool soil and a position 
sheltered from cutting winds and the morning sun in winter.

A broad-leaved Evergreen which should be planted in every garden is the Inkberry (Ilex glabra), one of the most attractive of native shrubs. It is densely branched and compact in habit and grows from five to eight feet high and as much in diameter, and has dark, glossy green, smooth, rounded leaves and black fruit on inch-long stalks. It forms a neat and shapely specimen in the open, is excellent for massing, and is a good hedge plant. The leaves do not burn and the plant grows well in ordinary garden soil and is beautiful at all seasons, be it midwinter or midsummer. One would reasonably suppose that so useful a shrub would be grown in quantity by the nurserymen of eastern North America, but, alas! this class from earliest generations has derived its inspiration entirely from Europe and apparently despises American plants as too common for attention.

The Japanese Ilex crenata is another valuable evergreen Holly and being an exotic is fairly easy to obtain from nurserymen. It makes a stiff bush with its short, dense branches and is handsome as a specimen and is well adapted for making hedges. The leaves are small, blackish green and the fruit is black and is freely produced. There are two or three 
forms of this Holly and if plants are raised from seed much variation in size of leaf is shown. Those with the smallest leaves are hardiest and seldom burn in winter, whereas the form known as major has not proved hardy in the Arnold Arboretum. This shrub, or small tree, is widely spread in Japan and is also much grown in Japanese gardens where it is usually clipped and trained into the grotesque.

The Common Box of Europe (Buxus sempervirens) is scarcely hardy in New England and as a rule browns badly in March and looks unsightly in the spring. There are many forms of this Box, and the hardiest is myrtifolia, with dull green leaves which are longer than they are broad. As a low edging around formal beds the Common Box winters fairly well when the snowfall is normal or in excess of normal, but if exposed to full sun in March the leaves scald. A much superior plant for northern gardens is the Japanese Box (B. microphylla) and its taller growing variety japonica, both being perfectly hardy in the Arnold Arboretum. The type is dwarf in habit and has narrow, wedge-shaped leaves and is very useful for edging purposes and for rockeries. The variety has rounded leaves, yellowish green in color and makes a compact bush in size comparable with its European relative. Both flower in early spring 
and are freely visited by bees. The Japanese Box, which is distinguished from the Common Box by the relatively long stalk to the rudimentary ovary of the male flowers, is far from being well known. It is rare in nurseries where forms of the less hardy $B$. sempervirens erroneously and unintentionally pass muster for it.

The lovely Oregon Grape (Mahonia Aquifolium), with its lustrous, metallic green leaves which in late fall assume rich shades of bronzy green and blackish crimson is, unfortunately, not properly hardy here. In winters, when the snowfall is heavy and lies on the ground until spring, this shrub winters fairly well; but usually the leaves burn badly and though the stems are not often killed the plants are very unsightly until new leaves develop. Much hardier and entirely satisfactory is its relative $M$. repens, with similar terminal clusters of yellow flowers and bloomy black fruits but gray-green leaves. This species grows about a foot high and has a creeping rootstock from which shoots arise and form a broad, low thicket. Very beautiful and quite hardy is the new Chinese Berberis verruculosa, with prostrate and arching stems, small, prickly Holly-like leaves, dark shining green above and white below. It grows from one to two feet high, is very densely 
branched and has yellow flowers in the axils of the leaves and these are followed by bloomy black fruit.

Very handsome in flower and striking at all seasons are the Yuccas with their spear-like evergreen leaves. Three species ( $Y$. flaccida, Y. filamentosa and $Y$. glauca) are hardy in the neighborhood of Boston, Mass., and thrive in ordinary garden soil. Their pure white, nodding, top-shaped flowers are borne in profusion on erect, branching stems from four to six feet tall.

The Garland Flower (Daphne Cneorum) is a wellknown evergreen with gray-green and terminal heads of fragrant pink blossoms. Many find it difficult to establish for it resents transplanting and for this reason pot-grown plants should be obtained in preference to those grown in open ground. For planting beneath trees there is nothing better than Pachysandra terminalis, a native of Japan and China. It grows about ten inches high and, spreading from a creeping rootstock, forms a dense ground cover in situations where but few plants will grow. The leaves are light green, and the inconspicuous flowers are followed by whitish fruits.

Another favorite broad-leaved Evergreen is the Lesser Periwinkle (Vinca minor), native of Europe and western Asia. This plant trails over the ground 
and forms a broad mass of glossy dark green. It thrives equally well in the open and in partial shade. There are forms with white and purple flowers but none is better than the type with its clear blue flowers.

A very pleasing little evergreen is Pachystima Canbyi, native of the mountains of North Carolina and Virginia, which forms neat little clumps six inches or more high. The foliage is dense, small, and rather shining pale green. The western $P$. Myrsinites is a taller plant with much larger leaves but the habit is less good and it often suffers in winter. These plants have inconspicuous flowers and are related to the Spindle-trees (Evonymus).

The Cowberry (Vaccinium Vitis-idaea) is a northern, circumpolar plant which grows a few inches high and forms dense, broad mats. The leaves are shining green, the flowers white or pinkish and the fruit dark red. At any season of the year this little plant is pleasing. A closely related evergreen is the Box Huckleberry (Gaylussacia brachycera), one of the rarest of American plants. It is a spreading plant growing from six to ten inches high and has shining green Box-like leaves.

The Mayflower or Trailing Arbutus (Epigaea repens) common on the borders of rocky woods and 
hillsides of New England and southward, is a lovely plant but alas! not very amenable under cultivation. Its sweet-scented white to delicate pink flowers open beside the remnants of snowdrifts in early spring. It is regrettable that this plant, a favorite with everybody, is so coy and hard to please in gardens. An allied plant, the Wintergreen or Checkerberry (Gaultheria procumbens), however, grows readily in any garden soil. This common shrub, so abundant in woodlands and wild places generally from Maine southward and west to Michigan, grows from three to six inches high and has lustrous dark green ovate leaves clustered on the top of a ruddy stem and tiny urn-shaped white flowers which are followed by pure red, hanging, aromatic fruits.

The Crowberry (Empetrum nigrum), abundant in cold, temperate, and sub-arctic regions throughout the Northern Hemisphere, has insignificant leaves, yet it forms neat mats of dark green in the vicinity of eternal ice and snow. Its relative, Corema Conradii, is a more conspicuous plant with broader leaves and forms compact clusters about six inches high.

As a ground cover in the open there is nothing better than the Bearberry (Arctostaphylos uva-ursi), with its long trailing shoots and gray-green leaves forming a dense carpet. The flowers are white or pinkish, 
urn-shaped, and borne several together at the end of the lateral shoots; the fruit is globose and winered. Like many other members of the Heath family, the Bearberry is not only native of this country, but is spread over the colder regions of the Northern Hemisphere. This prostrate evergreen can be used to good effect in many ways, but I never saw it more appropriately employed than in a private cemetery on Long Island, N. Y., where, in an opening in a thin wood, it carpets a basin or bowl round which nestle flat graves in clearings of the native vegetation.

- The Creeping Snowberry (Chiogenes serpyllifolia), with thread-like stems and white fruits, is pretty on rocks and tree stumps in shady places. So, too, is the well-known Partridgeberry (Mitchella repens), with a similar habit and scarlet fruits, though belonging to a widely different family.

Twice previously in these pages reference has been made to the Heather (Calluna vulgaris) and certain Heaths (Erica spp.), but I may again emphasize the fact that these charming plants are perfectly hardy provided they be grown in the open where they may enjoy the full sun and wind.

For climbing plants with evergreen foliage we are badly off. The Ivy (Hedera Helix), so celebrated in 
poetry and folklore, is not hardy, although here and there rambling over an old tomb in a shady part of some cemetery, a plant may be found more or less indifferent to the winter's severity. No other plant can exactly take the place of the Ivy, but we are really fortunate in having so good a substitute as the Japanese Evonymus radicans and its variety vegetus. These are invaluable plants with good foliage, are quite hardy, and admirably adapted for covering walls and the north and west sides of buildings. On boulders or even in the open border they form a fine tangled mass of green. They are root climbers and have small white flowers in clusters and attractive white fruits which open and display the seeds with their orange-scarlet covering. The juvenile stage of the variety vegetus is sold under the name of Evonymus radicans, var. minimus and also as Evonymus kewensis. It has prostrate stems and prettily marbled rounded foliage and is a charming cover and rock plant. In China grows $E$. radicans, var. acutus and the baby stage of this plant has ovate, marbled leaves and from the manner of its growth in the Arnold Arboretum promises to be a very useful addition to the best of evergreen climbers.

The only hardy and really evergreen twining vine we have is Lonicera Henryi, a recent addition from 
China. Over walls and rocks this plant makes a delightful tangle and, whilst the flowers are not showy and the fruit is dull black, the leaves are of good size and dark green throughout the winter.

There are a few other broad-leaved Evergreens whose hardiness in New England is not yet fully established and a number of the low-growing plants mentioned here are better suited for the rockery than for the open border. 
文

a 


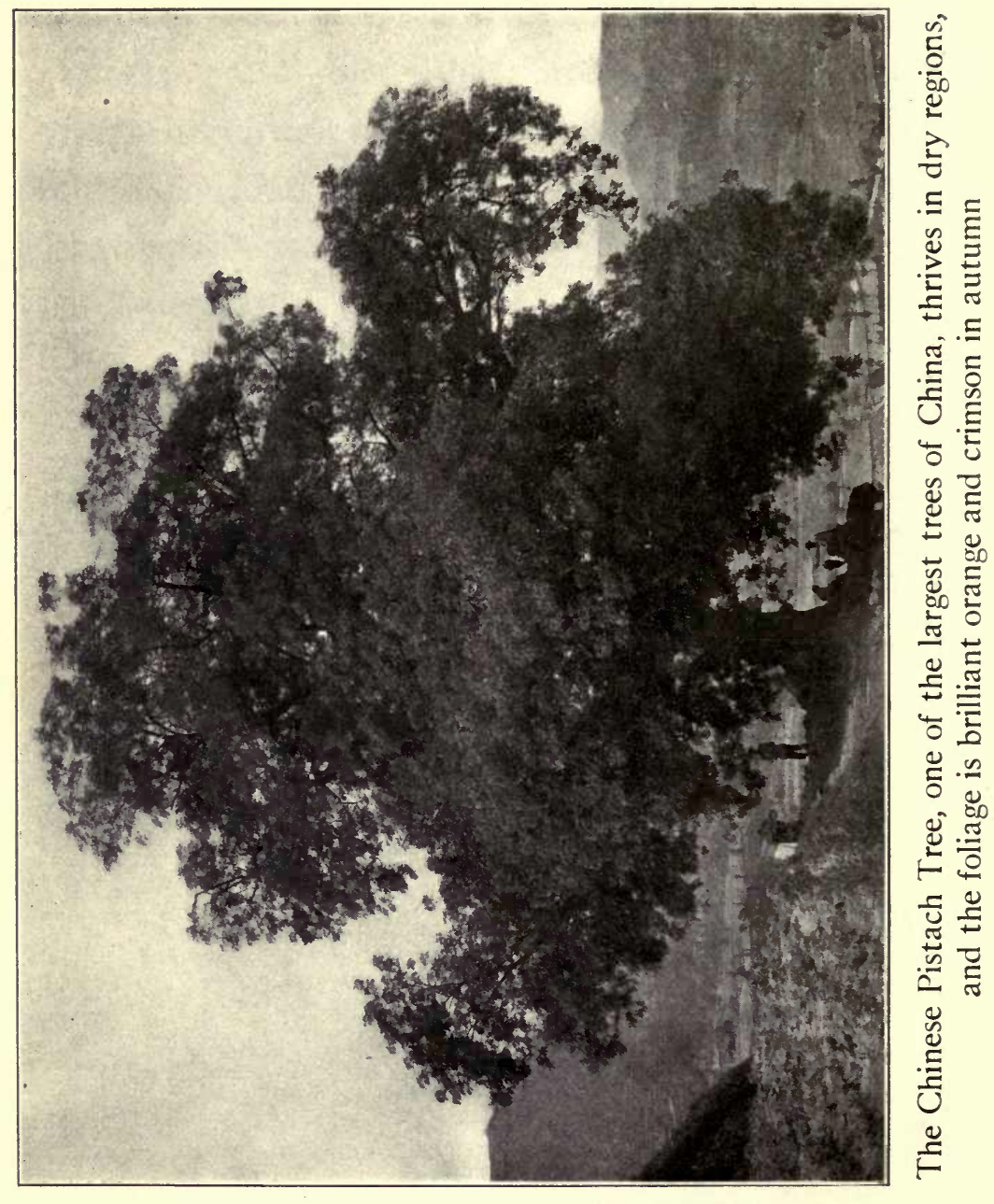




\section{CHAPTER IX}

NEW CHINESE TREES AND SHRUBS FOR THE PACIFIC SLOPE AND OTHER FAVORED REGIONS

SOME SPLENDID EXAMPLES AMONG THE GREAT WEALTH OF MATERIAL THAT HAS RECENTLY BEEN BROUGHT TO NOTICE

7 HE region of the Pacific Slope with its mild and genial yet diversified climate offers enormous

Lorticultural possibilities, and in the state of California alone it is possible to cultivate out of doors a greater variety of plants than in any other state of the Union. In the North the climate is similar to that of the west coast of Scotland; in the South it is like that of Palestine; from San Francisco to Santa Barbara it resembles that of the Riveira and Algiers.

Among the great attractions at the Panama-Pacific International Exposition in San Francisco and the Panama-California Exposition in San Diego were the remarkable floral displays Visitors from the East and Middle West fully conversant with the horticultural material grown in their own sections were amazed and bewildered at the variety and the totally 
different classes of plants which flourish in the open in California. Plants which in the East and Middle West are grown under glass in pots for table and hall decoration, in California grow out of doors into large bushes and stately trees; and the same is of course also true to a certain degree of the region abutting on the Gulf of Mexico.

In New England only plants from the cold temperate regions of the Northern Hemisphere flourish in the open ground but on the Pacific Slope and in the real South the plants of the cool and warm temperate regions of both Hemispheres thrive out of doors and garden lovers there may enjoy the beauties of a host of plants eastern gardens know not of.

There are drawbacks of course and gardeners in these warmer climes have difficulties peculiarly their own. In parts of the South and West there is a meagre water supply but this can be and is overcome by irrigation. In many places the soil is more or less alkaline and such a soil most plants abominate. When only slightly or moderately alkaline the soil may be neutralized by growing on it crops of beets or even by washing. In only slightly alkaline soils most trees and shrubs will grow if vigorous specimens a yard or more tall be planted and given careful attention for a few months. With young seedlings and small plants raised from 
cuttings it is otherwise and until these become of fair size and full of vigor it is necessary that they be grown in a neutral soil.

Except in extreme cases the difficulties are not insuperable, and over the greater portion of the Pacific Slope there is little to hinder successful gardening. Parts of California have become one of the flower-seed producing areas of the world and it is highly probable that others will become famous for bulbs of the sorts now obtained in such quantities annually from Holland. The Roses of Oregon are renowned and the highly colored apples from the northern areas of the Pacific Slope are famed the world over.

Many new plants have been raised on the Pacific Slope by various people, including a new race of Roses by crossing the Chinese Rosa odorata, var. gigantea and the Himalayan R. Brunonii. Mr. John McLaren, the Nestor of Californian gardening, has shown what an infinite variety of beautiful plants can be successfully grown in the open ground in and around San Francisco, and the wonderful collection in the Golden Gate Park is a monument to the skill, foresight, and perseverance of this remarkable man.

Now, recent exploration work in central and western China has added some hundreds of new plants to western gardens and of these rather less than one half 
have proved hardy in the states of Massachusetts and New York. In Great Britain virtually all have become acclimatized and there is good reason for believing that a majority will flourish on the Pacific Slope and on the Gulf. Some have already proved their adaptability, as, for example Cotoneaster pannosa and Jasminum primulinum.

I do not propose to mention here the new introductions from China which thrive in the Arnold Arboretum, Boston, Mass. These are dealt with elsewhere in this work. My object is to tell of certain trees and shrubs of an ornamental character suitable for the more favored climate but which cannot withstand the rigors of New England winters. Many of these are evergreen in character and all are of proven value in parts of Great Britain and France. I will commence with the Rose so universal a favorite and one in which we are so deeply indebted to China which gave us the parents of our Tea, China, and Rambler Roses.

Three species of Musk Rose (Rosa Rubus, R. Gentiliana, and $R$. Helenae) are abundant in the temperate parts of eastern and central China and two others (R. filipes and $R$. longicuspis) are common in the western part of that land. The first four are quite new and the fifth though long ago recorded from 
India has remained an obscure plant down to the present time. All are strong-growing species making tangled bushes fifteen feet tall and twenty feet and more through and all have fragrant musk-scented flowers. In $R$. filipes the inflorescence is pyramidal and the flowers are rather small with slender stalks and are borne a hundred or more together in one truss. The other species have larger flowers produced in broad, flattened, or rounded masses. In $R$. Rubus the leaves are five-fol:olate and hairy on the underside; in $R$. Gentiliana they are five-foliolate and glaucous below; in $R$. Helenae seven- to nine-foliolate and slightly hairy on the underside; in $R$. longicuspis they are seven- to nine-foliolate, intense green and quite smooth. There are of course other technical and obvious differences which need not be related here, but all are extremely floriferous, last in bloom for more than a month, and retain their foliage very late in the season. No species of Rose is more beautiful in flower and foliage than these and one and all with their cascades of pure white fragrant flowers are delightful garden shrubs. Further, they offer possibilities in the development of new races of Roses which the hybridist can best appreciate. With rose-pink flowers there is the pretty $R$. Willmottiae which is an erect-growing shrub with arching 
branches, small gray-green 'eaves and flowers in pairs or singly, and the allied $R$. multibracteala with larger and greener leaves and clusters of numerous rose-colored flowers. There are other species, too, but this half dozen must suffice.

A genus of ornamental shrubs which recent work in China has vastly augmented is Cotoneaster. Two dozen of these new species have deciduous leaves and thrive amazingly in the Arnold Arboretum, but about half a dozen have evergreen leaves, and are not hardy there. One of these, C. pannosa, flourishes in and around San Francisco and Mr. McLaren told me that he considered it one of the most valuable plants of recent introduction. Closely related to that species is C. Harroviana which is a superior plant with rather larger and thicker shining green leaves, broader masses of flowers and wide-spreading branches with red-purple stems. The Willow-leaved Cotoneaster (C. salicifolia) is an erect shrub growing ten to twelve feet tall with arching branches, pendent whip-like branchlets, narrow shining green leaves clothed with a felt of white hairs on the underside and flat corymbs of flowers. Its variety rugosa has rather shorter and broader leaves which are undulate on the upper surface; the variety floccosa has more narrow leaves and brighter red fruits than the 
type and the habit is more spreading. The allied

C. Henryana is a strong-growing shrub, ten to fifteen feet tall with spreading slender branches pendent at the tips and relatively large leaves, rather thin in texture, bright green above and slightly downy, and broad masses of white flowers which are followed by small fruits. The above all have showy flowers, brilliant red fruits, and good foliage. In C. Franchetii and $C$. amoena the flowers are insignificant but the scarlet fruits are large and conspicuous and produced in great abundance. These are much-branched shrubs growing from six to twelve feet high with twiggy slender, gracefully arching and spreading branches, and small leaves, dark green above and gray below. Though normally deciduous the leaves persist and retain their freshness through the winter in mild climates.

As a ground cover either on the flat or for steep slopes C. Dammeri (better known as C. humifusa) is a most valuable acquisition. It is perfectly prostrate and roots are freely emitted from the branches; the evergreen leaves are rounded and small and intense shining green, and the flowers, which are relatively large and pure white, are produced singly or severally together and are followed by bright scarlet fruits. 
The Japanese Photinia glabra and the Chinese $P$. serrulata are much-esteemed evergreen shrubs in California and the former is a valuable hedge plant. The new $P$. Davidsoniae is superior to either. This is a shapely evergreen tree growing from forty to fifty feet tall with dark glossy green leaves which are reddish when young, and white flowers borne in broad flattened heads and followed by masses of scarlet fruits. It is a great favorite among the Chinese and in central China is commonly planted round shrines and tombs.

Closely allied to Cotoneaster is Pyracantha of which the European $P$. coccinea and its var. Lalandii are well-known and much-appreciated shrubs on the Pacific Slope. The Chinese $P$. crenulata and $P$. angustifolia are magnificent when in fruit. The firstnamed resembles the European species in habit but has differently shaped leaves and the fruits vary in color from red to orange-scarlet. The other is upright in habit with rigid, horizontally disposed branches, and narrow, oblong, dark green leaves. The fruit is scarlet but in habit and general appearance this new plant is very distinct.

Not far removed in relationship from the above is Stranvaesia with green persistent leaves, which in winter become beautifully tinted, and broad flat 
heads of pure white Hawthorn-like flowers followed by masses of scarlet to orange-scarlet fruits. There are two kinds: $S$. Davidiana with rather large oblong leaves and its variety undulata with much smaller and narrower leaves. Both are much-branched shrubs growing from five to fifteen feet tall and as much in diameter. Another pleasing shrub and one capable of withstanding much drought is Osteomeles Schwerinae which has very small, pinnately divided, dark green persistent leaves, showy white flowers, and black fruits.

Among the new Viburnums from China are a number of very distinct and ornamental evergreen species. One of the best is V. Henryi which is a large much-branched shrub from ten to fifteen feet high with ascending and spreading branches, thick, glossy green oblong leaves, erect pyramidate masses of pure white flowers and beautiful fruits which as they ripen change to coral-red, scarlet, and finally to jet black. This new-comer is one of the most strikingly handsome members of a distinguished group. Very distinct too is V. Davidii which has dark green, leathery leaves with prominent veins. This is a low-growing, branching shrub seldom exceeding two feet in height with broad flat heads of pure white flowers which are succeeded by indigo-blue fruits. It is very suitable for 
rockeries and makes a good ground cover. Other species with blue fruits are $V$. propinquum and $V$. Harryanum. The former is a loosely branched shrub growing from five to ten feet high and has shining green lance-shaped leaves two to four inches long; the other is very compact in habit with twiggy shoots and small deep green rounded leaves and is totally unlike any other Viburnum and closely resembles Box (Buxus) in general appearance. Both have inconspicuous greenish white flowers. Another fine Evergreen is $V$. coriaceum which is a large tree-like bush growing from fifteen to twenty-five feet tall with ascending and spreading branches clothed with large dull green leaves and bearing in season trusses of creamy-white flowers with conspicuous blue stamens and bloomy black fruits. Very different is V. utile with flattened round heads of fragrant flowers, pink in the bud and pure white when fully expanded, and jet black fruits. This is a much-branched shrub growing from six to twelve feet tall, with twiggy branches, small, thick leaves, lustrous dark green above and gray on the underside. This species grows naturally in rocky places and withstands drought exceedingly well. A remarkable Viburnum and totally unlike any other is V. rhytidophyllum with long deep green, lance-shaped, strongly wrinkled leaves which on the underside are covered with 
a dense white felt. It is a shrub from five to ten feet tall, compact in habit and has broad flat heads of dirty white rather foetid flowers succeeded by handsome fruits which as they ripen change to pink and crimson and are finally jet black. Somewhat similar in aspect to the preceding is $V$. buddleifolium but its leaves are smaller and thinner and are scarcely wrinkled and its flowers more showy.

One of the most charming of recently introduced evergreen shrubs is Lonicera nitida which is lovely as a lawn shrub, of unique value for making low hedges, and may be trimmed and used in the manner of Box for edging garden paths and flower beds. It grows from three to six feet tall and has innumerable rigid, twiggy, ascending and spreading branches densely furnished with small glossy green leaves; the flowers are yellowish-white, small but very fragrant, and the fruits are bluish purple. This shrub roots readily from cuttings and grows freely and rapidly in any ordinary garden soil. Akin to the preceding is $L$. pileata which has similar flowers and fruits but larger leaves, not shining, and low-spreading and prostrate in habit.

Of evergreen Privets two new-comers (Ligustrum Henryi and L. Delavayanum (better known as L. Prattii) are worthy of recognition. The former has rather short and broad shining green leaves and the other 
more narrow and oblong leaves which are also lustrous. Both are branching shrubs growing from five to eight feet high and make fine specimens, and L.Delavayanum, on account of its free habit, neat growth and dense foliation, is a most valuable hedge plant.

Camellias in variety with their shining evergreen leaves and handsome flowers are general favorites and in the new C. cuspidata (correctly, Thea cuspidata), we have the hardiest species of the genus. It is a shrub from four to eight feet tall, with small leaves, single white flowers of medium size and it flowers very freely when the plants are quite small.

China is very rich in species of Holly and a number of valuable and distinct kinds have been added to our gardens. The best of its class is Ilex Pernyi which is a shrub, from six to eighteen feet tall, narrowly pyramidal in outline with rigid branches and small, very spinous dark green leaves and red fruits. Either for specimens or for hedges this Holly is invaluable. Closely allied to the above is $I$. Veitchii which is similar in habit but has very much larger leaves. Quite unlike one's conception of a Holly are $I$. Fargesii and $I$. Franchetiana with their long, narrow, Willow-like entire or slightly toothed leaves. Both are largegrowing, sparsely branched shrubs with white fragrant flowers and relatively large scarlet fruits. Very 
distinct too is $I$. yunnanensis with its compact columnar habit, small rounded spineless leaves and pink fragrant flowers which are followed by small red fruits. Another good Holly is $I$. corallina with oblong, lance-shaped leaves from two to three inches long, undulate along the margins and sessile clusters of small vivid scarlet fruits. This is a shrub growing from six to twelve feet high with slender spreading and more or less pendent branches.

Very like the common European Holly (Ilex Aquifolium) in foliage is Itea ilicifolia which belongs to a totally different family. This is a sun-loving, drought-resisting, much-branched shrub growing from six to twelve feet tall with small white flowers borne in slender cylindrical pendent tails each from twelve to eighteen inches long. Both in flower and foliage this evergreen shrub is singularly attractive.

One of the most valuable garden shrubs cultivated on the Pacific Slope is Berberis Darwinii, native of Chile, South America. From China, which is the headquarters of the Berberis family, there has been recently introduced a large number of new species and among them several of quite exceptional merit. In the front rank of these is $B$. Gagnepainii with masses of clear yellow flowers followed by bloomy black fruits. This is a compact shrub from five to eight feet tall, 
columnar in outline with narrow-pointed dull green persistent leaves. Other valuable species are $B$. atrocarpa, B. Julianae and B. Sargentiana, which differ one from another in size and shape of leaves and fruits but agree in being much-branched upright growing shrubs, from five to eight feet tall, with thick dark evergreen leaves, yellow flowers and black fruits. The sparingly branched $B$. Veitchii (known in gardens as $B$. acuminata) is very distinct and so is $B$. triacanthophora which is a twiggy shrub, from three to five feet tall and as much broad, with yellow flowers stained with red, and black fruits. For rockeries and rocky places the semiprostrate $B$. candidula and $B$. verruculosa with small evergreen Holly-like leaves, lustrous above and white beneath, are most delightful plants. Another low-growing species is $B$. Wilsonae with dense twiggy branches, gray-green semipersistent leaves which become beautifully tinted in the late fall, and masses of yellow flowers succeeded by brilliant salmon-red globose berries.

As low-growing evergreen shrubs suitable for dry soils and for planting under trees, Sarcococca humile and $S$. ruscifolia may be confidently recommended as useful additions to the limited number of plants that will thrive under such conditions.

A strikingly handsome evergreen shrub of medium 
height is Osmanthus armatus with thick Holly-like leaves from four to six inches long and from one to one and a half inches broad and coarsely toothed. The flowers are creamy-white and very fragrant and are produced in the autumn. The spring-b'ooming $O$. Delavayi, with small leaves and pure white fragrant flowers, is also worthy of the widest recognition. Another useful evergreen shrub or small tree is Sycopsis sinensis, a relative of the American Witch Hazel, with inconspicuous flowers, twiggy branches, and neat foliage.

My Jasminum primulinum with its arching shoots, dark green leaves, and large, clear yellow flowers produced from the leaf-axils, needs no introduction to the Pacific Slope, but the red-flowered J. Beesianum deserves to be better known. This is a low-spreading and even prostrate shrub with simple dull green leaves, and is very suitable for planting on banks. It is fond of sun, can withstand drought, and the flowers though described as red vary to pink and even to nearly white.

Popularly known as Summer Lilac Buddleia Davidii and its varieties have won widespread recognition since I introduced them some fifteen years ago and they have been frequently mentioned in the Garden Magazine. For the Pacific Slope two 
other species which produce their flowers in January and February are strongly recommended. One of these ( $B$. asiatica) has pure white, deliciously scented flowers arranged on long, slender cylindrical tails, gray Willow-like leaves, and slender arching and spreading branches. The other ( $B$. officinalis) is a more sturdy shrub with broader leaves, stouter branches, and broader branching heads of rose-pink flowers each with an orange eye. A hybrid between these two species has been raised and named $B$. Farquharii. This plant has pale pink flowers and is perfectly intermediate between the parents and combines the good qualities of both. These "Winter Lilacs," as they may be termed, are very free growing and free flowering shrubs and to obtain the best results they should be severely pruned each year after flowering.

The Brambles (Rubus) are not usually regarded as ornamental garden plants but many of the Chinese species have strong claims to be so considered. Among semi-evergreen species with attractive foliage and pleasing habit I may mention Rubus chroösepalus with leaves like those of Tilia petiolaris; $R$. bambusarum with three-partite leaves, dark green above and dun-colored below; the closely allied $R$. Henryi with lobed leaves; $R$. flagelliflorus with entire leaves 
marbled with metallic green and brownish-purple above; $R$. Swinhoei with narrow oblong pointed leaves, gray on the underside; and $R$. ichangensis with vivid green nearly heart-shaped, pointed leaves and large elongated clusters of bright red fruits. All these Brambles have slender whip-like shoots and when trained to poles or to a pergola are very attractive.

New deciduous-leaved flowering shrubs are so very numerous that I hesitate to embark on the subject and I shall content myself with the mention of three groups. The Deutzias are much appreciated spring-flowering shrubs and in our gardens we enjoy several old species and the wonderful race of beautiful hybrids evolved by the late Monsieur Victor Lemoine of glorious memory. In addition to these China has given us quite recently a number of very distinct and lovely species such as the rosy-lilac flowered $D$. longifolia and its more deeply colored variety Veitchii; D. Wilsonii with glistening white flowers larger than those of any of its allies; $D$. discolor with large masses of white flowers; $D$. Schneideriana and its variety laxiflora with pyramidate trusses of white flowers, and the curious $D$. mollis with soft hairy leaves and flattened heads of small white flowers. These species are valuable for em- 
bellishing outdoor gardens as specimens or for forcing purposes for Christmas and Easter.

Closely allied to the Witch Hazel (Hamamelis) is Corylopsis, of which the Japanese C. spicata and C. pauciflora are well known. From China the genus has recently been considerably augmented and such species as C. sinensis, C. Veitchiana, C. Willmottiana, and C. platypetala are decided acquisitions. Like the Japanese species they are spring-flowering shrubs and have pendent short racemes of yellow fragrant flowers which are produced in great profusion before the leaves unfold. The leaves are gray-green, and either in flower or foliage these shrubs are of pleasing appearance. Another new spring-flowering shrub is Stachyurus chinensis with pendulous racemes of yellow, scented flowers. This forms a bush from five to eight feet tall and has spreading branches, deep green leaves, and purplish brown shoots.

Lastly I may mention Salix Bockii and S. magnifica, two most extraordinary Willows. The former is an upright-growing, much-branched twiggy shrub with small gray-green leaves and is worth growing as an autumn flowering plant. The catkins are white and are borne in great profusion on the current season's shoots in the late summer and autumn-a character almost unique in Willows. The other is a 
magnificent foliage plant. It is a large bush, from ten to twenty feet tall, with gray-green leaves on red stalks and I have measured the leaf-blade eight inches long and five and a quarter inches wide! The leaves rather suggest those of the Yulan (Magnolia denudata), so much so in fact that when I discovered the plant I momentarily took it for a species of Magnolia.

Of new trees worthy of recommendation there are many, but I have space to mention only a dozen. The Bull Bay (Magnolia grandiflora) of the southeastern states is rightly appreciated as one of the noblest and beautiful of all flowering evergreen trees. From China, gardens have received a closely allied species (M. Delavayi) which has larger and pointed leaves, dull green above and pale below and equally large, white cup-shaped flowers. These two Magnolias are of about equal hardiness and are most worthy companions.

An ornamental flowering tree is Carrieria calycina with its bright green oblong leaves and pyramidate heads of ivory-white waxy flowers. It is a muchbranched, flat-headed tree of medium height and the flowers are borne conspicuously at the ends of the shoots.

One of the most beautiful of small trees is Staphylea holocarpa with large pendent clusters of pure 
white to pink flowers borne in profusion before the leaves unfold. The variety rosea has rose-colored flowers and the leaves are downy on the underside. Both form slender trees, from fifteen to thirty feet tall, with spreading branches, bright green leaves, and pale green twigs. The flowers are rich in honey and deliciously fragrant.

The Tree of Heaven (Ailanthus glandulosa) is a very old inhabitant of gardens but the new $A$. Vilmoriniana, although much less hardy, is a more handsome tree. When young the trunk and branches are thickly studded with short prickles. The leaves are more than a yard long and the rhachis is reddish in color and prickly, and no other tree of north temperate regions has so large leaves. It grows very rapidly and is native of the warm arid valleys of central and western China.

A tree which thrives in dry regions is Pistacia chinensis. This is one of the largest of Chinese trees and has a very thick trunk, massive, widespreading branches which form a flattened or rounded crown; the leaves are dark green pinnately divided and in the fall assume wondrous tints of orange and crimson. The flowers are inconspicuous but the bunches of small fruits, which are rich in oil, are showy and as they ripen change to scarlet and are 
finally blue. The wood is valuable and the young shoots with half-grown leaves are eaten as a vegetable by the Chinese after the manner of spinach.

The Chinese Hogplum (Spondias axillaris) is another drought-resistant tree worthy of extended cultivation. It grows from forty-five to eighty feet tall and has thick branches forming an oval or flattened crown. The leaves are pinnately divided and the oval to ellipsoid yellow fruit is edible but lacks flavor.

In eastern and central China the people consider Xylosma racemosum and its variety pubescens the most beautiful of all their evergreen trees and apply to it a name which signifies "Wintergreen." It is commonly planted over shrines and graves and in temple grounds, and has dark lustrous green leaves, inconspicuous flowers, and black pea-like fruits. The branching is dense and the crown wide-spreading, oval, rounded, or flattened and the short inner branches are spiny.

A Chinese Poplar (Populus lasiocarpa) has larger leaves than any other member of the genus. It is a moisture-loving tree, rather sparsely branched, and loosely pyramidal in outline and has bright green heart-shaped pointed leaves, from ten to twelve inches wide and more long, with the leafstalks, midrib, and principal veins of a rich red hue. In the mild parts 
of the Pacific Slope which enjoy a moist climate this new Poplar should prove a great acquisition to the list of ornamental foliage trees. A handsome new Poplar is $P$. Wilsonii with its large, rounded, and slightly pointed leaves dark green above and pale on the underside. Other valuable Poplars suitable for the cooler parts of the Pacific Slope, but quite hardy in the coldest parts of this country, are P. suaveolens, $P$. szechuanica, and $P$. Simonii, both quick-growing trees useful for street or park planting.

It would be a simple matter to increase this list fourfold and then not enumerate all the new Chinese plants worthy of recognition. But finality is not attempted. Garden lovers of the Pacific Slope who take up even half-a-dozen of the plants mentioned here and give them the same attention and treatment accorded to more familiar trees and shrubs will assuredly enjoy pleasurable satisfaction. 

$\because \because \cdots: \because \because \vdots \vdots \vdots$

$\therefore: \vdots \because: \because: \because \vdots: \vdots \vdots: \therefore \cdots$

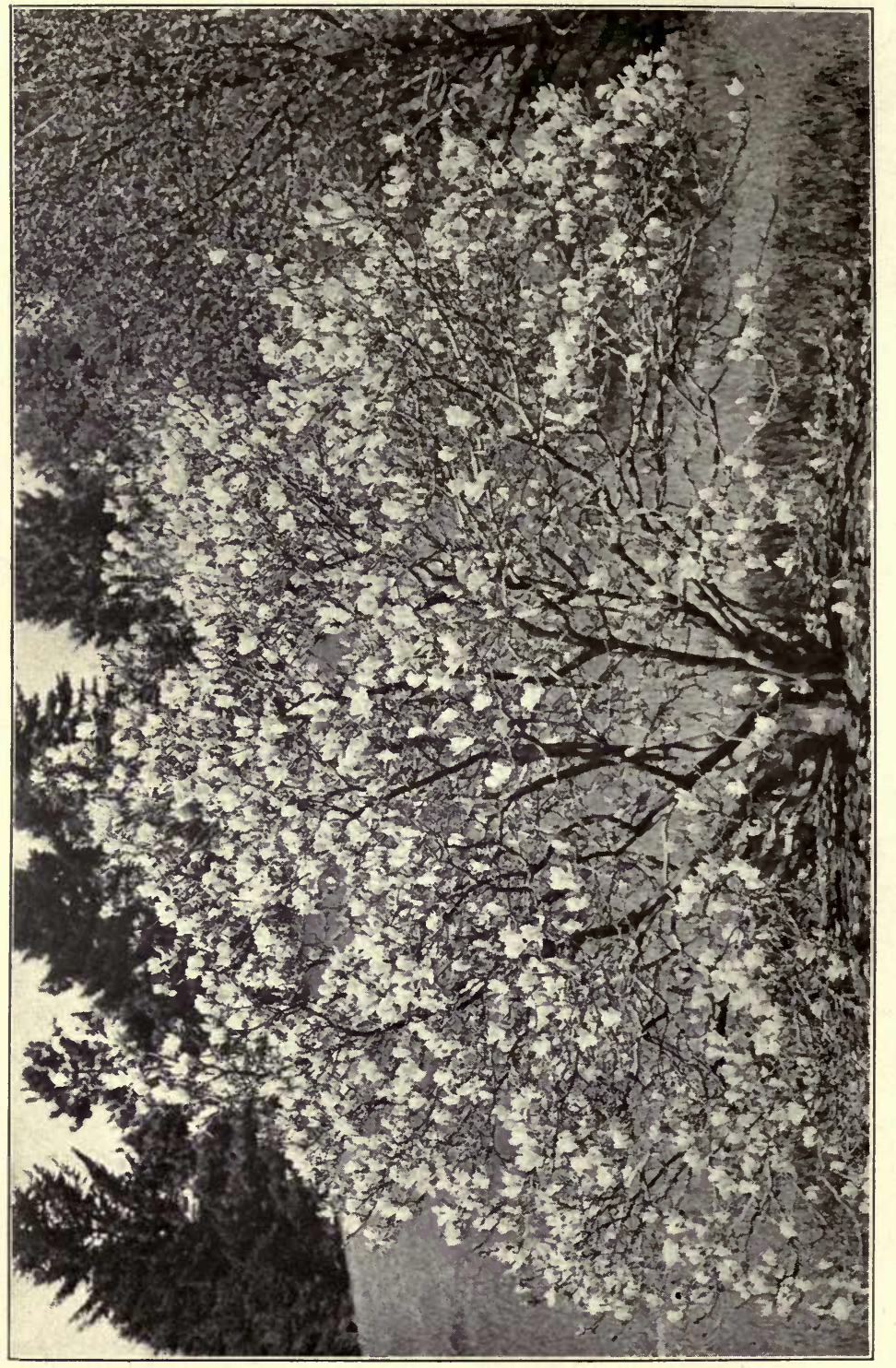

$\frac{1}{2}$

4

芯

$\triangle 2$

के

굴

든

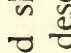

ฮ.

\&

\&

$\pm$

00

를

ते

은

00

튼

के :

능

ส

음

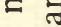

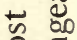

토

c

도

品

을

ह

닌

สิ

은

응

홍

$\sum$

$\underline{\Xi}$ 


\section{CHAPTER $\mathrm{X}$}

\section{EARLY SPRING-FLOWERING TREES AND SHRUBS}

ONE OF AMERICA'S GOLDEN OPPORTUNITIES

TF THERE be one season of the year wherein outdoor flowers are more keenly appreciated than

1 another it is without doubt that of spring. All of us welcome the season when Nature puts on new apparel and appears in all the freshness of vigorous youth. And rightly so, for fallen indeed is the state of those in whom the joyousness of spring finds no answering echo. Garden lovers in particular greet the springtime with open hands and gladsome hearts, for then appear in beauteous blossom a hundred and one plant treasures Who among us does not welcome that sweetly pretty harbinger of spring the Winter Aconite (Eranthis hyemalis) with its small, clear yellow flowers? And with what pleasant thrill we note the first expanding blossoms of the Snowdrop! Possessors of gardens differ widely in their tastes and affections for different classes of plants but all agree in the desire for subjects which produce flowers early in the 
spring. Of material both herbaceous and woody there is ample and in every garden there is room for improvement. The central truth which all should realize is that in gardens it is in variety not in uniformity that beauty must be sought.

In the woods and by the roadside and on the margins of swamps a number of native woody plants put forth their blossoms very early in the spring and escape the notice of the multitude who pass them by. The Silver Maple (Acer saccharinum) in New England is the first of native trees to open its flowers, which are heavily clustered on the naked twigs but are less conspicuous than those of the Red Maple (A. rubrum), which open soon afterward and are red or orange-red and sweetly fragrant.

The American Elm (Ulmus americana) is one of the most beautiful of all trees, with its massive trunk dividing a few feet from the ground into several or many stout ascending stems, which branch and form a rounded or flattened wide-spreading crown in which the lesser branches are more or less pendent. In this tree, too, the flowers are clustered on the naked twigs and consist of little more than pink anthers suspended on elongating thread-like filaments. In the Hazelnut (Corylus) and in the Alder (Alnus), the female flowers are insignificant but the male flowers are borne on 
long, cylindrical catkins which are clustered together near the ends of the twigs, and examination will show that the stamens are brightly colored. The Pussy Willows (Salix) are the most noticeable and most appreciated of plants which in early spring produce their flowers in catkins. The Poplars (Populus) also bear their blossoms in a manner similar to the Willows and in certain species the stamens are handsomely colored.

But before the earliest Silver Maple or Pussy Willow shows any signs of welcoming spring by putting forth blossoms the Witch Hazels (Hamamelis) have expanded their flowers and most of the petals have fallen. This small group of shrubs deserves to be much more widely known, for it possesses attractions that are absolutely unique among hardy plants. The native $H$. virginiana, so common in woodland and copse, is the last of shrubs to blossom in the autumn, when its yellow star-shaped flowers are hidden midst a mass of yellow-tinted foliage. As the leaves fall the flowers are seen to better advantage, and individual bushes may be found in December with a few odd flowers bravely facing the first strong blasts of winter.

The other three species open their flowers in January and February, when the twigs are bare and when snow carpets the ground and all around is dreary and 
uninviting. The best known of these is the Japanese Witch Hazel (H. japonica), so abundant in the woods of the Nikko region of Japan and elsewhere in that land. It is a large bush from twelve to fifteen feet high, with many stiff, ascending-spreading branches and twiggy shoots and smooth leaves like those of the native $H$. virginiana. The star-shaped flowers, each with five long, strap-like, canary-yellow petals, surrounded by a calyx which is wine-colored on the inside, are fragrant and thickly stud the shoots and branches. The variety arborea is distinguished by its more golden-yellow petals and more richly colored calyx and its flowers open a little in advance of those of the type.

The finest of the genus is the Chinese $H$. mollis, which is similar in habit to the Japanese kind but has larger flowers which open earlier and larger leaves which are softly hairy on the underside. This shrub is native of the mountains of central China and, although it is now some thirty-six years since it was introduced to cultivation by the late Charles Maries, it is little known and far too rarely seen in gardens. A few years ago a Witch Hazel, which forms thickets in the gravelly beds and on the margins of streams in southern Missouri, Arkansas, and Louisiana, was recognized as a new species and named $H$. vernalis. 
Some small plants were obtained and these opened their flowers for the first time under cultivation in the Arnold Arboretum on January 15, 1913, a little before those of its Asiatic relatives. The flowers are fragrant and, though smaller, are more freely produced than in any other species. The inside of the calyx is wine-colored as in the Asiatic species; the narrow petals are erect-spreading, somewhat undulate with the apex inflexed, usually yellow, often golden, and in some flowers stained with wine color. The leaves resemble those of the common American Witch Hazel but are more hairy and are often somewhat glaucescent on the under surface. Its habit is stoloniferous (i. e., it suckers freely) and in this respect it differs from all other species. The plants when they first flowered were not more than two and a half feet high; but they have grown much since, though they have not attained their maximum height, which is said to be six feet.

These Witch Hazels are the first of all woody plants to blossom; they are perfectly hardy, and every season, no matter how inclement the weather, put forth a wealth of flowers from the twenties of January to early March. Not on $\mathrm{y}$ are they excellent subjects for planting in parks and gardens generally, but they are particularly valuable for town gardens. City 
smoke does not affect them injuriously; they will withstand considerable neglect and abuse and may be kept in bounds by pruning. It is passing strange that plants so useful and so very desirable for enlivening gardens with flowers during dull winter months should have received so scant recognition.

The Spicebush (Benzoin aestivale) and Leatherwood (Dirca palustris), two common inhabitants of the thickets and swampy woods of New England and elsewhere on the Atlantic seaboard, are among the first of native shrubs to open blossoms. The Spicebush is a tall shrub with moderately stout stems and twiggy branches and bears innumerable clusters of small yellow flowers. The Leatherwood is a compact bush from three to five feet high, and much more in diameter, and has pale yellow, bell-shaped flowers.

A number of our earliest flowering shrubs hail from Europe and, with conspicuous flowers, the first to open are the Heath (Erica carnea) and the Mezereon (Daphne mezereum). The former opens its little pink urns in quantity even before all the snow has melted from around it. This and its white form (alba) are compact little plants from six inches to a foot tall and are absolutely hardy and easily grown, provided they be planted in positions fully exposed to the sun and air. The Mezereon is a woodland shrub but when once 
established thrives in the open border. It is a sturdy bush seldom exceeding four feet in height with erect branches, and in early spring its twigs, throughout their entire length, are covered with rose-colored or in case of the variety alba with white, fragrant flowers.

Very beautiful, too, is the Garland-flower (Daphne cneorum), a native of the Caucasus. This is a lowgrowing tufted plant not exceeding a foot in height, but densely branched and with gray-green leaves and terminal rounded clusters of rose-pink, deliciously scented flowers. The charming plant blossoms most profusely in the early spring, and through the summer and autumn a few flowers continue to open. Both for the rockery and open border this is a delightful subject.

For the most ornamental of early spring-flowering shrubs and trees, the gardens of eastern North America depend, not upon native nor upon European plants, but upon those of China and Japan. These lands, too, have their catkin-bearing Willows, Poplars, Alders, and Hazelnuts; their Elms, Maples, and other plants with flowers clustered on naked twigs. They have, in addition, a variety of shrubs and trees which have large and brightly colored flowers that are conspicuous from afar, and it is these that are 
found most commonly in our gardens and that we all admire so much.

Of all hardy trees Magnolias have the largest flowers, and no trees are more beautiful and few so amenable to cultivation. Now, Magnolias are confined to this country east of the Mississippi Valley, to eastern Asia and to the Himalayas. All the American species produce their flowers at the same time as the leaves or after the latter are fully unfolded. A similar group grows in the forests of China and Japan; but, in addition, there are species native of those lands which bear flowers abundantly on the naked shoots. It is these that give such a gorgeous display of blossoms in early spring and are everywhere so highly esteemed in gardens and parks. Centuries before their introduction to western lands these plants were favorites in the gardens of China and Japan, where their flowers are regarded as a symbol of candor and beauty.

The Yulan (commonly known as Magnolia conspicua, but correctly as $M$. denudata) is authentically known to have been cultivated in China since about 618 A.D. The white-flowered form of the Yulan was introduced to English gardens in 1779, and is now grown everywhere in the Occident. It grows wild in moist woods in the central parts of China, 
but this fact has only recently been made known. This form, however, is rare in a wild state and that most usually met has rosy or reddish-pink flowers. This variety has likewise been long cultivated in China and also in Japan, where it is known as Sarasarenge and in Japanese nursery catalogues as $M$. obovata, var. discolor; correctly, it should be $M$. denudata, var. purpurascens. In 1900 , I introduced this variety by means of seeds collected from wild trees in central China, but as yet the plants have not borne flowers. However, I strongly suspect that it has been cultivated in western gardens for a much longer period, under some other name, and its identity obscured.

Both the white and colored varieties of the Yulan are trees fifty feet tall, with a trunk eight feet in girth, and have ascending and spreading branches. Such trees I have seen in the forests of central China laden with thousands of flowers, and the spectacle they presented will never be forgotten. In western gardens examples of the white variety from twenty to twenty-five feet tall are known, and fine specimens are common in the gardens of eastern North America where the Yulan is a very popular tree.

The second species to be introduced to our gardens was the Purple-flowered Magnolia (usually known as 
$M$. obovata, $M$. purpurea or $M$. discolor, but correctly as $M$. liliflora), which reached England in 1790. This, like the Yulan, has long been cultivated in China and Japan, but it has not yet been authoritatively reported in a wild state. It is a much less hardy plant than the Yulan and appears to be always a shrub. In this country it is well known and thrives in gardens south of Philadelphia. The flowers are dark wine-red and very handsome. Under cultivation in Europe several hybrids between $M$. denudata and $M$. liliflora have been raised. The oldest and best known of these hybrids is Soulangeana, with flowers suffused with rose. This is a hardy and vigorous-growing tree and some very fine examples are known in this country. Others of these hybrids are rustica rubra, with deep rose-colored flowers; and Lennei, which originated in Italy, has rich crimson-purple flowers, and blossoms late. Both are strong-growing, freeflowering plants.

In 1862, Dr. George R. Hall, on his return from Japan, brought with him and handed over to Mr. S. B. Parsons, at Flushing, L. I., a collection of plants that have proved of immense value to gardens. Among the many good things was a Magnolia, which Parsons afterward distributed as $M$. Halleana to commemorate the name of its introducer. Unfortunately, how- 
ever, it had earlier received the name of stellata, and that had to take precedence. This $M$. stellata is the first of all Magnolias to open its blossoms and is always a broad and shapely shrub growing eight to twelve or fifteen feet high and more in diameter; the star-shaped, snow-white flowers are smaller than those of other species but are borne in such profusion as to cover the bush with white. This is one of the most beautiful and most satisfactory of all springflowering shrubs and is extremely hardy. There is also a variety (rosea), with delicate pink flowers, which makes a lovely companion to the type. A fourth species ( $M$. kobus) also hails from Japan, where it is common in the forests on the mountains throughout the greater part of that land. The southern and typical form is a large bush or low tree, but the northern form (var. borealis) is a shapely tree from sixty to seventy-five feet tall with a smooth trunk six feet in girth. This variety, borealis, was introduced in 1876 , by Mr. W. S. Clark and trees raised from the original seeds are now thirty feet tall and have broad pyramidate crowns. It flowered for the first time in cultivation in April, 1899, in the garden of Professor Sargent, Brookline, Mass., but the blossoms were sparse. In subsequent years it has flowered in many gardens and much more profusely, and it is the most 
free-growing of all members of its group. The pure white cup-shaped blooms are smaller than those of the Yulan. There are other species of Magnolia which flower on the naked twigs, but of these only two are in cultivation and only one, the Himalayan M. Campbellii, has blossomed. This has rose-colored flowers, and is one of the most gorgeous of all flowering trees but, unfortunately, it is less hardy than any other member of its group.

Magnolias grow naturally in moist, rich woods and, although they will withstand considerable hardship and abuse, the best results are obtained when they are protected from strong winds and are planted in deep soil rich in humus. In northern gardens the best time to transplant Magnolias is late in the spring. They may also be moved successfully about the end of August or beginning of September, but at either season they must not be allowed to suffer from lack of water and it is advisable to mulch them with well-decayed manure.

A favorite shrub in the gardens of China and Japan is the La-mei-hwa, widely known as Chimonanthus fragrans but correctly as Meratia praecox. This plant has fragrant, pale yellow, saucer-shaped flowers stained with wine color at the base, and these are freely borne on the naked shoots. It is not hardy 
in New England, but south of Washington, D. C., it thrives. Like many other plants cultivated in Chinese and Japanese gardens, this shrub is a native of central China where it grows naturally on cliffs and in rocky places.

For gardens south of Philadelphia the rambling Jasminum nudiflorum, with cear yellow flowers on naked shoots, is a lovely old plant. It is a native of northern China where also it is frequently cultivated, and is one of the plants we owe to the labors of Robert Fortune, who sent it to the Royal Horticultural Society in 1844.

In China and Japan, except the colder parts, the first flowers to open on deciduous trees are those of the Ume (Prunus mume), generally known as the Japanese Apricot, and those familiar with the porcelains of the Far East will appreciate it as the Plum Blossom so often employed in design. This plant is wild in central and western China, but it has been cultivated in all but the colder parts of that land from time immemorial and was from China introduced to Japan by Buddhist priests more than one thousand years ago.

In Tokyo and many other places in Japan there are famous "Plum Gardens" which are a source of great attraction when the trees are in blossom. 
At the village of Tsuki-gase, some twenty-five miles from the old eighth century capital of Nara, there is a line of Ume trees for upward of two miles alongside a small stream. The delicately fragrant flowers are white, pink, and even deep rose, and are either single or double; the shoots are smooth and green and the leaves roundish and light green in color. Normally it is a low bushy tree some twelve to fifteen feet tall, with a thin trunk and spreading branches; but under cultivation, forms have originated in which the branches are pendent or quite erect (fastigiate).

In both China and Japan it is much grown in pots as a dwarfed bush and in this condition flowers profusely. Cut branches with flowers are abundantly used for house decoration-so much so, in fact, that it is safe to say that in season where it is grown in China and Japan no temple, shrine, or dwelling-be it castle, palace, or peasant's hut-is without its sprig of Ume. Unfortunately, this plant is not hardy in the colder parts of North America, but south of Philadelphia it is not uncommon in gardens. It deserves to be more widely known, and as a forcing shrub merits the attention of florists.

The common Peach (Prunus Persica) is a native of central China and as bearing the finest of all the stone fruits needs no mention here. But cultivated in the 
gardens of China and Japan are a number of varieties with large and double flowers, in white, pink, rosered, and bizarre and strikingly handsome. From time to time these have been introduced into our gardens, yet one rarely meets with them, beautiful though they are. The explanation is that, like the parent stock, they are short-lived trees; but they are readily renewed by budding or grafting and our nurserymen ought to be able to keep our gardens supplied.

In addition to the common Peach two other species grow wild in China. One of these ( $P$. Davidiana) is confined to the northern parts of that country and in the Arnold Arboretum it is the first of its class to blossom. Often the flowers get damaged by frosts in the changeable climate of New England. The tree is of slender growth with thin ascending-spreading branches, and there are two forms, one with white and another with pink blossoms. The other species ( $P$. mira) is a new discovery which I made in 1910, on the Chino-Thibetan borderland. The flowers are unknown to me but probably resemble those of the common Peach. This new species is remarkable in having a very small, flattened-oval and perfectly smooth stone; its value, if any, as a new fruit has yet to be made known, but for the hybridist it certainly has attractions. 
The common Apricot (Prunus Armeniaca), its specific name notwithstanding, is also native of northern China and, like its allies, is not only a valuable fruit tree but is likewise a handsome and ornamental flowering plant. This, too, has been long cultivated in the Far East, and in Japan varieties differing in habit and color of flowers have originated. The type and its varieties are all very hardy and in New England gardens they are often cultivated under the erroneous name of $P$. mume.

In Japan this Apricot is known as Ansu and the fruit is pickled and is served as an appetizer; but under the same name the Japanese cultivate another species ( $P$. ansu), which is distinguished by the blade of the leaf tapering to a narrow wedge at the base. This species is native of Korea and has ascendingspreading branches and rigid shoots. In Japan forms with single and double white and pink flowers are grown.

In Mandshuria a third species of Apricot ( $P$. mandschurica) grows wild. This tree is distinct, with its light gray rather scaly bark, wide-spreading crown, and spiny inner branches. The flowers are large, white or nearly so.

Of Cherries proper the next chapter treats, but of several cognate plants it is convenient to speak 
here. All are twiggy bushes of rather low stature, are natives of China, and are among the eariiest of all shrubs to blossom. Two of these (Prunus japonica and $P$. glandulosa) are very doubtfully distinct as species, but the leaves are much broader in $P$. japonica, and rounded and somewhat heart-shaped at the base, whereas in $P$. glandulosa they are narrowed at the base. Both are twiggy shrubs from three to five feet high, and there are forms with white, pink and single, or double flowers. They are old inhabitants of our gardens and have long been cultivated in Japan but are not native of that country. In northern and central China they are common wild plants, and so, too, is P.tomentosa, also commonly cultivated in Japan but not indigenous there. This, likewise, is a fairly old denizen of western gardens. It is a spreading, extremely hardy shrub of moderate height and has red flower-stalks and calyx and pure white petals which are pink in bud. The shortstalked, Cherry-like fruit is scarlet, ripens in June, and is very palatable.

The last of the Prunus I shall mention and the most beautiful of the four is $P$. triloba, also a native of northern China. The double form (plena) is commonly cultivated in Peking gardens and is a general favorite in western gardens to which it was 
introduced in 1857. The flowers of this form are large, pink, and very freely produced on the naked twigs. More beautiful, however, is the type with its wealth of purest pink, single flowers. This wild form was sent from Peking to the Arnold Arboretum by Dr. E. Bretschneider in 1882, but is much too rarely seen in gardens.

Among spring-flowering shrubs yellow is a common color but in none is it purer or more vivid than in the Chinese Forsythias or Golden Bells. These lovely shrubs are universal favorites in northern lands and well do they deserve the honor. Of the two species (Forsythia suspensa and F. viridissima), the older and better known in gardens is $F$. suspensa, with its abundant clear yellow bells; but better than either is the hybrid between them ( $F$. intermedia), which has larger and richer colored flowers. There are several other hybrids and forms, all of them valuable garden plants, but the finest is the form spectabilis. These Forsythias are strong-growing shrubs, with arching pendent branches which overlap one another and form an impenetrable tangled mass. They are sun- and loam-loving plants and are seen to best advantage when planted where they have lots of room, and preferably on a slope, where they may develop unmolested. On such a slope in the Arnold Arboretum there is a tangle of 
Forsythias about seventy-five feet long and as much through and, as a feast of color and beauty in spring, is worth coming a long, long way to view. Any pruning considered necessary should be done immediately the flowers have fallen and, incidentally, this is true for all spring- and summer-flowering deciduous trees and shrubs.

A few years ago, in 1897 to be exact, a third species of Forsythia was discovered in Albania and was named $F$. europaea. This plant was introduced into Kew Gardens in 1899, and bids fair to grow much taller than its Chinese relatives and their progeny. It is upright in habit and in consequence very distinct in appearance. The flowers are pale canary yellow and the plant is a very hardy and interesting addition to the list of spring-flowering shrubs; but those who have only room in their gardens for one Forsythia and want the best available should plant the hybrid $F$. intermedia or its form spectabilis.

Among the Bush Honeysuckles (Lonicera), whose all-round value for our gardens has been repeatedly emphasized in these pages, there are species such as L. fragrantissima and $L$. Standishii which open their blossoms at the first breath of spring. Both are compact shrubs growing from four to eight feet tall and more in diameter, and have pale yellowish-white 
sweetly fragrant flowers which are followed by scarlet fruits.

Rhododendrons, including Azaleas, will be dealt with in a subsequent chapter but it is permissible to mention here Rhododendron mucronulatum and $R$. dahuricum. These are deciduous shrubs growing from four to eight feet high and are the earliest of their class to blossom. The flowers are pink or rose in the former, and rose-purple in $R$. dahuricum. They are natives of cold regions of Mandshuria and Korea, and in New England the flowers are often nipped by late frosts. Both are sparsely branching, and to obtain the best effects they should be massed together thickly in a situation exposed to the air but protected from cutting winds and the early morning sun. 


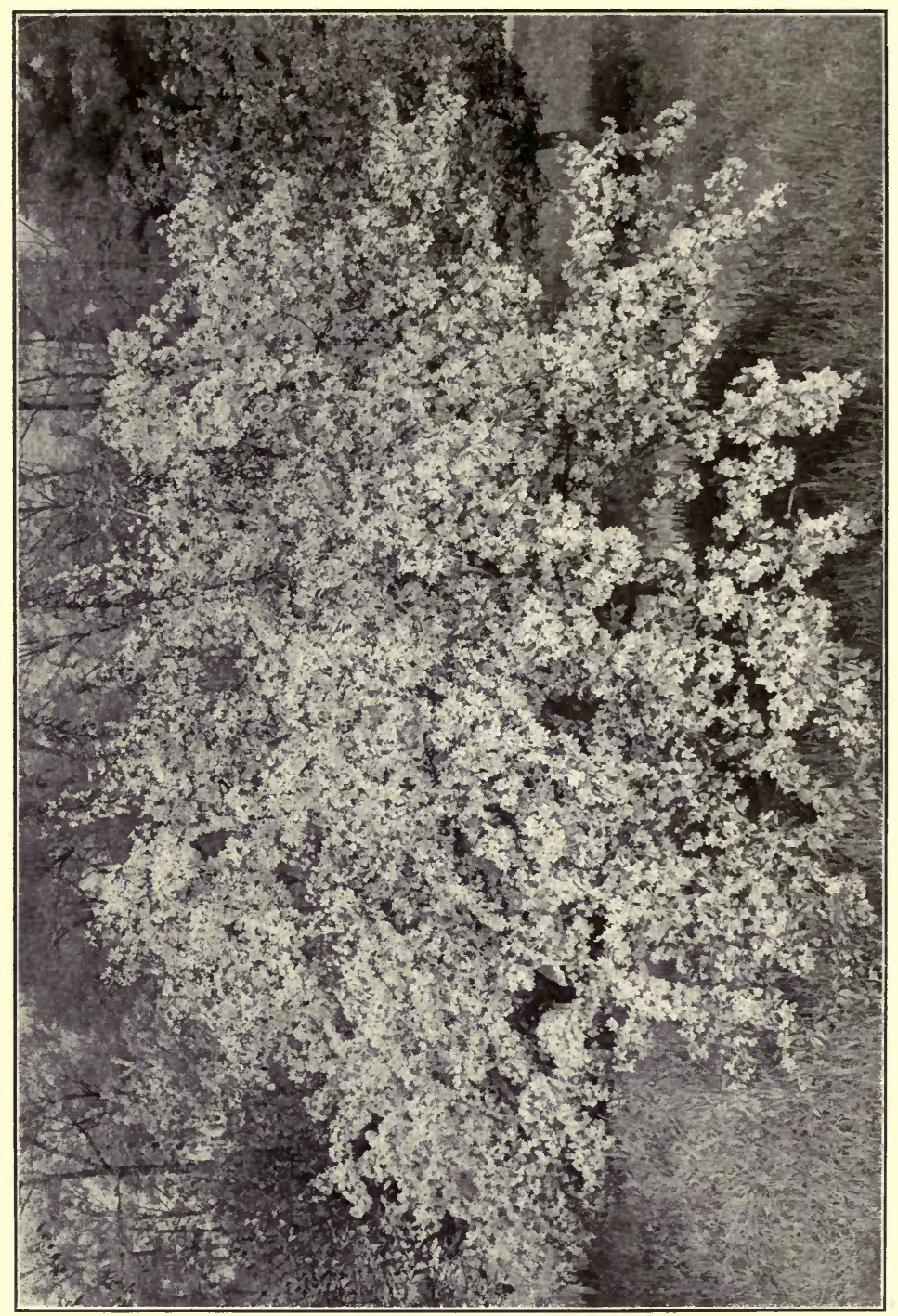

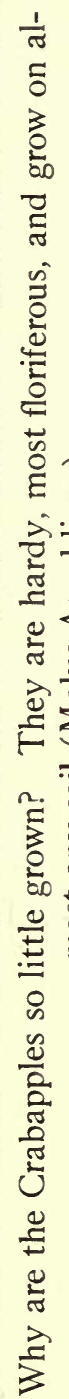




\section{CHAPTER XI}

\section{JAPANESE CHERRIES AND ASIATIC CRAB- APPLES}

MANY OF THESE ARE ALREADY WELL KNOWN AND YET RARELY PLANTED IN OUR GARDENS-THE NOMENCLATURE IS HERE SET RIGHT AND THEIR IDENTIFICATION IS MADE EASY

HE group of plants now to be considered is not exceeded in beauty and hardi-

L ness by any other, and yet its members are comparatively rarely seen in American gardens. A few are fairly well known to older garden lovers and here and there in city parks, like those of Rochester, N. Y., several may be seen in all their beauty. But truly there should be no garden, even a suburban garden, without its Flowering Cherry and its Crabapple tree.

When I think of the popularity certain plants of much less lasting value have attained I cannot help thinking that it is want of knowledge and not want of appreciation that has kept in the background the extremely ornamental plants with which this chapter deals. If any reader will visit the Arnold Arboretum 
in late April and May, and see the collection of these plants in blossom, he will depart hungry for them and will not rest content until one or more be growing in his own garden.

In the cooler parts of the temperate regions of western lands there is no more beautiful sight than the Apple orchards in full blossom in the spring unless it be the same orchards in autumn laden with ruddy fruit. But the utilitarian is apt to stifle the æsthetic spirit in so far as this and other familiar sights are concerned. The common Plum and the common Cherry suffer in the same way, yet the winsome beauty of their flowers is undeniable. Again, an orchard of Peach trees in bloom is wondrously pretty though the trees have not the picturesque appearance of aged Apple trees.

However, if familiarity has dulled spontaneous enthusiasm for the floral charms of these indispensable fruit trees none, when taxed with the question, will attempt to deny their effective beauty. It is with the near relatives - the brothers, sisters, and firstcousins - of these familiar fruit trees that I am about to treat here, and since the fruits they produce have no comestible value we can drink in their charms uninfluenced by the pernicious alloy of utilitarianism. But do not misunderstand me: I am not denying the 
indispensable value of our fruit trees as such nor their extensive and extended culture. Quite the contrary. But the creed of the true horticulturist is founded on that old Biblical truism- "man cannot live by bread alone."

Any attempt to portray in words that marvelous floral spectacle known in Japan as the Cherry Festival, fails lamentably. It must be seen to be appreciated, but no language can exaggerate the beauty of the Japanese Cherries. Readers who have visited Japan and have basked in the loveliness of the Cherry blossoms must have yearned deeply to possess some of the trees. Such feeling is natural. We should have these Japanese Cherries in our gardens and there is no valid reason why here in eastern North America we should not have our own Cherry festival, for the trees are perfectly hardy and thrive here. In the Arnold Arboretum the few large examples we have produce a wealth of flowers each and every season.

\section{THE CHERRIES}

Of flowering Cherries the Japanese recognize a hundred or more varieties with white, yellow, pure pink to rose-colored blossoms. Some are small shrubs, others large trees with wide-spreading crowns; some have pendent and others quite erect branches. 
All are entrancingly beautiful. Cherry trees grow wild in the woods and thickets throughout the length and breadth of Japan and they are everywhere planted in vast numbers-in temple and castle - grounds, in park and garden, in the streets of the cities and alongside the highways, by pond and by river-side. At Koganei, a village some ten miles from Tokyo, there is a three-mile avenue of Cherry trees, planted in 1735 by command of the Shogun Yoshimune. Many of the trees are from sixty to seventyfive feet tall, with trunks from ten to twelve feet in girth, and crowns from fifty to sixty feet through, and when in full flower the scene presented is a never-tobe-forgotten one.

As one result of its recent expedition to Japan the Arnold Arboretum has now growing a collection of more than seventy varieties of these Cherries and in a few years the American public will have an opportunity of appreciating the attractive charms of these plants. Meanwhile, the following kinds of proven merit should be grown by all who love a hardy plant.

The first of these Cherries to open its blossoms is Prunus subhirtella, the Higan-sakura or Spring Cherry of the Japanese. This is a low bushy tree, rarely more than from eighteen to twenty feet tall, with thin, ascending-spreading branches and a dense mass of 
twiggy branchlets, the whole forming a flattened or flattened-oval crown from twenty to thirty feet through. The flowers are silvery pink and are produced in such profusion as to hide completely the twigs and branches. This Cherry was introduced to cultivation by the Arnold Arboretum in 1894.

The Weeping Cherry (P. subhirtella, var. pendula) has flowers similar to the foregoing to which it is very closely related, but it is a much larger tree, growing from sixty to seventy feet tall with a trunk from ten to twelve feet in girth, and massive spreading limbs dividing into branches which curve downward and into slender whip-like pendent shoots. It was introduced into cultivation by Philip Franz von Siebold who secured plants for his nursery at Leiden, Holland, from Japan about 1863. It is a long-lived tree but I have never seen a good example in the Occident. In Japan, and especially in the temple grounds, magnificent specimens are common and there is no more graceful or beautiful tree than this Weeping Cherry. The Japanese called it Shidare (Hanging) or Itozakura (Thread Cherry) on account of its very slender, whip-like pendent branchlets.

The Cherry so abundantly grown in and around the city of Tokyo and whose season of blossoming is made the occasion of a national holiday is the Yosh- 
ino-sakura ( $P$. yedoensis). This is a large, quickgrowing tree which at its best is from forty-five to fifty feet tall with a trunk from six to eight feet in girth and massive spreading branches forming a rounded crown from sixty to seventy-five feet through. The fragrant flowers are larger than those of the preceding two Cherries, and vary in color from pure pink to white. If crowded together the trees grow taller, but the crowns are narrow and much less shapely. It was introduced into the Arnold Arboretum in 1902, from Tokyo, and the seedlings have grown very rapidly.

The most beautiful of all the wild species of Asiatic Cherries is $P$. serrulata, var. sachalinensis, better known as $P$. Sargentii. This is a native of the northern and colder parts of Japan and has large, pink to rose-colored flowers and the young unfolding leaves are a ruddy brown. It is a large and longlived tree and the avenue at Koganei mentioned previously is of this species and its varieties. Dr. William Sturgis Bigelow sent seeds from Japan to the Arnold Arboretum in 1889, and trees raised from these seeds are now twenty-five feet tall with trunks four feet in girth and crowns thirty feet through. Nearly all the Japanese Cherries with double rose-colored flowers are forms of this species, and it is the stock 
on which all of that class should be grafted or budded in order to make them long-lived trees in this climate.

One of the loveliest of these rose-colored Cherries with double flowers is known in western nurseries as "James H. Veitch." The Japanese name for it is Fugenzo and there is also a white counterpart (albo-rosea) which is styled Shirofugen. These two are distinguished from all others of this class in having two tiny green and folded leaves in the centre of the majority of their flowers as is the case in the double-flowered form of the European P. Cerasus.

Two other Japanese Cherries are $P$. Sieboldii and $P$. Lannesiana. The first named has rose-pink, double or semi-double flowers and its leaves are clothed with soft hairs. In nurseries it is sold as "Watereri" and as "Naden." The other species has many aliases and in its different forms is sold as $P$. pseudo-cerasus and as $P$. serrulata, names, however, to which it has no proper right, and which have proved a great bugbear and hindrance to our proper appreciation of the garden varieties of Japanese Cherries generally. In typical $P$. Lannesiana the flowers are pinkish but its wild form has pure white blossoms. All the numerous forms of this Cherry have fragrant flowers and they are mostly white or pale pink. One sort (Grandiflora or Ukon) has clear yellow flowers 
and in another (Gioiko) the color is yellow with a green band down each petal. In both the flowers are double. Prunus Sieboldii and P. Lannesiana together with their forms are trees from twenty to thirty feet tall, with wide-branching heads, and in Japan they grow rapidly but are not long lived.

In the Occident we have not been very successful in cultivating the double-flowered forms of these Japanese Cherries and from information gained during my recent visit to Japan I am convinced that our want of success heretofore has been due to the fact that for our climate they have always been grafted on the wrong stock.

All the single-flowered sorts of these Japanese Cherries fruit freely with us and should be increased by seeds, for seedling trees of these Cherries grow more freely and more satisfactorily than those raised by other means. All the double or semi-double flowered kinds should be grafted or budded on $P$. serrulata, var. sachalinensis. If this be followed I make bold to say that these Cherries will thrive as well, grow as freely, and live as long as they do in Japan.

One other species of Japanese Cherry deserves mention and that is $P$. incisa, which is abundant on the lower slopes of Fuji-san and the immediate 
vicinity, but is confined to those regions. It is a bush or small tree from five to thirty feet tall with ascending and spreading thin branches and twiggy branchlets and pale pink to pure white flowers. This Cherry blossoms profusely in a small state and is the only kind the Japanese dwarf and grow in pots, and on this account they designate it the Mamezakura (Dwarf Cherry).

All the Japanese Cherries make excellent specimens on lawns where they are seen to good advantage. The smaller growing kinds may be massed together for telling effect whilst for avenue trees $P$. serrulata, var. sachalinensis and $P$. yedoensis cannot be surpassed. They thrive best in a light loamy soil but like all their kin they are subject to attacks of scale insects. These pests may easily be kept down and the trees maintained in good health by spraying in late winter with lime-sulphur (one gallon to eight gallons of water) or with miscible oil (one gallon to fourteen gallons of water).

\section{THE CRABAPPLES}

In horticultural and botanical literature the Crabapples are often referred to as "Pyrus (something)" but nowadays it is customary to speak of them under the generic title of Malus and to restrict that of Pyrus 
to the Pears, and this is followed here. My intention is to tell here of the Crabapples of eastern Asia, but there are also several very beautiful species of Crabapple native of this country-as for example, $M$. angustifolia, $M$. fusca, $M$. glaucescens, $M$. coronaria, $M$. ioensis and its form, known as the Bechtel Crab, which has large and fragrant double pink flowers that look like Roses and excite the interest and admiration of all beholders. The American Crabapples blossom later than their Asiatic relatives and both groups deserve the widest recognition.

The Siberian (Malus baccata) is the oldest known but one of the Asiatic Crabapples, having been introduced into Europe in 1784. It is a tree from thirty to forty feet tall, with stout, spreading branches and slender branchlets which form a broad rounded or more or less oval crown. The flowers are pure white and delightfully fragrant and are profusely borne in clusters; the fruits are small, yellowish, or yellowbrown. This tree is widely dispersed in the cold northern parts of eastern Siberia and extends southward into Mongolia, Mandshuria, and extreme northern China. It is the most northern of its class and the hardiest of all species of Malus and for this reason ought to be used in the colder parts of this country as a stock for the common Apple. In the littoral regions 
of northeastern Siberia, in Korea, and in northern Japan, this species is represented by its variety mandschurica which differs in certain technical points and has scarlet fruit. In Korea there is a form (Jackii) which has handsome, relatively large dark red fruit. Under cultivation numerous hybrids between Malus baccata and the common Apple and other species have arisen and all are ornamental in flower and exceedingly beautiful in fruit. They are known collectively as Siberian Crabapples but many of the varieties have received distinctive names.

The oldest known of the Crabapples is the Chinese $M$. spectabilis which was introduced from Canton into England in 1780. It is cultivated in the Imperial gardens at Peking and elsewhere in China, but has not yet been reported in a wild state. It is a small tree from twenty to thirty feet tall with a vase-shaped crown made up of numerous rigid ascending branches and short branchlets. The flowers are pale pink, more or less semi-double and fragrant, and the fruits are yellow, nearly globose, and about three quarters of an inch in diameter. The habit is rather stiff, but this old denizen of gardens with its wealth of clustered blossoms is strikingly beautiful.

A lovely Crabapple bearing in season its pale pink flowers in the utmost profusion is M. Scheideckeri. 
This is also a small tree, loosely pyramidal in habit and of hybrid origin and one of its parents is assumed to be $M$. spectabilis.

The next species to make its début in this country is the celebrated Parkman Crab (M. Halliana) which was sent from Japan to the United States by Dr. George R. Hall in 1861, and first cultivated by Francis Parkman, the historian, in his garden on the shores of Jamaica Pond, Boston, Mass. This is a tree-like shrub with a broad, bushy crown and twiggy branchlets and rather thick, dark green leaves deeply tinged with bronze color where they unfold. The flowers, each on a long slender stalk, are borne in clusters and are bright rose color, and these are followed by pealike dark greenish red fruit which ripen very late in the fall.

In a family so beautiful as the Crabapple there is room for divergence of opinion as to which is the finest, but many (of which I am one) consider the Parkman Crab the most winsome of all the Asiatic species. The type has flowers single or nearly so, but there is a form (Parkmanii) which has double or semi-double flowers. This lovely plant has long been a favorite in the gardens of the flower-loving Japanese who call it the "Kaido," but like many plants cultivated in Japan it is of Chinese origin. 
In 1904, I had the pleasure of discovering it growing wild in thickets on the frontier of western China and Thibet and collected seeds from which plants have been successfully raised.

A very desirable plant is $M$. atrosanguinea which is a hybrid presumably between $M$. Halliana and M. Sieboldii. It is a broad shrub growing ten feet or more high with thin spreading and arching branches and rose-pink flowers.

Perhaps the best known of the Asiatic Crabapples is $M$. floribunda, which was introduced about 1853 , by von Siebold, into Leiden in Holland, yet its native country remains unknown to this day. Presentday Japanese botanists seem unacquainted with this plant and both they and Japanese nurserymen confuse it with the Parkman Crab, and during my trip in Japan I never met with it. However, since our gardens are in fortunate possession of it we can waive the more academic question of its habitat. It is a broad, round-topped, tree-like shrub sometimes twenty-five feet tall, and as much in diameter, with slender arching and pendent branchlets. The clustered flowers are pure white when expanded and bright rose color in bud, and as they open in succession the contrast is singularly beautiful. The fruit is about the size of a pea, yellowish or yellow-brown 
and long persistent but not attractive except to birds which appear especially fond of it.

In gardens all the species of Malus hybridize freely and the group offers a field of immense interest to those who will breed and select the offspring. Some years ago there appeared in the Arnold Arboretum among a batch of presumed seedlings of $M$. floribunda a very distinct plant which has been named $M$. Arnoldiana. It is probably a hybrid between $M$. floribunda and $M$. baccata, but whatever its origin it is certainly one of the most lovely of all Crabapples. The habit is similar to that of $M$. floribunda but the flowers though of the same color are one half larger and the fruit, too, is much bigger. A friend of mine who lives at Winchester, Mass., has a fine specimen of this hybrid growing under the lee of his house and no one has yet been able to persuade him that there is any other kind of Crabapple which approximates to this in beauty.

At the same time as von Siebold introduced the gem $M$. floribunda he also introduced another Crabapple (M. Sieboldii, better known as M. toringo). This is a low dense shrub of sprawling habit with lobed leaves, small flowers, white tinged with rose in color, and small yellow fruit. It is really a scrubby form of a species widely distributed in Japan and horticultur- 
ally inferior to its real type, now known as var. arborescens, which is a small tree with ascending and spreading branches, twiggy branchlets, and fruit yellow or red on different individuals. Another variety (calocarpa), raised from seeds sent in 1890 to the Arnold Arboretum from Japan by Dr. William Sturgis Bigelow, has handsome bright red fruits half an inch in diameter and is in fruit the most strikingly beautiful of all Crabapples.

Differing from the tree form of $M$. Sieboldii only in certain technical matters is $M$. zumi which was introduced to cultivation by Professor Sargent who collected seeds in Japan in 1892. This, too, is a very desirable small tree with fragrant white flowers and small yellow or red fruits. It is common on the slopes of Mt. Fuji and on the shores of Lake Chuzenji in the Nikko region.

Most of the orchard fruits grown in the countries of the Far East have been obtained by long cultivation from species indigenous in China and have not common origin with the same kinds of fruits cultivated in this country and in Europe. The Apple of that region is an example. It is only very recently that science has become acquainted with the source of the Apple of China and Japan although under various names it has been in cultivation in the Occi- 
dent for some sixty years. This Apple ( $M$. prunifolia, var. rinki) grows wild in the mountainous parts of central China where I was fortunate enough to discover it in the spring of 1901 , and later secured seeds which resulted in its successful introduction to our gardens. Previous to this discovery it was known only from plants cultivated in Japan, and by most botanists was considered a very doubtful plant. From Japan it was introduced to Europe about 1854, and distributed by von Siebold as Malus ringo. In habit this species resembles the common Apple but its leaves are rather different, the flower stalks are much longer, and the fruit is not impressed at the summit. As a fruit tree the Chinese Apple is cultivated in central and western China, from river level, where the climate is very warm, to altitudes of 9,500 feet in the more mountainous parts, where a severe climate obtains. In northern China and Korea it is cultivated sparingly over a wide area. The fruit is small, seldom more than one and one fourth inch in diameter and slightly longer than broad, of a pleasant bitter-sweet flavor and varies in color from greenish to greenish yellow and is rosy on one side. Occasionally it is nearly all red. Formerly this Chinese Apple was cultivated in Japan for its fruit, but since the introduction of varieties of the 
European Apple its cultivation as a fruit tree has been discontinued.

There are other species, too, of much merit and beauty and several new ones whose value we do not fully know, but there is one so distinct in habit and with a field of usefulness so peculiarly its own that it must not be omitted even in this incomplete enumeration, and that is M. Sargentii. This species is of dwarf stature with the branches rigid and spreading, and the lower ones flat on the ground, and is eminently suitable for covering slopes and banks. The flowers in umbellate clusters are saucer-shaped, round, and of the purest white and these are followed by masses of wine-colored fruit which is covered with a slight bloom. In its habit, its flowers, and in its fruit it is very distinct from all other species. We owe this valuable addition to Professor Sargent, who discovered it in fruit and sent seeds in 1892, from near Mororan in Hokkaido, Japan.

In this group of Asiatic Crabapples there are trees for the avenue, park, or garden, shrubs for the lawn or border and others suitable for slopes and banksall absolutely hardy in the coldest parts of New England and each and all may be depended upon to produce every spring season a wealth of blossoms in veritable cascades. The plants grow quickly in 
good loamy soil and many of them begin to flower and produce fruit when only a few years old. They will thrive wherever the common Apple will grow if attention be paid to keeping them free from the scale insects which are destructive to all plants of the Apple tribe. This may be accomplished readily by spraying with the same antidotes as recommended in the case of the Japanese Cherries. 


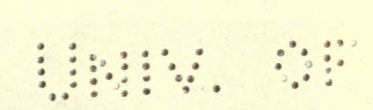

औ 


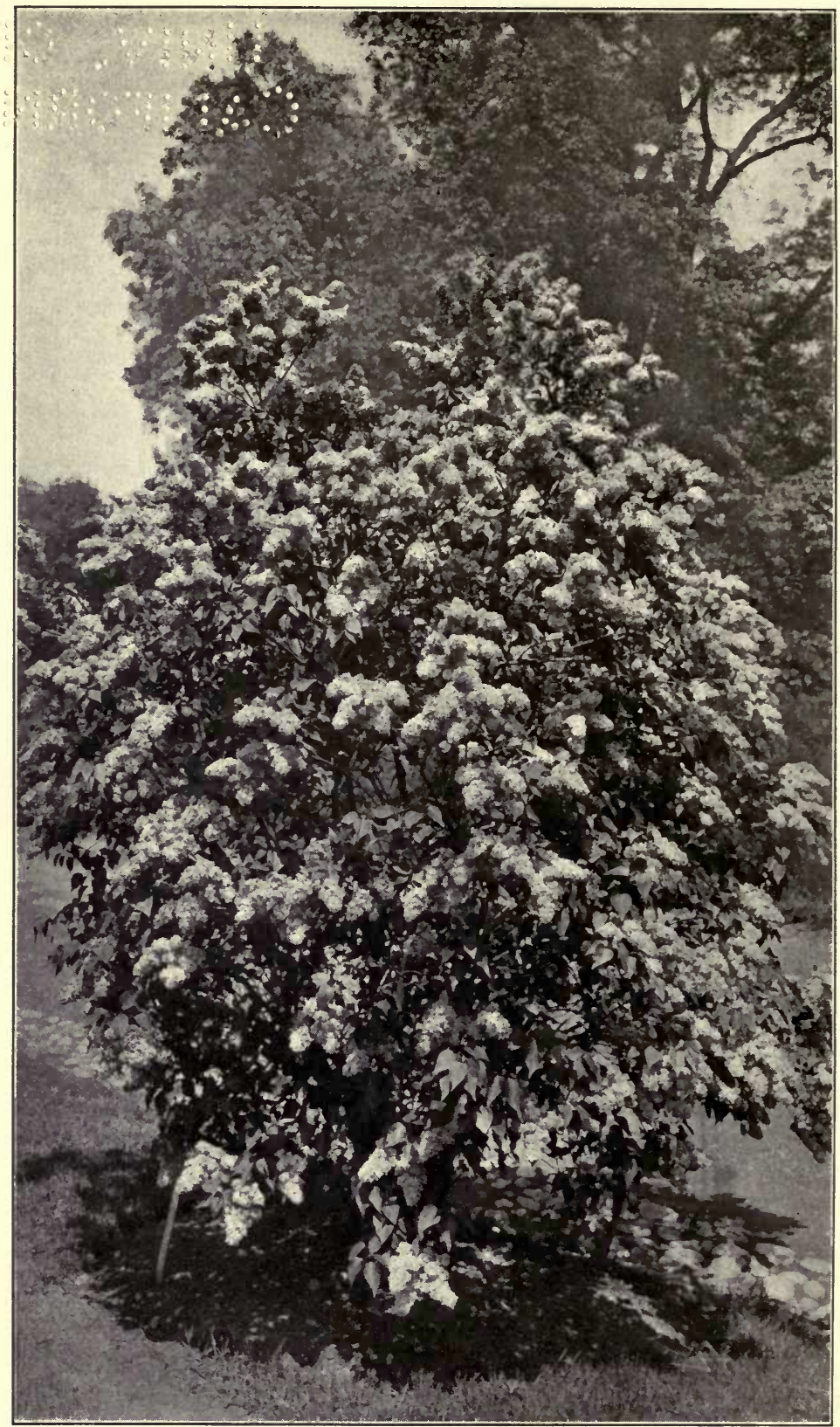

The common Lilac is known in a great number of varieties, with flowers ranging from white to dark purple. Given sufficient space they are clothed with their fragrant flowers. The variety shown here is Congo 


\section{CHAPTER XII \\ IN "LILACDOM"}

THE MOST ADAPTABLE GROUP OF FLOWERING SHRUBS FOR FLORAL USE

TILACS are among the few hardy shrubs that have truly entered into their kingdom in the gardens of eastern North America. They need no introduction to readers and well they merit their popularity. For regions where cold winters are followed by hot, dry summers they are ideal shrubs. The Common Lilac (Syringa vulgaris) is the most accommodating of plants and thrives in all sorts of queer places and under all sorts of adverse conditions, but its progeny and its congeners are more exacting, and if good results are expected the plants must be treated liberally.

Now, the Common Lilac is native of the mountains of Bulgaria and was sent from Constantinople to Vienna about 1560. From there it soon reached western Europe and both purple and white kinds were cultivated in London in 1597, by Gerard. It is not known with certainty when, or by whom, this 
Lilac was introduced to North America, but Washington wrote about it in his diary and planted it at Mt. Vernon where his plants or their descendants are growing to this day. But although so long cultivated in gardens it is only recently that its native habitat has become known. In the Arnold Arboretum may be seen growing specimens raised from seeds gathered from wild plants. They have narrow clusters of dull-purplish flowers and are by no means attractive garden shrubs.

During the last fifty years horticulturists, especially those of France and in a lesser degree those of Germany, have paid great attention to the Common Lilac and the result has been a plethora of beautiful shrubs. In fact, virtually all the plants known in a general way as Lilacs have been derived from $S$. vulgaris. I shall recur to this point later, but it may be stated here that the possibilities of improving upon the present-day forms of the Common Lilac appear to be few but there are other members of the kingdom possessing vast potential values.

The Lilacs, of which some twenty-five species are known, are all native of the Old World and some are shrubs and others small trees. The Common Lilac (S. vulgaris) and its Hungarian confrère (S. Josikaea) are native of southeastern Europe; the Persian Lilac 
grows wild in southwestern Asia from the Caucasus to Afghanistan, and in the western Himalayas S. emodi is found. All other known species are natives of eastern Asia and no fewer than seventeen species are indigeneous in China proper. Only one species ( $S$. japonica), and that a Tree Lilac, is found in Japan. In the gardens of Peking and of other places in northern China the white-flowered $S$. affinis has been cultivated from time immemorial.

All Lilacs are very hardy plants, and, notwithstanding, the fact that none is native of this country every species so far brought into cultivation has proved hardy in the Arnold Arboretum. When their wide range of distribution is duly considered this is remarkable. In very severe winters the Himalayan $S$. emodi suffers somewhat and the flowers of the Chinese $S$. oblata are occasionally injured by late spring frosts but no other sort is hurt. And not only are Lilacs quite hardy in the colder parts of New England and elsewhere but they thrive better there than they do across the water in Great Britain.

As mentioned already the ordinary colored and white forms of the Common Lilac will withstand considerable hardship and abuse but their progeny to give the best results demand a good soil and this is true for all the other species. A well-drained, good, 
rich loamy soil suits them best and if the soil contains a certain amount of lime so much the better, for Lilacs generally are fond of lime. Full exposure to the sun and air is necessary and their beauty is displayed to best advantage when the plants are allowed a sufficiency of space in which to develop freely. They are essentially plants for northern New England and regions with a similar climate; in southern New England and southward the leaves in summer are often temporarily disfigured by mildew.

A decade or a little more ago it was customary to propagate Lilacs by grafting them on Privet (Ligustrum) stock, but this pernicious practice has met with the opprobrium it merits and to-day any dealer selling plants so propagated deserves to be ostracized. It is the nature of most Lilacs, and of the Common Lilac in particular, to sucker freely and this alone demonstrates the necessity for their being on their own roots. If the plants get unshapely or too large, own-root Lilacs may be cut almost to the ground with advantage for they will spring up and soon make shapely bushes again. Cuttings three to four inches long of green wood taken in early June, or of thin but firm, half-ripened wood taken from mid-July to early August, and inserted in prepared soil or sand on a spent hotbed, or in pure sand in a frame and kept close, 
will root in about six weeks, and in three years make nice plants. Also they may be budded or grafted on seedling stock of the Common Lilac and by this method, although it is not to be recommended, salable plants are produced in two years. When potting the stocks carefully remove all adventitious buds; suckers should not be used as stock since it is impossible in these to control the development of adventitious buds. But, after all, there is no valid reason for propagating Lilacs other than by cuttings for by this means the particular variety is on its own roots and the advantage to the garden lover is obvious and lasting.

In the Arnold Arboretum about one hundred and twenty named varieties of the Common Lilac are cultivated and in addition some twenty species and several hybrids, and the season of flowering lasts from about the first of May to the first week of July. In Highland Park, Rochester, N. Y., where great attention has been given to these plants, there is the most complete collection of the varieties of the Common Lilac to be found anywhere on this continent. In all, this park has two hundred and ninety-seven kinds of Lilacs and on May 22, 1915- "Lilac Sunday" -between the hours of six A. M. and eight P. M. some fifty to sixty thousand people visited this collection. 
Such collections are of great interest and of much educational value; but private gardens cannot accommodate such numbers.

If the best only be desired no such quantity is necessary, for within the limits of a dozen the best and most desirable kinds of the Common Lilac may be had. In recent years many of the seedlings raised and named and sold by nurserymen show no improvement on the older varieties. The beauty limit appears to have been reached and it is evident that no great additional improvement can now be expected from seedlings of the Common Lilac. But granted that a dozen will include all that is best in these plants the selection is onerous and difficult since individual taste is all important. Some people do not like the double-flowered sorts and others have preferences for certain shades of color. I am without prejudice or bias in these matters and of the sorts of the Common Lilac of proven merit in the Arnold Arboretum I would select the following dozen: Marie Legraye, Princess Alexandre (single white); Madame Lemoine, Miss Ellen Willmott (double white); Gloire de Moulins, Macrostachya (pink); Charles X (rosy lilac); Volcan, Congo, Philemon, Ludwig Späth (dark redpurple); Justi (blue). Be it understood all these are forms of the Common Lilac and it is not supposed that 
this selection in its entirety would satisfy every enthusiast.

But the Common Lilac and its very numerous descendants do not exhaust Lilacdom. Far from it - very far from it. There are other species and there are hybrids of singular beauty and charm which deserve wide recognition. Some blossom earlier than the Common Lilac and its forms, and others later; together they extend very considerably the Lilac season. Further, it is in the hybridizing of these species that advance in this useful and pleasing class of plants must be looked for in the future. As we shall see later a beginning has been made and our gardens enriched thereby.

Each succeeding year in the Arnold Arboretum there is a close race between two Chinese species (S. affinis and S. oblata), to be the first Lilac to blossom and usually the first-named wins. This has white flowers and is very abundantly cultivated in the gardens of Peking, and from there was introduced into the Arnold Arboretum by Mr. S. T. Williams in April, 1904. It is a tall bush of loose, irregular habit and has thin branches and sweetly fragrant flowers. The wild prototype of this Lilac was recently discovered in northern China and named var. Giraldii, after Père G. Girald, an Italian priest of the 
Roman Catholic Church, and reached us through V. Lemoine et Fils in 1906. This has mauve-colored flowers which open about the same time as the type. The other species ( $S$. oblata) is a sturdy and broad shrub of good habit and has handsome leaves, thick and leathery in texture, which in the autumn turn to a deep, bronze-red or wine color. The flowers are large, pale lilac, and very fragrant but unfortunately they are often injured by late frosts. It was introduced into England by Robert Fortune from Shanghai about 1854. In Peking gardens it is much cultivated and Dr. E. Bretschneider sent seeds from Peking to the Botanical Garden, Petrograd, where plants from this source flowered in 1888.

The next Lilac to open is $S$. pubescens, also native of northern China, and was introduced in 1882 by Dr. E. Bretschneider who sent seeds to the Arnold Arboretum, where it flowered for the first time in 1886. This is a free-growing and free-flowering shrub with erect and rather slender stems, small hairy leaves, and large clusters of pale lilac, fragrant, long-tubed, and rather small flowers with dark violet anthers and is among the most beautiful of all Lilacs. These three Chinese species are the heralds of Lilacdom. In rapid succession follow the Common Lilac with its numerous progeny and several other species. 
After the Common Lilac has finished flowering, or nearly so, the Persian Lilac (S. persica), with its huge clusters of small fragrant flowers which weigh down the slender branches, assumes the throne. This lovely Lilac was cultivated in England as early as the middle of the seventeenth century but it is now all too seldom seen in gardens. In cultivation it is a broad and shapely bush of medium height with small leaves and is extraordinarily floriferous. The type has pale rosy purple flowers, and so, too, has the form laciniata with deeply incised leaves, but there is also a white-flowered variety ( $a l b a)$.

Closely related to the Persian Lilac is $S$. pinnatifolia, a new-comer which I had the pleasure of discovering on the borders of China and Thibet and of introducing to cultivation in 1904. This species is remarkable in having pinnately divided leaves and in this character is distinct from all others. It has small pale mauve-colored flowers which are borne in broad pyramidate clusters; but thus far, under cultivation, it has not flowered freely and unless it improves with age it will have to be considered more in the light of a curiosity than anything else.

The most distinct of all Lilacs is the new $S$. reflexa with narrow, cylindrical flower clusters from nine to twelve inches long which arch downward from near 
the base and thus hang somewhat like the inflorescence of the Wistaria. The expanding flower-buds are bright red and the open flowers are pale rose color. It will thus be seen that this is a plant of singular and most distinctive beauty and in the hands of the hybridist may be the forerunner of a race totally different in aspect when in flower from present-day Lilacs. A strong-growing shrub from eight to twelve feet high, with erect stems and oblong lance-shaped leaves, its season of flowering is mid-June. It is native of the margins of woods and thickets on the mountains of western Hupeh, in central China, where I had the good fortune to discover it in 1901, and of introducing it, together with another new species (S. Julianae), in 1902. The latter is a broad shrub scarcely exceeding five feet in height but is twice that much in diameter, and has thin and twiggy branches and small, softly hairy leaves. Its rather small clusters are very freely produced and the flowers are small and fragrant and have violet-colored anthers. It differs from all other Lilacs in having the stalks of the inflorescence and of the individual flowers and also the outer surface of the corolla-tube a deep purple color. The inner surface of the corolla is white so that as the flowers open the inflorescence is purple and white and the contrast is most pleasing 
and is heightened by the dark violet anthers. It flowers toward the end of June.

A late-flowering species which under cultivation has yet to show its qualities in perfection is $S$. tomentella. I saw this plant in flower for the first time on July 9, 1908, on the frontiers of eastern Thibet at an altitude of nine thousand feet, and I thought then that I had never before seen such a handsome species of Lilac. It had foot-high, broad panicles of pink to rosy lilac colored flowers and on other bushes they were white. The plants were from eight to fifteen feet high, much-branched yet compact in habit, and the wealth of flower clusters made it conspicuous from afar. The leaves are elliptic-lance-shaped or rather broader, from four to six inches long and more or less hairy on the underside. In 1903, I had collected in the same locality seeds of this Lilac and successfully introduced it to cultivation. Being rather variable in certain characters it has received several names ( $S$. Wilsonii, $S$. Rehderiana, S. alborosea), but it must be known by its oldest name of $S$. tomentella. Under cultivation it has flowered several times and I am patiently waiting for it to show its real character.

Of the late-flowering Lilacs the best known in this country and perhaps the hardiest of all is $S$. villosa, 
a native of northern China; and from near Peking, introduced by Dr. E. Bretschneider into the Arnold Arboretum in 1882. It is a large shrub of excellent habit with erect fairly stout branches and oblong-lanceshaped, rather pale green leaves. The flowers are rose-colored, pink, or nearly white, but they have an unpleasant odor. It is, however, a first-rate garden shrub, exceedingly floriferous, and very valuable for its hardiness and for its late flowers. Very similar in habit to the above but with bluish purple flowers is the Hungarian Lilac (S. Josikaea) and though much inferior to its Chinese relative as a garden shrub it has proved valuable as a parent as we shall see when we come to the hybrids.

Of all late-flowering Lilacs the most strikingly handsome is $S$. Wolfii, native of Mandshuria and introduced into cultivation at Petrograd by Russian botanists. From there it was sent to the Arnold Arboretum in 1906, before it had received a name. In foliage and habit it resembles $S$. villosa but it is much more vigorous and a taller plant. The flowers are small, dark blue-purple to rose-purple and are borne in erect, branched clusters often two feet high and a foot broad and are produced in great profusion. Unfortunately the flowers lack the fragrance of the Common Lilac and of several of the Chinese 
species but in spectacular beauty it transcends them all.

The Himalayan Lilac ( $S$. emodi) is among the last of the true Lilacs to flower and is less hardy than any other. It is a large bush, or bushy tree, occasionally eighteen feet tall, with oblong, pointed leaves, light yellow-green above, silvery gray, and hairy below, and bears long, narrow clusters of small white fragrant flowers. In its pale foliage it is distinct from other Lilacs and it is one of the very few species which thrive better in Great Britain than in New England.

In 1915, the last of the true Lilacs to flower in the Arnold Arboretum was S. Sweginzowii, a new-comer from northwestern China. This is a shrub of compact habit with rather slender dark red branches and twiggy branchlets with dark dull green sharp-pointed leaves and long narrow clusters of delicately fragrant blossoms. The flowers are flesh-colored in bud and nearly white when fully open and the corolla-tube is slender and about half an inch long.

Of true Lilacs some half-dozen other species are in cultivation in the Arnold Arboretum and promise to have their own peculiar sphere of usefulness in gardens. But at present we do not know enough about their garden value, and, since they are scarcely 
obtainable, further mention of them may be omitted.

The Tree Lilacs, of which there are three species all native of northeastern Asia, differ from the true Lilacs in having a short corolla-tube and protruded stamens. They are large shrubs or small trees with large, broad, much-branched clusters of white flowers of unpleasant odor. They blossom when the flowers of the latest of the true Lilacs are fading. The first of these Tree Lilacs to bloom is $S$. amurensis, from the Amur region of northeastern Asia. This is a small bushy tree with dark green leaves and flatspreading and slightly drooping clusters of ivorywhite flowers. The next to open its flowers is $S$. pekinensis, native as its name suggests of northern China, and is a large bush or bushy tree from twentyfive to thirty feet high and as much through the crown. The branches are more or less pendent at the ends and are clothed with lustrous reddish brown bark which separates into thin layers like that of certain Birch trees. The pointed leaves are long and narrow and hang gracefully and are surmounted by half-drooping flower clusters which are flat and unsymmetrical and smaller than those of the other two species of this group. It was introduced into cultivation by Dr. E. Bretschneider who in 1882 sent seeds 
to the Arnold Arboretum, where it flowered for the first time in 1889 .

The last to flower is $S$. japonica and this is the best known of the Tree Lilacs. It is common in the moist woods and forests of central Japan and increasingly so northward and throughout Hokkaido, whence it was introduced into cultivation by Mr. William S. Clark who sent seeds to the Arnold Arboretum in 1876. At its best it is a round-topped tree from thirty to forty feet tall with a clean, stout trunk covered with smooth, lustrous bark like that of a Cherry tree. The leaves are large, thick, and dark green and the flowers are borne in large, erect symmetrical clusters. The wood is very durable in the ground and for this reason is esteemed above that of all other trees by the Ainu people of Hokkaido for making their inaos or wooden wands used for religious and ceremonial purposes. These inaos are looked upon as continual guardians against harm from Nature, disease, and evil spirits.

Apart from the very numerous seedling varieties of the Common Lilac there are a number of very beautiful Lilacs of hybrid origin and in the years to come a great development of this favorite shrub may be looked for along these lines. Hybrids are usually more vigorous in growth than species and often 
vastly more useful as garden plants. Plant-breeding is full of surprises and it is often the case that parents of indifferent or relatively little garden beauty by judicious mating yield offspring of inestimable value. Already this has happened in Lilacdom. The Hungarian S. Josikaea is perhaps the least beautiful of all known Lilacs but crossed with the Chinese $S$. villosa it has given rise to a handsome new race known collectively as $S$. Henryi after the originator, Monsieur L. Henry, a gardener at one time attached to the Jardin des Plantes in Paris. The best known and most beautiful of these hybrids is Lutèce, which is a compact, fast-growing, large shrub with foliage resembling that of $S$. villosa, and large, erect clusters of rose-purple flowers and it is one of the latest of all Lilacs to blossom.

The oldest of Hybrid Lilacs and one of the brightest jewels in the crown of Lilacdom is the Rouen Lilac which appeared in the Botanic Garden at Rouen in 1795. It is a hybrid between the Common Lilac (S. vulgaris) and the Persian (S. persica) but through an error as to its origin it was christened $S$. chinensis -a name at once unfortunate and utterly misleading. In gardens it is also known as $S$. rothomagensis. It is one of the most floriferous of all Lilacs and in its slender branches and narrow leaves and its small 
flowers borne in enormous clusters it resembles its Persian parent while the color of the flowers shows the influence of the Common Lilac. In addition to the type there is a form $(a l b a)$ with nearly white flowers.

Another interesting hybrid, also raised in France, is $S$. hyacinthiflora which is a cross between the Common Lilac ( $S$. vulgaris) and the Chinese $S$. oblata. It is a large and vigorous and shapely plant with good foliage and small clusters of small, semi-double, bluish purple, very fragrant flowers. It is less ornamental than many other Lilacs and as a garden plant it is chiefly valuable on account of its earliness to blossom, a character which it inherits from its Chinese parent. There are other hybrids of value though less well known, but enough has been written here to prove, if it be necessary, that even if the Lilac has entered into its kingdom the frontiers of its dominion have not yet been approached. 


\section{CHAPTER XIII}

\section{NEW HERBACEOUS PLANTS FROM CHINA}

SOME NOVELTIES FOR THE HARDY PERENNIAL GARDEN THAT PROMISE WELL

MONG the wealth of new material which
recent plant exploration work in central
and western China has added to the gardens of North America and Europe there are not lacking herbs of more than usual interest and value. My own specialty is woody plants, but actuated by an ardent love for flowers of all sorts opportunity to send home material of herbaceous plants was never missed. Moreover, the principal object of my second journey to China (1903-05) was to try to introduce a yellow-flowered Poppywort (Meconopsis integrifolia) which was known to grow in the alpine regions of the Chino-Thibetan borderland. Complete success attended the quest but the plant has not taken very kindly to cultivation in Great Britain and it cannot be recommended as a suitable plant for American gardens.

This Poppywort is a biennial and grows from one and a half to three feet tall and has rather 


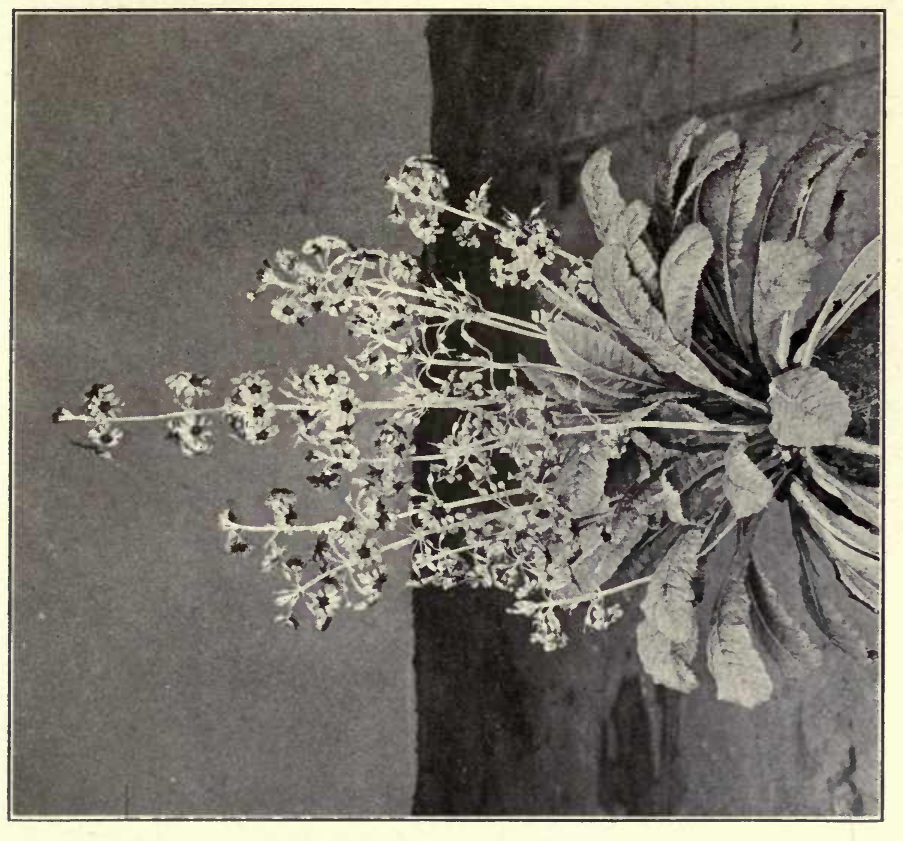

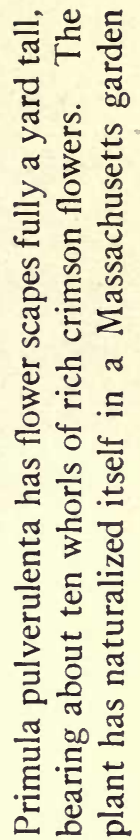

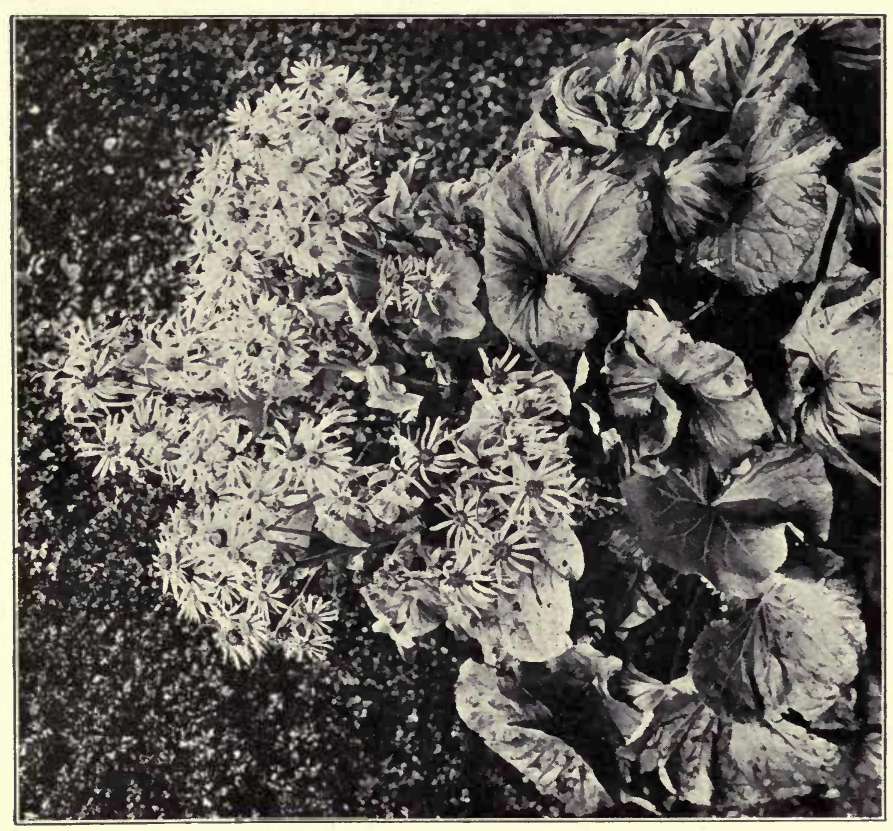

$\stackrel{2}{2}$

용

ษัฐ

造

ஸे 긍

힐

은 덩 힌

을

$\cong$

혼

$\pm$.

$<\frac{\pi}{2}$

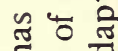

工

E. 造

를

․ㅗㄱ

ป ठ

월 

globular, clear yellow flowers each from six to eight inches in diameter. It is probably the most gorgeously beautiful of all alpine plants, and what joy it would give me could I recommend it to the garden lovers of this country in general. This cannot be done, yet it is probable that in parts of Maine, like Bar Harbor, in Oregon, British Columbia, and other districts enjoying a cool summer climate and an abundant snowfall in winter, this remarkable plant would thrive. I do not know that it has been given a trial in the regions mentioned. But if this Poppywort is not for the ordinary garden there are other handsome and useful herbs from central and western China which are easily cultivated and are deserving of the widest recognition. In this chapter I propose to mention in cursory detail what I consider to be the best of the herbs it has been my good fortune and privilege to introduce to the gardens of western lands. The great majority are vigorousgrowing and very hardy herbaceous perennials and in this connection a few remarks of a general character may be in order.

Hardy herbaceous plants do not at present enjoy the same favor in this country as in Great Britain but each succeeding year appreciation of them increases. Like trees and shrubs, perennial herbs 
give permanence to garden beauty and are essentials in the order and fitness of things. In every garden, large or small, there is place for them, and in this class of herbs there is a great variety of plants of perfect hardiness and of easy culture which will embellish and beautify any and every site, be it the woodland, waterside, open border, or the immediate precincts of the home. In a natural state a majority of these showy and vigorous herbs grow on the margins of woods and thickets, in moist meadows, or by the sides of streams and lakes. In such places the roots are kept cool and abundantly supplied with moisture and in the autumn the crowns are covered with quantities of fallen leaves. These facts are significant and their appreciation of fundamental importance in the successful cultivation of these plants. If one is desirous of growing good vegetables the soil must be rich and must be kept so by frequent dressings of farm-yard manure or some equivalent fertilizer, and this is true in the matter of herbaceous perennials. In addition to a rich soil, ample water supply at the root, and an autumn mulch of leaves and well-rotted manure, frequent division of the root-stock and transplanting are essential to ensure full results in border cultivation of most hardy perennial herbs. Lastly, it may be pointed out that 
this class of plants will withstand low winter temperatures with immunity but summer drought is fatal. They revel in regions where in summer hot, sunny days are followed by cool nights and where precipitation is even and ample.

For the waterside and woodland the Senecio tribe is full of good things. The genus is one of the largest in the vegetable kingdom. It has a world-wide distribution and in China alone is represented by more than a hundred distinct species. The majority of these are weeds pure and simple and of no ornamental value whatsoever. On the contrary, others such as S. clivorum, S. Veitchianus, and S. Wilsonianus are of striking beauty. These three species agree in having bold, reniform-cordate dark green leaves each a foot or more across, on long and stout stalks, but are otherwise quite dissimilar. The first named has a much-branched flattened inflorescence, from one and a half to two feet across and raised well above the luxuriant foliage and bearing masses of Aster-like flowers, each from three to five inches in diameter and of a peculiarly rich golden yellow color in shade unlike that of any other plant in cultivation. Senecio Veitchianus and S. Wilsonianus have erect spikes of flowers from five to six feet or more tall. In the first the spike is simple and tapering and the flowers are clear 
yellow in color. In $S$. Wilsonianus the spike is cylindrical, like an enormously elongated thyrse, and branching at the base, and the flowers are deep yellow. In both of these plants the actual length of the spike clothed with flowers is from two to three feet. Strong clumps of these three Senecios produce in August and September a dozen or more flowering spikes bearing many hundreds of flowers and are extremely attractive.

Quite different from the above but equally charming is $S$. tanguticus which grows from four to five feet tall and has finely cut foliage and pyramidate panicles from eight inches to a foot high of clear yellow flowers. The individual flowers are small and the whole plant suggests a glorified Golden-rod (Solidago). These Senecios may be easily raised from the seeds which are freely produced and the seedlings grow rapidly and soon make strong flowering plants. Senecio tanguticus is apt to make itself too much at home and must be watched or it will usurp the whole waterside or border.

Closely allied to the above-mentioned plants but totally different in appearance is Artemisia lactiflora. This new Wormwood has finely divided, Chrysanthemum-like, aromatic leaves and large feathery panicles of milk-white, fragrant flowers borne on 
stems from three to four feet tall. In central China this plant is a weed of cultivation and when sending it home I little thought that it would so quickly develop into such a charming and useful garden plant. It may be increased easily from seeds or by division of the rootstock.

Few subjects are more popular for pot-forcing for winter work than Astilbe japonica and A. astilboides, both old but indispensable plants. Their recently discovered relatives, $A$. Davidii and $A$. grandis, are not useful for this purpose; but for the moist border and the waterside they possess much higher claims than our old friends. David's Astilbe was the first of the two known and caused quite a sensation when exhibited. The flowers are of a peculiar shade of red, known before only in the Loosestrife (Lythrum Salicaria), and the anthers are blue. The flowering stems are six feet tall with the flowers densely crowded on much-branched panicles having ascending lateral branches and from two to two and a half feet long. Partial shade is best for this plant since in strong sun the flowers bleach. Astilbe grandis is similar in habit and vigor of growth but has pure white flowers larger than those of any other Astilbe, and the lateral branches of the flower panicle spread horizontally. The leaves of both species 
resemble those of $A$. japonica but are much larger and of greater substance. Hybridists in France and Germany have employed these and other species in the breeding of a new and beautiful race of hybrid Astilbes of which $A$. Arendsii is the type, and there are many named varieties on the market. These Astilbes are easily propagated by division of the rootstock and the species may be raised from seeds without difficulty.

Well fitted for planting alongside Astilbes, or on wet humus-clad rocks are Rodgersia aesculifolia, $R$. pinnata, var. alba, and $R$. sambucifolia. These are strong-growing plants with broad thyrsoid panicles, each from a foot to eighteen inches long, of fragrant flowers borne well above the foliage on spikes from three to five feet tall. In $R$. sambucifolia the leaves are truly pinnate but in the others they resemble in form and texture those of the Buckeye (Aesculus). The flowers are of the purest white. Rodgersias are easily raised from seeds but they grow slowly; the rootstock is a stout rhizome and it is best to commence with strong established roots.

The Rhubarbs are well known and their bold foliage and tall flower spikes make them noble objects yet they can scarcely be classed as choice herbs. Very unlike an ordinary Rhubarb, however, 
is the new Rheum Alexandrae. This remarkable plant has neat, ovate-cordate, shining dark green leaves, each a foot or more long, and an erect tower-like inflorescence a yard or more tall, the showy part of which consists of broad, rounded, decurved cowslipyellow bracts overlapping one another like tiles on a house and beneath which, secure from rain, nestle clusters of inconspicuous flowers. This Rhubarb is native of the alpine meadows and moorlands of the Chino-Thibetan borderland where its peculiar and rich-colored inflorescence makes it conspicuous from afar. The plant grows well in any good, rich, moist garden soil and is fond of partial shade and of cow dung. It is easily raised from seeds but requires several years to develop strong-flowering crowns.

The Aconites or Monkshoods are old-fashioned flowers and count among their numbers many good garden plants. One of these is Aconitum Wilsonii which is related to the old $A$. napellus and is a stronggrowing species with stems from six to eight feet tall and flowers in September. The leaves are leathery, dull green, and deeply incised; the flowers iarge and deep blue in color. After the main spike is past axillary branches continue to bear flowers until the advent of sharp frosts. The rootstock is tuberous and the plants require a rich soil and to get estab- 
lished before the best results are obtained. Another good and very distinct Monkshood is A. Hemsleyanum. This is a twining plant growing from eight to twelve feet high, and in a wild state frequents thickets where it rambles over shrubs and festoons them with a wealth of large blossoms in August and September. The flowers vary considerably in color and although most people like the deep blue best others declare the pale blue forms equally beautiful. The rootstock is tuberous and the twining stems, if made into cuttings in late July, root readily. Aconitum Wilsonii is easily raised from seeds but the opposite is true of A. Hemsleyanum.

The Meadow-rues (Thalictrum), although they have beautiful leaves, are not regarded as showy garden plants yet the new $T$. dipterocarpum is one of the loveliest herbs imaginable. It grows from eight to ten feet tall and the flower stems are very much branched and bear relatively large lavender-purple flowers in great quantity. The leaves are broad and much divided and the whole habit and appearance of the plant are most graceful and elegant. It requires a good, well-drained soil, is fond of lime, and revels in sunshine. Another sun-loving herb is Salvia Przewalskii which grows from two to two and a half feet high and has large blue-purple flowers and good foliage. 
(The Iris family is one of the most beautiful of all, and Iris chrysographes and I. Wilsonii are welcome additions. These new-comers are allied to the wellknown $I$. sibirica and have a similar habit and fibrous rootstocks. They grow from two to two and a half feet high, are very free flowering and have narrow, dark green leaves. In $I$. chrysographes the standards are brilliant dark purple-violet and the falls reddishpurple, each with a median stripe and numerous spots of golden yellow near the base. Iris Wilsonii has clear yellow flowers with a copious veining of purple on the lower half of the falls. These two new species delight in a moist loamy soil, are not averse to partial shade, and are well suited for planting by the side of water.

In recent years China has given to gardens in the west many very beautiful kinds of Primroses and among them Primula pulverulenta, P. Cockburniana, and $P$. Veitchii. In habit and in foliage the first named resembles the well-known $P$. japonica but has flower scapes a yard or more tall and each bears nine to eleven whorls of flowers. The individual flowers are a third larger than those of the Japanese Primrose, rich crimson in color and often twenty or more in a single whorl. The flower scapes are clothed with a white farina and it is this peculiarity 
together with its large flowers and taller scapes that makes this new plant so very superior to $P$. japonica and undoubtedly one of the very finest of all hardy Primroses. There is an albino form, known as var. Mrs. R. V. Berkeley, which has cream-white flowers each with a rich orange-colored eye, and is a worthy companion to the crimson-flowered type. In Massachusetts $P$. pulverulenta thrives and is perfectly hardy; in one garden I know, that of General Stephen M. Weld at Dedham, Mass., there are large colonies of this plant naturalized from self-sown seeds. It is a true perennial of vigorous growth, is very floriferous, and remains in flower for a couple of months.

Primula Cockburniana has neat obovate, pale green leaves and bright orange-scarlet flowers, each an inch across, and borne in several whorls on scapes from one to one and a half feet high. The color of the flowers in this Primrose is unique in the family and is one of the rarest colors in the vegetable kingdom, but, unfortunately, the plant is virtually a biennial. Hybridists, however, have secured several crosses between it and $P$. pulverulenta and some of these hybrids have the perennial character of the last named and flowers of the same color as those of $P$. Cockburniana. In stature and habit these hybridsto which the names Unique and Unique Improved 
have been given by the raisers-are intermediate, and there is every possibility of a new race of hardy Primroses, distinguished by their remarkable orangescarlet-colored flowers, being developed from these two species. A shady position, fairly heavy loam, cow dung, and an abundance of water at the roots are the essentials for the successful culture of these Primroses. An ideal spot is the side of a woodland stream free of rank weeds.

The third species ( $P$. Veitchii) is a true perennial, with leaves resembling those of $P$. obconica but with a dense felt of white hairs covering the underside. The flowers are of a pleasing bright rose color and are freely produced in whorls on scapes from one to one and a half feet tall. A hardy P.obconica with non-poisonous leaves sums up $P$. Veitchii. A light loamy soil rich in leaf-mold and a moderately dry situation are necessary for its successful cultivation and under such conditions it will naturalize itself.

Although not hardy except in the warmer parts of this country Corydalis thalictrifolia and C. Wilsonii deserve mention here. The first has leaves rather fleshy in texture in shape resembling those of a Maidenhair Fern, and very numerous erect racemes of large clear yellow flowers. The other is a smaller plant with finely cut leaves, covered with a white 
farina, and erect racemes of deep yellow flowers. If seeds be sown in May in a cool greenhouse and the seedlings potted on they will flower the following winter. Their culture is of the simplest and those on the look-out for pleasing decorative plants, for basket or pot culture in a cool greenhouse, will do well to give $C$. thalictrifolia and $C$. Wilsonii a trial.

Lilies belong in the category of herbaceous perennials and I am tempted to add a word on their behalf. At the commencement of this chapter it is emphatically laid down that a rich soil is necessary to obtain full results in the herbaceous border. Lilies are an exception. To them manure is absolutely inimical and I do so much wish that lovers of these flowers would appreciate this fundamental truth. It is true that some, like Lilium tigrinum and L. Henryi, will withstand abuse in this direction as in others, but there are very few that can. The herbaceous border with its rich soil is not the place for Lilies. They should be planted in association with low-growing shrubs, as stated in Chapter II.

In the Regal Lily (L. regale) it is generally conceded that garden lovers have a "jewel beyond price," but the discoverer is fearful lest its admirers undo it with kindness. Loam, leaf-soil, good drainage, and full exposure to sun and air are the essentials demanded 
by this Lily. Do not give it fertilizer in any form any more than you would give an infant in arms beefsteak. And this is true for Lilies generally in the outdoor garden where they are planted in the hopes of their yielding flowers from year to year. Mulch them with leaves in the fall but do not, if you value your Lilies, feed them with manure. 


\section{CHAPTER XIV}

\section{"HARDY" RHODODENDRONS}

AMERICA'S NEEDS AND THE OPPORTUNITIES TO MEET THEM-WHAT MUST BE DONE TO SHAKE OFF THE SHACKLES OF EUROPE'S MODELS

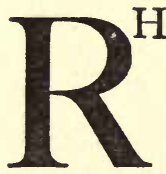

HODODENDRONS are in the forefront among hardy ornamental shrubs and are warm favorites in the gardens of this country and of Europe and more especially those of the British Isles. The evergreen section with its bold foliage and large clusters of handsome flowers numbers within its ranks some of the noblest of all plants found in the north temperate regions. The section with deciduous leaves is not surpassed in wealth of blossom by any class of hardy shrubs. The flowers vary enormously in size in the different species and embrace all shades of every color except blue. In many the flowers are delightfully fragrant and where the climate is congenial the season of flowering is virtually continuous the year round. Small wonder then that the desire to possess them is so very general. No class of shrubs possesses greater attractions, and given certain essential conditions 

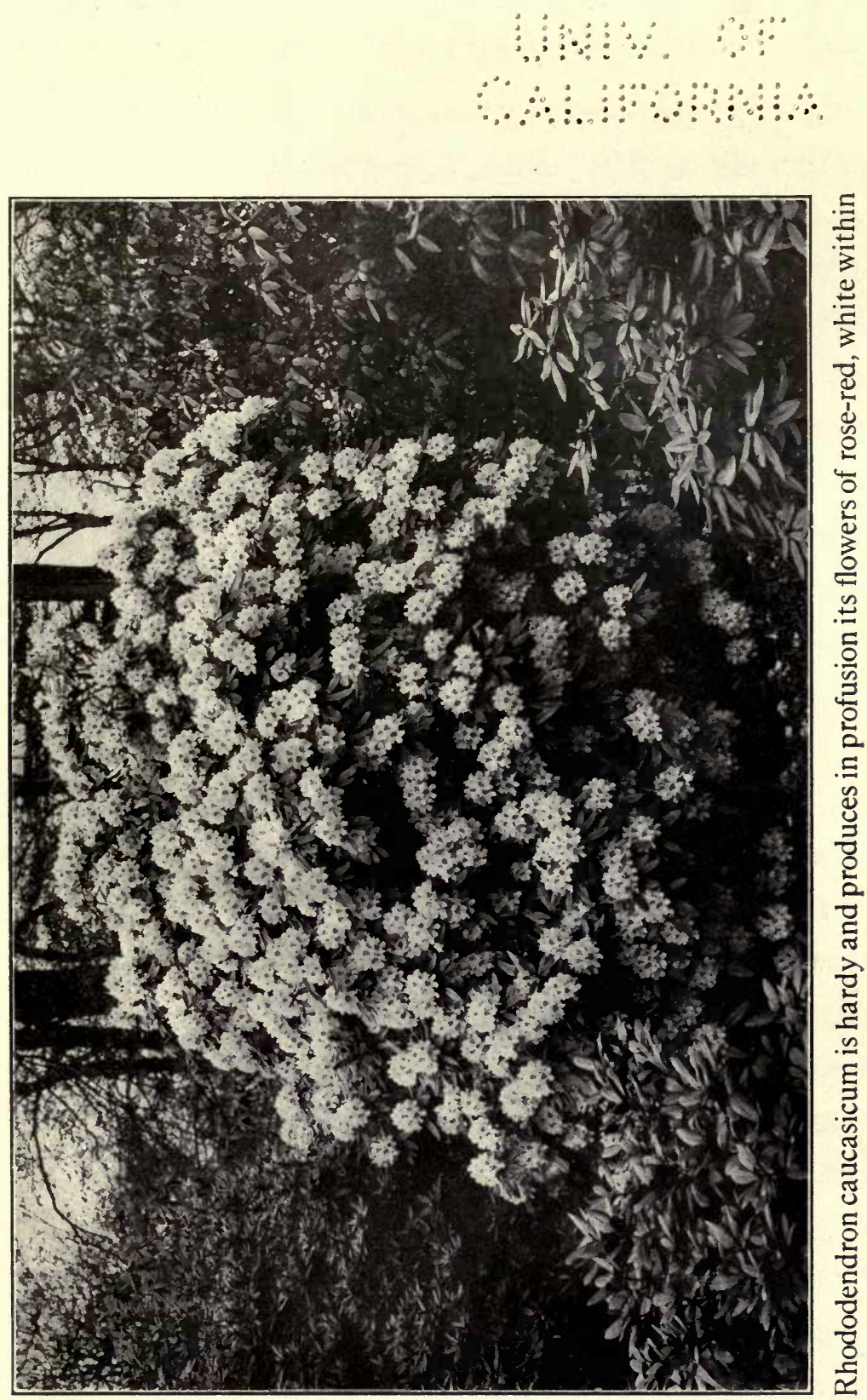


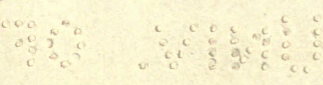

$$
\therefore \text { a }
$$


and provided the varieties planted are perfectly hardy their culture is fairly simple. But in the colder parts of the United States of America the climate is such that only the very toughest of existing varieties survive the summer drought and winter cold, and the need of a more enduring race is patent. In this chapter it is proposed to go fairly exhaustively over the whole field of hardy Rhododendrons and to draw attention not only to a majority of the best sorts American gardens possess, but to delve deeper and point out a possible way toward the attainment of a race more suitable to the climatic conditions that obtain.

The subject has many aspects but it may be opened by remarks on the essential points in the culture of this class of plants in general. Evergreen Rhododendrons are mainly woodland, and in a measure also alpine, plants, and must never be allowed to get dry at the roots. A situation screened from the morning sun and sheltered from cold cutting winds and where the roots may be kept cool is essential to success. The strong sun in March which draws moisture from the leaves when the ground is frozen and the roots perforce incapable of making good the loss is a potent cause of death. This in conjunction with the tender strain in the present-day 
race and the fact that the majority are grafted on the not hardy $R$. ponticum very thoroughly explain the disappointment so generally experienced by American lovers of these plants, and especially those who garden in New England.

If practicable it is best to plant these Rhododendrons in association with trees; for, by so doing, they receive a measure of protection from the sun's direct rays. In thin woods or on the margins of such woods are good sites and if the situation be open and exposed a screen of conifers-Hemlock, White or Red Pine-should be afforded them. If the situation be such that the roots are kept cool by a thorough water-supply, the nature of the soil (always provided it does not contain lime) is of less importance than is often claimed. Where the White and Red Pine, Birch, Chestnut, and White Oak thrive, Rhododendrons will grow. A soil free of lime-sweet, moist, and porous-and fairly rich in leaf-soil is the ideal. A decomposed granitic soil rich in humus is excellent. In the absence of lime, Rhododendrons will grow in good loamy soil; but it should ever be remembered that they are humus-loving plants and require to be mulched with leaves and the soil enriched with leaf-soil or sandy peat. It is usually assumed that peat is necessary in order to grow these plants, but as 
a matter of fact a far greater number of the species find a home on humus-clad rocks and cliffs than in peat swamps.

in regions where the seasons are milder than in New England, these Rhododendrons will thrive in positions more or less fully exposed to the sun; but no matter where they are planted they must never be allowed to suffer from drought. The root system of all Rhododenrons is fibrous and scarcely descends more than a foot below the surface. Obviously a mass of fine hair-like roots near the surface of the ground cannot withstand drought and the need of a mulch of leaves is clearly shown. On account of their fibrous root system, Rhododendrons are easy subjects to transplant provided this be done with a large ball of earth and due attention be given to keeping them properly supplied with water afterward.

The hardy members of the Azalea section are all virtually deciduous and a majority will stand more exposure to sun and drier conditions than will their evergreen relatives, but drought has very evil effects .upon these also. It is advisable to place these Azaleas fairly close together and, as a ground cover, to plant different varieties of Heather (Calluna vulgaris) and hardy Heaths (Erica carnea, E. vagans), 
which are not only pretty in themselves but mask the ground from the sun's rays. Another and highly important item in the culture of all Rhododendrons is to remove all flowers after they have faded to prevent the development of seed pods and to encourage new growths.

A race of Rhododendrons that will thrive in limestone soils is at present a desideratum. There are several Chinese species which grow naturally on such soils, and it is within the bounds of probability that the future may see a race at least indifferent to this mineral. At present, however, those whose gardens are in limestone areas must give up thoughts of growing these plants unless they are prepared to make elaborate preparations and take the risks involved. To those desirous of such experiments it may be pointed out that mounds of prepared soil should be made and not dug-out beds filled with suitable compost since the lime has a very much smaller chance of impregnating a raised site.

For the purpose of this article hardy Rhododendrons may be divided into two groups known popularly as Azalea and Rhododendron. In the first the leaves are deciduous, or nearly so, and rather small; in the second the leaves are persistent and usually of good size. These main groups are pretty clearly 
defined in the minds of all garden lovers, but it is convenient to subdivide them again: the Azaleas into three smaller classes and the Rhododendrons into two.

AZALEA

The three sections of Azalea may be briefly characterized as follows:

a. Rhodora: Flowers from a terminal bud, leafy shoots from separate, axillary buds; corolla almost two-lobed; stamens seven to ten.

b. Pentanthera: Corolla funnel-form, stamens five, otherwise as in Rhodora.

c. Tsutsutsi: Flowers and shoots developed from the same terminal bud.

(a) The first section includes the Rhodora ( $R$. canadense) and $R$. Vaseyi, both good garden plants which thrive best in moist soil and in the neighborhood of water. The Rhodora grows wild from Newfoundland to Pennsylvania and New Jersey, and in the North in May covers large areas of swampy land with a sheet of bloom. This dwarf shrub, with its small rose-purple flowers, is so well-known that further details are unnecessary. Early in May $R$. Vaseyi opens its compact clusters of small pink flowers before its leaves appear. This Azalea is an 
inhabitant of a few of the high valleys of the Blue Ridge Mountains in South Carolina and had been entirely overlooked until some thirty years ago. It is a shrub with slender stems, and of loose, irregular habit, sometimes growing to the height of from fifteen to eighteen feet, although under cultivation it begins to blossom when less than a foot high. It is perfectly hardy and the pure, perfect pink of its flowers is scarcely equalled by that of the flowers of any other plant. There is also a form (album) of this species with white flowers.

(b) Eastern North America is very poor in species of evergreen Rhododendrons but it can claim to be the richest region in the world for the section Pentanthera. Of the thirteen species belonging to this group eight are native of the Atlantic seaboard, and one ( $R$. occidentale) of the western slopes of the Cascade and Sierra Nevada mountains of the West, and another ( $R$. sonomense), with smaller rose-colored fragrant flowers, grows on dry slopes of the mountains near San Francisco, but is not in cultivation. Of the other three, one ( $R$. japonicum) is confined to Japan and Korea, another ( $R$. sinense) to eastern and central China, and the third ( $R$. luteum) to the Caucasus -the region in Asia Minor bordering the Black Sea and known in ancient times as Pontus-and to Galicia 
where only recently it has been discovered. Of the American species of this group five are well established in the Arnold Arboretum and no group of plants perfectly suited to our climate surpasses them in beauty. The first to open their flowers are $R$. canescens and $R$. nudiflorum. Both have fragrant pale rose or pink flowers of various shades which appear before the leaves or just as they begin to unfold. In general appearance these two plants are very similar but one is a southern and the other a northern plant though there are places where they grow together. The plants are twiggy, of medium size, and grow singly or in great masses on treeless hillsides or in open woods. Rhododendron canescens is very abundant in parts of Worcester County, Mass., and $R$. nudiflorum is especially common in the Gulf States from eastern Florida to eastern Texas.

The next to blossom is $R$. calendulaceum, the Yellow Azalea of the Appalachian Mountain slopes which opens its flowers early in June. The color varies from bright yellow to orange or shades of red and the beauty is heightened by contrast with the dark green leaves which are well grown before the flowers open. It is a rather slow-growing but long-lived plant, from eight to ten feet tall, and the beauty of its brilliant-colored flowers is not surpassed by those 
of any other Azalea. The Yellow Azalea is followed by $R$. arborescens, another inhabitant of the glades of the Appalachian Mountains from Pennsylvania to Georgia, which blooms about mid-June. This is a tall shrub, growing from ten to fifteen feet high, with large, pure white, very fragrant flowers, the beauty of which is increased by the bright scarlet color of the long exserted stamen-filaments and styles. The leaves are pale colored and are full grown before the flowers open. The last to flower is $R$. viscosum, the Clammy Azalea or Swamp Honeysuckle, a common inhabitant of swamps near the Atlantic seaboard, which does not open its flowers until July. It is a shrub of medium size with small, very fragrant, pure white blossoms covered with sticky hairs and the leaves are often pale bluish, especially on the lower surface. The plant is valuable for the lateness of its flowers, which continue to open for weeks when those of most shrubs are past.

These five Azaleas are all good garden plants which take kindly to cultivation and thrive in ordinary soil in either open or shady situations.

Of the other American species of this section, seedlings of $R$. austrinum, $R$. candidum, and $R$. flammeum are growing in the Arnold Arboretum, but it is too early to judge of their merits as garden plants. The first has 
pale yellow flowers appearing before the leaves and is native of the valley of the Apalachicola River in western Florida; the second has white or pale pink flowers which appear after the leaves and is native of southern Georgia; the third species ( $R$. flammeum) is common in open woods in parts of central Georgia. The Western $R$. occidentale with its lovely white flowers has not yet been successfully acclimatized in the Arnold Arboretum.

The Chinese $R$. sinense has large, rich yellow flowers and is almost hardy with us; the other east Asiatic species ( $R$. japonicum) is perfectly hardy and its large flame-colored flowers are very handsome. These species grow from four to six feet high and have stiff and relatively thick ascending branches. The remaining species ( $R$. luteum, or incorrectly $R$. flavum), commonly known as Azalea pontica, is not hardy in the Arnold Arboretum. It has been much used in hybridizing as we shall presently see, but it is doubtful if the true species is in cultivation in this country.

As shown above there is a great range of color in the American Azaleas and being perfectly hardy one would naturally expect to find them very generally planted in the gardens of eastern North America. Such, however, is not the case for the simple reason that it is difficult to procure them, for very few Amer- 
ican nurserymen are willing to devote the time and trouble necessary to raise these plants from seeds, the only successful way in which they can be propagated.

In the absence of these plants and in ignorance of their value and beauty, resource is made to the socalled Ghent Azaleas-a race of enchanting hybrids, but short lived, indifferently hardy, and not suited to the climate of New England. As pot plants for forcing purposes it is all very well to import them from Europe by the shipload, but for the embellishment of the outdoor garden in the colder parts of this country they cannot be recommended. Much may be learnt from history in the matter of plants as in that of mankind, and the outlines of the origin of these so-called Ghent Azaleas are instructive. In 1738, Peter Collinson introduced from this country into England, $R$. nudiflorum, $R$. viscosum, and $R$. calendulaceum; in 1793, $R$. luteum was introduced from the region bordering the Black Sea. This Pontus Azalea has fragrant, bright yellow flowers each two inches across and its value as a garden plant was soon recognized. In a few years a great number of hybrids between it and its American relatives were raised in England. The work was soon taken up in Ghent, first by a baker named Mortier and afterward by various nurserymen of whom Van Houtte was the 
first to raise forms having double flowers. But $R$. luteum came from a warm climate and its influence on hybrid offspring has been toward a dislike of low temperatures. In a measure this explains the lack of success experienced by garden lovers of New England with these Ghent Azaleas. It is probable that if seeds of $R$. luteum were obtained from its altitudinal limits in the Caucasus or from Galicia a hardier type would result.

Another class of Rhododendrons much cultivated in Belgium is that known as Mollis Azaleas. This has resulted from the intercrossing of $R$. sinense and $R$. japonicum with various Ghent Azaleas. The class is a very beautiful one but is not more hardy in New England than the pure Ghents.

(c) Under the name Tsutsutsi the Japanese include most of the Azaleas known in Japan, and of the three species of this section which it is necessary to mention here two grow naturally in the Land of the Rising Sun and the other in Korea. The most important is the scarlet-flowered R. Kaempferi which was introduced by Professor Sargent in 1892, and is one of the most valuable shrubs that garders of eastern North America have received from Japan. It is a deciduous and perfectly hardy shrub with slender stems and twiggy branchlets and grows 
from three to eight feet high. The blossoms open about mid-May and the plants are a perfect blaze of color for one to two weeks. Where fully exposed to the sun the flowers bleach, and to enjoy the full beauty of this shrub it should be planted in partial shade. It is good as a specimen bush but it is better when massed. The other Japanese species, $R$. rhombicum, is a shrub growing from four to ten feet high with slender rigid stems and rich red-purple flowers in small clusters. It is perfectly hardy and thrives in the open or in partial shade.

The Korean species ( $R$. poukhanense) is a new introduction and was raised in the Arnold Arboretum from seeds sent by Mr. J. G. Jack from Korea in 1905. In cultivation it is a low, much-branched, very compact round-headed shrub and perfectly hardy. The dark green, oblong, pointed leaves are deciduous and the flowers are rosy mauve or red-violet in color and delightfully fragrant. This new Azalea flowers very freely and promises to be an excellent plant for the open border or for the rockery. A double-flowered form is in cultivation under the name of Azalea yodogawa, but this plant is very inferior to the type species.

There are other well-known and beautiful Azaleas like $R$. amoenum, $R$. obtusum, and $R$. ledifolium - unfor- 
tunately not quite hardy in New England-and rarer species like $R$. Schlippenbachii and $R$. Albrechtii, but we must hasten to deal with our second main division.

\section{RHODODENDRON}

Hardy evergreen Rhododendrons may be divided into two groups characterized by the nature of the undersurface of the leaves. In one the underside of the leaf is more or less densely dotted with small, often brownish, scale-like glands; in the other it is either smooth and green, or more or less hairy (often densely felted) or clothed with a pale or dun-colored crustaceous covering.

(a) The group with dotted leaves is a very extensive one and a great number of species grow on the mountains of western China and on the Himalayas and three (R. carolinianum, $R$. minus, and $R$. lapponicum) are native of eastern North America. All have small or comparatively small leaves but only a very limited number have proved to be hardy and amenable to cultivation in this country. Many of them may be rooted from cuttings, but it has been found difficult to hybridize them with members of other groups. As a garden plant for this country, $R$. carolinianum is by far the best species of this group and is one of the very finest of all broad-leaved Evergreens hardy in 
Massachusetts. It is a shrub of compact habit from four to six feet tall and as much in diameter, with handsome dark green leaves and is very floriferous. The flowers are pale to deep pink and are borne in clusters and open and fade before the young branches begin to grow and therefore are not hidden by them. The species is native of high altitudes in the southern Appalachian region and was formerly confused with $R$. minus, which grows in the same region but at a lower level, under the collective name of $R$. punctatum. Rhododendron minus is an old denizen of gardens and has smaller leaves and flowers and a more open habit than $R$. carolinianum and the flower clusters are much hidden by the young branches which rise high above them. The third native species ( $R$. lapponicum) is an alpine plant which also grows wild in Europe and has proved a difficult subject under cultivation.

The two dwarf Rhododendrons ( $R$. ferrugineum and $R$. hirsutum), natives of the mountains of central Europe, are unsatisfactory in New England but three hybrids between them and the American $R$. minus and $R$. carolinianum are valuable garden plants in this climate. One of these hybrids ( $R$. myrtifolium) is between $R$. hirsutum and $R$. carolinianum and is a very compact round-topped shrub, from two to four feet in height and as much through, with neat foliage and 
small, pretty pink flowers. Another ( $R$. laetevirens), known in gardens as $R$. Wilsonii, is a cross between $R$. ferrugineum and $R$. minus and is a shrub of open, spreading habit and forms low, wide masses. The foliage is light green and handsome but the flowers are small and of an unattractive rose color and the value of the plant is in its ability to cover either sunny or shady banks and for this it is admirably adapted. The third hybrid is $R$. arbutifolium and is probably also a cross between $R$. ferrugineum and $R$. minus. It is not so good a garden plant as $R$. laetevirens.

From the cold regions of Mandshuria and Korea came $R$. dahuricum and $R$. mucronulatum, which though they belong to dotted-leaved group have deciduous leaves. These grow from four to eight feet high and are sparsely branched. In the first named the flowers are deep rose-purple and pink, and rose-colored in $R$. mucronulatum. They are the earliest of this class to open their flowers and in consequence these are often spoilt by late frosts in the spring. Other early-flowering Rhododendrons are $R$. praecox and its variety Early Gem, which are the result of crossing the Himalayan $R$. ciliatum and $R$. dahuricum. Both are evergreen bushes, much branched and compact in habit and have pale to deep pink flowers. In favorable seasons 
when the flowers escape late frosts these plants are very beautiful in spring, but unfortunately this rarely happens.

Valuable for the rockery and partial to sunshine are $R$. racemosum, $R$. flavidum, and $R$. intricatum, three new-comers from China. They are twiggy plants growing from four to six feet high and may be rooted from cuttings. The first named was introduced into Paris about 1890 , and has pure pink to rose-colored flowers. The other two were introduced into England by myself in 1904, and one, as its name suggests, has pale yellow blossoms while those of $R$. intricatum are pale violet. These species are very floriferous alpine plants with small leaves and flowers and of neat and charming habit.

The only other species of this group that need be mentioned is $R$. micranthum, also from China, which has clusters of minute Ledum-like white flowers and small leaves. It is a hardy plant of twiggy growth well suited for massing and grows from four to six feet tall.

(b) We now come to the last group, the most valuable and desirable of all, and the one with which most people associate the name Rhododendron. As met with in gardens and in nurseries this group is mainly of hybrid origin and I may preface what follows by an 
enumeration of the best varieties which the experience of the Arnold Arboretum has found most adaptable to this climate. With red flowers-Atrosanguineum (very early), Charles Dickens, H. W. Sargent (late); with reddish flowers-Caractacus; with rosecolored flowers-Roseum elegans, Lady Armstrong; with pink flowers-Mrs. Charles Sargent, Henrietta Sargent; with dark purple flowers-Purpureum grandiflorum, Purpureum elegans; with light purple flowers -Everestianum; with white or nearly white flowers, Album elegans, Album grandiflorum, Catawbiense album (very early). A few more are mentioned later on in the text and one or two others, for example, the white-flowered Madame Carvalho, are promising.

It will be seen that the number is very small, and also it must be pointed out that in the Arnold Arboretum these plants occupy a very favorable position at the base of a steep slope clothed with Hemlock and therefore much protected. Had this chapter been written two or three years ago one might have included other varieties such as Mrs. H. H. Hunnewell, King of the Purples, and Delicatissimum, but longer experience has proved them less hardy than was generally supposed.

The mild winter of $1914-15$ will long be remembered 
by all lovers of evergreen Rhododendrons who endeavor to grow these plants out of doors in New England. The effects in general were disastrous though fortunately there were exceptions. In some gardens these Rhododendrons came through exceptionally well, in others the mortality was greater than ever before. In the Arnold Arboretum varieties for twenty years considered "ironclad" were killed outright. No general statement can possibly explain these inconsistencies, but the fact outstanding is that for New England a tougher and more adaptable race of evergreen Rhododendrons is absolutely necessary if they are to occupy in gardens the permanent place their beauty merits. Continuing to import plants bred and nurtured in alien lands where milder climates prevail will not solve the difficulty. Neither will digging plants from the mountains of Pennsylvania, shipping them in carload lots to furnish the estate and coaxing them in every possible way. This despoiling of the countryside is most reprehensible. It is vandalism; it is destructive and absolutely opposed to the true spirit of gardening which essays to be constructive. None of the easy and apparent short cuts will attain the object. The problem has to be studied from a very opposite viewpoint and attacked accordingly. True horticulturists should 
welcome it since it affords much scope and opportunity to prove their worth.

\section{OUR VITAL NEED}

Let us dig casually into the subject and look the facts squarely in the face, and having realized our situation perhaps some one will seize the vast opportunity that awaits. What American gardens need is a race of evergreen Rhododendrons with good foliage, and large and bright-colored flowers, that is perfectly hardy. It is admitted that the few kinds enumerated earlier have endured the summer drought, the winter cold, and the March sun of New England more or less satisfactorily for a number of years but they are still uncertain and owners breathe freely each May when they find their plants alive and healthy. In Massachusetts large sums of money have been spent on these plants but the results on the whole are discouraging and some who have given much in time, labor, and money in the attempt to make this class of Rhododendrons grow successfully are losing or have lost hope. Such are the facts of the presentday situation in New England and it is pertinent to ask: Is there a remedy or a way out of the difficulty?

I make bold to say that there is, but it entails beginning again. It means commencing here in New 
England and elsewhere in this country, and breeding a race suited to the climatic conditions which obtain; it means abandoning the old and lazy policy of relying upon other lands to supply our needs in this respect; it means that we must do here what Europe has done, namely, work out our own salvation. We start later than they across the Atlantic but we start with great advantages including those which have accrued from the labors of the past. A little of that concentrated effort and skill which have produced that most typical of American floral products-the Perpetual-flowering Carnation-would yield us our desire in the matter of a race of hardy broad-leaved evergreen Rhododendrons.

The present-day race of evergreen Rhododendrons is essentially an English product and to better understand the subject let us briefly investigate its early history. No Rhododendron is native of the British Isles and the first of the evergreen section to be introduced was $R$. maximum, indigenous in eastern North America, which flowered for the first time in London in 1756. A few years later (1763) $R$. ponticum was introduced and was followed in 1803 by $R$. caucasicum. The American $R$. catawbiense was introduced by John Fraser about 1809, and was common in gardens in 1838. Here are the beginnings of the Rhodo- 
dendron cult in England. Of these four species two only ( $R$. ponticum and $R$. catawbiense) have played a major part.

As a breeder $R$. ponticum has been the greatest asset and although its color is not good it has proved extraordinarily adaptable in Great Britain and Ireland. This species grows wild in southern Spain and in Asia Minor, in Syria, and the warmer parts of the Caucasus. These regions enjoy a much warmer climate than does New England and from our viewpoint it is a tender species and unsuitable as a breeder. Also, for the same reason, it ought not to be used as a stock for grafting, yet, unfortunately, it is the stock so employed. An appreciation of these facts explains in a large measure the doubtful hardiness and uncertainty of the present-day race of Rhododendrons since the blood of this tender species enters largely into the majority of the varieties.

In the matter of hardiness the American $R$. catawbiense has been the greatest of all gifts in the realm of Rhododendron, and the hardiness of our presentday race depends almost solely upon the dominant influence of the blood of this species.

Rhododendron caucasicum is native of the higher Caucasus peaks and should be of much value to us since it is quite hardy in New England. Unfortu- 
nately it has been very little used by hybridists but such offspring as Boule de Niège, Coriaceum, Jacksonii, and Mont Blanc are very satisfactory plants in the Arnold Arboretum.

Our native $R$. maximum, though the first species introduced into cultivation, has played a very unimportant part in the evolution of present-day Rhododendrons. In a manner it has been disappointing, yet it is questionable whether it has had a fair chance. To us its hardiness and late flowering are qualities of vast import.

The first authentic hybrid is considered to have arisen accidentally about 1820 , between $R$. ponticum and $R$. nudiflorum (an American species of the Azalea section), and is still in cultivation under the names of $R$. odoratum and $R$. azaleoides. About the same time. $R$. catawbiense was crossed with $R$. ponticum but the results were unimportant. Other early hybrids were Hybrid Maximum ( $R$. ponticum x $R$. maximum) and Caucasicum album ( $R$. ponticum album $\mathrm{x} R$. caucasicum).

The earliest-introduced species were lacking in color and their hybrid offspring had the same defect. In 1811 , the Himalayan $R$. arboreum with intense red flowers was introduced into England and this marked an epoch in the cult of the Rhododendron. The first 
really important hybrid resulted from crossing $R$. arboreum and $R$. catawbiense in 1826, and was named $R$. altaclarense, and the present-day race may be said to date from that period. But this magnificent Himalayan species is less hardy than $R$. ponticum and is quite unsuited to the climate of New England. Furthermore, it flowers very early, which is another drawback.

Until about 1850, these were the only species of this section of Rhododendron in cultivation and such hybrids as were raised resulted from their interbreeding and that of their offspring. In 1848, R. Griffithianum was introduced to England from the Sikkim Himalayas, and in 1855, R. Fortunei from eastern China. These two species have given birth to many wonderful hybrids, but, alas, all of them too tender for this climate. Other Himalayan species have played a part in the evolution of the wonderful variety of Rhododendrons eminently suited to the moist and mild climate of the British Isles, but their influence has not made for a race of value to eastern North America.

In a general way it may be said that Rhododendron breeders in England until late in the nineteenth century kept away from the species as much as possible and intermingled the blood of the best of the 
hybrids. Some, like the famous house of Waterer, never lost sight of the invaluable quality of hardiness possessed by $R$. catawbiense and it is these men that we must thank for such blessings as we possess among the present-day race. Latterly the species have been more favored for breeding in England; and in Cornwall, since the advent of a host of new ones from China, Rhododendrons may be seen in bloom in every month of the year.

Such are the bald outlines of the Rhododendron cult in England, and for our purpose there is no necessity to go more deeply into the matter. It lays before us the origin of the present-day race and points clearly to the cause of its lack of hardiness in the severe climate of New England.

Let us now take stock of the field in general. The regions where Rhododendrons hardy in Great Britain grow naturally have been fairly well explored. Not all the species have been brought into cultivation, but to-day we are in a position to take a comprehensive view of the whole situation; and, insofar as the colder parts of this country are concerned, certain fundamental facts may be deduced. And it is on these bedrock facts that we must rely and build if we are to obtain the object desired.

Rhododendrons are found wild in the moist tem- 
perate parts of the Northern Hemisphere and a certain group extends through the tropics of Malaysia to northern Australia, but for the purpose of this article this group may be eliminated for reasons which are obvious. Evergreen Rhododendrons are essentially mountain plants where a majority grow naturally in woods and not a few are purely alpine. No species has been found in Africa nor in South America. Of the large-leaved section only four species ( $R$. ponticum, $R$. caucasicum, $R$. Smirnowii, and $R$. Ungernii) are found in Europe and Asia Minor including the Caucasus. In North America only three species ( $R$. maximum, $R$. catawbiense, and $R$. californicum) occur. Japan has but three ( $R$. Metternichii, $R$. brachycarpum, and $R$. chrysanthum). The great concentration is in western China and the Himalayas where more than one hundred species have been discovered. It had been expected that the floral wealth of central and western China would add a few species to the list of large-leaved Rhododendrons hardy in New England even though the Himalayan region had failed us, but, unfortunately, these hopes have not been realized. Admitting that this is disappointing nothing is gained by dwelling upon it despondently and some of these Chinese species will yet stand us in good stead. 
Of the introduced species of Rhododendron with large evergreen leaves five only are hardy in the Arnold Arboretum. These are the native $R$. maximum and $R$. catawbiense, $R$. Smirnowii and $R$. caucasicum from the Caucasus, and $R$. brachycarpum from northern Japan and northern Korea. One other species ( $R$. chrysanthum) with pale yellow flowers ought to be hardy here for it grows in the cold regions of northeastern Asia and on the tops of high mountains in Hokkaido, Japan, where I have gathered it in flower on the last days of July with unmelted snow in patches lying around. It is, however, an alpine plant and though introduced to cultivation about 1800, and again about 1850, has never been a successful garden plant. This being the case it is on the above-named five species that all our hopes are centred and it is in the commingling of their blood that we must look for the foundations of a race of large-leaved evergreen Rhododendrons capable of withstanding the rigors and vagaries of this climate. And we are really fortunate to possess five species which, as we have seen, is more than was known when the work began in England.

Theoretically, if the parents are hardy the offspring will be equally so, but in plant-breeding this does not always work out in practice. For example, 
there are hybrid offspring of $R$. maximum and $R$. catawbiense such as $R$. wellesleyanum, which has proved anything but hardy. Again, in the Arnold Arboretum many plants of Delicatissimum, a hybrid between these two American species and for the last thirty years considered one of the hardiest and most desirable of the Rhododendrons which have been planted in New England, died from the effects of the winter of 1914-15. Thus caution is necessary; but, in cross-breeding among the five species of proven hardiness, there is every possibility of evolving a very tough hybrid race. But to ensure success it should be done in this country as far north as possible, so that the progeny may become inured to the climate from their babyhood up.

Except in time and place such work as is advocated here is not altogether de novo. I do not know whether $R$. brachycarpum has been experimented with; but the others have, and with encouraging results, especially $R$. Smirnowii, a hybrid of which is giving much satisfaction in the Arnold Arboretum. The Lace-wing Fly is a bad pest on Rhododendrons in which the undersurface of the leaf is smooth and green, but it cannot attack $R$. Smirnowii the undersurface of whose leaves is clothed with a felt of woolly hairs. This species promises, therefore, to be of value in 
other ways than mere hardiness. In Germany, where the climate is more severe than in Great Britain, a certain amount of Rhododendron breeding has in recent years been done and two hybrids-Viola, with white flowers, and Albert, with pale pink flowers -promise to succeed with us. But it will not solve 'our problem if such hybrids are raised and nurtured in lands where a milder climate obtains. Furnish the garden with material grown in a region as cold as or colder than that where the garden is situated should be a fundamental rule among garden lovers. If some of us spend a few years in Florida and then winter in Massachusetts we shall feel the cold more than will those who have never left the state and very much more so than others inured to the climate of Labrador. It is the same with plants.

The results obtained by the inter-crossing of the five hardy species will in all probability be lacking in color, and pale washy pink and pink colors predominate, for since none of the parents has highly colored flowers we must not expect them in the progeny. In the historical note it is shown that on this account Rhododendron breeding in England languished for years-until the advent of species from the Himalayas with deep rose, scarlet, and crimson flowers. The intense colors in the hybrid Rhododendrons 
of to-day came from this Himalayan element and especially from $R$. arboreum. Again, our position here is more fortunate than that of English pioneers since the fruit of their labor is at our disposal. To give color to our new race we can employ the redflowered Atrosanguineum, Charles Dickens, and $\mathrm{H}$. W. Sargent which are among the hardiest of all hybrids.

Furthermore, the great wealth of material from western China is likely to be of much service, for though it cannot withstand New England winters it is much hardier than the Himalayan element and there are species like $R$. calophytum, $R$. oreodoxa, $R$. Fargesii, $R$. orbiculare, and $R$. strigillosum with flowers of rich and beautiful colors. These and very many others are thriving and flowering in England where hybrids between them are being raised, and by the time our hardy home-bred race is ready, ample new material to assist its development will be available.

Gardens are destined to become in this country just as popular and as necessary a part of the home as they are on the other side of the Atlantic and whosoever works for their advancement and embellishment will not labor in vain. On the lines here briefly sketched there is every reasonable possibility of breeding a race of broad-leaved evergreen Rhododen- 
drons capable of withstanding the vagaries of the New England climate and in no respect inferior to the present race of hybrids whose only fault here is its uncertain hardiness. I have no doubt but that sooner or later some one, amateur or professional, will take up the task and succeed and the monument erected will be more enduring than any of bronze or stone for it will have its foundation in the hearts of all who love their country and their home. 



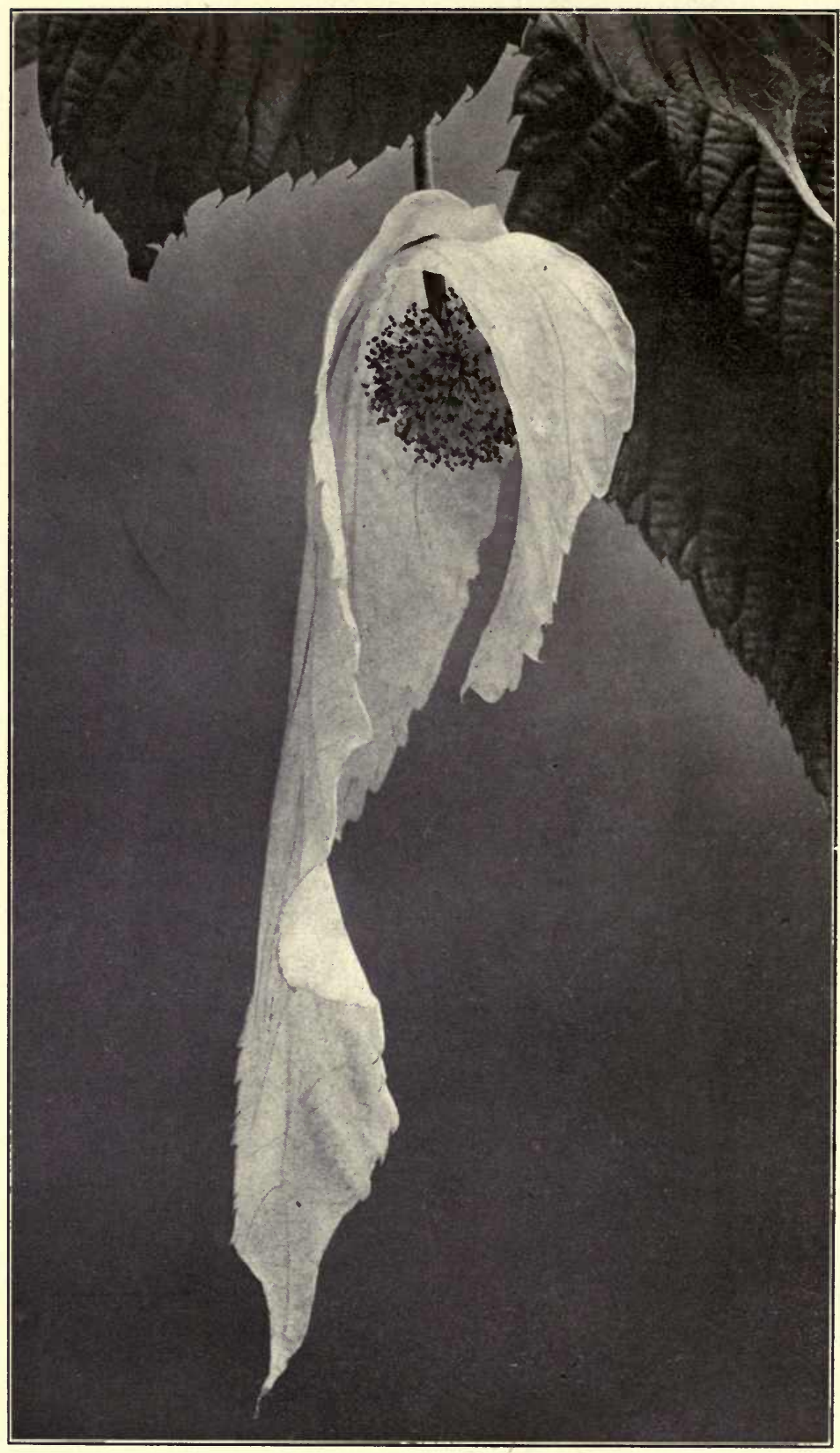

Davidia involucrata, appropriately called the Dove Tree, is indeed remarkable. The larger bract is about as large as a man's hand, becoming pure white as the flowers mature. In China the tree grows to a height of fifty feet 


\section{CHAPTER XV \\ THE STORY OF THE DAVIDIA}

How many garden lovers ever pause to think of the means whereby their gardens became endowed with multifarious variety from distant lands and climes; of the time and money expended in the quest, and of the toll paid in buman energy and life? Could the denizens of our gardens give speech their story would be more engrossing and more romantic tban that told or conceived by authors of the "best sellers." All wbo love a tree give beed for a little wbile and learn bow gardens came into possession of one of the most beautiful and most remarkable of all trees.

7 HE object of the journey is to collect a quantity of seeds of a plant the name of

1 which is known to us. This is the object -do not dissipate time, energy, or money on anything else. In furtherance of this you will first endeavor to visit Dr. A. Henry at Szemao, Yunnan, and obtain from him precise data as to the habitat of this particular plant and information on the flora of central China in general."

So read my instructions from Messrs. Veitch. A three years' agreement was signed on March 27, 1899, and on April 11th I sailed from Liverpool on the Cunard ship Pavonia en route for China via 
the United States of America. Twelve days afterward I landed in Boston, Mass., and on the afternoon of the same day made my first acquaintance with the Arnold Arboretum. My stay in Boston was limited to five days and nearly the whole time was devoted to looking over the Arnold Arboretum collections and I departed enriched in knowledge and with much sound advice on matters relating to the collecting and packing of seeds and plants from Professor Sargent and from the late Mr. Jackson Dawson.

My trip across the continent was delightful; everything was new, strange, and interesting, and the hours of daylight were not long enough to drink my fill from the Pullman windows. When crossing Texas a talkative brakesman told me hair-raising stories of the exploits of the notorious James brothers and so impressive was his language that a thrill goes through me now as I recall it. On May 6th I sailed from San Francisco and on June 3d safely reached Hongkong where I had letters to friends.

The holiday part of my journey was now over. My immediate destination was the Chinese city of Szemao, situated in the southwest corner of Yunnan near the frontier of northern Burmah and my route lay through French Tonking to the Chinese border 
and then across the large province of Yunnan. Hongkong was suffering from its usual visitation of bubonic plague and no Chinese from that colony was allowed to enter Tonking so I was denied the services of an English-speaking Chinese servant which was a great loss. Thanks to the help of my friends, whose efforts to assist in every possible way were unbounded, my arrangements-which included a passport (necessitating a trip to Canton), a supply of provisions, and a traveling outfit-were completed with celerity. I left Hongkong in a steamer on the afternoon of June 14th for the port of Haiphong where I arrived on the 19th idem, and, leaving the same evening, reached Hanoi, the capital of Tonking the following morning. I could speak no French and in consequence had difficulty on landing, but ultimately I reached a hotel and stumbled on a Frenchman who spoke a little English.

For some years past, a railway, built by the French, has connected Hanoi with Yunnan Fu the capital of the province of that name, but in 1899 the survey only was in progress and travelers had to ascend the Red River in small steamers to the frontier town of Laokai, thence by native boats to Manhao and from there journey overland by mules or sedan chairs. The Chinese were strongly 
opposed to the idea of a railway in Yunnan and ugly rumors of impending trouble were abroad.

At Hanoi I had to wait four days for a steamer and leaving at ten A. M. on June 24th I found on board a young Frenchman newly appointed to the Chinese Imperial Maritime Customs and bound for Mengtsze to take up his post. This gentleman spoke English and we made an arrangement to travel in company. At Yenbay, which was reached on the evening of the 25th idem, we had to transfer to a smaller steamer of lesser draught and here a report reached us that an attack on foreigners had occurred at Menstsze and that the Custom House and French Consulate had been destroyed by fire. My newly-found companion became very pessimistic and vowed that we should never reach our destination.

On the afternoon of the 29th idem Laokai was reached and the news of the Mengtsze outrage confirmed in detail. Across a small tributary stream from Laokai is the Chinese town of Hokou where a station of the Chinese Imperial Maritime Customs is maintained. The officer in charge gave us what information he had and read a telegram from the Commissioner of Customs at Mengtsze warning intending travelers that the road was unsafe.

At Laokai a small hotel, styled "Hotel du Com- 
merce," was nearly finished building and I had the honor of being its first guest. The proprietor, Monsieur Fleury, was French but his wife was of English birth, and if ever these lines should reach them, may they assure them that even in these after years I am not unmindful of the courtesy and kindness which did so much toward making life tolerable during my enforced stay.

On the 29th idem I received a note from the French officer commanding the district warning me against proceeding on my journey and in the afternoon news arrived of the murder of four men who had left a few days before for Mengtsze. The outlook was decidedly unpromising but I did not then realize how many dreary days of waiting were ahead of me.

What Laokai is like to-day I do not know but in those days it was a very small village. It is situated on the left bank of the Red River and separated from Chinese territory by a small tributary stream and is backed by low jungle and tree-clad hills with swamps near by. Across the Red River on the right bank was a large military encampment including barracks where were quartered a battalion of the Foreign Legion and several regiments of Annamese troops officered of course by Frenchmen. Laokai is within the tropics and although some hundreds of miles 
from the sea is only a few feet above sea-level and being shut in by jungle-clad mountains the climate is very unhealthy. During my sojourn there bugles announced nearly every morning and evening that one or several soldiers were being laid in their last resting-place. The tiny steamer which left for downstream every Sunday morning was always laden with sick or convalescing soldiers and officers. The heat during the greater part of the day was intense and I could go walking for a few hours only after sunrise and for an hour or so in the evening. It was the rainy season and nearly every day rain fell in tropical fury.

My diary shows that at first although disappointed I settled down to make the best of things and amused myself investigating the flora of the immediate neighborhood of Laokai. As my stay lengthened into weeks my hopes of continuing my journey sank lower and lower and I went so far as to write to both Dr. Henry and my employers advising them that I should have to abandon the effort when, quite unexpectedly, I managed to move onward. Reviewing the affair after a lapse of seventeen years I rather marvel that I did not abandon the venture. Certain it is that my enforced sojourn and inactivity at Laokai were the most discouraging, the most trying, and the most unpleasant to endure of any experiences during 
my eleven years' travel in China. The military authorities were suspicious of me from the commencement, and toward the end it reached my ears that I was regarded as a spy and a captain in the English army, disguised. As a broad hint to quit I received an enlistment notice! Those were the days of the "Dreyfus retrial" and of the "Fashoda incident" and before the "Entente cordiale"--days when a native of "perfidious Albion" was the opposite of a welcome guest in a French colony where military rule was dominant.

During the first few days of exile further details of the Mengtsze outrage reached Laokai and of course rumor enlarged upon the whole situation. A party of Frenchmen surveying for the railway came in from Yunnan, talked of serious trouble, and departed for down river. On the 19 th of July the Commandante sent a note informing me that the route to Mengtsze was then considered safe and this cheered me greatly. I began enquiries for a servant since it was impossible to travel alone, but the news of the riot had done its work and no one could be tempted. This state of affairs lasted for a month. On the 18th of August the following letter was brought to me:

"My Dear Sir,

Before I have wish to do a interpreter with you, because I am very sick cannot to going, at now I 
have a friend he have learned him English for two years at Hongkong, if you wish to get a interpreter he can do.

\section{"Your small servant}

"Limay."

Who Limay was I had not the slightest idea but was grateful to him nevertheless. The bearer of the note was himself the applicant. He was a Chinese of very unprepossessing appearance who smoked opium freely and had been discharged from the Telegraph service for incompetency, but he spoke a little English. I engaged him on the spot, for a chance to reach Dr. Henry presented itself. Not being anxious to do more work than he could help my "interpreter" rounded up an Annamese who could cook and I engaged him, too. On August 23d we left in a native boat for Manhao. The river was in flood. The journey up the Red River due to its flooded condition was slow and not without excitement. Three days out I was overtaken by Monsieur Marty who owned the line of river steamers between Hanoi and Laokai and another line plying to Hongkong where he resided. Monsieur Marty was anxious for company and induced me to travel in his boat. To other accomplishments he added those of a good cook and I was really most fortunate in joining him more 
especially as my own boat in crossing a dangerous rapid had lost masts and sail and was so nearly swamped that I had to transfer everything to my companion's boat. On September 1st we arrived at Manhao and three days later with no untoward event reached Mengtsze.

The Custom House and the French Consulate which adjoined were situated nearly half a mile from the city of Mengtsze. The attack had taken place after midnight; the Consulate was little damaged but the house of the Commissioner of Customs was completely gutted by fire and its contents entirely destroyed. The Commissioner, an American, Mr. W. F. Spinney, with his wife and members of his staff, escaped in their night clothes and though pursued by a howling mob fortunately found, after some difficulty, safe lodgment within the city. One or two servants were burnt to death. The officials made some effort to capture and punish the ringleaders and on my arrival at the entrance to the ruined Custom House, I saw suspended from the branches of a tree, wooden cages containing the heads of five of the rioters. Later I met a posse of soldiers bringing in another gruesome looking head.

His own troubles and difficulties notwithstanding, Mr. Spinney lent me ready assistance and engaged 
mules to take me to Szemao, seventeen days' journey distant. My caravan of fifteen or sixteen mules and several muleteers was imposing and included not only my own belongings, but several cases of silver for Chinese officials at Szemao and a number of cases of stores for the Customs staff. I left on the morning of September 8th, and, being unable to speak any Chinese, traveled very much as a parcel and enjoyed the trip. I received en route a couple of letters of welcome from Dr. Henry and, when two days from my destination, a note from him informing me that a gang of highway robbers had been plying their nefarious calling between the cities of Puerh and Szemao but that the ringleaders had been captured and executed. The officials at Puerh sent ten soldiers as a guard and a few miles beyond that city ten soldiers sent from Szemao joined us, and with these twenty picturesquely clad but grotesquely armed soldiers our caravan looked like a small punitive expedition.

My last night before reaching Szemao was on a Saturday and about nine o'clock, after all had retired, a barking of dogs and some shouting aroused excitement and my soldier guard began to prepare for an attack when the sound of an English voice sent a thrill of joy through me. The door was quickly thrown 
open and I rushed to greet two men, Messrs. Carey and Williams, who with rare forethought of my loneliness had ridden from Szemao to bid me welcome.

The next day we rode quietly into Szemao and I took up quarters in a house engaged for me next door to the Custom House. Dr. Henry was away botanizing when I arrived but returned early in the evening and our meeting was hearty and cordial. During the next few days this gentleman laid bare for my benefit his vast store of knowledge of the flora of China and from his notebooks furnished me with exact information as to the locality of the Davidia in particular and many other plants in general.

My stay at Szemao was profitable and as pleasant as hospitable friends could possibly make it, but was cut short by Dr. Henry receiving orders to repair to Mengtsze and relieve Mr. Spinney. I returned with him and leaving Szemao on October 16th safely reached Mengtsze on the evening of November $2 \mathrm{~d}$. The country was in a very disturbed state and opposition to the French railway most marked. Being in blissful ignorance, all murmurings and grumblings left me unaffected, but my companion-fully conversant with the language-endured some anxiety.

I left Mengtsze on November 13th well primed with valuable information from Dr. Henry and 
some useful practical knowledge derived from my own experiences. Laokai was reached about midnight on the 16th idem, and after a few days' stay I departed for Hongkong where I arrived on the afternoon of November 26th.

During my journeys in Yunnan I collected a number of interesting plants and among them Jasminum primulinum, which has achieved widespread popularity in Europe and in this country. From Hongkong I despatched my collections to England and in due time left for Ichang situated on the Yangtsze River in the very heart of China.

Ichang, where I arrived on February 24, 1900, was to be my headquarters for two years so I made plans accordingly, I purchased a native boat of good size in which to live and to serve as a base of supplies, and engaged some countrymen to assist me in collecting. The all-important arrangements completed, a series of short prospecting trips up country from Ichang were undertaken for the purpose of getting some acquaintance with the flora and for testing and training my men. By the middle of April everything was ready to start in quest of the Davidia. On a half page of a notebook Dr. Henry had sketched a tract of country about the size of New York State and had marked the spot where he had found growing 
a single tree of the Davidia, the only example he had discovered in a trip which extended over six months and the only one he had ever seen. The place was among high mountains in the sparsely populated region bordering the provinces of Hupeh and Szechuan and south of the mighty Yangtsze River. This locality was my destination and this solitary tree my sole objective.

On the morning of April 15th I left Ichang, in my boat, to ascend the Yangtsze as far as the district city of Patung where I arrived on the 21st idem. The journey was exciting, for the rapids which are very numerous were at that season difficult to negotiate. Twice we ran on rocks and had to repair damage. At the worst rapid the boat all but capsized and there were other and numerous incidents which space will not allow me to mention in detail. At Patung the head official did his best to frighten my men and begged me to abandon the enterprise. Finally, his efforts proving of no effect, he promised an escort of six soldiers and washed his hands, as it were, of the business. The man was in earnest and genuinely afraid for my safety. Some two years before there had been much trouble in this region. Rioting between anti-Christian and Christian villagers had taken place; hundreds of lives had 
been lost and whole villages burnt to the ground, and a Roman Catholic priest-Père Victorin-brutally murdered and his corpse barbarously mutilated. A feeling of bitterness and hate still rankled and there was grave danger of some untoward incident causing the smouldering anger to blaze out afresh. Of all this I was fully aware, but my mission was to obtain Davidia involucrata and in furtherance of this I did not think of causing trouble of any kind.

Having arranged for my boat to journey some fifty miles up-stream to Paishih I left Patung on the morning of April 22d, and followed a paved steep road. On the evening of the $23 \mathrm{~d}$ idem. I reached the Roman Catholic Mission station at Hsi-sha-ho and found I was the first foreigner, save Roman Catholic priests, to visit the place since Dr. Henry. I found here a Belgian priest on a visit to his converts. He - courteous and scholarly, like all his class-made me welcome. He had been the companion of the priest murdered two years before and he gave me a full account of the whole tragedy. In his Bible he carried a set of photographs of the late Père's remains-gruesome, nauseating, and horrible to look upon. The affair had taken place some fifteen miles from Hsi-sha-ho and my host said he expected trouble again this year, as, two weeks before, a party of 
outlaws had tried to burn down his house but, luckily, had failed.

Leaving the priest to his work, his gloomy forebodings on the future, and the tragic memories of his lamented companion, I took a cross-country road and on the afternoon of the 25th reached the hamlet of Ma-huang-po and the house where Dr. Henry had stayed when he found the Davidia tree on May 17, 1888. Did the people remember Dr. Henry? Did they know the K'ung-tung (local name of Davidia)? To these and similar questions they pleasantly answered in the affirmative. Would some one guide me to the tree? Certainly! We sallied forth, I in the highest of spirits. After walking about two miles we came to a house rather new in appearance. Near by was the stump of Henry's Davidia. The tree had been cut down a year before and the trunk and branches formed the beams and posts of the house! I did not sleep during the night of April $25,1900$.

On the first of May I was back at Ichang with my mind made up to collect all the plants I could in western Hupeh during the year, and in the late winter journey westward a thousand miles, and there hunt for the Davidia in the region where it was first discovered by Père David in 1869. With this resolution 
made I let the subject drift from my mind. On May 19th when collecting near the hamlet of Ta-wan, distant some five days southwest of Ichang, I suddenly happened upon a Davidia tree in full flower! It was about fifty feet tall, in outline pyramidal, and with its wealth of blossoms was more beautiful than words can portray. When figuring Henry's fruiting specimens in Hooker's “Icones Plantarum" (XX. t. 1961, [1891]) the Keeper of the Kew Herbarium wrote: "Davidia is a tree almost deserving a special mission to western China with a view to its introduction to European gardens." On beholding this extraordinary tree for the first time I no longer marvelled at the Keeper's strong language. And now with a wider knowledge of floral treasures of the Northern Hemisphere I am convinced that Davidia involucrata is the most interesting and most beautiful of all trees which grow in the north temperate regions. The distinctive beauty of the Davidia is in the two snow-white connate bracts which subtend the flower proper. These are always unequal in size-the larger usually six inches long by three inches broad, and the smaller three and one half inches by two and one half inches; they range up to eight inches by four inches and five inches by three inches. At first greenish, they become pure white as the flowers 
mature and change to brown with age. The flowers and their attendant bracts are pendulous on fairly long stalks, and when stirred by the slightest breeze they resemble huge butterflies or small doves hovering amongst the trees. The bracts are somewhat boat-shaped and flimsy in texture, and the leaves hide them considerably, but so freely are they borne that the tree, from a distance, looks as if flecked with snow. The bracts are most conspicuous on dull days and in the early morning.

Later, I found two other trees in the same neighborhood and, in localities varying from fifty to one hundred miles apart, eight others. These eleven trees were carefully watched through this anxious year of the Boxer trouble; they fruited freely, and in November I garnered a rich harvest of seeds which were despatched to England where they safely arrived in due course. In 1901, when on an expedition through the northwest of Hupeh, I discovered the Davidia in quantity and more than a hundred trees became known to me. From these hundred trees I did not secure a hundred seeds, and during subsequent visits to China extending over a decade I never again saw Davidia fruiting in the manner it did in 1900. The fruit may be likened to that of a walnut, but is more or less ellipsoid, or, more rarely, roundish 
in shape and about one and one fourth to one and three fourths inches long. The color is greenish russet and slightly reddish on one side and the flesh is very thin and gritty. The "nut" consists of a number of seeds arranged around an axis and embedded in woody tissue as hard as flint and absolutely unbreakable.

On their arrival in England in the early spring of 1901 the "nuts" were sown in various ways-some in strong heat, some in boxes and pots and placed in various temperatures, others (and the larger quantity) out of doors in a prepared seed-bed. Some were soaked in hot water, some in cold, others were filed down-in short, everything that a skilled and resourceful propagator could think of was put in operation. Weeks passed, months passed, and nothing happened. When I reached England at the end of April, 1902, not one seed had germinated and grave fears were expressed-failure almost anticipated. I made it my first business to examine the seeds. Those indoors under various conditions, save for being blackened, exhibited no apparent change and no signs of germination. Those in the seed-bed out of doors had been subjected to the winter's frost, and on digging out, a few signs of change were apparent. Some of the "nuts" exhibited slight longitudinal 
cracks from the summit to about two thirds down; in others a narrow valve-like shutter was forced back slightly and the tip of a root showed clearly. All was well. In a month or so thousands had sprouted, and from this bed an assistant and I potted up more than thirteen thousand plants, of which nearly every one grew. Of the seeds sown indoors scarcely a single one ever germinated.

I brought home with me, in 1902, three or four living plants and these were planted in various positions in the Coombe Wood nursery and in the summer grew amazingly. So, too, did the seedlings, and Davidia immediately made itself at home in England. The first to flower in England was a seedling plant in the Coombe Wood nursery in May, 1911, and a cut branch was exhibited by Messrs. Veitch at the famous Temple Show on May 23d, and received a First Class Certificate-the Royal Horticultural Society's highest award. Since that date many have flowered in various places and fruit was produced in 1915. In Kew Gardens there are now trees nineteen feet tall and thirteen inches in girth of stem.

This Hupeh plant proved to be a smooth-leaved variety of the type and in the autumn of 1903, I had the pleasure of securing in Mupin, Père David's original locality, a few hundreds of fruits of the type 
and from these more than a thousand plants were raised.

After my successful introduction of the Davidia in 1901, and its free germination in 1902, I had yet one little cup of bitterness to drain. Monsieur Maurice de Vilmorin had received seeds of the Davidia from a Roman Catholic Missionary, Père Farges, in 1897, and in 1898 one plant was raised in his arboretum at Les Barres, France. From this plant two or three cuttings and one layer were rooted. A rooted cutting was sent to Kew Gardens, another to the Jardin des Plantes in Paris, and the rooted layer to the Arnold Arboretum, where it is now growing freely. My employers were aware of this soon after I had been despatched to China in 1899, but I was not, and I took my draught when the whole story was published by Monsieur André in the Revue Horticole, August 16, 1902, p. 377. Monsieur Vilmorin's plant flowered for the first time in May, 1906, and proved to be the smooth-leaved variety and received the name of Davidia involucrata, var. Vilmoriniana, after an abortive attempt on the part of a French botanist (Monsieur L. A. Dode) to make it a distinct species.

In the late summer of 1906 I had the mortification of learning that several thousands of vigorous Davidia plants raised from my 1901 seeds had been 
ruthlessly burnt for no reason other than to gratify a whim of an unbalanced mind. Fortunately a goodly number were saved through timely action and a larger number had previously been sold and distributed. These trees in increasing numbers are now flowering each successive season. After sixteen years I have thought it of interest-and for history's sake desirable - to place on record the facts concerning the vicissitudes and difficulties which beset my path in the introduction of every seedling plant but one of this remarkable tree. 


\section{EPILOGUE}

T ORE years of my life than I care to remember have been spent in searching the remote parts of eastern Asia for new plants of value for the embellishment of western gardens. The work has not been devoid of hardship and its spice of danger; but if the art of gardening and the science of horticulture benefit thereby, the years have been well spent.

On my return in the early spring of 1915 , from a year's work in the empire of Japan, I was curious to discover, if possible, how much genuine interest existed in this country in the matter of gardens and how widespread the interest might be. After much thought I concluded that a measurable test might be made by publishing a series of articles, general yet comprehensive in character. The kindergarten element had no place in my scheme any more than that exalted in the ranks. The question could be properly answered only by the class that had some knowledge of the art, and in whom interest and love were already aroused. With this object in mind, but not divulged, I approached the Editor of the Garden Magazine. 
This gentleman encouraged me most cordially and his liberality in the matter of space, his coöperation, and the courteous manner in which he met every suggestion made the task an enjoyable one.

My question has been answered in a manner that cannot be mistaken. Letters have reached me from East and West, North and South, and from all the states which link these compass points. That there is in this country a universal awakening in the interest of outdoor gardening and to the recognition of the fact that a garden transforms a dwelling into a home, is proved to the hilt. The art of gardening and the love of hardy flowers have come to stay.

Now, in gardening and in the full and proper development of its spirit, there are four elemental forces: the Amateur, the Gardener, the Trade, the Press. Their respective spheres of usefulness are self-evident. They are co-equal and interdependent and each, by itself, can accomplish nothing. Neither can any dual or triple combination of these forces attain anything of real and lasting value. The quadruple alliance is absolutely essential to the art and love of gardening. No one of these forces is the master key, for that is held by the Spirit of man which-no matter how glossed over by the struggle for existence, by the sordid cares of every-day life, by ambitious desire 
for wealth, power, or ephemeral pleasures-ever craves for something outside itself, for those innocent joys and objects of beauty which bounteous Nature has furnished in forest and woodland, in meadow and swamp, in valley and on hill-top. And the more cultured a race or nation becomes, the more incessant grows the spirit.

The present-day energy of each of these four elemental forces could be subjected to criticism, for wholesome criticism is healthful; yet rather would I urge each to consider its function and resolve accordingly.

Arboreta, Botanic Gardens and all plant experimental institutions have a value not yet properly understood, for their collections and experiments demonstrate the wealth of material available and its adaptability to garden needs.

Horticultural exhibitions are a potent agency in furthering the knowledge and love of plants, but if the exhibits were more generally and more legibly labeled the educational value of such exhibitions would: be enormously enhanced.

Societies founded for the advancement of horticulture generally and for that of particular flowers are a natural and inevitable outcome of the desire for gardens and for mutual help and intercourse. Garden 
clubs, so rapidly being formed and so enthusiastically developed, is another most welcome sign of the awakening that is in progress. And so, in laying down his pen, a missionary of horticulture can express himself as satisfied that the people of this country are beginning to appreciate the truths admirably enunciated by Lord Bacon, when he says of gardens:

"God Almighty first planted a garden, and, indeed, it is the purest of human pleasures. It is the greatest refreshment to the spirits of man, without which buildings or palaces are but gross handiworks. And a man should ever see that when ages grow to civility and elegancy men come to build stately sooner than to garden finely, as if gardening were the greater perfection."

E. H. Wilson.

Arnold Arboretum. 



\section{INDEX}

Abies brachyohylla, II6

Abies cephalonica, 117

Abies cilicica, 117

Abies concolor, 116,118

Abies homolepis, 116

Abies Nordmanniana, 117

Abies Veitchii, II7

Abelia grandiflora, 53

Acacia, hardy in California, 37

Acanthopanax (Kalopanax ricinifolium), for summer display, 4r, 43

Acanthopanax Henryi, 94

Acanthopanax sessiliflorum, 94

Acanthopanax spinosum, 94

Acer rubrum, 176

Acer saccharinum, 176

Aconite, Winter, I74

.Aconitum Hemsleyanum, 238

Aconitum Wilsonii, 237, 238

Actinidia, 56

Actinidia arguta, 63

Actinidia chinensis, 63

Actinidia kalomikta, $6_{3}$

Actinidia polygama, 63

Adam's Needle (Yucca), 49

Aesculus parviflora, for summer display, 46

Ailanthus glandulosa, 172

Ailanthus Vilmoriniana, 172

Aitchison's Rose, Mrs. (Rosa Ecae), one of six known yellow species, 15

Akebia lobata, 64

Akebia quinata, 6

Alder (Alnus), ro5, r76

Alkaline soils, neutralization of, 153

"Almagestum", Plukenet's, 4

American Beauty Rose, wild prototype of, II

Amorpha canescens, 53

Ampelopsis aconitifolia, 74

Ampelopsis aconitifolia, var. palmiloba, 74

Ampelopsis brevipedunculata, 74

Ampelopsis Englemanii, 73

Ampelopsis heterophylla, 74

Ampelopsis humilifolia, 74

Ampelopsis megalophylla, 74

Ampelopsis micans, 74

Ampelopsis Veitchii, 73

Andromeda floribunda, $\mathrm{r}_{42}$

Andromeda polifolia, I42

Anisostichus capreolatus, 68

Apple, ro6

Apple, Chinese, 200

Apricot (Prunus Armeniaca), Io0

Apricot, Japanese, 187

Aralia chinensis, 94

Aralia spinosa, 94

Arborvitae, or White Cedar, 128

Arborvitae, Chinese, 129

Arborvitae, Giant, 127

Arbutus, Trailing, 148

Arctostaphylos uva-ursi, 149

Aristolochia durior, 56, 74

Aristolochia Kaempferi, 74

Aristolochia monpinensis, 74

Aristolochia sipho, 56, 74
Aristolochia tomentosa, 74

Aronia atropurpurea, 96

Aronia arbutifolia, 96

Aronia melanocarpa. 96

Aronia melanocarpa, var, elata, 06

Aronia melanocarpa, var. grandifolia, 96

Arrow-wood (Viburnum acerifolium), 95

Artemisia lactiflora, 234

Arnold Arboretum, number of species of Rosa recognized as indigenous to North America, 10; Southern Hemisphere shrubs unsuccessful, 36; five species of Sorbaria in cultivation, 47; species of Yucca found hardy, 49; Elsholtzia Stauntonii introduced, $5 \mathbf{r}$; Hydrangia petiolaris introduced, 68; species of Vitis found hardy, 72; evergreen climbers, 75, 76; Government investigations on plants for winter food for birds, 8r; species of Phillodendron, 93; largest collection of conifers on continent, II5; species of conifers found hardy, Ir6; Pseudotsuga taxifolia, rig; Picea pungens, Ir9; Picea Engelmanni, 121; Tsuga caroliniana introduced, 123; raises Cedar of Lebanon from cold Asia Minor seed, r26; broad-leaved Evergreens, I40; Leucothoë Catesbaei hardy, 143; Ilex crenata major not hardy, 145; Buxus microphyla hardy, 145; Evonymus radicans, var. acutus, $15 \mathrm{I}$; new species of Cotoneaster, 158; Hamamelis vernalis, 178 ; Forsythias, 192; Flowering Cherry, 195, 197, 198, 199, 200; produces Malus Árnoldiana, 208; introduces Malus Sieboldii, var. calocarpa, 209; Lilacs grown from wild seed, 214; all Lilacs hardy, 2r5; number varieties Lilac cultivated, 217 ; best dozen Common Lilacs of proven merit, 218; progression of Lilac bloom, 219 et seq; Syringa villosa introduced, 224; Syringa Wolfii received from Russia, 224; Syringa Sweginzowi latest Lilac to flower, 225; Syringa pekinensis introduced, 226: Syringa japonica introduced, 227 ; species of Rhododendrons, 25r, 252; Rhododendron poukhanense introduced, 256; list of best varieties of Rhododendrons, $26 \mathrm{r}$; large-leaved evergreen Rhododendrons hardy, 270; receives rooted layer of Davidia involucrata from France, 294

Ash, American or White, 106

Ash, Mountain, 87, 106

Asiatic Corktrees (Phellodendron), 84, 93

Astilbe Arendsi, 236

Astilbe astilboides, 235

Astilbe Davidii, 235

Astilbe grandis, 235

Astilbe japonica, 235

Attar of Roses, species cultivated for, 13

Ayrshire Roses, origination of, 12

Azalea, the three sections of, 249

Azalea, Clammy, 252

Azalea pontica, 253, 254

Azalea, Yellow, 25I

Azalea, yodogawa, 256

Azaleas, China introduced into England, 4

Azaleas, culture of, 247 
Azaleas, Ghent, 254

Azaleas, Mollis hybrids, 255

Azaleas, planting Lilies among, $3 \mathbf{2}$

Azaleas, Tsutsutsi, 255

Banks, Sir Joseph, introduces Bengal Rose into England, 1789, 5

Banksian Rose, sent from China by early plant collectors, 6 ; prototype of, 10

Barberries, for ornamental fruits, 83 ; new introductions, 165

Bartram, John, discovers Gordonia altamaha, 45

Bartram, William, introduces Gordonia altamaha into England, 45

Bearberry (Arctostaphylos uva-ursi), 149

Beauty of Glazenwood Rose, 8

Beech, 106, ro7, rog

Bengal Rose, history of, 4,5

Benzoin aestivale, 84,180

Berberis acuminata, 166

Berberis amurensis, 90

Berberis atrocarpa, 166

Berberis canadensis, 90

Berberis candidula, r 66

Berberis Darwinii, 165

Berberis Gagnepainii, 96, I65

Berberis Julianae, 96, 166

Berberis Sargentiana, 96, 166

Berberis sinensis, 90

Berberis stenophylla, 97

Berberis Thunbergii, 90

Berberis triacanthophora, 166

Berberis Veitchii, 166

Berberis verruculosa, 97, 146, 166

Berberis vulgaris, 90

Berberis Wilsonae, 90, 166

Berchemia racemosa, 65

Berchemia scandens, 65

Berckmans Louis A., rediscovers Magnolia cordata, 40

Bigelow. Dr.Wm Sturgis, sends seeds of Prunus serrulata, var. sachalinensis, to Arnold Arboretum, 200; also seed from Japan of Malus Sieboldii, var., calocarpa, 200

Bignonia capreolata, 68

Birch, ro6, 107

Birch, White, Io6

Birds, plants for winter food of 8 I

Birthworts (Aristolochia) 74

Black Alder, or Winter-berry, 87

Black fruited shrubs, and trees, 93

Blackberries, for ornamental fruits, 83

Bladder Sennas, 49

Bloomy black and blue fruited shrubs, 97

Blue fruited shrubs, 97

Blueberries (Vaccinium), 07

Blueberries for ornamental fruits, 84

Blueberries in autumn colors, ro6

Boston Ivy, 73

Boston Ivy, climbing organs of, 56

Bourbon, Isle of, China Roses introduced, 4, 7

Boursault Roses, origination of, 12

Box. Common, 145

Box, Japanese, I45

Brambles in autumn colors, 106, 100

Bretschneider, Dr. E., introducer of Prunus triloba, I92; sends seeds of Syringa oblata to Petrograd from Peking, 220; sends seeds of Syringa pubescens to Arnold Arboretum, 220; introduces Syringa villosa into Arnold Arboretum, 224: introduces Syringa pekinensis, into cultivation at Arnold Arboretum, 226

Broad-leaved evergreens, not hardy in New England, 37

Buckeye (Aesculus parviflora) for summer display, 46

Buckthorn (Rhamnus catharticus), 94
Buddleia asiatica, 168

Buddleia Davidii, 52, 167

Buddleia Davidii, var. magnifica, 58

Buddleia Farquharii, 168

Buddleia officinalis, 168

Buddleia variabilis, 52

Buffaloberry (Shepherdia argentea), 88

Bull Bay (Magnolia grandiflora), $17 x$

Burmah, Rosa gigantea introduced from, 9

Bush Honeysuckles, 89, 95, 98, 99

Butternut, ro6

Buttontree, 106

Buxus microphyla, I45

Buxus microphyla, var. japonica, I45

Buxus sempervirens, 145 , 146

Buxus sempervirens myrtifolia, 145

Cabbage Rose (Rosa centifolia), known to Pliny, 12; grown for preparation of Attar of Roses, 13

California, horticultural possibilities, 153

Callicarpa japonica, $5 \mathrm{I}$

Calluna, planting Lilies among, 3

Calluna vulgaris, 54,150

Calluna vulgaris, as ground cover for Azaleas, 247

Camellia cuspidata, 164

Camellias, introduced into England, 4

Campsis chinensis, 67

Campsis hybrida, 67

Campsis radicans, 67

Campsis radicans, var. praecox, 67

Caroline Testout Rose, wild prototype of, II

Carrieria calycina, $17 \mathrm{I}$

Caryopteris incana, 50

Caryopteris Mastacanthus, 50

Castor oil plant, gives name to Kalopanax ricinifolium, 44

Catalpa, ro6

Cats' partiality to Actinidia polygama, 63

Ceanothus hybridus, 53

Cedar, Atlas, 126

Cedar, Red, I 33

Cedar, White, 128

Cedar of Lebanon, 125; hardy trees being raised by Arnold Arboretum, 126

Cedrus atlantica, I 26

Cedrus deodara, I26

Cedrus libani, 125; Arnold Arboretum successful in raising hardy trees, 126

Celastrus, 56, 83

Celastrus articulata, 65

Celastrus flagellaris, 65

Celastrus scandens, 65

Celtis, for ornamental fruits, 84

Chamaecyparis thyoides, 129

Chamaecyparis thyoides, var. leptoclada, I33

Chamaecyparis obtusa, 127

Chamaecyparis obtusa, var. gracilis, 133

Chamaecyparis obtusa, var. nana, 130,133

Chamaecyparis obtusa, var. nana aurea, 133

Chamaecyparis pisifera, 130

Chamaecyparis pisifera, var. aurea, $\mathbf{r}_{31}$

Chamaecyparis pisifera, var filifera, $\mathrm{r} 33$

Chamaecyparis pisifera, var. flifera aurea, I33

Chamaecyparis pisifera, var. plumosa, I3I

Chamaecyparis pisifera, var. plumosa albopicta, I3I

Chamaecyparis pisifera, var. plumosa argentia, 131

Chamaecyparis pisifera, var. plumosa aurea, I3I

Chamaecyparis pisifera, var. squarrosa, 131

Chamaecyparis pisifera. var. sulphurea, $\mathbf{r}_{3} \mathbf{I}$

Checkerberry, or Wintergreen, 149

Cherokee Rose (Rosa laevigata), originally from China, 6, ro; on graves of soldiers in the South, 17 
Cherry, ro6

Cherry, Cornelian, 87

Cherry, Japanese Dwarf, 203

Cherry, Weeping, rog

Cherry Festival of Japan, 197, 199

Cherries, for ornamental fruits, 83

Cherries, Japanese, beauty of, 197,198

Cherries, Wild, rog

Chestnut, ro6, ro7, roo

Chimonanthus fragrans, 186

China Monthly Rose, prototype of, ro

China Monthly Rose and French Rose parents of Hybrid China Roses, 7

Chinese Moonseed (Sinomenium acutum), 75

Chin-yin-hwa (Lonicera japonica, var. chinensis), 67

Chiogenes serpyllifolia, 150

Chokeberry (Aronia), 06

Chrysanthemums, introduced into England from China, 4

Cinnamon Rose (Rosa cinnamomea), known to ancient writers, 12

Cinquefoil, yellow, 49

Clark, William S., introducer of Magnolia kobus, var. borealis, 185; introduces Syringa japonica into cultivation at Arnold Arboretum, 227

Clematis, climbing organs of, 56

Clematis apiifolia, 70

Clematis Armandi, 77

Clematis Armandi, f. Farquhariana, 77

Clematis coccinea, 70

Clematis Fargesii, 70

Clematis glauca, 70

Clematis glauca, var. akebioides, 70

Clematis florida, 60

Clematis heracleaefolia, 50

Clematis Jackmani, 69

Clematis lanuginosa, 60

Clematis montana, 60

Clematis montana, var. rubens, 69

Clematis montana, var. Wilsonii, 70

Clematis paniculata, 70

Clematis patens, 69

Clematis stans, 50

Clematis tangutica, 70

Clematis Viticella, 60

Clerodendron trichotomum, 45

Clethra acuminata, 46

Clethra alnifolia, 46

Clethra canescens, 47

Clethra tomentosa, 46

Climbing plants, climbing organs of, 56 ; pergolas for, 57 ; trellises, 58 ; on trees, 59 ; best situations for, 59

Climbing shrubs, evergreen, 75, 76

Climbing shrubs, hardy, 55-77

Cocculus Thunbergii, 75

Cocculus trilobus, 75

Coignet, M., introducer of Rambler Rose, 9

Collett, General, introduces Rosa gigantea from Burmah,

Coloring of the leaves in autumn, ror

Colutea arborescens, 49

Colutea cilicica, 49

Colutea orientalis, 49

Colville's Nursery, London, introducers of Rosa microphylla, or Rosa Roxburgii 7

Comptonia, planting Lilies among, $3 \mathrm{I}$

Coralberry (Symphoricarpos orbiculatus), 99

Corema Conradiu, 149

Corktrees, Asiatic (Phellodendron), 93

Cornel, ro6, i ro

Cornel, Silky (Cornus Amomum), 08

Cornus, for ornamental fruits, 83

Cornus alba, 99

Cornus Amomum, 98
Cornus Arnoldiana, 99

Cornus candidissima, 90

Cornus circinata, 99

Cornus florida, 87

Cornus Heyeri, 99

Cornus mas, 87

Cornus mas, var. xanthocarpa, 87

Cornus obliqua, 98

Cornus occidentalis, 99

Cornus oreophilus, 99

Cornus racemosa, 99

Cornus rugosa, 99

Cornus sanguinea, 99

Cornus stolonifera, 99

Corydalis thalictrifolia, $24 \mathrm{I}$

Corydalis Wilsonii, $24 \mathrm{I}$

Corylopsis pauciflora, 170

Corylopsis platypetala, 170

Corylopsis sinensis. 170

Corylopsis spicata, 170

Corylopsis Veitchiana, 170

Corylopsis Willmottiana, 170

Cotoneaster, for ornamental fruits, 83

Cotoneaster, new species of, 158

Cotoneaster acutifolia, 06

Cotoneaster acutifolia, var. villosula, 96

Cotoneaster adpressa, oI

Cotoneaster amoena, 159

Cotoneaster bullata, 91

Cotoneaster bullata, var. macrophylla, or

Cotoneaster Dammeri, or, 159

Cotoneaster disticha, $9 \mathrm{r}$

Cotoneaster divaricata, or

Cotoneaster faveolata, 96

Cotoneaster Franchettii, 159

Cotoneaster Harroviana, 158

Cotoneaster Henryana, 150

Cotoneaster horizontalis, $9 \mathrm{r}$

Cotoneaster horizontalis, var. perpusilla, 91

Cotoneaster humifusa, 159

Cotoneaster hupehensis, or

Cotoneaster lucida, 96

Cotoneaster monpinensis, 96

Cotoneaster multiflora, $9 \mathrm{x}$

Cotoneaster nitens, 96

Cotoneaster pannosa, $156, x_{5} 8$

Cotoneaster racemiflora, $9 \mathrm{r}$

Cotoneaster racemiflora, var. soongorica, $9 \mathrm{I}$

Cotoneaster saliciiolia, 92,158

Cotoneaster salicifolia, var. floccosa, 92, 158

Cotoneaster salicifolia, var. rugosa, 92, 158

Cotoneaster vulgaris, 96

Cotoneaster, Willow-leaved, 158

Coventry, Lord introduces Koblreuteria into England, 4I

Cowberry (Vaccinium Vitis-idaea), 148

Crabapples, 79, 83, 93, 203, 205

Crataegus, for ornamental fruits, 83,85

Crataegus Arnoldiana, 85

Crataegus cordata, 85

Crataegus crus-galli, 86

Crataegus monogyna, 86

Crataegus nitida, 85

Crataegus Oxyacantha, 86

Crataegus pinnatifida, 86

Crataegus pruinosa, 86

Crataegus punctata, 86

Crataegus succulenta, 85

Crimson Monthly Rose, Fairy Rose a variant, 7

Crimson Rambler Rose, origin of, 9

Cross-vine (Anissotichus capreolatus), 68

Crowberry (Empetrum nigrum), 149

Currant, for ornamental fruits, 83

Cypress (Taxodium) 113

Cypress, Chinese (Glyptostrobus), II4

Cytisus capitatus, 49

Cytisus nigricans, 49 
Damask Rose, one of the parents of Hybrid Perpetual, or Remontant, Roses, 7; known to ancient writers, 12; grown for preparation of Attar of Roses, 13

Daphne Cneorum, 147, 18 I

Davidia involucrata, Story of the, Mr. Wilson sent by Messrs. Veitch to China, 275; en route meets Professor Sargent and Mr. Jackson Dawson at Arnold Arboretum, 276; reaches Hongkong, 276; by small boat and overland to Laokai, 278; detained two months on account of Boxer uprising, 270; thought to be a spy, 281; Proceeds on journey and meets at Mengtsze, W. F. S. Spinney who with his family had escaped the mob, 283; meets Dr. Henry at Szemao, 285; returns to Hongkong, 286; Arrives at Ichang, his headquarters for two years, and outfits for expedition, 286; through hostile country to location of Dr. Henry's tree, and finds it destroyed! 280 weeks later accidentally discovers a Davidia in full flower, 290; later discovers ten others and collects quantity of soeds which sends to England, 291; On return to England finds that one plant had been raised in France from seeds antedating his introduction, 294

Davidia involucrata, var. Vilmoriniana, 294

Dawson, Jackson, met in Boston by Mr. Wilson en route in search of Davidia, 276

De Candolle, referred Glycine sinensis to Wistaria genus, 60

D'Incarville, Father, sends seeds of Sophora japonica to France, 42

Deodar, 126

Deutzia discolor, 169

Deutzia longifolia, r6o

Deutzia longifolia, var. Veitchii, I69

Deutzia mollis, I6o

Deutzia Schneideriana, I60

Deutzia Schneideriana, var. laxifolia, I69

Deutzia Wilsonii, I60

Deutzias, planting Lilies among, 31

Deutzias, valuable for forcing, 170

Dexter, F. Gordon, first to send Lilium auratum to America, 2I; also first double purple variety of Japanese Wistaria, $\mathrm{O}_{2}$

Dirca palustris, 83,180

Diospyros virginiana, 84, 93

Dogwood, Poison, 107

Dogwoods, for ormamental fruit, 83

Douglas David, introduces Douglas Fir (Pseudotsuga taxifolia) into England, $1 \times 8$

Dutchman's Pipe (Aristolochia durior), 56, 74

Dwarf conifers, 132

Dwarf trees, Japanese, 124, I 29, I88

Dwarf trees in pots, Japanese, I88, 203

Dyes made from Sophora japonica, 43

Easter Lily, type of group, 25

Elaeagnus, for ornamental fruits, 84

Elaeagnus angustifolia, 88

Elaeagnus longipes, 88

Elaeagnus umbellata, 88

Elder, ro5

Elderberry (Sambucus canadensis), 94

Elderberries, for ornamental fruits, 83

Elm, ro6, 100, r76

Elsholtzia Stauntonii, introduced into Arnold Arboretum by Mr. J. G. Jack, 5I

Empetrum nigrum, 149

Epigaea repens, 148

Eranthis hyemalis, 174

Erica carnea, 53 , 180

Erica cacnea alba, 180

Erica cinerea, 54

Erica Mackaii, 54

Erica Stricta, 54
Erica Tetralix, 54

Erica vagans, 53

Erica vagans, var. alba, 53

Erica vagans, var. grandiflora, 53

Erica vagans, var. rubra, 53

Ericas, 150

Ericas, as ground cover for Azaleas, 247

Ericas, planting Lilies among, 3 I

Eucalyptus, hardy in California, 37

Evans, Thomas, from China sends first Rambler Rose to England, 5

Evergreen climbers, 75, 76

Evonymus, for ornamental fruits, 83

Evonymus alatus, 88

Evonymus Bungeanus, 88

Evonymus kewensis, 76, 151

Evonymus minimus, 76

Evonymus radicans. 75, I5I

Evonymus radicans, var. acutus, $15 \mathrm{I}$

Evonymus radicans, var. minimus, 151

Evonymus radicans, var. vegetus, 75,76, r 51

Evonymus radicans, climbing organs of, 57

Fairy Rose (Rosa chinensis, var. minima) introduced into England from Mauritius, 7

Farges, Père, sends first seeds of Davidia involucrata to Europe, 294

Father Hugh's Rose (Rosa Hugonis), one of six known yellow species, I5

Ferns, planting Lilies among, $3 x$

Fir, Douglas (Pseudotsuga taxifolia), II8

Firs (Abies), I 16

Fitzgerald, Edward, Rose on grave of, 16

Flowering Dogwood, 87

Foreign trees and shrubs in the United States, 36

Forsythia europae ro3

Forsythia intermedia, 192, 193

Forsythia intermedia spectabilis, 192, 193

Forsythia suspensa, 192

Forsythia viridissima, 192

Forsythias, or Golden Bells, ro2

Fox Grape (Vitis labrusca), 73, 1 I0

Fortune, Robert, plant collector in China, sends to England, Rosa odorata, var. pseudoindica and Rosa Fortuneana, 8; discovers Actinidia chinensis, 64 ; introduces Jasminum nudiflorum, r87; introduces Syringa oblata into England, 220

Fraser, John, introduces Rhododendron catawbiense into England from America. 264

Fraxinus americana, Io6

French Rose (Rosa gallica), with Rose Edward, parents of Hybrid Bourbon Roses, 7; known to Pliny, Ir; grown for preparation of Attar of Roses, $r_{3}$

Frost Grape (Vitis cordifolia), 73

Fruit trees, floral charms of, 196

Garland-flower (Daphne cneorum), 147, I8I

Garden Magazine, article on Buddleia, 52

Gaultherfa procumbens, 149

Gaylussacia brachycera, 148

Genista tinctoria, var. elata, 49

Gerard, cultivates Lilac in London in $\mathrm{I597}, 2 \mathrm{I}_{3}$

Giant Lily, type of group, 25

Gibbes, Prof. L. R., discoverer of Tsuga caroliniana, 123

Gilbert, Mr., exhibitor of "The Engineer" Rose, afterward named the Crimson Rambler,

Ginkgo biloba, ro6, 135

Girald, Père G., Syringa affinis, var. Giraldii named after, 219

Gleditsia, ro6

Glycine frutescens, 60

Glycine sinensis, 60 


\section{Glyptostrobus, 1 r4}

Gooseberry, for ornamental fruits, $8_{3}$

Gordon, J., introduces Sophora japonica into England 42

Gordonia altamaha, discovered by John Bartram and introduced by his son, William, 45

Grape, Fox (Vitis labrusca), 73, I ro

Grape, Frost (Vitis cordifolia), 73

Grape, Oregon, 146

Grape, Sugar (Vitis rupestris), 73

Grape, Summer (Vitis aestivalis), 72

Grapevine, climbing organs of, 56

Grapevines (Vitis), 70

Greenbriers (Smilax), 75

Greville, Charles Francis, introduces "Seven Sisters" Rose (Rosa multiflora, var. platyphylla), 5

Gronovius, writes in 1704 , of Bengal Rose, 5

Ground cover, plants for, $147,148,149,159$

Ground cover for Azaleas, 247

Guelder Rose (Viburnum Opulus, var. xanthocarpum), 92

Gum, Blue (Eucalyptus), II3

Hackberry, for ornamental fruits, 84

Hackmatack or Tamarack, 134

Hall, Dr. George R., sends first seeds of Japanese Wistaria to America, 62; brings collection valuable plants from Japan, 184; introduces Malus Halliana into the United States, 206

Hall's Honeysuckle (Lonicera japonica, var. Halliana), 67

Hamamelis japonica, 178

Hamamelis mollis, 178

Hamamelis vernalis, 178

Hamamelis virginiana, 177, 178

Hamamelis virginiana, var. arborea, 178

Harison Rose, probable derivation of, 16

Hazelnut (Corylus), I76

Hawthorn, 106

Hawthorns, for ornamental fruits, 83,85

Heath (Erica carnea), I80

Heath, Cornish, 53

Heath, Downy (Erica cinerea), 54

Heath, Irish (Doboreia polifolia), 54

Heaths, hardy, 53

Hedera Helix, I50

Hedera Helix, var. amurensis, 77

Hedera Helix, var. canariensis, 77

Hedera Helix, var. chrysocarpa, 77

Hedera Helix, var. colchica, 77

Hedera Helix, var. crenata, 77

Hedera Helix, var. deltoidea, 77

Hedera Helix, var. rhombea, 77

Hedera Helix, climbing organs of, 57

Hemlock (Tsuga canadensis) $\mathrm{Ir}_{4}, \mathrm{I} 22$

Hemlock, Carolina, 123

Henry, Dr. A., finds prototype of Rosa chinenesis, var. spontanea, Io; visited by Mr. Wilson in quest of Davidia, 275

Henry, L. , originator of Syringa Henryi, 228

Hercules Club (Aralia spinosa), 94

Hibiscus syriacus, for summer resorts, 39

Hickory, 106

Highbush Cranberry (Viburnum americanum), 9I

Highland Park, Rochester, display of Lilacs at, 217

Hobble Bush (Viburnum alnifolium), 95

Hogplum, Chinese, 173

Holly, for ornamental fruits, 83

Holly, new varieties of, 164

Holly, American, 143

Holly, English, 87

Holly Mountain, 88

Honey Locust (Ǵleditsia), 106

Honeysuckle, Bush, 89, 95, 98, 99, I 93
Honeysuckle, Swamp, 252

Honeysuckles, European, 66

Honeysuckles, for fruits and flowers, 79, 82

Horsechestnut, ro6

Hortensia, for summer resorts, 39

Huckleberry, Box, 148

Hume, Sir Abraham, introduces Tea-scented Rose into England from China, 5

Hunnewell Pinetum, Pseudolarix Kaempferi at,

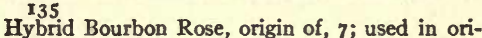
ginating Hybrid Perpetual or Remontant Roses, 7

Hybrid China Rose, used in originating Hybrid Perpetual or Remontant Roses, 7; parentage of, 7

Hybrid Perpetual or Remontant Roses, parentage of, 8

Hybrid Perpetual and Tea Rose, parents of Hybrid Tea Roses, 8

Hybrid Tea Roses, parentage of, 8

Hydrangea, Climbing (Hydrangea petiolaris), 68

Hydrangea opuloides, var. otsaka for summer display, 39

Hydrangea paniculata, for summer resorts, 39

Hydrangea petiolaris, 68

Hydrangea petiolaris, climbing organs of, 57

Hydrangeas, for summer resorts, 39

Hypericum patulum, var. Henryi, 50

Nlex, for ornamental fruits, 83

Ilex Aquifolium, $87,143,165$

Ilex Aquifolium, var. fructu-luteo, 87

Ilex crenata, 96,144

Ilex corallina, 165

Ilex Fargesii, 164

Ilex Franchetiana, 164

Ilex glabra, 96,144

Ilex laevigata, 88

Ilex opaca, 87,143

Ilex Pernyi, 164

Ilex Sieboldii, 88

Ilex Sieboldii, var. fructu-albo, 88

Ilex Veitchii, I6

Ilex verticillata, 88

Ilex verticillata, var. chrysocarpa, 88

Ilex yunnanensis, $16_{5}$

"Index Kewensis" number of species of Rose enumerated in, ro

Indigofera amblyantha, 51

Indigofera decora, 50

Indigofera Gerardiana, 51

Indigofera Kirilowii, 50

Indigoferas, planting Lilies among, 3 I

Inkberry (Ilex glabra), 96, I 44

Irritability or sensitiveness in plants, 55

Iris chrysographes, 239

Iris Wilsonii, 239

Irish Ivy (Hedera Helix, var. canariensis), 77

Itea ilicifolia, 165

Ivy, climbing organs of, 57

Ivy, for ornamental fruits, 83

Jack, J. G., introduces Elsholtzia Stauntonii into Arnold Arboretum, 5I; introduces Rhododendron poukhanense, 256

Japanese dwarf trees, 124, 188, 203

Jasminum Beesianum, 167

Jasminum nudiflorum, 187

Jasminum primulinum, 156, 167, 286

Jenner, Mr., original owner of "The Engineer" Rose, afterward named Crimson Rambler, 8

Juniper, Chinese, 133

Juniper, Common, 134

Juniperus chinensis, 133

Juniperus chinensis, var. Sargentii, I32 
Juniperus chinensis, var. Pfitzeriana, I33

Juniperus communis, $\mathrm{I} 34$

Juniperus communis, var. oblonga, 134

Juniperus horizontalis, 132

Juniperus procumbens, 132

Juniperus rigida, $I_{34}$

Juniperus squamata, $\mathbf{I}_{32}$

Juniperus virginiana, 133

Juniperus virginiana, var. tripartita, 133

Kalmia angustifolia, I42

Kalmia glauca, $\mathbf{I}_{42}$

Kalmia latifolia, I40, I4I

Kalmia latifolia, var. alba, I4r

Kalmia latifolia, var. fuscata, I4I

Kalmia latifolia, var. myrtifolia, I4I

Kalmia latifolia, var. obtusata, I4I

Kalmia latifolia, var. polypetala, I4I

Kalmia latifolia, var. rubra, I4I

Kalopanax ricinifolium, 4I, 43, 94

Kerr, William, plant collector in China sends out, 1807 , Rosa Banksiae, 6

Kew Gardens, Forsythia europae introduced into, 193

Killarney Rose, wild prototypes of, II

Köelreuteria apiculata, now in cultivation, 42

Köelreuteria paniculata, for summer display, 4 I

Lace-wing Fly, Rhododendron pest, $27 \mathrm{I}$

Lady Hillingdon Rose, wild prototype of, II

La-mei-hwa shrub, I86

Larch (Larix), I13

Larch, Golden (Pseudolarix), II 3

Larches, 134

Larix decidua, 134

Larix Kaempferi, 134

Larix laricina, $\mathbf{1} 34$

Laurel, Mountain, $\mathrm{I}_{40}$

Laurel, Pale, I42

Laurel, Sheep, $\mathbf{I}_{42}$

Lavender, Lilies planted with, 3 I

Leatherwood, for ornamental fruits, 83

Leatherwood' (Dirca palustris), 180

Lee and Kennedy, introduce Rosa rugosa into England, 1796, 6

Lemoine, Victor, hybridizer, 169

Lemoine et Fils, V., introducers of Syringa affinis, var. Giraldii, 220

Lespedeza bicolor, $5 \mathrm{I}$

Lespedeza crytobotrya, 5 I

Lespedeza formosa, 51

Lespedezas, planting Lilies among, 3I

Leucothoë Catesbaei, I43

Libocedrus (Incense Cedar), 113

Ligustrum Delavayanum, $\mathrm{I}_{3}$

Ligustrum Henryi, 163

Ligustrum Prattii, 163

Ligustrum vulgare, 96

Ligustrum vulgare, var. foliosum, 96

Lilac, Common, $2 I_{3}$

Lilac, Himalayan, 225

Lilac, Hungarian, 21 4, 224, 228

Lilac, Japanese Tree, 215

Lilac, Persian, 214, 221

Lilac, Rouen, 228

Lilac, Summer, 52, 167

Lilacs, how propagated, 216

Lilacs, Hybrid, 227

Lilacs, soil requirements, 215

Lilacs, Tree, 226

Lilacs, Winter, 168

Lilies, how they grow, 19; beginnings of bulb growing by Japanese, 22; range of the genus, 24, 25; botanical groups, 25; grouping as hardy and tender varieties, etc., 25 ; detest lime, 26; require drainage, 26 ; varieties from Thibet and China, 29; soil requirements, 23, 26, 3I,
34; importance of mulching, 32, 34; planted among shrubs, 31; root systems of, 32; how and when to plant, 33

Lilium auratum, introduced, $\mathbf{1 8 6 2}$, in England and America, 2r; esteemed in Japan, as food, 2I; most common in Japan, 22; difficulty in growing, 22, 35; soil requirements, 23; selection of bulbs for planting, 24; type of group 25; planted among Rhododendrons, 31; root system of, 32; satisfactory in every garden, 35

Lilium auratum, var. platyphyllum, 22

Lilium, botanical groups, 25

Lilium candidum, 20, 26, 35

Lilium croceum, satisfactory in every garden, 35

Lilium giganteum, 25, 26

Lilium Henryi, 25, 30, 31, 32, 35, 242

Lilium Hansonii, 31, 35

Lilium longiflorum, 25,26

Lilium pardalinum, 27, 31, 35

Lilium philippinense, 25

Lilium neilgherrense, 25

Lilium nepalense, 26

Lilium martagon, 26

Lilium myriophyllum, or Regal Lily, 28

Lilium regale, 25, 26, 28, 32, 35, 242

Lilium Sargentiae, 29, 35

Lilium speciosum, 3I, 35

Lilium superbum, 27, 3I, 35

Lilium sulphureum, 26

Lilium testaceum, 26, 35

Lilium tigrinum, 20, 25, 35, 242

Lilium Thayerae, 30,35

Lilium umbellatum, 25,35

Lime, not for lilies, 26

Lindley's Rose (Rosa xanthina), introduced in 1908 by F. N. Meyer, of United States Department of Agriculture, 15

Ling (Calluna vulgaris), 53,54

Linden, 106, 100

Lindens, for summer display, 40

Lobb, William, introduces Giant Arborvitae (Thuja plicata), into England, I27

Locust (Robinia), ro5

Lonicera Brownii, 66

Lonicera Brownii, f. fuchsioides, 66

Lonicera, Caprifolium, 56, 67

Lonicera chrysantha, 89

Lonicera coerulea, 98

Lonicera coerulea, var. altaica, 98

Lonicera coerulea, var. graciliflora, 98

Lonicera coerulea, var. villosa, 98

Lonicera flava, 66

Lonicera fragrantissima, 193

Lonicera glaucescens, 66

Lonicera Heckrotti, 66

Lonicera Henryi, 76, I5I

Lonicera hirsuta, 66

Lonicera involucrata, 96

Lonicera japonica, var. chinensis, 67

Lonicera japonica, var. Halliana, 67

Lonicera Maackii, 90

Lonicera Maackii, var. podocarpa, 90

Lonicera micrantha, 92

Lonicera minutiflora, 92

Lonicera Morrowii, 89, 92

Lonicera muscaviensis, 89

Lonicera muendeniensis, 89

Lonicera nervosa, 95

Lonicera nigra, 95

Lonicera nitida, 163

Lonicera Percilymenum, 66

Lonicera Periclymenum, var. belgica, 67

Lonicera pileata, $\mathrm{I}_{3}$

Lonicera prolifera, 66

Lonicera quinquelocularis, 99

Lonicera Ruprechtiana, 89

Lonicera Ruprechtiana, var. xanthocarpa, 92 
Lonicera sempervirens, 66

Lonicera Standishii, ro3

Lonicera Sullivantii, 66

Lonicera syringinantha, 90

Lonicera syringinantha, var. Wolfii, 90

Lonicera tatarica, 89

Lonicera tatarica, f. lutea, 92

Lonicera thibetica, 90

Lonicera Xylosteum, 89

Lycium halimifolium, 65

Macartney, Lord, introduces Rosa bracteata into England from China, 6

Madonna Lily (Lilium candidum), 20, 33

Magnolia Campbellii, 186

Magnolia conspicua, 182

Magnolia cordata, discovered by Michaux, 40

Magnolia Delav 1 yi, $17 x$

Magnolia denudata, 182,184

Magnolia denudata, var. purpurascens, 182

Magnolia discolor, 184

Magnolia glauca, for summer display, 40

Magnolia grandiflora, $x 7$

Magnolia Halleana, 184

Magnolia kobus, 185

Magnolia kobus, var. borealis, 185

Magnolia Lennei, 184

Magnolia liliflora, 184

Magnolia obovata, 184

Magnolia obovata, var. discolor, $\mathrm{I}_{3} 3$

Magnolia purpurea, 184

Magnolia rustica rubra, 184

Magnolia Soulangeana, 184

Magnolia stellata, 185

Magnolia stellata, var., rosea, $x 85$

Magnolias, 182

Mahonia aquifolium, 97, $x_{46}$

Mahonia repens, 97, 146

Mahonia japonica, 07

Maidenhair Tree (Ginkgo), xo6, ro7, 135

Malus, for ornamental fruits, 83

Malus angustifolia, 204

Malus atrosanguinea, 207

Malus baccata, 204

Malus coronaria, 204

Malus floribunda, 207

Malus fusca, 204

Malus glaucescens, 204

Malus Halliana, 206

Malus Halliana Parkmanii, 206

Malus ioensis, 204

Malus prunifolia, var. rinki, 2 Io

Malus ringo, 2 ro

Malus Sargentii, 2 Ir

Malus Scheideckeri, 205

Malus Sieboldii, 208

Malus Sieboldii, var. arborescens, 200

Malus Sieboldii, var. calocarpa, 209

Malus spectabilis, 205, 205

Malus toringo, 208

Malus zumi, 200

Maple, Mountain, 106

Maple, Red, I01, I02, 106, 107, I76

Maple, Silver, I06, I76

Maple, Striped, ro6

Maple, Sugar, 102, 106, 108

Maples, ro7

Maries, Charles, introducer of Hamamelis mollis, 178

Matrimony Vine (Lycium chinense), 65

Mauritius, Fairy Rose (Rosa chinensis, var., minima), introduced into England from, 7

Mayflower, or Trailing Arbutus, I 48

McLaren, California horticulturist, $x 55,158$

Meconopsis integrifolia, 230

Menispermum canadense, 75

Menispermum dauricum, 75
Menzies, Archibald, discoverer of Pseudotsuga taxifolia, Ir8

Meratia praecox, 186

Meyer, F. N., introduces Lindley's Rose (Rosa xanthina), 15

Mezereon (Daphne mezereum), $r 80$

Michaux, named Rosa laevigata, 6; discoverer of Magnolia cordata, 40

Mrs. George Shawyer Rose, wild prototype of, II

Mrs. Chas. Russell Rose, wild prototype of, II

Mitchella repens, 150

Moonseeds (Menispermum), 75

Mortier, hybridizer of Azaleas, 254

Moss Rose (Rosa centifolia, var. muscosa), known to ancient writers, $x_{2}$

Muenden Botanic Garden, origination of Lonicera muendeniensis at, 90

Mulberry, 84, 106

Mulching, important for Lilies, 32

Musk Rose, 8 , 12, 156

Nèe, discoverer of Giant Arborvitae (Thuja plicata), 127

Nemopanthus mucronatus, 88

Noisette Roses, parentage of, 8

Nuttall, gave name to Wistaria genus, 60

Nyssa, for ornamental fruits, 84

Nyssa sylvatica, 108

Oak, Black, rog

Oak, English, rog

Oak, Red, ro7, ro8, rog

Oak, Scarlet, ro6, 108

Oak, Swamp, rog

Oak, White, 106, 108, 109

Olearias, planting Lilies among, $3 \mathbf{x}$

Oleasters (Elaeagnus), 88

Orange and yellow fruited shrubs, 92

Osmanchus armatus, $\mathrm{r} 67$

Osmanthus Delavayi, I6

Osteomeles Schwerinae, 16r

Oxydendrum arboreum, for summer display, 40

Pachysandra terminalis, $\mathbf{1 4 7}$

Pachystima Canbyi, 148

Pachystima Myrsinites, $\mathbf{r}_{4} 8$

Pacific Slope, horticultural possibilities, $x_{53}$

Panama-California Exposition, floral displays at, r 53

Panama-Pacific International Exposition, floral displays at, $\mathrm{I} 53$

Panther Lily (Lilium pardalinum), 27, 3 r

Pagoda Tree (Sophora japonica), for summer display, 4I; introduced into France from China by Father d'Incarville, 42

Parkman, Francis, introduces Lilium auratum in America, 2I; first cultivates double purple variety of Japanese Wistaria in America, 62; first in United States to cultivate Malus Halliana, 206

Parks, John Damper, plant collector in China, sends out 1824, Rosa Banksiae, var. lutea, and Rosa odorata, var. ochroleuca, 6

Parry, Dr., discoverer of Picea pungens, $x 20$

Parsons, Samuel B., receives first seeds of Japanese Wistaria sent to America, 62; acquires collection of Japanese plants from Dr. Geo. R. Hall, 184

Parthenocissus Henryana, 73

Parthenocissus quinquefolia, 73

Parthenocissus quinquefolia, var. San Paulii, 73

Parthenocissus Thomsonii, 74

Parthenocissus tricuspidata, 56, 73

Parthenocissus vitacea, 73

Partridgeberry (Mitchella repens), 150

Peach, 106, I88

Pear, 106 
Pentanthera Azaleas, 249, 250

Peonies, Mouton, introduced into England from China, 4

Pepperbush (Clethra), for summer display, 46

Pergolas, appropriateness of, 57 ; vines for, 169

Periploca graeca, 64

Periploca sepium, 64

Periwinkle, Lesser, 147

Pernettya mucronata, 100

Pernettya rupicola, ro

Perennial plants, new varieties from China, 230; conditions necessary to cultivation of, 232

Perry, Commodore, influence on horticulture, 21

Persimmon (Diospyros virginiana), 84, 93

Petrograd Botanic Garden, Lonicera muscaviensis originated at, 89

Pheasants, shrubs for food of, 92

Phellodendron (Asiatic Corktree), 93

Phellodendron, for ornamental fruits, 84

Phellodendron amurense, 94

Phellodendron chinense, 94

Phellodendron japonicum, 94

Phellodendron Lavallei, 94

Phellodendron sachalinense, 94

Photinia Davidsoniae, 160

Photinia glabra, 160

Photinia serrulata, 160

Picea Abies, 120

Picea Abies, var. Clanbrassiliana, 132

Picea Abies, var. Elwangeri, 132

Picea Abies, var. Gregorgana, 132

Picea Abies, var. nana, 132

Picea Abies, var. procumbens, $x_{32}$

Picea Abies, var. pumila, 132

Picea canadensis, 121

Picea Engelmannii, 121

Picea excelsa, 120

Picea omorika, I 21

Picea orientalis, 122

Picea pungens, I I9, I32

Pieris floribunda, $\mathbf{r}_{42}$

Pieris japonica, 143

Pine, Austrian, 124

Pine, Balkan White, 123

Pine, Foxtail, 123

Pine, Jack, 125

Pine, Japanese Black, 124, 125

Pine, Japanese, Table, 132

Pine, Japanese Umbrella, 126

Pine, Japanese White, 124

Pine, Korean Nut, 124

Pine, Mountain, r $_{3}$

Pine, Red, 124

Pine, Scots, 124

Pine, Scrub, I25

Pine, Swiss, 124

Pine, White, $x_{14}, x_{23}, x_{3} x_{1}$

Pinus Banksiana, 125

Pinus cembra, 124

Pinus densiflora, var. umbraculifera, 132

Pinux flexilis, $\mathbf{2} 3$

Pinus koraiensis, 124

Pinus montana, $13 \mathbf{r}$

Pinus monticola, 123

Pinus mughus, 132

Pinus nigra, 124

Pinus parvifloria, 124

Pinus peuke, 123

Pinus pumilio, 132

Pinus resinosa, 124

Pinus Strobus, II 4,123

Pinus Strobus, var. nana, r3r

Pinus sylvestris, I 24

Pinus Thunbergii, 124, 125

Pinus virginiana, 125

Pistacia chinensis, I 72

Plant collectors first sent to China, 6, 8, 9
Pliny, Roses known by, 12

Plukenet, in his "Almagestum," 1679, mentions new Roses from China, 4

Plum, ro6

Plum Gardens of Tokyo, 187

Plums, for ornamental fruits, 83

Poison Dogwood, ro7

Poison Ivy, 106, 110

Polygonum baldschuanicum, 66

Polygonium multiflorum, 66

Poplar, 106, 177

Populus lasiocarpa, 173

Populus Simonii, I74

Populus suaveolens, 174

Populus szechuanica, 174

Populus Wilsonii, 174

Potentilla fruticosa, 50

Potentilla fruticosa, var. parvifolia, 50

Potentilla fruticosa, var. Veitchii, $5 \circ$

Primrose, China, introduced into England, 4

Primrose hybrids, 240

Primula hybrids, "Unique" and "Unique Improved" 240

Primula Cockburniana, 239

Primula pulverulenta, 239

Primula pulverulenta, var., Mrs. R. V. Berkeley, 240

Primula Veitchii, 239, 24r

Privets (Ligustrum), 96

Provence Rose (Rosa provincialis), known to Pliny, 12

Prunus, for ornamental fruits, $8_{3}$

Prunus ansu, 100

Prunus Armeniaca, 190

Prunus Davidiana, I89

Prunus glandulosa, ror

Prunus incisa, 202

Prunus japonica, ror

Prunus Lannesiana, 201, 202

Prunus Lannesiana Gioiko, 202

Prunus Lannesiana grandiflora, 201

Prunus mira, 180

Prunus mandschurica, 190

Prunus mume, 187,190

Prunus Persica, 188

Prunus pseudo-cerasus, 20r

Prunus Sargentii, 200

Prunus serrulata, 20r

Prunus serrulata albo-rosea, 20r

Prunus serrulata "James H. Veitch," 201

Prunus serrulata, var. sachalinensis, 200, 202, 203

Prunus Sieboldii, 20r, 202

Prunus subbirtella, ro8

Prunus subhirtella, var. pendula, 199

Prunus tomentosa, ror

Prunus triloba, ror

Prunus triloba plena, rgr

Prunus yedoensis, 200, 203

Pseudolarix Kaempferi, r 34

Pseudotsuga taxifolia, I 18

Pussy Willows (Salix), i77

Pyracantha angustifolia, 160

Pyracantha crenulata, 92,160

Pyracantha coccinea, 92, r60

Pyracantha coccinea, var. Lalandii, 92, 160

Quince, ro6

Rambler Rose, introduced into England from China, 4, 5; into France from Japan, 9; wild prototype of, $\mathbf{I I}$

Raspberries, for ornamental fruits, 83

Red fruits, trees, and shrubs with, 84

Redwoods (Sequoia), II3

Reeves, John, sends Wistaria sinensis to England from Canton, China, 60 
Remontant or Hybrid Perpetual Roses, parentage of, 8

Retinispora obtusa nana, 130

Rhamnus, for ornamental fruits, 83

Rhamnus alpinus, 94

Rhamnus catharticus, 94

Rhamnus davuricus, 94

Rhamnus Frangula, 94

Rheum Alexandrae, 237

Rhododendron Albrechtii, 257

Rhododendron Album elegans, $26 \mathrm{r}$

Rhododendron Album grandifiorum, 26I

Rhododendron altaclarense, 267

Rhododendron amoenum, 256

Rhododendron arborescens, 252

Rhododendron arboreum, 266, 273

Rhododendron arbutifolium, 259

Rhododendron Atrosanguineum, 26r, 273

Rhododendron austrinum, 252

Rhododendron azaleoides, 266

Rhododendron Boule de Niège, 266

Rhododendron brachycarpum, 269, 270, 271

Rhododendron calendulaceum, 251, 254

Rhododendron californicum, 269

Rhododendron calophytum, 273

Rhododendron candidum, 252

Rhododendron canescens, $25 \mathrm{I}$

Rhododendron Caractacus, 26 r

Rhododendron carolinianum, 257

Rhododendron catawbiense, $264,265,269,270$

Rhododendron catawbiense album, $26 \mathrm{r}$

Rhododendron caucasicum, 264, 265, 260, 270

Rhododendron caucasicum album, 266

Rhododendron, Charles Dickens, 273

Rhododendron chrysanthum, 269, 270

Rhododendron ciliatum, 259

Rhododendron Coriaceum, 266

Rhododendron dahuricum, 194, 259

Rhododendron delicatissimum, $26 \mathrm{I}$

Rhododendron Everestianum, 26r

Rhododendron Fargesii, 273

Rhododendron ferrugineum, 258

Rhododendron flammeum, 252, 253

Rhododendron flavidum, 260

Rhododendron flavum, 253

Rhododendron Fortunei, 267

Rhododendron Griffithianum, 267

Rhododendron H. W. Sargent, 261, 273

Rhododendron Henrietta Sargent, 261

Rhododendron hirsutum 258

Rhododendron Hybrid Maximum, 266

Rhododendron Hybrids, 260, 266, $27 \mathrm{I}, 273$

Rhododendron intricatum, 260

Rhododendron japonicum, 250, 253

Rhododendron Jacksonii, 266

Rhododendron Kaempferi, 255

Rhododendron King of the Purples, $26 \mathrm{r}$

Rhododendron Lady Armstrong, 26r

Rhododendron laetevirens, 250 \%

Rhododendron lapponicum, 257, 258

Rhododendron ledifolium, 256

Rhododendron luteum, 250, 253, 254

Rhododendron Madame Carvalho, 26r

Rhododendron maximum, 264, 266, 269, 270

Rhododendron Metternichii, 269

Rhododendron micranthum, 260

Rbododendron minus, 257,258

Rhododendron Mrs. Charles Sargent, 26r

Rhododendron Mrs. H. H. Hunnewell, 26r

Rhododendron Mont Blanc, 266

Rhododendron mucronulatum, 194, 259

Rhododendron myrtifolium, 258

Rhododendron nudiflorum, 251, 254

Rhododendron obtusum, 256

Rhododendron occidentale, $250,253$.

Rhododendron odoratum, 266

Rhododendron orbiculare, 273
Rbododendron oreodoxa, 973

Rhoddoendron ponticum, 246, $264,265.269$

Rhododendron poukhanense, 256

Rhododendron praecox, 259

Rhododendron punctatum, 258

Rhododendron purpureum elegans, $26 \mathrm{r}$

Rhododendron purpureum grandiflorum, $26 \mathbf{r}$

Rhododendron racemosum, 260

Rhododendron rhombicum, 256

Rhododendron roseum elegans, $26 \mathrm{r}$

Rhododendron Schlippenbachii, 257

Rhododendron sinense, 250, 253

Rhododendron Smirnowii, 260, 270, 271

Rhododendron sonomense, 250

Rhododendron strigillosum, 273

Rhododendron Ungernii, 260

Rhododendron viscosum, 252, 254

Rhododendron wellesleyanum, $27 x$

Rhododendron Wilsonii, 250

Rhododendrons, planting Lilies among, 27, 31; culture of, 245; preparations for in limestone areas, 248; in England, 264-268; natural habitat, 260

Rhodora Azaleas, 249

Rhodora canadense, 249

Rhodora Vaseyi, 249

Rhodora Vaseyi album, 250

Rhus, for ornamental fruits, 84

Rhus javanica (R. Osbeckii or R. semialata) for summer display, 45

Ribes, for ornamental fruits, 83

Rodgersia aesculifolia, 236

Rodgersia pinnata, var. alba, 236

Rodgersia sambucifolia, 236

Rosa, confines and classification of the genus, to

Rosa alba, 12

Rosa arvensis, 12

Rosea Banksiae, 6

Rosa Banksiae, var. lutea, 6, 16

Rosa Banksiae, var. lutescens, I6

Rosa bracteata, 6

Rosa Brunonii, 155

Rosa centifolia, 7, 12, 13

Rosa centifolia, var. muscosa, 12

Rosa chinensis, 4, 5, 7, 8, 12

Rosa chinensis, var. semperflorens, $4,5,7$

Rosa chinensis, var. spontanea, ro

Rosa cinnamomea, 12

Rosa damascena, 7, 12, 13

Rosa Ecae, 15

Rosa filipes, 156

Rosa foetida, 15

Rosa Fortuneana, 8

Rosa gallica, 7, Ix, I3

Rosa Gentiliana, 156,157

Rosa gigantea, 9

Rosa Helenae, 156, 157

Rosa hemisphaerica, I2, I5

Rosa Hugonis, I5

Rosa humilis, II

Rosa laevigata, 4, 6

Rosa longicuspis, 156, 157

Rosa Luciae, 8

Rosa microphylla, 7

Rosa moschata, 8, I2

Rosa multibracteata, 157

Rosa multiflora, introduced into France from Japan, 9

Rosa multiflora, var. carnea, introduced into England, 5

Rosa multiflora, var. cathayensis introduced into England from China, 4

Rosa multiflora, var. platyphylla, introduced into England from China, 5

Rosa odorata, 5,8

Rosa odorata, var. gigantea, 6, 155

Rosa odorata, var. pseudoindica, 8 
Rosa pendulina, I2

Rosa persica, 15

Rosa provencialis, 12

Rosa Roxburghii, 7, 10

Rosa Rubus 156, 157

Rosa rugosa, 6, II

Rosa setigera, II

Rosa spinosissima, 12, 16

Rosa virginiana, double flowered form, II

Rosa Willmottiae, 157

Rosa xanthina, I5

Rose American Beauty, wild prototype of, II

Rose d'Amour, double flowered form of Rosa virginiana, II

Rose Edward, 7

Rose, Moss, 12

Rose, Musk, 8, 12, 156

Rose of Sharon, for summer resorts, 39

Roses, introduced into Europe from China, 3, 4 parentage of modern varieties, 7 ; now in cultivation mostly made varieties, Ir; kinds used by hybridists, 12; varieties known to ancient writers, 12; old varieties displaced, 13; how propagated, 13; ideals in breeding, $14 ;$ new varieties desired, I5; name, Rose common to all peoples, 17 ; its place in the history of the world, I7; societies, devoted to encouraging its advancement, 17 ; new introductions, I 56

Roses, climbing organs of, 57

Roses, for ornamental fruits, 83

Roses, Wild, Lilies planted among, 31

Rouen Botanic Garden, origination of Syringa chinensis (or Syringa rothomagensis) at, 228

Rowan, for ornamental fruits, 83,87

Royal Gardens, Kew, receives first plants from China, 4; Sophora japonica thriving at, 42

Rubus, for ornamental fruits, 83

Rubus, bambusarum, r68

Rubus chroösepalus, I68

Rubus flagelliflorus, I68

Rubus Henryi, 168

Rubus ichangensis, 169

Rubus Swinhoei, I69

St. John's Wort (Hypericum patulum, var. Henryi), 50

Salix Bockii, r 70

Salix magnifica, 170

Salvia Przewalskii, 238

Sarcococca humile 166

Sarcococca ruscifolia, 166

Sargent, Prof. C. S., flowers for first time Magnolia kobus, var. borealis, 185; introduces Malus Sargentii, 2 Ir; introduces, Rhododendron Kaempferi, 255; met in Boston by $\mathrm{Mr}$. Wilson en route to China in search of Davidia, 276

Sargent, Mrs. Charles S., Lily named in honor of,

Sassafras, $84,102,107$

Sambucus, for ornamental fruits, 83

Sambucus callicarpa, 9 I

Sambucus canadensis, 94

Sambucus canadensis, var. maxima, 95

Sambucus pubens, 95

Sambucus pubens, var. leucocarpa, 95

Sambucus racemosa, 91

Scale insects, to control, $203,2 \mathrm{I} 2$

Schizophragma hydrangeoides, 68

Sciadopitys verticillata, 126

Sea Buckthorn (Hippophae rhamnoides), 88

Senecio clivorum, 233

Senecio tanguticus, 234

Senecio Veitchianus, 233

Senecio Wilsonianus, 233, 234

"Seven Sisters" Rose (Rosa multiflora, var. platyphylla), 5,9
Shadbush, 107

Sheep Laurel, 142

Shepherdia canadensis, 88

Shisandra chinensis, 64

Siberian Moonseed (Menispermum dauricum), 75

Silky Cornel (Cornus Amonum), 98

Silver Maple, ro6

Sinomenium acutum, 75

Slater, Gilbert, obtains first Crimson China Monthly Rose in England, 5

Smilax, climbing organs of, 56

Smilax hispida, 75

Smilax rotundifolia, 75

Smilax Sieboldii, 75

Smith, Prof. R. sends from Japan to England

"the Engineer" Rose, 8

Smoketree (Cotinus), ro7

Snowberry, Creeping, 150

Snowberry Bush (symphoricarpos), 09

Snowberries, for ornamental fruits, 83

Snowy Mespilus, 107

Sophora japonica, for summer display, $4 \mathrm{I}$; introduced into France from China by Father d'Incarville, 42

Sorbaria Aitchisonii, 48

Sorbaria arborea, 48

Sorbaria assurgens, 48

Sorbaria Lindleyana, 49

Sorbaria sorbifolia, 48

Sorbaria stellipili, 48

Sorbarias for summer display, 47

Sorbus, for ornamental fruits, 83

Sorbus americana, 87

Sorbus Aucuparia, 87

Sorbus decora, 87

Sourwood or Sorrel Tree, 40 , 106

Spicebush (Benzoin aestivale), $84,110,180$

Spindle-tree, for ornamental fruits, 83

Spondias axillaris, 173

Spraying solutions for scale insects, 203, 212

Spruce, Canadian, or White, 121

Spruce, Colorado Blue (Picea pungens), I I9

Spruce, Engelmann's, 12 I

Spruce, Norway, 120

Spruce, Oriental, 122

Spruce, Serbian, 121

Stachyuras chinensis, I70

Staphylea holocarpa, I 7 I

Staphylea holocarpa, var. rosea, 172

Stewartia pentagyna, summer flowering native, 45

Stewartia pseudocamellia, for summer display, 44

Stranvaesia Davidiana, r6r

Stranvaesia Davidiana, var. undulata, I6I

Sumach, 84, 106, 107, 110

Summer Lilac, 52

Summer gardens, shrubs suitable for, 39

Summer Grape (Vitis aestivalis), 72, 73

Supple-Jack (Berchemia scandens), 65

Sweet, introducer of Fairy Rose, 7

Sweet Bay (Magnolia glauca) for summer display, 40

Sycopsis sinensis, 167

Symplocos crataegoides, 97

Symplocos paniculata, 84,98

Symphoricarpos, for ornamental fruits, 83

Symphoricarpos mollis, 99

Symphoricarpos orbiculatus, 99

Symphoricarpos racemosus, 99

Symphoricarpos racemosus, var. laevigatus, 99

Syringa affinis, 215, 219

Syringa affinis, var., Giraldii, 210

Syringa alborosea, 223

Syringa amurensis, 226

Syringa chinensis, 228

Syringa chinensis alba, 229

Syringa emodi, 215, 225 
Syringa Henryi, 228

Syringa Henryi Lutece, 228

Syringa byacinthiflora, 220

Syringa japonica, 21 5, 227

Syringa Josikaea, 214, 224, 228

Syringa Julianae, 222

Syringa oblata, 21 5, 219, 220, 229

Syringa pekinensis, 226

Syringa persica, 221, 228

Syringa persica, var. alba, 221

Syringa persica, var. laciniata, 221

Syringa pinnatifolia, $22 \mathrm{I}$

Syringa pubescens, 220

Syringa reflexa, 221

Syringa Rehderiana, 223

Syringa rothomagensis, 228

Syringa Sweginzowii, 225

Syringa tomentella, 223

Syringa villosa, 223, 228

Syringa vulgaris, $2 \mathrm{I} 3,2 \mathrm{I} 4,228,229$

Syringa Wilsonii, 223

Syringa Wolfii, 224

Tamarack or Hackmatack, $x 34$

Taxodium, II3

Taxus baccata. 136

Taxus canadensis, 136

Taxus cuspidata, 136

Taxus cuspidata, var. nana, 137

Tecoma radicans. 67

Tecoma radicans. var. praecox, 67

Thalictrum dipterocarpum, 238

Thayer, Mrs. Bayard, Lily named in honor of, 29

Thea cuspidata, 164

Thuja gigantea, 127

Thuja occidentalis, 128

Thuja occidentalis Little Gem, I33

Thuja occidentalis, var. lutea, 129

Thuja occidentalis, var. pendula, 129

Thuja occidentalis, var. plicata, 127, 129

Thuja occidentalis, var. plicata argenteo-variegata, 120

Thuja occidentalis recurva nana, I33

Thuja occidentalis Reedii, 133

Thuja occidentalis Tom Thumb, 133

Thuja occidentalis umbraculifera, I33

Thuja occidentalis, var. Vervaeneana, 128

Thuja occidentalis, var. Wareana, 129

Thuja occidentalis, var. Wareana aurea, I29

Thuja occidentalis Woodwardii, 133

Thuja orientalis, 129

Tiger Lily (Lilium tigrinum), 20, 25

Tokyo, Plum Gardens of, 187

Trailing Arbutus, 148

Tree of Heaven (Ailanthus), 172

Trellises for climbing plants, 58

Tripterygium Regelii, 64

Trumpet-flower (Campsis radicans, or Tecoma radicans), 67

Trumpet-flower, climbing organs of, 57

Tsuga canadensis, II4, 122

Tsuga canadensis, var. compacta, 122

Tsuga canadensis, var. microphylla, 123

Tsuga canadensis, var. pendula, 123

Tsuga canadensis, var. Sargentiana, 122

Tsutsutsi Azaleas, 240

Tulip-tree, 102, 106, 107

Tupelo (Nyssa sylvatica), 84, 106, 108

Turner, Messrs. Chas., purchase stock of "The Engineer" Rose and change name to "Crimson Rambler," 9

Ulmus americana, 176

Umbellate Lily, type of the group, 25

Ume (Japanese Apricot), 187

Under-tree planting, shrubs for, I 66
Vaccinium, for ornamental fruits, 84

Vaccinium Vitis-idaea, 148

Vacciriums, planting Lilies among, 31

Van Houtte, first to produce double Rhododendron luteum, 254

Varnish Tree (Köelreuteria paniculata), for summer display, $4 \mathrm{X}$

Veitch, John Gould, first to send Lilium auratum to England, 21

Veitch. Messrs., first in England to flower Lilium auratum, 2I; receive first seeds of Giant Arborvitae (Thuja plicata), in England, 127; send E. W. Wilson in search of the Davidia, 275

Veronica angustifolia, 53

Veronicas, planting Lilies among, 3 I

Viburnum, 106, Iro

Viburnum acerifolium, 95

Viburnum alnifolium, 95

Viburnum americanum, $9 \mathrm{r}$

Viburnum buddleifolium, $\mathbf{I}_{3}$

Viburnum Canbyi, 97

Viburnum cassinoides, 97

Viburnum coriaceum, I62

Viburnum Davidii, I6r

Viburnum dentatum, 97

Viburnum dilitatum, or

Viburnum furcatum, 95

Viburnum Harryanum, 162

Viburnum Henryi, r6I

Viburnum Lantana, 95

Viburnum lantanoides, 95

Viburnum lentago, 97

Viburnum Opulus, $9 \mathrm{r}$

Viburnum Opulus, var. xanthocarpum, 92

Viburnum plicatum, 95

Viburnum propinquum, 162

Viburnum prunifolium, 97

Viburnum pubescens, 95

Viburnum rhytidophyllum, $95,16_{2}$

Viburnum rufidulum, 97

Viburnum Sargentii, 91

Viburnum Sieboldii, 95

Viburnum tomentosum, 95

Viburnum utile, 162

Viburnum Veitchii, 95

Viburnum Wrightï, 9 I

Viburnums, for fruits and flowers, 79, 83

Vilmorin, Maurice de, raises first tree of Davidia involucrata in Europe, 294

Vinca minor, 147

Virginia Creeper, 106, 107, 110

Vitis aestivalis, 72

Vitis amurensis, $7 \mathbf{I}$

Vitis armata, $7 \mathbf{I}$

Vitis betulifolia, 72

Vitis bicolor, 72

Vitis cinerea, 72

Vitis Coignetiae, 70

Vitis cordifolia, 73

Vitis Davidii, 71

Vitis Davidii, var. cyanocarpa, 71

Vitis Doaniana, 72

Vitis flexuosa, var. parvifolia, 72

Vitis flexuosa, var. Wilsonii, 72

Vitis labrusca, 73

Vitis Piasezkii, 72

Vitis pentagona, 72

Vitis reticulata, 72

Vitis Romanetii, 72

Vitis rupestris, 73

Vitis, climbing organs of, 56

Von Siebold, Philip Franz, introduces Prunus subhirtella, var. pendula, into Holland, 199 introduces Malus floribunda into Holland, 207; introduces Malus Sieboldii, 208; distributes Malus ringo, 2 ro 
Walnut, ro6

Washington, George, plants Lilac at Mount Vernon, 214

Washington Thorn, for ornamental fruits; 85

Waterer, hybridizer of Rhododendrons, 268

Wayfaring Tree (Viburnum Lantana), 95

Waxwork (Celastrus scandens), 65,83

Weld, Gen. Stephen M., Primula pulverulenta in garden of, 240

Wichuraiana Rose (Rosa Luciae), introduced into Belgium from Japan, 8; wild prototype of, $\mathbf{I}$

Wild Roses, extolled in poetry and prose for centuries, 16; Lilies planted among, 31; for fruits and flowers, 79; in autumn colors, ro6

Williams, S. T., introduces Syringa affinis into Arnold Arboretum from Japan, 219

Willock, Sir Henry, introduces Yellow Persian Rose, 15

Willow, ro5

Willows, new introductions, 170

Wintergreen, or Checkerberry, 149

Wistar, Dr. Caspar, Wistaria named in honor of, by Nuttall, 60

Wistaria, 56

Wistaria, how named, 60
Wistaria, Chinese, 60

Wistaria, Japanese, remarkable for long racemes of flowers, $6 \mathrm{r}$; when and by whom introduced to Europe and America, 62; how propagated, 63

Wistaria floribunda, var. macrobotrys, 6 I

Wistaria frutescens, 60

Wistaria multijuga, 6r

Wistaria sinensis, introduced into England from China, 60

Witch Hazels (Hamamelis), 177

Woodbines (Lonicera Periclymenum), 66

Xylosma racemosum, 173

Xylosma racemosum, var. pubescens, 173

Yellow flowered shrubs, 49

Yellow and orange fruited shrubs, 92

Yew, 136

Yew, English, 136

Yew, Japanese, $\mathbf{1}_{3} 6$

Yoshino-sakura, Japanese Flowering Cherry, 200

Yucca filamentosa, 49, 147

Yucca flaccida, 49,147

Yucca glauca, 49, 147

Yulan (Magnolia conspicua), I8a 



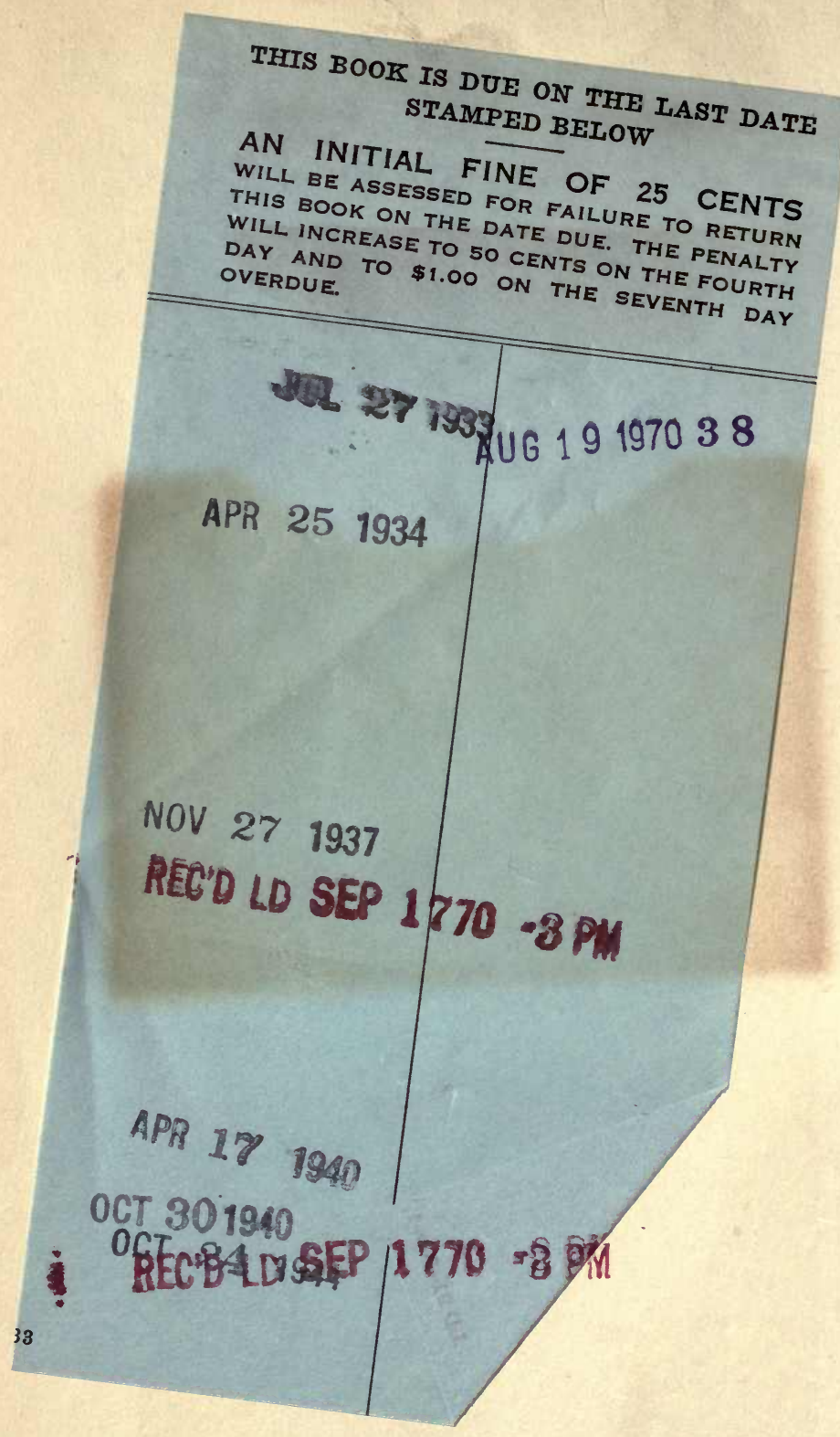




\section{5}

\section{$5 B+53$ W5 5}

\section{UNIVERSITY OF CALIFORNIA LIBRARY}




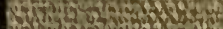

4.

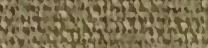

Hin 325

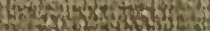

hos.

whe

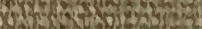

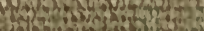

$5342430 \mathrm{~m}$

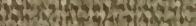

2.

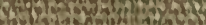

How

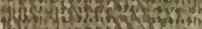

$42 \times 33460$

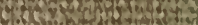

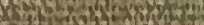

4.

$24035,2 y$

(1)

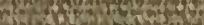

tos

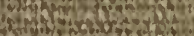

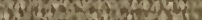

Mremexan

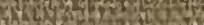

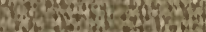

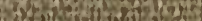

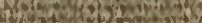

21020 .

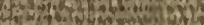

49. 2 .

1.

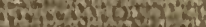

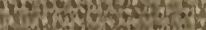

ring 20 m

Nes hat

X.

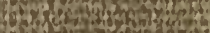

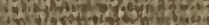

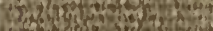

427 ,

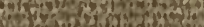

1602 ar

22040925

1.

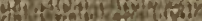

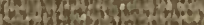

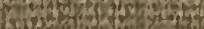

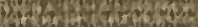

han

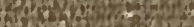

(n) 340

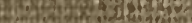

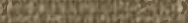

(79.2.

and

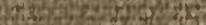

(2)

1.5 35 ,

$-350$

and

17202

.

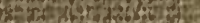

roo

4. 4 th

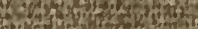

$74+25057 \%$

(2).

7.

(1)

2.

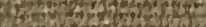

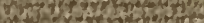

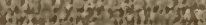

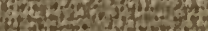

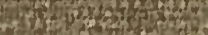

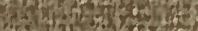

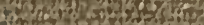

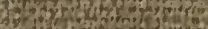

Fis.

24atrans?

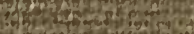

1. 401 y

4.

2.

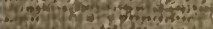

act

243

Q⿻

-

Whathe

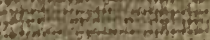

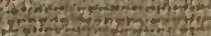

